ROSELI DA SILVEIRA

\title{
Estudo sociogeolingüístico do município de Iguape: aspectos semântico-lexicais
}

Dissertação apresentada ao Curso de Pós-Graduação em Linguiística do Departamento de Lingüística da Faculdade de Filosofia, Letras e Ciências Humanas da Universidade de São Paulo como exigência para obtenção do título de Mestre em Lingüística.

Área de Concentração: Semiótica e Lingüística Geral

Orientadora: Prof ${ }^{\mathrm{a}} . \mathrm{Dr}^{\mathrm{a}}$. Irenilde Pereira dos Santos 


\section{FOLHA DE APROVAÇÃO}

Roseli da Silveira

Estudo sociogeolingüístico do município de Iguape: aspectos semântico-lexicais

Dissertação apresentada ao Curso de Pós-Graduação em Lingüística do Departamento de Lingüística da Faculdade de Filosofia, Letras e Ciências Humanas da Universidade de São Paulo como exigência para obtenção do título de Mestre em Lingüística.

Área de Concentração: Semiótica e Lingüística Geral

Aprovada em:

Banca Examinadora

$\operatorname{Prof}\left({ }^{\mathrm{a}}\right) \operatorname{Dr}\left({ }^{(a)}\right.$

Instituição: Assinatura:

$\operatorname{Prof}\left({ }^{a}\right) \operatorname{Dr}\left({ }^{(a}\right)$

Instituição: Assinatura:

$\operatorname{Prof}\left({ }^{a}\right) \operatorname{Dr}\left({ }^{(a}\right)$

Instituição: Assinatura: 


\section{DEDICATÓRIA}

A meus filhos Fábio, Felipe e Ricardo.

A Florival Caceres, pesquisador da História do Brasil - foi quem me apresentou Iguape -, pelos bons e maus momentos que partilhamos. 


\section{AGRADECIMENTOS}

O desafio a que nos propusemos ao retomar a vida acadêmica, depois de toda uma vida profissional dedicada à educação de jovens e adultos de escolas públicas, não deixou de ser uma forma de me manter próxima dos livros, dos colegas, do ambiente escolar.

A volta aos bancos escolares, às pesquisas na biblioteca, a ida a simpósios e congressos, fizeram renascer o gosto pelo conhecimento, pela descoberta, pelo saber. E quanto ainda tínhamos e temos a aprender!

Esta etapa está praticamente concluída. Tentamos desincumbirmo-nos da melhor maneira possível, mas, como seres humanos imperfeitos que somos, certamente neste trabalho cometemos falhas, deixamos lacunas.

Humildemente agradecemos ao leitor criterioso, em nome da pesquisa e da Ciência, que, fazendo parte ou não de nossa Banca Examinadora, venha trazer contribuições para esclarecimento de pontos que ficaram obscuros.

Muitas foram as pessoas que nos ajudaram a levar adiante nosso projeto. Sem elas, sem dúvida teríamos dificuldades em levar a bom termo a empreitada. A todas agradeço de coração.

Aos familiares agradecemos principalmente pela paciência e compreensão; ao irmão Geraldo, à Cida e Martim, pela colaboração. À mãe, Yara, e irmãs, Maria Tereza e Maria Cristina, agradecemos por nos acompanharem a Iguape, uma de cada vez. E ao Ricardo, por ter ido conosco de outra vez.

À colega e amiga Vilma, que me acolheu diversas vezes em sua casa e com a qual trocamos idéias sobre projetos e monografias. Aos amigos de Iguape, Gilberto e Clara, que nos receberam em sua casa e colocaram à nossa disposição o material que tinham sobre a região.

Ao Sr. Benedito Machado, iguapense apaixonado, jornalista formado em Filosofia na USP na década de 60. Pelo bate-papo no fim da tarde, na porta de sua casa em Iguape, e pelas indicações de sujeitos de acordo com o perfil requerido.

Aos colegas do Grupo de Pesquisa em Dialetologia e Geolingüística da USP, o Clézio, a Maitê, a Adriana e a Márcia. Principalmente as duas últimas citadas, pela generosidade, apoio e experiências trocadas. E às novas colegas Vera Lúcia, Yuko e Cássia. 
Às funcionárias da biblioteca da UNIBR, em São Vicente, que nos receberam sempre muito bem e pouparam idas e vindas a São Paulo, para consulta aos livros de que precisávamos.

A todos os professores e funcionários do Departamento de Lingüística, sempre muito prestativos, e aos funcionários da Administração da FFLCH.

Agradecemos, por fim, às Professoras Doutoras Maria Vicentina do Amaral Dick e Adriana Cristina Cristianini pelas contribuições valiosas quando da participação das mesmas em nossa Banca de Exame de Qualificação. E à Prof ${ }^{a}$ Dr $^{a}$ Ana Maria Marangoni, pela ajuda com os mapas para a elaboração dos cartogramas. 


\section{AGRADECIMENTO ESPECIAL}

Como não poderia deixar de ser, agradecemos especialmente a nossa orientadora Prof $^{\mathrm{a}}$. Dr ${ }^{\mathrm{a}}$. Irenilde Pereira dos Santos.

Não por seu conhecimento stricto sensu, pela sua bagagem cultural e pela experiência de vida, imensos, que ela colocou generosamente a nossa disposição.

Nem pela competência acumulada em muitos anos e seguidas vezes comprovada na orientação de alunos de pós-graduação.

Nem pela sua dedicação, organização e feeling para saber o momento exato para iniciar os procedimentos de cada etapa da empreitada.

Não pela amizade, pelo carinho e pela intimidade que nos autorizou a compartilhar.

Por tudo isso, somos imensamente gratas. Mas principalmente agradecemos pela determinação em nos conduzir a esse patamar de conhecimento, pela firmeza nas horas decisivas e pela calma e paciência nos momentos mais delicados.

Se assim ela não fosse, educadora e pessoa centrada que é, não teríamos atingido nosso objetivo. Obrigada, mais uma vez.

Por último, agradecemos ao Conselho Nacional para o Desenvolvimento da Pesquisa CNPq. Sem o incentivo financeiro do Conselho, seria difícil empreender as várias viagens que fizemos a Iguape, por vários dias, arcando com os custos de hospedagem, alimentação e despesas com locomoção.

A Bolsa-auxílio deu tranqüilidade à pesquisadora para que ela se concentrasse apenas em seu propósito. 


\section{RESUMO}

Silveira, R. Estudo sociogeolingüístico do município de Iguape: aspectos semânticolexicais. 2009. 188 f. Dissertação (Mestrado) - Faculdade de Filosofia, Letras e Ciências Humanas da Universidade de São Paulo, 2009.

Iguape é um dos municípios do litoral sul paulista que teve muita importância na história do Brasil Colonial. Conheceu o auge com o ciclo do arroz, quando o rio Ribeira de Iguape era o principal meio de transporte e o porto às suas margens um dos mais importantes do País. Depois veio o declínio, consequiência da abertura do Valo Grande e do assoreamento de seu porto. E, por fim, veio o isolamento numa das regiões mais pobres do Estado de São Paulo, o Vale do Ribeira. Iguape é o ponto 334 indicado por Antenor Nascentes para a pesquisa da realidade dialetal brasileira. $\mathrm{O}$ presente estudo objetiva registrar amostras desse verdadeiro "dialeto caiçara", bolsão de tupinismos, arcaísmos e variantes lexicais peculiares. Procurou-se arrolar as lexias mais utilizadas na região não somente para lançá-las num mapa. Além de fazer o tratamento quantitativo dos dados, com o apoio das noções de estatística lexical de Muller, privilegiou-se a abordagem dos aspectos semântico-lexicais, com base em Pottier e Rastier, partindo da concepção de norma de Coseriu. Com base nos procedimentos teóricometodológicos da Geolingüística da atualidade, aplicaram-se as questões da área "Corpo Humano" do Questionário semântico-lexical do Projeto ALiB, versão 2001, em três pontos do município de Iguape - Icapara, Rocio e Jairê, a doze sujeitos, quatro de cada ponto, dos dois gêneros e em duas faixas etárias, quais sejam, de 18 a 30 anos (primeira faixa) e de 66 anos em diante (segunda faixa). A partir das respostas obtidas nas entrevistas, elaboraram-se dezesseis cartogramas, que espelham a variação diatópica de cunho lexical. Ainda em consonância com os preceitos da Geolingüística moderna, que alia sua metodologia às da Sociolingüística, compondo um quadro pluridimensional, mostrou-se o quadro da diversidade linguiística local. Em suma, o trabalho faz o registro da realidade lingüística desta parte muito pequena do Brasil, mas de grande importância para os estudos geolingüísticos, antes que esses falares se percam, quer pela ação homogeneizadora dos meios de comunicação de massa, quer pelas próprias forças centrífugas da língua.

Palavras-chave: Geolinguíística. Iguape. Dialeto. Variante lexical. Norma. 


\begin{abstract}
Silveira, R. Sociogeolinguistics study of the city of Iguape: semantic-lexical aspects. 2009. 188 f. Dissertation (Masters in Linguistics) - Faculdade de Filosofia, Letras e Ciências Humanas da Universidade de São Paulo, 2009.
\end{abstract}

Iguape is one of the cities on the southern coast of São Paulo State that had great importance in the History of colonial Brazil. It had its days of glory during the rice plantation period, when Ribeira de Iguape River was the main means of transportation and the port on its banks was one of the most important in the country. Later, decline came as a consequence of the opening of Valo Grande and the aggradation of its port. Finally, it became isolated in one of the poorest areas of the São Paulo State, the Ribeira Valley. Iguape is point number 334, as indicated by Antenor Nascentes, for the research of the Brazilian dialectal reality. The present work aims at registering samples of this truly "caiçara" dialect, in a region of "tupinisms", archaisms and peculiar lexical variants. We intended not only to place the lexias used in the area on a map, but also to list the most frequent ones. Besides doing quantitative treatment to data, based on Muller's notions of Lexical Statistics, we have focused in approaching the semantic-lexical aspects, based on Pottier and Rastier and starting from Coseriu's notion of norm. Based on present Geolinguistics theoretical-methodological procedures, we have applied the questions from area "Human Body" in the semantic-lexical Questionnaire of Project AliB, version 2001, in three points of the city of Iguape - namely Icapara, Rocio e Jairê -, to twelve subjects, four in each point, from both genders and belonging to two age groups, between 18 to 30 (first group) and older than 66 (second group). From the answers obtained in interviews, we have elaborated sixteen cartograms, which reflect the diatopic variation on lexical basis. Still in consonance with the principles of modern Geolinguistics, which allies its methodology to the one used in Sociolinguistics, forming a pluridimensional framework, we have showed the picture of local linguistic diversity. In summary, this work registers the linguistic reality of this very small part of Brazil, which has great importance to geolinguistic studies, before the loss of these speeches, be it by the homogenizing effect of mass media or by language's own centrifugal forces.

Keywords: Geolinguistics. Iguape. Dialect. Lexical variants. Norm. 


\section{LISTA DE QUADROS}

Quadro 1 - Determinação de pontos e número de sujeitos 041

Quadro 2 - Representação dos sujeitos nos cartogramas ..............................................................042

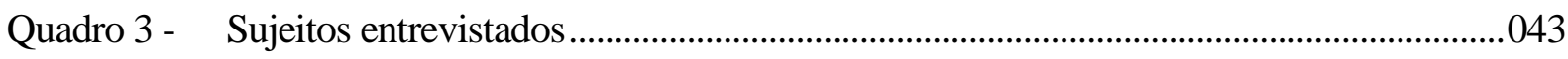

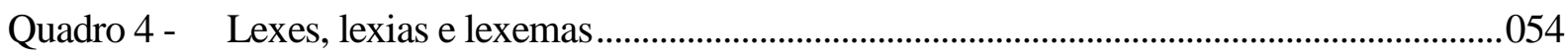

Quadro 5 - Lexia com 100\% de freqüência .................................................................................... 140

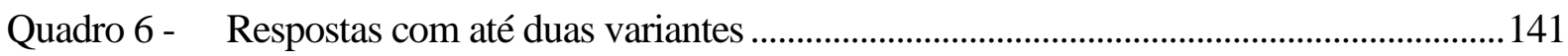

Quadro 7 - Respostas com três ou mais variantes .........................................................................141

Quadro 8 - Norma semântico-lexical de Iguape ……....................................................................... 141

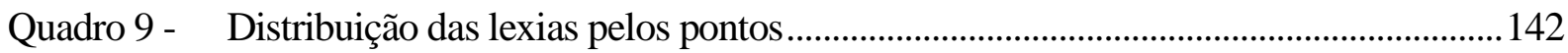

Quadro 10 - Comparação sexo/gênero x uso de termo especializado .................................................. 143

Quadro 11 - Comparação faixa etária x uso de termo especializado ................................................... 143

Quadro 12 - Comparação Iguape com outros atlas........................................................................... 143

Quadro 13 - Lexias compostas de semas inerentes e aferentes ....................................................... 144

Quadro 14 - Semas inerentes de terçol e viúva ................................................................................. 145

Quadro 15 - Semas aferentes comuns a terçol e viúva ${ }^{2}$..................................................................... 145

Quadro 16 - Sememas de catarata: semas inerentes e aferentes..................................................... 145

Quadro 17 - Sememas de tatu: semas inerentes e aferentes............................................................... 146

Quadro 18 - Sememas de pomo-de-adão: semas inerentes e aferentes .............................................146 


\section{LISTA DE TABELAS}

Tabela 1 - Freqüência geral da questão 89 - Iguape.....................................................................062

Tabela 2 - Freqüência da questão 89 por sexo/gênero ........................................................................063

Tabela 3 - Frequiência da questão 89 por faixa etária..........................................................................064

Tabela 4 - Distribuição das lexias da questão 89 pelos pontos .........................................................064

Tabela 5 - Comparação da variação lexical da questão 89: Iguape - Outros atlas regionais ......065

Tabela 6 - Freqüência geral da questão 90 - Iguape .......................................................................068

Tabela 7 - Freqüência da questão 90 por sexo/gênero .......................................................................069

Tabela 8 - Freqüência da questão 90 por faixa etária........................................................................069

Tabela 9 - Distribuição das lexias da questão 90 pelos pontos ........................................................069

Tabela 10 - Comparação da variação lexical da questão 90: Iguape - Outros atlas regionais .......070

Tabela 11 - Freqüência geral da questão 91- Iguape.....................................................................073

Tabela 12 - Freqüência da questão 91 por sexo/gênero .......................................................................074

Tabela 13 - Frequiência da questão 91 por faixa etária........................................................................074

Tabela 14 - Distribuição das lexias da questão 91 pelos pontos ..........................................................074

Tabela 15 - Comparação da variação lexical da questão 91: Iguape - Outros atlas regionais ......075

Tabela 16 - Freqüência geral da questão 92- Iguape..................................................................078

Tabela 17 - Freqüência da questão 92 por sexo/gênero ...................................................................078

Tabela 18 - Freqüência da questão 92 por faixa etária.........................................................................079

Tabela 19 - Distribuição das lexias da questão 92 pelos pontos ........................................................079

Tabela 20 - Comparação da variação lexical da questão 92: Iguape - Outros atlas regionais ......080

Tabela 21 - Freqüência geral da questão 93- Iguape ..........................................................................083

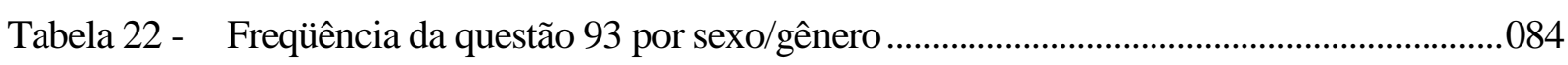

Tabela 23 - Freqüência da questão 93 por faixa etária..................................................................084

Tabela 24 - Distribuição das lexias da questão 93 pelos pontos .......................................................085 
Tabela 25 - Freqüência geral da questão 94- Iguape .088

Tabela 26 - Freqüência da questão 94 por sexo/gênero .088

Tabela 27 - Frequiência da questão 94 por faixa etária .089

Tabela 28 - Distribuição das lexias da questão 94 pelos pontos .089

Tabela 29 - Comparação da variação lexical da questão 94: Iguape - Outros atlas regionais 090

Tabela 30 - Freqüência geral da questão 95- Iguape .094

Tabela 31 - Freqüência da questão 95 por sexo/gênero .095

Tabela 32 - Freqüência da questão 95 por faixa etária

Tabela 33 - Distribuição das lexias da questão 95 pelos pontos 096

Tabela 34 - Comparação da variação lexical da questão 95: Iguape - Outros atlas regionais 096

Tabela 35 - Frequiência geral da questão 96- Iguape .099

Tabela 36 - Freqüência da questão 96 por sexo/gênero 100

Tabela 37 - Frequiência da questão 96 por faixa etária 100

Tabela 38 - Distribuição das lexias da questão 96 pelos pontos 101

Tabela 39 - Freqüência geral da questão 97- Iguape 105

Tabela 40 - Freqüência da questão 97 por sexo/gênero 106

Tabela 41 - Frequiência da questão 97 por faixa etária 106

Tabela 42 - Distribuição das lexias da questão 97 pelos pontos 106

Tabela 43 - Freqüência geral da questão 98- Iguape 109

Tabela 44 - Freqüência da questão 98 por sexo/gênero 109

Tabela 45 - Freqüência da questão 98 por faixa etária 110

Tabela 46 - Distribuição das lexias da questão 98 pelos pontos 110

Tabela 47 - Comparação da variação lexical da questão 98: Iguape - Outros atlas regionais .......110

Tabela 48 - Freqüência geral da questão 99- Iguape 112

Tabela 49 - Freqüência da questão 99 por sexo/gênero 113 
Tabela 50 - Frequiência da questão 99 por faixa etária

Tabela 51 - Distribuição das lexias da questão 99 pelos pontos

Tabela 52 - Frequiência geral da questão 100- Iguape

Tabela 53 - Freqüência da questão 100 por sexo/gênero 116

Tabela 54 - Freqüência da questão 100 por faixa etária 116

Tabela 55 - Distribuição das lexias da questão 100 pelos pontos 116

Tabela 56 - Comparação da variação lexical da questão 100: Iguape - Outros atlas regionais ....117

Tabela 57 - Frequiência geral da questão 101- Iguape

Tabela 58 - Freqüência da questão 101 por sexo/gênero

Tabela 59 - Freqüência da questão 101 por faixa etária

Tabela 60 - Distribuição das lexias da questão 101 pelos pontos

Tabela 61 - Freqüência geral da questão 102- Iguape.

Tabela 62 - Frequiência da questão 102 por sexo/gênero

Tabela 63 - Freqüência da questão 102 por faixa etária

Tabela 64 - Distribuição das lexias da questão 102 pelos pontos

Tabela 65 - Comparação da variação lexical da questão 102: Iguape - Outros atlas regionais ....124

Tabela 66 - Frequiência geral da questão 103- Iguape. 128

Tabela 67 - Freqüência da questão 103 por sexo/gênero ..................................................................128

Tabela 68 - Freqüência da questão 103 por faixa etária......................................................................129

Tabela 69 - Distribuição das lexias da questão 103 pelos pontos 129

Tabela 70 - Comparação da variação lexical da questão 103: Iguape - Outros atlas regionais ....129

Tabela 71 - Freqüência geral da questão 105- Iguape. 134

Tabela 72 - Freqüência da questão 105 por sexo/gênero. 135

Tabela 73 - Freqüência da questão 105 por faixa etária 135

Tabela 74 - Distribuição das lexias da questão 105 pelos pontos 136 


\section{SUMÁRIO}

INTRODUÇÃO 016

1 A DIALETOLOGIA E A GEOLINGÜÍSTICA …………………................................ 021

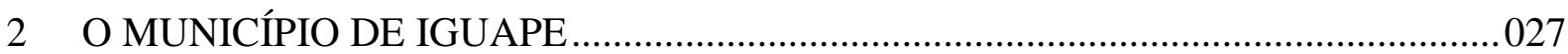

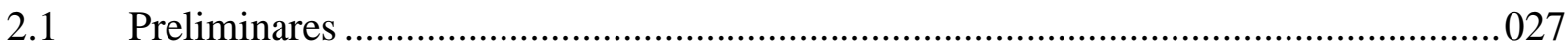

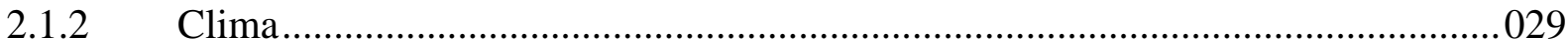

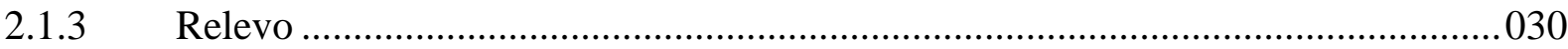

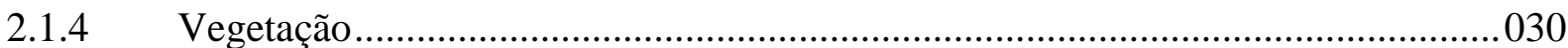

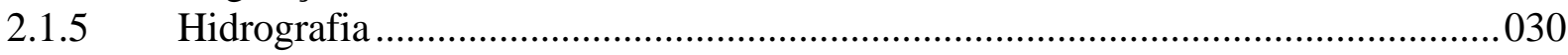

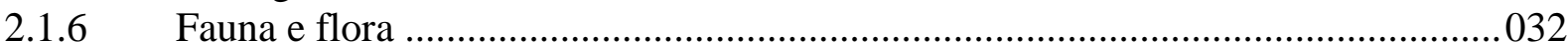

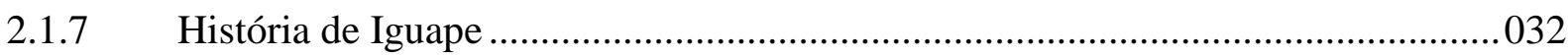

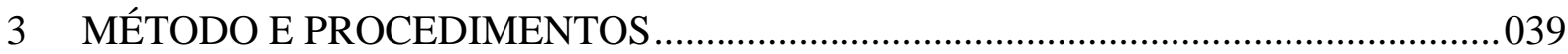

3.1 Determinação da rede de pontos e seleção dos sujeitos................................................040

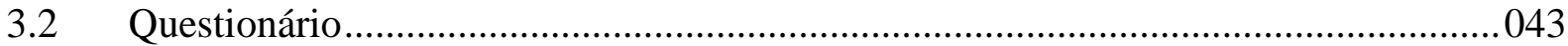

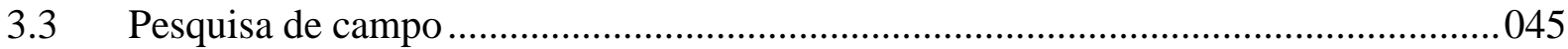

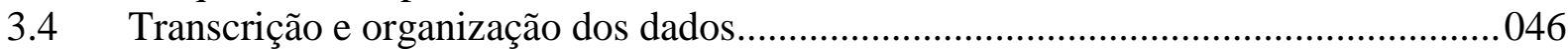

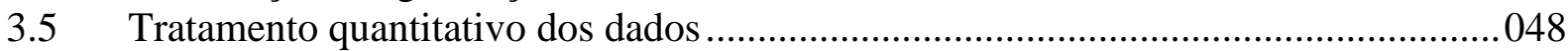

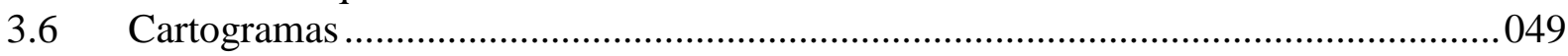

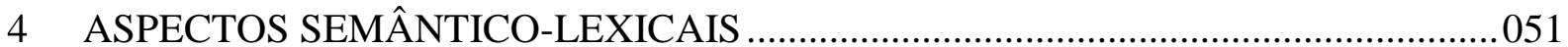

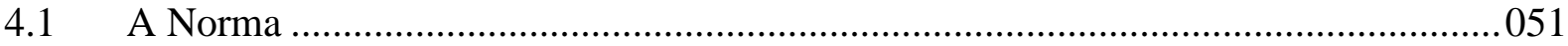

4.2 Análise de traços semânticos ................................................................................. 053

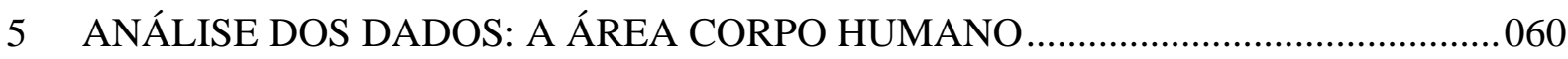

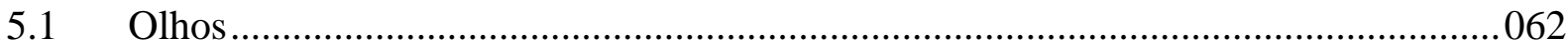

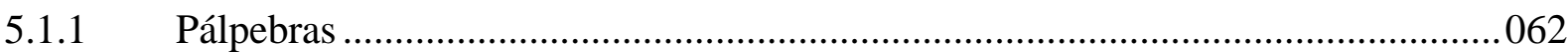

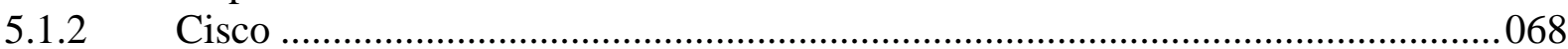

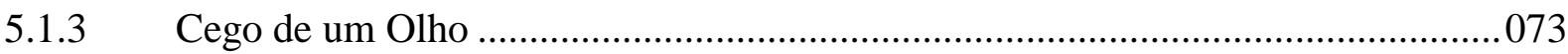

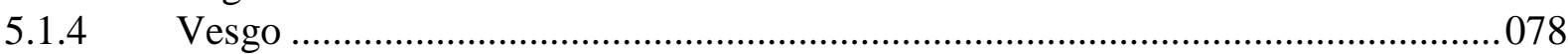

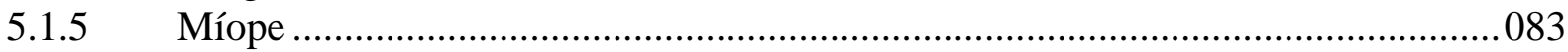

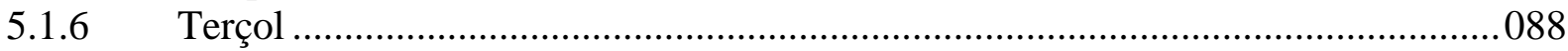

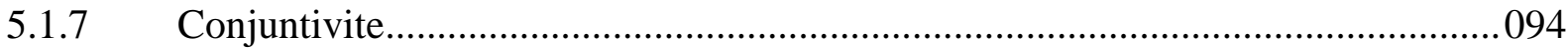

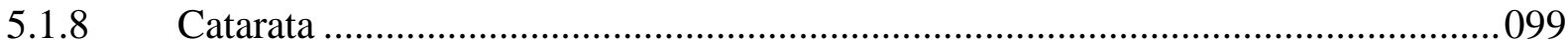

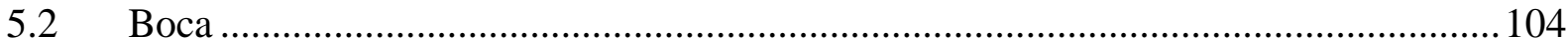

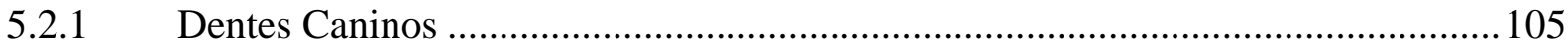

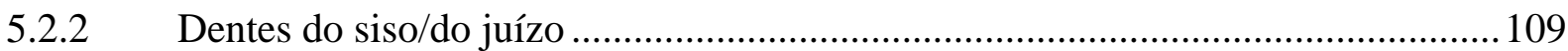

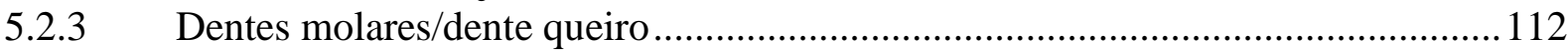

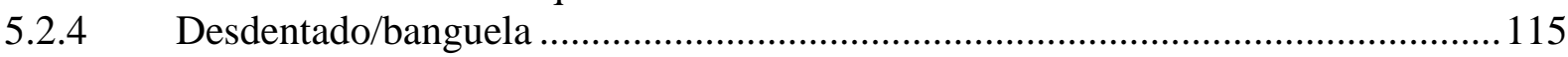

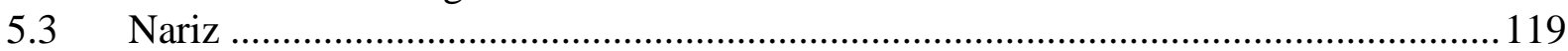

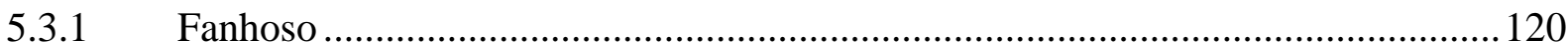

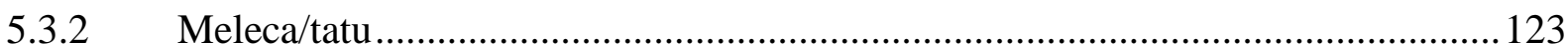

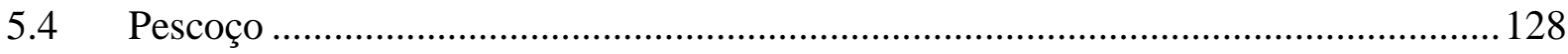

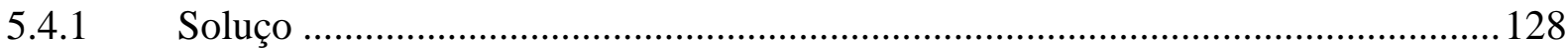

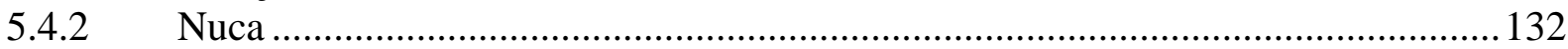

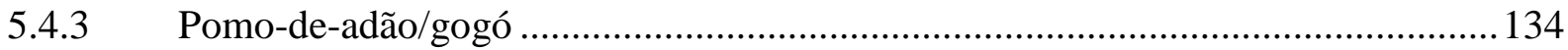




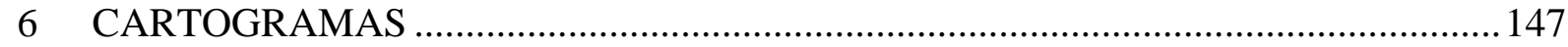

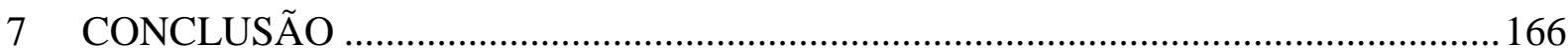

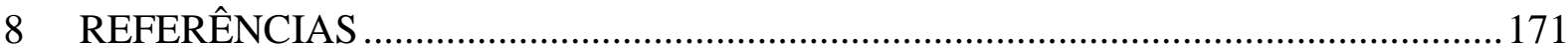

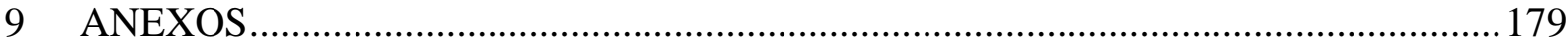


"Se não podemos impedir a flora de nossos campos de perecer em face da cultura que a substitui, devemos, antes que ela desapareça totalmente, recolher com cuidado seus espécimes, descrevê-los, dissecá-los e classificálos piedosamente num grande herbário nacional." 


\section{INTRODUÇÃO}

A unidade da língua portuguesa falada no Brasil desde há muito tem sido motivo de controvérsia entre gramáticos, filólogos e lingüistas. A maioria deles admite que há, sim, diferenças fonéticas e lexicais na nossa língua, mas que não afetam sua estrutura morfossintática. Eles acreditam que há uma unidade na diversidade.

A realidade da língua é movimento. A língua é instrumento de comunicação entre os homens, ela interpreta o mundo que o cerca; então, ela muda com o indivíduo que a utiliza para refletir essa realidade.

A língua faz parte da cultura de um povo. Ela é ao mesmo tempo geradora e produto da cultura. Por meio da língua, o indivíduo identifica-se como pertencente a uma determinada comunidade, a uma determinada cultura.

Muito embora uma comunidade lingüística tenha características próprias, seja aparentemente coesa e homogênea, a heterogeneidade está presente. Muito antes do século XIX, já se havia notado que as línguas mudam. Meillet (apud WEINREICH, 2006, p.114) acreditava na covariação da língua devido a fatores sociais:

A língua é uma instituição com autonomia própria; deve-se determinar portanto as condições gerais de desenvolvimento a partir de um ponto de vista puramente lingüístico; [...] mas como a língua é [também] uma instituição social, disso decorre que a lingüística é uma ciência social, e o único elemento variável ao qual se pode apelar a fim de explicar a mudança lingüística é a mudança social, da qual as variações lingüísticas são somente as conseqüências - às vezes imediatas e diretas e, no mais das vezes, mediata e indiretas.

As línguas naturais mudam no espaço geográfico, mudam para adaptar-se aos vários estratos sociais, mudam para refletir diferentes estilos etc. Vivem em constante mudança, para preservar sua unidade.

Os primeiros estudos dialetológicos buscavam registrar a fala de comunidades isoladas, ameaçadas de perder seu falar característico, devido ao progresso e ao crescimento das cidades. Procuravam resgatar esses falares para preservar a história da 
língua. À Dialetologia coube o papel de investigar os fenômenos da variação lingüística diatópica.

Assim também no Brasil começaram os estudos da variação dialetal. Nosso primeiro dialetólogo, Amaral (1920), indicou o caminho que deveríamos trilhar para conhecer a realidade da língua falada no Brasil. E teve vários seguidores que continuaram a pesquisa que ele iniciara em $O$ dialeto caipira.

Os estudos da variação diatópica, sob forma de monografias, dissertações de mestrado, teses de doutorado e atlas lingüísticos, regionais ou estaduais, que vêm se multiplicando nos últimos anos, têm procurado recobrir todo o território nacional, mas ainda há muito o que fazer. $\mathrm{O}$ presente estudo do falar de Iguape recai sobre um pequeno ponto dessa imensidão que é o Brasil.

Muitos fatores contribuíram para que o falar de Iguape, mais particularmente a norma semântico-lexical da localidade, apresentasse as peculiaridades que interessaram a pesquisadora e motivaram o presente trabalho. A Vila de Iguape foi fundada nos primeiros anos da colonização portuguesa no Brasil. De lá para cá, Iguape conheceu a opulência e a agitação de centro comercial e, mais tarde, a decadência e o esquecimento na região mais pobre do estado de São Paulo.

Muito antes de 1500, os índios da costa - genericamente chamados de tupis, ocupavam a faixa litorânea do Brasil, deixando na região de Iguape muitas marcas de sua cultura, como a língua, a culinária, o artesanato e provas de sua permanência no local, como os sambaquis, depósitos de cascas de ostras e siris. Os tupis conviveram com a língua portuguesa trazida pelos colonizadores portugueses desde a época do Descobrimento, sendo que por muito tempo falou-se uma língua de intercurso, chamada língua geral ou brasílica, para possibilitar a comunicação entre eles. Depois vieram os negros africanos para trabalhar nos engenhos de açúcar, os quais, submetidos à escravidão, fugiam para as matas e formavam os quilombos. Em Iguape e em toda a região do Vale do Ribeira, concentra-se considerável 
número de comunidades quilombolas. Dessa variedade de culturas e influências resultou a norma praticada pelos falantes de Iguape.

Iguape foi uma das mais importantes cidades do período colonial, passando sucessivamente por três importantes ciclos: o ciclo do ouro de mineração; o ciclo da construção naval, graças a seu porto e a sua localização privilegiada; e o ciclo do arroz, o mais importante deles, proporcionando-lhe prêmio internacional pela qualidade de seu produto. São dessa fase os casarões coloniais construídos pelos senhores da elite agrária, hoje preservados pelo Patrimônio Histórico.

No entanto, para facilitar o transporte das sacas de arroz que chegavam ao porto do Ribeira, às margens do rio Ribeira de Iguape, levadas em canoas, e de lá transportadas em lombo de burro até o porto de Iguape, e para diminuir os custos com o frete, resolveram abrir um canal de dois quilômetros de extensão, ligando o rio ao Mar Pequeno. A obra do canal do Valo Grande, como ficou conhecido, foi desastrosa para a economia de Iguape: as margens do rio Ribeira começaram a desbarrancar devido à força de suas águas, que passaram a entrar pelo canal, e essa areia foi sendo depositada em frente ao porto de Iguape, o que, aos poucos, foi impedindo a entrada de navios.

A região foi rapidamente entrando em decadência econômica e só foi recuperar sua força a partir da segunda metade do séc. XX. A partir da década de 70, os turistas descobriram suas belezas naturais e compraram muitas terras dos caiçaras. Mais recentemente, Iguape recebeu investimentos na área do turismo (ecológico e religioso, principalmente), que é considerado, atualmente, a base de sua economia.

Iguape conserva muitas tradições. A própria religiosidade, que leva milhares de romeiros vindos de todas as partes do estado de São Paulo e do Paraná à Festa do Bom Jesus de Iguape, a Festa de Agosto, é herança de seus antepassados, portugueses e espanhóis, que o caiçara preservou. Bairros como os de Icapara, Jairê e Barra do Ribeira, apresentam 
arraigadas tradições caiçaras; o Morro Seco já é formado, em sua maioria, por descendentes dos quilombolas. Por outro lado, os moradores do centro da cidade e do Rocio vão perdendo aos poucos seus costumes, seu modo de falar. Por isso é importante registrar, nesse momento, as manifestações lingüísticas espontâneas dessa comunidade lingüística.

Dessa forma, esta dissertação tem por objetivo geral registrar a variação dialetal do léxico e investigar alguns aspectos semântico-lexicais dessas realizações, fazendo a relação entre o que é norma na região com a história sócio-político-cultural da comunidade. Dada a amplitude do universo semântico-lexical, ater-nos-emos às questões da área "Corpo Humano", do questionário do Projeto ALiB. Nossos objetivos específicos são:

- Dar tratamento quantitativo aos dados coletados;

- Registrar a norma semântico-lexical de parte do falar de Iguape;

- Analisar aspectos semântico-lexicais dos dados coletados;

- Apresentar, sob forma de cartogramas ilustrativos, a variação diatópica;

- Colaborar para o conhecimento da diversidade da língua falada no estado de São Paulo e no Brasil.

- Colaborar para a elaboração de glossários e dicionários, ampliando o campo das informações;

- Contribuir para os estudos da língua portuguesa falada no Brasil, principalmente no tocante a seu aspecto multidialetal.

Com o fim de alcançar estes objetivos, estruturamos nossa dissertação da seguinte maneira:

$\mathrm{Na}$ Introdução, apresentamos a justificativa, a perspectiva da análise e os objetivos da pesquisa.

No capítulo 1, Dialetologia e Geolingüística, fizemos um histórico dos primeiros estudos dialetológicos, apresentamos a Geolingüística, o método da Dialetologia, delimitamos 
seu campo de trabalho, acompanhamos seu percurso teórico e falamos sobre o método que baliza este estudo.

O capítulo 2, O município de Iguape, traça o perfil de Iguape, a localidade pesquisada, desde suas características geográficas, sua história econômica e social, até sua situação na atualidade.

No capítulo 3, Método e procedimentos, explicamos as etapas do método geolingüístico, apropriado para este tipo de pesquisa. Incluem-se, no capítulo, a delimitação da rede de pontos, a escolha dos sujeitos, o questionário a ser aplicado, a pesquisa, a organização e o tratamento dos dados e os cartogramas.

A seguir, no capítulo 4, em Aspectos semântico-lexicais, discorremos sobre uso e seleção lexical e sua relação com a semântica. Em 4.1 A norma, explicitamos a noção de Norma, terceiro elemento da tricotomia Sistema, norma e fala, de Coseriu. Em seguida, em 4.2, Análise de traços semânticos, fundamentamos a análise de traços semântico-lexicais, baseando-nos na teoria de Pottier e Rastier.

Em seguida, no capítulo 5, Análise dos dados - área Corpo Humano, desenvolvemos a análise qualitativa dos dados, procurando nos sememas das lexias recolhidas, com base nas definições de dicionários gerais de língua portuguesa e de especialidade, os semas inerentes e aferentes de cada realização pontual do falante.

Segue-se o capítulo 6, Cartogramas, em que se apresentam os resultados da pesquisa em Iguape, nos pontos selecionados, distribuídas pelas variáveis sexo/gênero e faixa etária.

A Conclusão apresenta uma síntese dos resultados a que chegamos com a pesquisa e aponta novos caminhos.

Nos Anexos, acrescentamos as questões da área Corpo Humano do Questionário Semântico-lexical do Projeto ALiB, em sua íntegra, o modelo da Ficha do Sujeito, a Pesquisa Complementar em dicionário de provérbios, de Lacerda (2004) e Dados do IBGE (2007) sobre o município de Iguape. 


\section{A DIALETOLOGIA E A GEOLINGÜÍSTICA}

A linguagem não é apenas expressão do indivíduo, mas também do ambiente social; no primeiro caso é criação, no segundo, é repetição, aceitação de uma norma, ao mesmo tempo histórica e sincrônica. A garantia de compreensão dos atos lingüísticos de comunicação, da produção/recepção de textos envolve variedade, expressão individual, e unidade - todos igualmente importantes. Quando falamos em unidade linguiística, paradoxalmente pressupomos a variedade.

Jakobson (apud CUNHA, 1968, p. 72) comenta:

Sem nenhuma dúvida, para qualquer comunidade lingüística, para todo indivíduo falante existe uma unidade de língua, mas esse código global representa um sistema de subcódigos em comunicação recíproca; cada língua abarca vários sistemas simultâneos, cada um dos quais se caracteriza por uma função diferente.

Uma língua histórica nunca é um único sistema, mas um tecido de diferentes sistemas. Há diferenças do ponto de vista fonético, gramatical e léxico. Para Coseriu (1992), os sistemas dentro de uma língua histórica, em parte divergentes, mas historicamente relacionados, diferenciam-se fundamentalmente em três aspectos: a) socioculturalmente, isto é, constituem distintos níveis de língua e camadas ou estratos socioculturais; b) no aspecto expressivo, isto é, com respeito a diferentes situações do falar e a estilos de língua referentes a elas; c) no espaço, isto é, constituem distintos dialetos. Ao primeiro tipo, denomina variação diastrática; ao segundo, diafásica; e, ao terceiro, diatópica.

A variação diatópica é a mais facilmente percebida pelo falante comum, uma vez que tem consciência de certas particularidades lingüísticas de seu grupo, que se distingue de outro grupo que ocupa diverso espaço geográfico, quanto ao uso da língua, em termos de sotaque, traços fonéticos e vocábulos. É dela que se ocupa a Dialetologia.

A Dialetologia enquadra-se num campo de estudos mais vasto, que é a Etnografia. Por sua vez, a Etnografia estuda a cultura de um povo, quer dizer, o conjunto de idéias, conhecimentos, técnicas e artefatos, padrões de comportamento e de atitudes que caracterizam 
um grupo humano. Exprime, em suma, a herança social, visto que a sua transmissão se dá de geração para geração (SILVA NETO, 1957, p. 15-16).

A noção de dialeto vem dos gregos. Dialektos designava diferentes sistemas, cada um para um determinado gênero literário, e considerados como a língua de uma região. $\mathrm{Na}$ Grécia, o termo dialeto era utilizado para designar tipos específicos de literatura. Assim, os dialetos jônico, dórico, eólico e o ático correspondiam, respectivamente, à poesia épica, às odes, à poesia lírica e ao drama. (DUBOIS, 1978, p.183)

Do ponto de vista puramente lingüístico, os dialetos são falares regionais que apresentam entre si coincidência de traços lingüísticos fundamentais. Eles se caracterizam por ser um sistema de signos e de regras combinatórias da mesma origem que a língua, mas que se desenvolveram de outra forma e não adquiriram o seu status cultural e social.

Segundo um de nossos maiores lingüistas, estudioso do assunto,

Uma diferenciação dialetal explica-se, sempre, em parte, pela história cultural e política e pelos movimentos de população, e, de outra parte, pelas próprias forças centrífugas da linguagem humana, que tendem a cristalizar as variações e criar dialetação em qualquer território relativamente amplo e na medida direta do maior ou menor isolamento das áreas regionais em referência ao centro lingüístico irradiador. (CÂMARA JR., 1976, p. 11)

A Dialetologia é também o estudo conjunto da Geografia Lingüística e dos fenômenos de diferenciação dialetal ou dialetação, pelos quais uma língua, relativamente homogênea numa dada época, sofre, no curso da história, certas variações - diacrônica em certos pontos e de outra natureza noutros - até terminar em dialetos, e mesmo em línguas diferentes (DUBOIS, 1978, p.185).

Segundo Alvar (apud BRANDÃO, 1991, p. 12), por língua entende-se um "sistema lingüístico de que se utiliza uma comunidade falante e que se caracteriza por ser grandemente diferenciado, por possuir alto grau de nivelação, por ser veículo de importante tradição literária e, às vezes, por ter-se imposto a sistemas lingüísticos de sua própria origem". 
Já o dialeto, segundo o mesmo autor, pressupõe "um sistema divergente de uma língua comum, viva ou desaparecida, normalmente com uma concreta limitação geográfica, mas sem forte diferenciação frente a outros de origem comum” (apud BRANDÃO, 1991, p.13).

No caso deste estudo, vamos lidar com "falares regionais", que, na visão ainda de Alvar (id., ibid.), caracterizam-se por serem as peculiaridades expressivas próprias de uma região determinada, que carecem da coerência interna que possui o dialeto. São peculiaridades regionais da língua comum.

No fim do séc. XIX, têm início os estudos das línguas e dialetos falados em tempo real, únicos que se prestavam à observação direta. Mas a maioria dos investigadores não tinha a base sólida ou científica necessária em que pudessem assentar seus estudos.

Foi o suíço Jules Gilliéron, professor de Dialetologia em Paris e autor do Atlas Linguistique de la France (ALF), 1902-1910, quem criou o método da Geografia Lingüística.

Sobre os fundamentos e alcances práticos e teóricos desse método, escreveu Coseriu (1982, p.79):

\footnotetext{
Na terminologia técnica da Lingüística atual, a expressão "geografia lingüística" designa exclusivamente um método dialetológico e comparativo que (...), e que pressupõe o registro em mapas especiais de um número relativamente elevado de formas lingǘsticas (fônicas, lexicais ou gramaticais) comprovadas mediante pesquisa direta e unitária numa rede de pontos de um determinado território, ou que, pelo menos, tem em conta a distribuição das formas no espaço geográfico correspondente à língua, às línguas, aos dialetos ou aos falares estudados.
}

As relações entre o ambiente geográfico e a distribuição espacial dos fatos lingüísticos são tratadas como relações condicionadas política, social e culturalmente e, embora ligados à geografia física, dizem mais respeito à geografia humana e política.

Segundo Iordan (1967, p. 251), “podemos definir la geografia lingüística como el estudio cartográfico de las hablas populares”.

A Geografia Lingüística ocupa-se da freqüência e difusão espacial de fenômenos lingüísticos particulares (variação e mudança fonética, lexical, morfossintática) dentro de uma língua, e dos limites entre as áreas ocupadas por essas variantes, estabelecendo as isoglossas. 
Os atlas lingüísticos são coleções cartográficas de material lingüístico. Estes instrumentos, bem como as técnicas utilizadas, são essencialmente geográficos, mas seus fundamentos e seus fins são lingüísticos. Por esse motivo seu estudo é denominado de Geografia Lingüística ou Geolingüística. Esta última denominação, que passa a ser usada no Brasil a partir do Esboço de um Atlas Lingüístico de Minas Gerais - EALMG (1977), será adotada neste trabalho.

Como diz Aguilera (2005, p. 222),

Os lingüistas, em particular os dialetólogos, sempre reconheceram os vários papéis de um atlas lingüístico, seja como retrato vivo, sincrônico, dos falares de determinado espaço geográfico, seja como fonte de estudo para a reconstrução da história social que se desenvolveu em determinado território ou, ainda, como repositório das múltiplas vozes do presente e do passado que se entrelaçam ou se excluem mutuamente.

Depois da publicação do ALF, a obra de Gilliéron foi reconhecida, não sem algumas ressalvas, e o método geolingüístico passou a ocupar um lugar de destaque na lingüística européia. Prova disso é o grande número de atlas lingüísticos já publicados ou em andamento.

No Brasil, inicialmente, os estudos dialetológicos tiveram idealizadores em Amadeu Amaral, que publicou seu $O$ dialeto caipira em 1920; Antenor Nascentes, autor de $O$ linguajar carioca (1922); Mário Marroquim, autor de A língua do nordeste (1934); Gladstone Chaves de Melo, com A língua do Brasil (1934); Pereira da Costa, com O vocabulário pernambucano (1934), entre outros. Desde a primeira obra citada, destaca-se o interesse pelo estudo da variante brasileira da língua portuguesa, em sua modalidade falada.

Além desses, não podemos deixar de citar Serafim da Silva Neto, autor do Guia para estudos dialectológicos (1957); Nelson Rossi, autor do nosso primeiro atlas de caráter regional, o Atlas Prévio dos Falares Baianos - APFB (1963); e Celso Cunha, um dos nomes mais importantes da filologia em língua portuguesa. Todos eles contribuíram para que se formasse uma "mentalidade dialetológica" e se empreendesse o projeto de um atlas lingüístico brasileiro. 
No entanto, a idéia de um atlas nacional teve de ser adiada, em razão das dificuldades inerentes a um país de dimensões continentais. Como alternativa, foi incentivada a elaboração de atlas regionais. Depois do Atlas Prévio dos Falares Baianos, seguiram-se o Esboço de um Atlas Lingüístico de Minas Gerais (1977), o Atlas Lingüístico da Paraíba (1984), o Atlas Lingüístico de Sergipe (1987), o Atlas Lingüístico do Paraná (1994), o Atlas Lingüísticoetnográfico da Região Sul do Brasil - Vol. I e II (2002), o Atlas Lingüístico de Sergipe II (2002), o Atlas Lingüístico do Amazonas (2004), o Atlas Lingüístico Sonoro do Pará (2004) e o Atlas Lingüístico de Mato Grosso do Sul (2007), além de outros que estão em andamento.

O projeto de um atlas lingüístico do Brasil foi retomado em 1996, por ocasião do Seminário Caminhos e perspectivas para a Geolingüística no Brasil, realizado em Salvador, na Universidade Federal da Bahia. A partir de então, o Comitê Nacional do Projeto ALiB, formado por professores de diversas universidades, tem implementado ações para atingir o objetivo proposto. O primeiro deles, como se lê na apresentação dos Questionários (2001), é “descrever a realidade lingüística do Brasil, no que tange à língua portuguesa, com enfoque na identificação das diferenças diatópicas (fônicas, morfossintáticas, léxico-semânticas e prosódicas) consideradas na perspectiva da Geolingüística."

Em São Paulo, a Prof ${ }^{a}$ Dr $^{\mathrm{a}}$ Irenilde Pereira dos Santos, do Departamento de Lingüística da Faculdade de Filosofia, Letras e Ciências Humanas da Universidade de São Paulo, na disciplina que ministra, Tópicos de Dialetologia e Geolingüística I, tem incentivado a identificação das diferenças diatópicas. Além disso, tem colaborado efetivamente para os estudos geolingüísticos, orientando alunos de pós-graduação em monografias, dissertações e teses. Podemos citar os trabalhos mais recentes, elaborados sob essa perspectiva, na Universidade de São Paulo, sob a orientação da $\operatorname{Prof}^{a} \operatorname{Dr}^{\mathrm{a}}$ Irenilde Pereira dos Santos:

- BUENO, T. R. Exame do gênero feminino em documentos geolingüísticos brasileiros no período de 1957 a 1994. São Paulo. 2002. 83 p. Dissertação (Mestrado em Lingüística). 
- ZAMBO, F. V. Proposta de análise semântico-lexical da lexia nevoeiro e suas variantes lexicais em seis atlas lingüísticos brasileiros. São Paulo. 2002. 126 p. + anexos. Dissertação (Mestrado em Lingüística).

- SILVA, M. do P. S. C. da. Estudo semântico-lexical com vistas ao atlas lingüístico da mesorregião do Marajó/Pará. São Paulo. 2002. 2 v. + anexos. Tese (Doutorado em Lingüística).

- SANTOS, S. S. B. Estudos geolingüísticos de Análise de traços semânticos do campo semântico 'alimentação e cozinha'(questionário do ALiB) no município de Sorocaba. São Paulo. 2002. 227 p. + anexos. Dissertação (Mestrado em Linguística).

- IMAGUIRE, L. M. C. Estudo geolingüístico de alguns municípios do litoral sul paulista: abordagem de Análise de traços semânticos. São Paulo. 2004.431 p. + anexos. Tese (Doutorado em Lingüística).

- ENCARNAÇÃO, M. R. T. da. Estudo geolingüístico de Análise de traços semânticos nas comunidades tradicionais do município de Ilhabela. São Paulo. 2005. 167 p. + anexos. Dissertação (Mestrado em Lingüística).

- CRISTIANINI, A. C. Atlas semântico-lexical da região do Grande ABC. São Paulo. 2007. 3 v. + anexos. Tese (Doutorado em Lingüística).

Também o Grupo de Pesquisa em Dialetologia e Geolingüística da USP - GPDG/USP - coordenado pela Prof ${ }^{a} \operatorname{Dr}^{\mathrm{a}}$ Irenilde Pereira dos Santos - e do qual participam Adriana Cristina Cristianini (vice-coordenadora), Clézio Roberto Gonçalves, Márcia Regina Teixeira da Encarnação, Maria Teresa Nastri de Carvalho e Roseli da Silveira vem desenvolvendo uma intensa atividade de pesquisa sobre temas de geolingüística, sobretudo atlas lingüísticos de municípios do estado de São Paulo. 


\section{O MUNICÍPIO DE IGUAPE}

\subsection{Preliminares}

Antes de apresentar os dados relativos a Iguape, precisamos explicar por que escolhemos o município para tema de nosso estudo sociogeolingüístico.

Nosso interesse pela Dialetologia manifestou-se na graduação, nas aulas de Filologia Românica ministradas pelo Prof. Dr. Salum. Posteriormente, na pós-graduação, voltamos para essa área e, empenhados em contribuir para a descrição da realidade da língua portuguesa falada no Brasil, optamos por empreender um estudo sociogeolingüístico de Iguape. O município, situado no extremo sul do litoral do estado de São Paulo, foi escolhido exatamente por 'fechar' os estudos sobre o litoral paulista, uma vez que já havia teses e dissertações publicadas sobre o litoral norte e sul do estado, como acabamos de fazer referência.

Segundo Araújo (apud DIEGUES, 2005b, p.35), pesquisador do espaço caiçara, a área cultural litorânea da "ubá" (canoa) vai desde Angra dos Reis, no Rio de Janeiro, até Paranaguá, no sul do Paraná. Para a definição da área cultural são levadas em conta as técnicas de subsistência; no caso da caiçara, a agricultura e a pesca. O termo caiçara, de origem tupi-guarani (caa, mato, e içara, armadilha), indica todo um sistema de proteção e de sobrevivência. Era assim que os indígenas chamavam as cercas colocadas em volta da aldeia e outros sistemas de proteção das plantações e de utensílios de pesca. Iguape, município do litoral sul do Estado de São Paulo, faz parte dessa região litorânea, habitada por descendentes da mistura de índios, mulatos, negros e dos diversos tipos de colonizadores que por lá viveram.

Segundo pesquisa de Encarnação (2005), chama-se caiçara, o agricultor-pescador que sobrevive de uma agricultura de subsistência, da pesca artesanal e de algumas relações comerciais para a venda de seu pescado. (...) Essa estreita ligação com o meio natural permitiu-lhe a criação de um saber específico, transmitido de geração a geração. 
Nas entrevistas que colhemos, observamos que "eles se declaram caiçaras como uma forma de resistência, como um fortalecimento de territorialidade com relação àquele espaço que lhes pertence. (...) como uma forma de garantir a sua identidade, de produzir e reproduzir a sua cultura" (ENCARNAÇÃO, 2005).

Para a elaboração do presente capítulo, baseamo-nos em informações extraídas do livro organizado por Pereira Júnior (2005) e que, segundo ele, "reflete e sintetiza o importante empenho de pesquisadores, historiadores e pessoas que estudaram e registraram, ao longo do tempo, a nossa história".

Foram selecionados alguns trechos e capítulos desse livro, acrescidos de dados atualizados do IBGE, para dar uma idéia da importância e peculiaridade do município.

Iguape está localizada no litoral sul paulista, na região do Vale do Ribeira. Pertencente à região administrativa de Registro, integra-se à Bacia Hidrográfica do Ribeira e situa-se no corredor do Mercosul, entre duas importantes capitais: São Paulo e Curitiba. Tem acesso fácil, devido à duplicação (quase total) da BR-116, seja por São Paulo (208 km) ou pelo Paraná (Curitiba - $260 \mathrm{~km})$.

Área: $1.981 \mathrm{~km}^{2}$

População (dados IBGE 2007): Total 28.977

- Zona urbana: 22.127 (dados 2002)

- Zona rural: 5.686 (dados 2002)

Eleitores: 21.811 (dados IBGE Eleição municipal 2004)

Principais atividades econômicas: Turismo, pesca, agricultura, comércio

Topografia: Latitude: $24^{\circ} 42^{\circ} \mathrm{sul}$;

Longitude: $47^{\circ} 33^{\circ}$ oeste;

Altitude: 3 metros

Municípios limítrofes: ao norte: Peruíbe, Itariri e Pedro de Toledo; ao sul: Cananéia e Pariquera-Açú; a leste: Ilha Comprida; a oeste: Miracatu, Juquiá e Pedro de Toledo. 
Distâncias: Belo Horizonte: 705 km; Campinas: 244 km; Rio de Janeiro: 585 km; São Paulo: 175 km; Ribeirão Preto: 460 km; Santos: 183 km; Cananéia: 82 km; Registro: 73 km.

Vias de acesso: Rodovia Federal Régis Bittencourt - BR-116; Rodovia Estadual Prefeito Casimiro Teixeira - SP-222 (Rod. Régis Bittencourt - São Paulo/Iguape); Rodovia Estadual Prefeito Ivo Zanella - SP-222 (via Pariquera-Açú/Iguape).

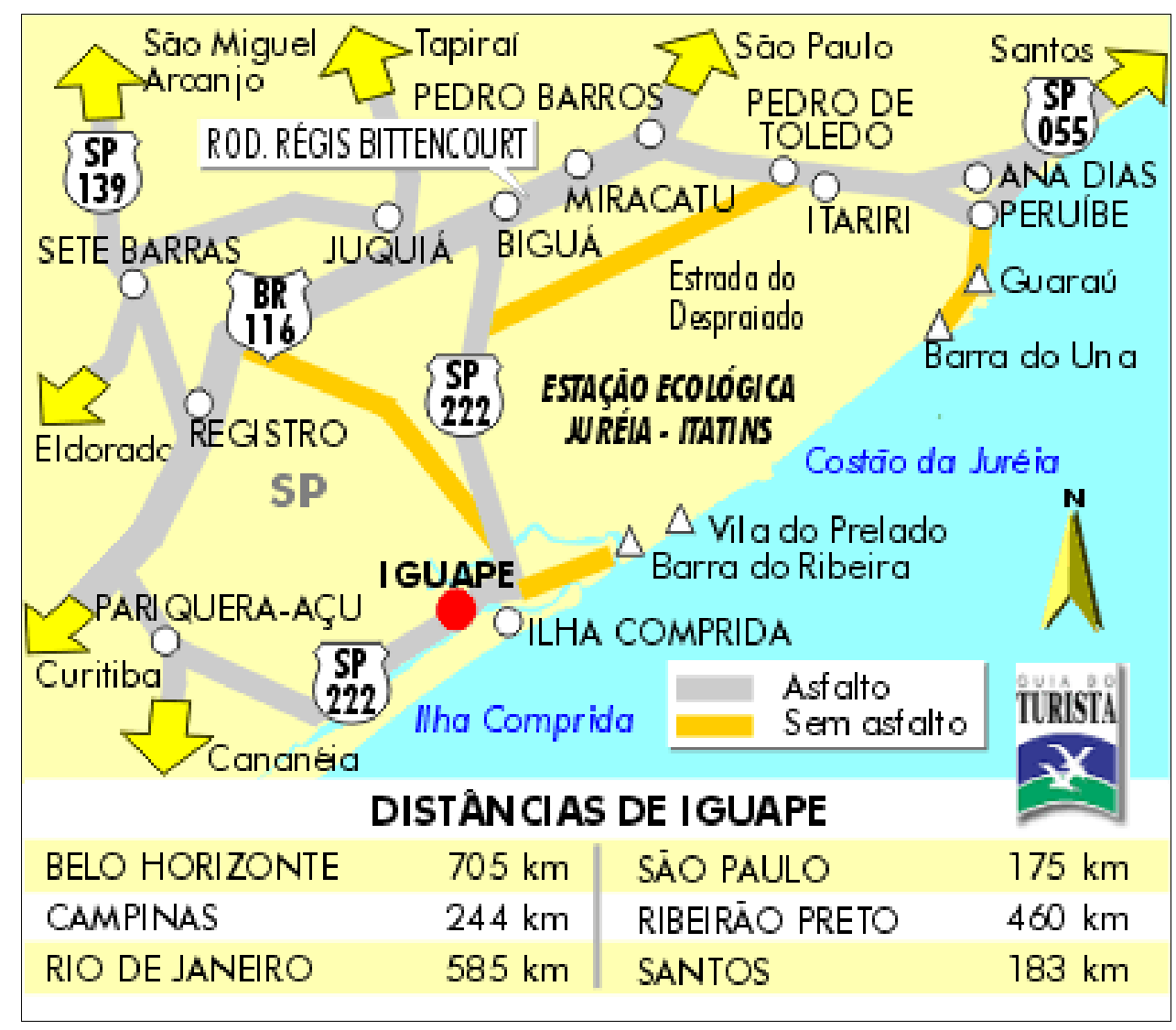

Figura 1 - Distâncias de Iguape [Fonte: http://www.guiadoturista.com.br]

\subsubsection{Clima}

O clima é tropical úmido, amplitude térmica de 22 a $28^{\circ} \mathrm{C}$, com expressivas quedas de temperatura nos meses de inverno, devido à sua localização já próxima à região sul do país. A distribuição das chuvas é irregular, o período mais chuvoso é de outubro a março. A umidade é alta e a nebulosidade é freqüente. O índice pluviométrico é de $1.895 \mathrm{~mm} / \mathrm{ano}$. 


\subsubsection{Relevo}

O relevo é constituído de áreas planas e baixas, formadas pelas margens do rio Ribeira de Iguape e seus afluentes, áreas típicas de formação litorânea, com alguns pontos de morros e ondulações e encostas de serra.

\subsubsection{Vegetação}

A vegetação é variada, de típica vegetação de litoral, áreas de mangue e de restinga, a faixas de encosta da Mata Atlântica.

\subsubsection{Hidrografia}

A Bacia Hidrográfica do Rio Ribeira de Iguape e o Complexo Estuarino Lagunar de Iguape, Cananéia e Paranaguá possuem uma área de 2.830 .666 hectares $\left(28.306 \mathrm{~km}^{2}\right)$, sendo 1.119.133 hectares no Estado do Paraná e 1.711.533 hectares no Estado de São Paulo. Ou seja, é uma imensa área que se divide em treze sub-bacias e abrange trinta e dois municípios, sendo nove no Estado do Paraná e vinte e três no Estado de São Paulo. Os principais rios que atravessam ou fazem fronteira com Iguape são: rio Ribeira de Iguape, rio Peroupava, rio Una do Prelado (rio Comprido), rio das Pedras, rio Una da Aldeia, rio Itimirim e rio Pequeno. O rio Ribeira de Iguape é o principal da região, atravessando o município e desaguando no mar, no bairro Barra do Ribeira, localizado a dezoito quilômetros do centro. Os principais lagos e represas são a Lagoa do Itacolomim (Juréia) e o Estuário Lagunar do Mar Pequeno (Lagamar). Entre as praias, destacam-se Praia do Leste e Praia da Juréia. A hidrografia é denominada pela Bacia do Rio Ribeira de Iguape e seus afluentes e pelos mares internos. 


\section{O Rio Ribeira de Iguape}

É o principal rio da região. Nasce na Serra de Paranapiacaba, Paraná, e deságua no Oceano Atlântico, no Estado de São Paulo, percorrendo uma extensão de quatrocentos e setenta quilômetros, sendo cerca de cento e vinte quilômetros em terras paranaenses.

Formado pelos rios Ribeirão Grande e Açungui, que nascem no Estado do Paraná, a noroeste da Região Metropolitana de Curitiba, a uma altitude de aproximadamente mil metros, o rio desce, inicialmente, rompendo as escarpas das serras, num perfil acidentado até perto de Itapeuna, onde apresenta um desnível de mais de novecentos metros em cerca de duzentos e noventa quilômetros e de noventa metros nos noventa quilômetros seguintes, ficando, na altura da cidade de Registro, ainda a setenta quilômetros da foz, com apenas cinco metros acima do nível do mar.

Sua foz localiza-se no município de Iguape, no local denominado Barra do Ribeira. Desde a conclusão do Valo Grande, no entanto, parte de suas águas não deságua diretamente no mar, mas no Mar Pequeno ou Mar de Dentro, entre o continente e a Ilha Comprida.

\section{Complexo estuarino lagunar de Iguape, Cananéia e Paranaguá}

É um dos mais importantes ecossistemas costeiros, reconhecido por cientistas, ecologistas e organizações internacionais como um dos mais produtivos do planeta, apresentando uma considerável reserva de mangue pouco degradada.

Junto a este complexo ainda se localiza o Parque Estadual da Ilha do Cardoso, visitado periodicamente por diversos segmentos da sociedade, servindo de palco para um aprendizado sobre a natureza como realmente ela é, com a Mata Atlântica quase que intocada e deslumbrantes fauna e flora.

As populações tradicionais caiçaras dependem diretamente dos recursos naturais para sua sobrevivência e qualquer ameaça ao complexo ecossistema ali verificado pode colocar em risco a sustentabilidade socioambiental da região. 


\subsubsection{Fauna e flora}

Iguape abriga cerca de $85 \%$ da área total da Estação Ecológica Juréia-Itatins, considerada um dos maiores tesouros do país. Abriga ainda a Estação Ecológica dos Chauás e diversos ecossistemas associados, como praias, rios, cachoeiras, montanhas e manguezais, ao lado do celeiro marinho do Estuário Lagunar do Mar Pequeno, integrando a região do Lagamar. Portanto, o que podemos encontrar são espécies animais e vegetais típicas de Mata Atlântica, com toda a sua riqueza e diversidade.

\subsubsection{História de Iguape}

Não há consenso quanto ao exato significado da palavra Iguape.Vamos seguir a definição de alguns autores, entre eles o historiador Fortes (2000), para quem a palavra Iguape, em tupi - guarani, tem a seguinte grafia e significado: uwa (=seio dágua água redonda, enseada, baía, bacia fluvial, lagamar) + pe (=em); ou seja, no lagamar, na enseada, na bacia fluvial. O nome é bem apropriado uma vez que o povoado foi estabelecido defronte à Barra de Icapara (local onde deságua o Mar Pequeno).

Iguape é um município da época colonial, fundado nos primeiros anos da colonização pelo Bel. Cosme Fernandes, com o auxílio de índios das redondezas e de alguns desterrados. A data oficial de sua fundação foi fixada em 3 de dezembro de 1538.

O primeiro núcleo de povoação teve início em Icapara (i-caa-para - nome indígena que significa água e mato que correm para a água grande, no caso, o mar). Após constantes ataques de corsários e piratas que freqüentemente assolavam o povoado, e em busca de água potável em abundância, a Vila de Nossa Senhora das Neves de Iguape foi transferida para o local onde hoje se encontra, às margens do Mar Pequeno. A mudança deve ter ocorrido no início do século XVII, por volta de 1614 - já que dados afirmam que este ano marca o início da construção da antiga igreja. Para lá 
foram levadas a Casa da Câmara e Cadeia e a Casa de Fundição do Ouro, considerada a primeira do Brasil.

Não se sabe ao certo a data de elevação de Iguape à categoria de Vila. Tal patente deve ter sido concedida entre os anos de 1600 a 1614, quando o povoado se mudou do Icapara para o local atual, às margens do Mar Pequeno. O município seria criado pela Lei $\mathrm{n}^{\mathrm{o}}$ 17, de 3 de abril de 1849, com o nome de Bom Jesus da Ribeira. Só que o povo iguapense não gostou dessa mudança de nome. Houve protestos da Câmara de Vereadores, do povo em geral, e até do padre. Assim, no ano seguinte, atendendo aos protestos de todos, o Governo Provincial, através da Lei $\mathrm{n}^{\circ} 3$, de 3 de maio de 1850 , mudou o nome da cidade para Bom Jesus de Iguape, que a tradição simplificou, a partir de então, para Iguape.

Nessa época intensifica-se a mineração de ouro na região e a Vila de Nossa Senhora das Neves, como também é conhecida, por ser essa a santa padroeira de Iguape, conhece o seu primeiro ciclo econômico. No final desse mesmo século vem a decadência.

À medida que ia perdendo representatividade nos trabalhos de mineração, em meados do séc. XVIII Iguape começa a se reerguer economicamente, graças a seu porto e a sua localização privilegiada. Com o advento de atividades ligadas à construção naval, estabelecem-se em Iguape muitos estaleiros, nos quais foram construídos inúmeros navios e barcaças, encomendados por importantes armadores de Santos e Rio de Janeiro.

Entre o final do séc. XVIII e o início do séc. XIX, a Vila de Iguape conheceu o seu ciclo econômico mais importante e faustoso: o ciclo do arroz. A elite agrária da Vila concentrou todo o seu capital na lavoura do arroz, cuja qualidade correu o mundo, assegurando a Iguape um lugar privilegiado na exportação desse produto, o que garantia aos abastados "senhores" expressivos dividendos. 
A era do arroz destacou a Vila de Iguape como uma das mais importantes do Império: seu porto, um dos principais do País; sua sociedade, elitizada e fina, comparada à da Corte do Rio de Janeiro.

De 1820 a 1888, a cidade conheceu um período de grande prosperidade e viveu seu apogeu econômico. Chegou a ter 82 engenhos de arroz movidos a água e três a vapor. Beneficiadoras de arroz trabalhavam continuamente, abastecendo uma média de dez navios grandes por semana; bancos garantiam o andamento dos negócios; e seis jornais circulavam na cidade. A elite iguapense estava acostumada a freqüentar espetáculos vindos diretamente da Europa em paquetes luxuosos.

No entanto, em agosto de 1827 foi iniciada a abertura do Canal do Valo Grande. Até essa época, todo o transporte de sacas de arroz era feito em canoas até o Porto do Ribeira, às margens do Rio Ribeira de Iguape, e dali eram transportadas em carroças até o Porto de Iguape (Porto Grande). Para facilitar o transporte das sacas e também reduzir as despesas com fretes, as autoridades da época decidiram abrir esse canal, o que só foi totalmente concluído por volta de 1852 .

Com o tempo, a obra revelou-se fatal para a economia iguapense, pois as margens do Rio Ribeira começaram a desbarrancar devido à força de suas águas, que passaram a entrar pelo canal, e essa areia começou a ser depositada em frente ao Porto de Iguape, o que, aos poucos, foi impedindo a entrada de navios.

A região foi rapidamente entrando em decadência econômica. As pessoas abandonavam Iguape, e quem permanecia encontrava sérias dificuldades para se manter com a pesca de peixes e camarões, muito reduzida nas águas costeiras, invadidas por grande quantidade de água doce.

Depois de muitos anos de lutas, o Valo Grande foi fechado em 3 de dezembro de 1978, pelo então governador Paulo Egydio Martins. A construção de uma barragem nas 
imediações do Porto do Ribeira acarreta problemas sócio-ambientais ligados à pesca e à agricultura até hoje, pois, na verdade, não foram construídas as comportas previstas no projeto original.

Desde a abertura do Valo Grande, a economia de Iguape foi enfraquecendo. Só foi recuperando sua força a partir da segunda metade do séc. XX, quando houve maiores investimentos no setor terciário, ou seja, no setor de comércio e serviços. Mais recentemente, recebeu investimentos na área do turismo e ecoturismo, sendo que estes são considerados, atualmente, a base de sua economia.

\section{Os bairros de Iguape}

Nesse momento vamos conhecer um pouco mais do município de Iguape, alguns de seus bairros, suas características e atividades. Três dentre eles - Icapara, Rocio e Jairê - serão pontos de pesquisa para a constituição do corpus de nosso trabalho.

\section{$\underline{\text { Centro }}$}

Coração do município, no centro concentra-se grande parte dos serviços oferecidos aos munícipes e aos visitantes. O local, como já foi dito, foi escolhido pelos colonizadores que procuravam água potável e proteção do mar aberto. Compreende o maior centro histórico preservado do Estado de São Paulo, com diversos imóveis em alto estilo colonial português, entre eles casarões e igrejas.

O conjunto de construções retrata os ciclos do ouro e do arroz, períodos de grande desenvolvimento econômico de Iguape.

$\underline{\text { Rocio }}$

O Rocio, atualmente o bairro mais populoso do município, está separado do centro pelo canal do Valo Grande; no entanto, já existe uma passarela que permite o fácil acesso de 
pedestres, mas para atingi-lo com veículos motorizados é necessário contornar o Valo até a altura do Porto do Ribeira, um percurso de $3 \mathrm{~km}$.

Lá podemos encontrar uma comunidade diversa, em que o caiçara tradicional se mescla a um grande número de pessoas vindas de outras localidades do País.

\section{$\underline{\text { Subauma }}$}

Situado às margens do Mar Pequeno, quase na divisa com o município de Cananéia, este bairro tem as suas origens ligadas aos primeiros anos da colonização em Iguape. Em 1618, Subauma era conhecido por Sobauma.

É importante lembrar que o Subauma além de ter sido um núcleo de imigração, ainda possuiu um dos portos mais importantes para o desenvolvimento da região.

\section{Porto do Ribeira}

Localizado a $2 \mathrm{~km}$ do centro da cidade, é atualmente a porta de entrada para aqueles que chegam a Iguape por via terrestre. A origem do bairro remonta aos tempos de funcionamento do antigo Porto Fluvial do Ribeira, que deu nome à comunidade, pois era nesse local que aportavam embarcações que desciam o rio Ribeira, especialmente no séc. XIX, quando Iguape tinha uma extensa produção de arroz.

\section{$\underline{\text { Icapara }}$}

Distante dez quilômetros do centro da cidade, o bairro foi a primeira localidade habitada no início da colonização, por volta de 1538 (data oficial da fundação de Iguape). É conhecido por abrigar muitas famílias de pescadores e, por isso, é um dos poucos bairros que ainda mantêm viva a tradição e a cultura caiçara. 


\section{$\underline{\text { Barra do Ribeira }}$}

Distante 18 km do centro de Iguape, é o local onde o rio Ribeira deságua no mar. Com inúmeros atrativos, como o rio Suamirim e a foz do rio Ribeira de Iguape, é excelente para pesca, prática de surfe e passeios de barco e caiaque. É também a porta de entrada para a Estação Ecológica de Juréia-Itatins. O acesso à comunidade inclui travessia por ferry-boat.

Muito apreciado pelos veranistas, é um local que ainda mantém suas características de comunidade caiçara. É na Barra do Ribeira - Juréia que se encontra a antiga imagem de Nossa Senhora de Guadalupe, deixada aqui por espanhóis.

\section{$\underline{\text { Morro Seco }}$}

Bairro distante cerca de sessenta quilômetros do centro da cidade, abriga características culturais muito peculiares. A grande maioria dos moradores locais tem ascendentes das comunidades negras que formavam os quilombos. Por isso a comunidade é considerada um remanescente de Quilombo. Cerca de 30 famílias do bairro desenvolvem a técnica do artesanato em fibra de banana, com o trabalho em máquinas de tear, além de cestarias fabricadas com diversas espécies de cipós. Conservaram a dança fandango e assemelham-se muito a uma comunidade tradicional caiçara.

$\underline{\text { Jairê }}$

Às margens do imponente rio Ribeira, e distante $27 \mathrm{~km}$ do centro da cidade, encontrase o Jairê. O bairro concentra a técnica da confecção da cerâmica utilitária de Iguape, conhecida por panelas pretas, herança cultural deixada por tribos indígenas, provavelmente gês, que habitavam aquela área. As panelas, bem como os potes e outros utensílios, são feitos à base de argila e, durante a queima, tingidas com um extrato retirado da casca do jacatirão, uma árvore nativa de Mata Atlântica e muito abundante na região. 


\section{Iguape, berço da tradição caiçara}

A tradição cultural de Iguape é estampada basicamente nas manifestações folclóricas, representadas pela música, pela dança, pelo artesanato, pelo linguajar e pela culinária. Os maiores exemplos dessas atividades estão na Marujada, na Reiada ou Folia de Reis e no Fandango.

$\mathrm{O}$ artesanato, marca da cultura iguapense, possui fortes influências do negro, do índio e do europeu. Produzem-se as cerâmicas decorativas, utilitárias, mais conhecidas por panelas pretas, além das cestarias, feitas principalmente de cipós e fibras, e o entalhe em madeira, em especial na caixeta.

A fala é uma das características mais marcantes de Iguape. Tão viva e peculiar é a fala do iguapense, que continua até hoje sendo objeto de pesquisa, como é o nosso caso. Além das expressões idiomáticas, o linguajar tem sotaque carregado, melódico e harmonioso, lembrando às vezes o português arcaico, em que é comum, por exemplo, a alternância do som [b] por [v], e vice-versa. 


\section{MÉTODO E PROCEDIMENTOS}

O método que adotamos para a caracterização da fala dos habitantes do município de Iguape seguiu os preceitos da Geolingüística, método da Dialetologia.

O método da Geolingüística consiste em aplicar um questionário a sujeitos de um determinado espaço geográfico, numa rede de pontos, entrevistando um ou mais sujeitos por ponto, os quais representam o falar dos moradores do lugar. Posteriormente esses dados são trabalhados, gerando tabelas, gráficos, quadros e, finalmente, cartogramas.

Como é de praxe nos trabalhos de Geolingüística, primeiramente, procuramos fazer o levantamento sócio-econômico-cultural do local, seguida da pesquisa de campo, transcrição e organização dos dados. Uma vez constituído o corpus, a tabulação dos dados gerou tabelas, quadros e permitiu a sua descrição. Finalmente, fizemos a análise dos aspectos semânticolexicais, com base na pesquisa teórica e na pesquisa dos dicionários gerais de língua portuguesa mais conhecidos, em dicionários de especialidade e dicionários de folclore, entre outros. Por fim, elaboraram-se cartogramas.

Num primeiro momento, a descrição quantitativa do corpus baseou-se nos valores de freqüência e distribuição - absolutos e relativos - dos dados, constantes nas tabelas da variação diatópica e pautou-se pelas lições de estatística lexical de Muller (1968), procedimento que será detalhado neste mesmo capítulo, no item 3.5. Como o uso lingüístico está relacionado à ocupação do espaço físico e ligado à história sócio-econômico-cultural da comunidade, trabalhamos com a noção de norma de Coseriu (1979; 1992), que está fundamentada no capítulo 4.

Para fundamentar a dissertação, antes disso pesquisamos a história social, política, econômica e cultural da localidade escolhida, em sites oficiais, jornais e livros. Na perspectiva da Geolingüística, a seleção e uso de lexias por falantes de uma comunidade pode caracterizar uma visão de mundo peculiar. Ou seja, conhecer a comunidade estudada pode ajudar a explicar os dados. 
Por fim, analisamos aspectos semântico-lexicais das respostas coletadas, com base nas teorias de Pottier (1978) e Rastier (1987).

\subsection{Determinação da rede de pontos e seleção dos sujeitos}

Quando nos propusemos a fazer o estudo sociogeolingüístico de Iguape, não conhecíamos muito bem a região e, a princípio, pensamos em constituir uma rede de pontos que contemplasse todos os bairros do município.

Iguape é o maior município do Estado de São Paulo em extensão, com uma área total de $1981 \mathrm{~km}^{2}$. Possui sete bairros situados na zona urbana e oito na zona rural. Mas sua densidade demográfica $\left(14,5\right.$ habitantes $\left./ \mathrm{km}^{2}\right)$ não justificaria pesquisarmos tantos pontos, os quais, multiplicados pelo número de quatro sujeitos por ponto, resultaria numa amostra, no mínimo, desproporcional e inexeqüível.

Pensamos, então, em adotar o critério estipulado para o Projeto ALiB, de quatro sujeitos por localidade que não as capitais de estado. Mas aí teríamos um único ponto para toda essa imensa área, com quatro sujeitos, “distribuídos eqüitativamente por duas faixas etárias, e contemplando-se os dois sexos" (Projeto ALiB).

Consultamos Coseriu (1982, p. 93) a esse respeito: “(...); mas só uma investigação sistemática numa rede de pontos com 'malhas' suficientemente estreitas, como as exigidas para os atlas lingüísticos, oferece boas garantias no que toca à amplitude do inventário (...).”

Buscando critérios que nos levassem a um número de pontos razoável, fomos pesquisar nos atlas lingüísticos já publicados. Pelo que percebemos, não existe uma orientação única e válida para a determinação de pontos em todas as localidades.

Tirando uma média das duas perspectivas, Projeto ALiB e Coseriu, e procurando constituir um corpus representativo do falar iguapense, resolvemos adotar o critério da relevância histórico-cultural aliado ao da densidade demográfica. 
Determinamos, por fim, que a rede de pontos seria constituída pelos bairros de Icapara, primeira localização do município de Iguape - critério histórico; pelo bairro do Jairê, afastado do centro da cidade e herdeiro de tradições caiçaras e, portanto, indígenas critério cultural; e pelo Rocio, atualmente o bairro mais populoso de Iguape - critério demográfico.

Em cada um dos três pontos selecionados, Icapara, Rocio e Jairê, entrevistamos quatro sujeitos, dois homens e duas mulheres. Foram feitas, no total, doze entrevistas, conforme mostra o quadro-resumo abaixo:

\section{Quadro 1 - Determinação de pontos e número de sujeitos}

\begin{tabular}{|c|c|c|}
\hline $\mathbf{N}^{\mathbf{0}}$ & Ponto & Sujeitos \\
\hline $\mathbf{1}$ & ICAPARA & 4 \\
$\mathbf{2}$ & ROCIO & 4 \\
$\mathbf{3}$ & JAIRÊ & 4 \\
\hline
\end{tabular}

Como convém aos trabalhos de Geolingüística, selecionamos sujeitos naturais da localidade ou que nela tivessem vivido a maior parte de suas vidas, não tendo se afastado do local por período prolongado.

Em todos os pontos, foram entrevistados sujeitos de ambos os sexos/gêneros, porque como observa Silva Neto (1957, p.32):

Tendo-se em conta que o vocabulário feminino é diferente do masculino e que as mulheres, como é natural, conhecem melhor determinadas atividades - as que lhe são tradicionalmente confiadas - é de bom alvitre inquirir, em cada lugar e sempre que possível, um homem e uma mulher. Assim será mais completo o inquérito.

Como a comunidade escolhida para esta pesquisa é um município da época colonial que ficou relativamente isolado dos grandes centros urbanos, não tem indústrias de grande porte, e conserva suas tradições caiçaras, optamos por recolher dados de fala de duas faixas etárias extremas: de jovens de 18 a 30 anos (primeira), e de sujeitos de 66 anos em diante (segunda), mais idosos e que são, via de regra, mais conservadores. 
Ao criarmos mais uma faixa etária (66 anos em diante) em relação às duas contempladas no Projeto ALiB, a saber: 18 a 30 anos e 50 a 65 anos, vamos trabalhar com os dois extremos. Se por um lado isso é bom, pois permite uma visão diacrônica em tempo aparente do dinamismo da fala dos iguapenses, por outro é ruim, pois não permite a comparação com outros estudos que utilizem o método e os procedimentos do Projeto do ALiB.

Nos cartogramas, para registrar cada nova lexia empregada pelos sujeitos, usamos uma cor diferente, identificada na legenda, e para melhor visualizar o falante, resolvemos representá-lo da seguinte maneira, em cada um dos quadrantes:

Quadro 2 - Representação dos sujeitos nos cartogramas

\begin{tabular}{|c|c|c|}
\hline SUJEITOS & SÍMBOLO & QUADRANTE \\
\hline HOMEM - $1^{\text {a }}$ faixa etária & $\sigma^{\lambda}$ & Superior esquerdo \\
\hline MULHER - $1^{\mathrm{a}}$ faixa etária & o & Superior direito \\
\hline HOMEM - $2^{\mathrm{a}}$ faixa etária & 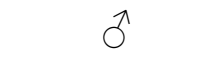 & Inferior esquerdo \\
\hline MULHER - $2^{\mathrm{a}}$ faixa etária & 우 & Inferior direito \\
\hline
\end{tabular}

Os sujeitos foram classificados, para facilitar a identificação dos dados que a eles correspondem, no corpo desta dissertação, pelas siglas do ponto da localidade, do sexo/gênero e da faixa etária. A variável escolaridade, como é comum a todos os sujeitos, não tendo sido considerada, foi dispensada. Assim, ROC-M-1 significa: sujeito do ponto Rocio, do sexo masculino, da $1^{\text {a }}$ faixa etária.

Os dados completos dos doze sujeitos entrevistados, inclusive com o grau de escolaridade que apresentam, podem ser conferidos no quadro a seguir: 
Quadro 3 - Sujeitos entrevistados

\begin{tabular}{|c|c|c|c|}
\hline SUJEITO & INICIAIS & IDADE & ESCOLARIDADE \\
\hline \multicolumn{4}{|c|}{ ICAPARA } \\
\hline ICA-H-1 & D.J. & 22 & Fundamental II \\
\hline ICA-H-2 & G.T. & 83 & $3^{\circ}$ ano \\
\hline ICA-M-1 & R.R.L. & 30 & $7^{a}$ série \\
\hline ICA-M-2 & M.P.S. & 77 & $4^{\circ}$ ano \\
\hline \multicolumn{4}{|c|}{ ROCIO } \\
\hline ROC-H-1 & H.S.M. & 18 & $8^{\mathrm{a}}$ série \\
\hline ROC-H-2 & B.M. & 73 & $1^{\circ}$ ano \\
\hline ROC-M-1 & K.D.R. & 28 & $5^{a}$ série \\
\hline ROC-M-2 & M.O.S. & 69 & analfabeta \\
\hline \multicolumn{4}{|c|}{ JAIRÊ } \\
\hline JAI-H-1 & A.E.M.S. & 22 & $8^{a}$ série \\
\hline JAI-H-2 & M.R. & 66 & $3^{\circ}$ ano \\
\hline JAI-M-1 & C.M.P. & 22 & Fundamental II \\
\hline JAI-M-2 & E.I. & 76 & $2^{\circ}$ ano \\
\hline
\end{tabular}

\subsection{Questionário}

O tipo ideal de investigação geolingüística é a pesquisa in loco. A pesquisa de campo, como é conhecida,

(...) deve ser realizada, sempre que possível, pelo próprio investigador; a experiência tem mostrado que só ele pode aperfeiçoar, no campo, o seu questionário, alargá-lo, sanar-lhe as lacunas ou sentir a conveniência (à vista do material que tem diante dos olhos) de explorar mais a fundo certos fatos lingüísticos (SILVA NETO, 1957, p. 27).

Para a recolha dos dados de fala da pesquisa, nada melhor que usar um questionário previamente elaborado e que abranja um leque de questões sobre vários temas relativos ao homem e a sua vida diária.

Como o objetivo de nossa pesquisa é registrar a variedade lingüística, a realidade da língua portuguesa do Brasil, com enfoque na norma semântico-lexical da localidade, resolvemos trabalhar com o questionário semântico-lexical (QSL) elaborado pelo Comitê Nacional do Projeto ALiB (2001). 
Escolhemos para realizar nosso estudo uma das áreas do QSL do Projeto ALiB. O questionário divide-se em catorze áreas semânticas. A área CORPO HUMANO tem sido uma das mais exploradas nos questionários, no Brasil e em outros países ${ }^{1}$. No QSL do ALiB, ela contempla trinta e duas questões, subdivididas em questões relativas a cabeça, tronco e membros. No presente trabalho, restringimo-nos a estudar as designações relativas a CABEÇA.

Adotamos o QSL porque oferece a dupla vantagem de se poder, com método, investigar determinados grupos de designações e a de ser aplicável a todo o território nacional, permitindo, assim, a possibilidade de comparação dos materiais com outros trabalhos.

O QSL apresenta 202 questões elaboradas numa perspectiva onomasiológica, isto é, partem do conceito para a denominação, como por exemplo, a questão $\mathrm{n}^{\mathrm{o}} 1$ :

\section{Córrego/Riacho}

Como se chama um rio pequeno, de uns dois metros de largura?

Para orientação do pesquisador, as questões vêm precedidas por lexia(s), que servem como tema. Não se espera que os sujeitos "acertem" a questão, mas indiquem a lexia empregada na localidade para aquele conceito.

As questões estão distribuídas em 14 áreas semânticas, a saber: acidentes geográficos, fenômenos atmosféricos, astros e tempo, atividades agropastoris, fauna, corpo humano, ciclos da vida, convívio e comportamento social, religião e crenças, jogos e diversões infantis, habitação, alimentação e cozinha, vestuário e acessórios, vida urbana.

Para a pesquisa da maioria dos fenômenos lingüísticos, o mais habitual dos procedimentos sociolingüísticos é a entrevista. Nela, ocorre a interação de dois indivíduos: o pesquisador e um

\footnotetext{
${ }^{1}$ No questionário do Atlas Linguistique et Ethnographique du Lyonnais (Gardette, 1968), a área semântica 29, Le corps, engloba as questões 1051 a 1088, sobre' les cils, lou peyon', 'la pupille de l'oeil, la poupouna', 'un orgelet', 'les molaires, les masselar', la nuque, le cotivè, le coupè', p. ex. No ALiR, Atlas Linguistique Roman (Alinei, 1993), temos de 356 a 434, questões sobre 'la nuque', le visage', 'les cils', 'la paupière', 'l'oeil', 'les canines', 'les molaires', 'les dents de sagesse', etc.
} 
sujeito entrevistado. Em nossas entrevistas, a despeito de usarmos um questionário, tentamos ser o mais informal possível, já que o objetivo era obter a fala casual, habitual, dos falantes.

Para facilitar o contato, antes da entrevista propriamente dita aplicamos um questionário social para melhor conhecer o sujeito entrevistado e traçar o seu perfil. Esse contato prévio descontraiu o ambiente e ajudou a encaminhar a entrevista.

\subsection{Pesquisa de campo}

Da primeira vez que fomos a Iguape, no início de agosto de 2007, a Festa do Bom Jesus de Iguape, com a tradicional romaria e missa na Basílica, tinha ocorrido no dia anterior à nossa chegada. Mas as barracas que se estendiam por toda a rua da praia, contornavam o campo de futebol, e onde se vendia toda sorte de mercadorias, como roupas, tapetes, sapatos, artigos religiosos, lanches e comidas de todos os tipos, continuavam armadas. Havia muita gente nas ruas, à noite, percorrendo as barracas.

Nesse primeiro contato com a cidade e seus habitantes, soubemos da existência do bairro Icapara, distante aproximadamente dez quilômetros do centro da cidade, onde estávamos. Fomos até lá no dia seguinte e, aproveitando o entusiasmo de um jovem, com quem conversamos no pequeno restaurante de sua família, testamos o questionário. O rapaz de 25 anos, filho de pescador e morador do bairro, concedeu-nos uma ótima entrevista, mas não pudemos aproveitá-la. Ele está fora do perfil desejado, por causa do seu nível de escolaridade: está cursando faculdade em Registro.

Ainda no bairro de Icapara, no mesmo dia, conversamos com uma senhora que nos levou à casa de um morador e ele concordou em responder ao questionário. Mas o gravador não ajudou, logo a pilha acabou e tivemos que interromper e deixar para o dia seguinte. Voltamos no horário marcado para entrevistar os dois, marido e esposa, mas eles tinham saído. Uma das vizinhas, então, nos acolheu e concedeu a entrevista. 
Aproveitamos a ocasião, a estada de três dias, para conhecer melhor a história e a geografia de Iguape. Começamos pelos pontos turísticos ligados à sua história colonial, à sua religiosidade, e ao seu ecossistema privilegiado. Visitamos o Museu de Arte Sacra, o Museu Histórico e Arqueológico, a Basílica do Bom Jesus de Iguape, vários casarões coloniais e outros do início do século XX. Conhecemos o Mar Pequeno, o Valo Grande, a ponte que liga Iguape a Ilha Comprida, entre outras coisas.

Voltamos outras vezes a Iguape e buscamos auxílio com pessoas da cidade para nos indicar os sujeitos para as entrevistas. Na escola estadual do bairro do Rocio, a vicediretora chegou a chamar dois alunos da $1^{a}$ faixa etária, um rapaz e uma moça, para conversarmos. Marcamos a entrevista para o dia seguinte, à tarde, mas nenhum dos dois apareceu.

No bairro do Jairê, com o auxílio da diretora, que nos franqueou a escola e, principalmente, com o auxílio da merendeira, fizemos as quatro entrevistas até a hora do almoço. Gentilmente nos ofereceram almoço na escola, depois do qual voltamos para o centro de Iguape, a quase trinta quilômetros em estrada de terra batida.

As gravações foram feitas com gravador digital MP3 Player Sony, as quais foram transferidas depois para um notebook ou armazenadas em CD-R.

\subsection{Transcrição e organização dos dados}

A transcrição dos dados coletados na pesquisa de campo, ou seja, a transcrição das respostas dadas pelos sujeitos entrevistados seguiu a seguinte organização:

a) as respostas foram registradas sob a forma de lemas, isto é, como aparecem as entradas, os verbetes, nos dicionários: no masculino singular.

No caso da lexia banguela, substantivo e adjetivo comum aos dois gêneros, os sujeitos pesquisados também atualizaram a forma banguelo. 
b) quando o sujeito deu como resposta duas ou três lexias, consideramos para efeito de tabulação apenas a primeira ocorrência.

Ocorreu esta situação com a questão 103, que teve como segunda resposta ora a variante soluço ora jojoca.

c) a variação fonética não foi considerada para efeito de contagem de uma nova lexia, uma vez que se trata de um trabalho relativo ao aspecto semântico-lexical da língua.

Exemplos:

Questão 7:

“... o vento que vai virando em roda e levanta poeira, folhas e outras coisas leves?"

Respostas - redemoinho

rodamoinho

remoinho

Todas as formas acima foram registradas 'redemoinho'.

Questão 84:

“... um bichinho que se gruda nas pernas das pessoas quando elas entram num córrego ou banhado ( $c$ item I)?"

Respostas - sanguessuga

chamechuga

samechuga

chumechuga

Todas as formas acima foram registradas 'sanguessuga'. 


\subsection{Tratamento quantitativo dos dados}

A análise quantitativa do léxico permite descrever certos aspectos da estrutura de léxicos e vocabulários, e pode ser conseguida por diferentes cálculos de freqüência, distribuição, definição de normas, etc., efetivadas pela estatística lexical, por exemplo.

Muller (apud BARBOSA, 1978, p. 88), dentre os vários conjuntos que podem receber o nome de "léxicos", aponta o de um grupo humano que pertence a uma comunidade lingüística. É o conjunto que nos interessa e que pode ser analisado com os métodos e técnicas da estatística lexical, que possibilita a proposição de estimativas cientificamente fundamentadas e a obtenção de dados precisos.

Segundo Barbosa (1978, p. 88),

Léxico e vocabulário são duas concepções complementares, relacionadas a dois níveis de abstração. Com efeito, entende-se por léxico o conjunto das unidades lexicais realizadas e realizáveis, isto é, efetivas e virtuais; e, por vocabulário, o conjunto de unidades lexicais já realizadas, isto é, efetivamente atualizadas em discurso, Por conseguinte, o primeiro contém o segundo (sistema e normas).

Por sua vez, o léxico efetivo, que abrange todas as unidades que já foram atualizadas em discurso, como vocábulos de alta ou baixa frequiência, compreende dois outros subconjuntos: o léxico passivo e o léxico ativo. É o léxico ativo que iremos recolher em nossa pesquisa, o conjunto das lexias de codificação automática, cuja atualização em discurso exige muito pouco esforço do falante.

Adaptando o modelo de Muller (1968) para fins de tratamento quantitativo dos dados coletados em nosso estudo sociogeolingüístico em Iguape, para um universo $\mathrm{N}$ de respostas possíveis, cada resposta à questão proposta será expressa em número cardinal inteiro que corresponde, somadas todas as respostas, ao número de sujeitos entrevistados, ou seja, ao valor absoluto de todas as lexias atualizadas. Considerando-se o número de respostas iguais em relação à mesma questão, face ao total de sujeitos entrevistados, obtemos o valor relativo, 
expresso em número fracionário, até a segunda casa decimal. Se esses números forem coincidentes, temos $100 \%$ de atualização da lexia.

Os cálculos de freqüência podem ser feitos nos moldes descritos acima relativamente às variáveis sexo/gênero, faixa etária e escolaridade. Do mesmo modo, pode-se quantificar a distribuição das ocorrências pelos pontos pesquisados.

\subsection{Cartogramas}

O método da Geolingüística, segundo Coseriu (1982, p. 84), apresenta três etapas principais:

a) recolha de dados, mediante pesquisa in loco com base num questionário padronizado, aplicado a um ou mais sujeitos, em todos os pontos escolhidos;

b) registro do material coletado em mapas, que constituem os atlas lingüísticos;

c) análise (estudo e interpretação) do material proporcionado pelos mapas.

Em vez do termo "mapa" ou "carta”, bastante usado por pesquisadores de Geolingüística, utilizaremos a denominação "cartograma", como adotou Cristianini (2008), em sua tese de Doutorado. Também a Prof ${ }^{\mathrm{a}} \operatorname{Dr}^{\mathrm{a}}$ Ana Maria Marangoni, do Departamento de Geografia da USP, aconselha que assim se proceda. Segundo a especialista em cartografia, os cartogramas visam à precisão, e não à exatidão. Cartogramas, segundo Ferreira, em seu dicionário eletrônico, são mapas ou quadros em que, por meio de pontos, figuras e linhas, previamente convencionados, representase um fenômeno quanto à sua área de ocorrência, importância, movimentação e evolução.

A segunda etapa de nosso trabalho será, portanto, o registro do material recolhido em mapas ou cartogramas. Não elaboraremos um atlas lingüístico, que são coleções cartográficas de material lingüístico, mas registraremos a área pesquisada em dezesseis cartogramas referentes a cada lexia, afora os mapas do Brasil, de São Paulo e o mapa base de Iguape com os pontos da pesquisa assinalados. 
Coseriu (1982, p. 83), de acordo com os fatos lingüísticos que registram, classifica os mapas lingüísticos em:

- Mapas fonéticos - variantes de um fonema comprovadas nos pontos investigados;

- Mapas lexicais - registro das "palavras" empregadas para expressar o mesmo conceito;

- Mapas propriamente lingüísticos - registro em sua integridade fônica e morfológica de expressões concretamente comprovadas em cada ponto investigado.

Quanto à forma de apresentação, estipula que os mapas podem ser:

- sintéticos - estabelecem os limites das áreas correspondentes às formas típicas comprovadas;

- pontuais - registram fielmente as formas comprovadas em todos e em cada um dos pontos investigados.

Em nosso estudo, como lidamos com fatos linguiísticos de caráter lexical, elaboramos mapas lexicais que, segundo a classificação de Coseriu (1982, p. 83), registram todas as variantes lexicais empregadas para expressar o mesmo conceito.

A terceira e última etapa é o estudo semântico-lexical e a interpretação do material proporcionado pelos cartogramas. 


\section{ASPECTOS SEMÂNTICO-LEXICAIS}

\subsection{A Norma}

Em vista das dificuldades encontradas na definição dos conceitos de "língua" e "fala", introduzidos na ciência lingüística por Saussure (1972), e logo aceitos ou reelaborados por uma série de lingüistas, Coseriu (1979) se propôs a apresentar sua visão tripartite, partindo de uma concepção monista da linguagem. Para ele, língua e fala não podem se opor, já que aquela está presente nesta e se manifesta concretamente nos atos lingüísticos.

Após a análise e a crítica de várias concepções, Coseriu (1979) conclui que, de maneira concreta, a linguagem existe só e exclusivamente como falar, como atividade lingüística, e que língua e fala não podem ser consideradas como realidades autônomas, uma vez que a fala é a realização da língua e, por outro lado, a língua é condição da fala.

Ou seja, Coseriu (1979) apresenta sua visão tripartite da linguagem em que o conceito de língua como sistema abstrato de oposições funcionais implica o desenvolvimento do conceito de norma (abstração intermediária), cujas premissas considera já estarem presentes em Saussure. Acredita ainda que, do ponto de vista metodológico, ela possa revelar-se útil, proveitosa e até necessária na lingüística teórica e na lingüística histórica, tanto sincrônica quanto diacrônica.

Para melhor explicar a distinção entre sistema normal e sistema funcional, para Coseriu (1979) norma e sistema, ele evoca a célebre analogia saussuriana com o xadrez, em que entre o "código" do jogo e sua realização, nesta ou naquela partida, podem-se comprovar certos movimentos, certos aspectos constantes, que não modificam as regras, o sistema, mas que caracterizam a maneira de jogar de um indivíduo ou de um grupo de indivíduos, e constituem os traços normais, a norma, da realização do "código" pelos mesmos.

Coseriu (1992, p. 68), retomando suas considerações, afirma que 
Sistema é o que é possível numa língua, com base nas distinções que faz essa língua e com base nos procedimentos que ela tem para expressar as respectivas distinções. Sistema é, portanto, o que é possível com base nas regras de uma língua.

Norma é, pelo contrário, o que se realiza e se tem realizado efetivamente. A norma é uma limitação do sistema, já que não se realizam todas as possibilidades do mesmo.

Assim, pois, o sistema contém o possível, isto é, tanto o realizado como também o ainda não realizado; a norma contém o efetivamente realizado.

A norma e o sistema da língua correspondem, juntos, aproximadamente, à langue saussuriana. O falar concreto corresponde mais ou menos à parole de Saussure (1972) e poderia ser chamado também de "fala" (no sentido de processo, de dinâmica, que contém o vocábulo discurso). (COSERIU, 1992, p. 68)

$\frac{\text { Correção }}{\text { Aceitabilidade }}=\frac{\text { Sistema }}{\text { Norma }}$

A norma e o sistema não constituem variedade interna da língua histórica, mas representam a medida ou o grau de estruturação dessa mesma norma.

A realidade da língua é movimento e, mesmo quando considerada sincronicamente, fundamenta-se num equilíbrio instável.

Se uma língua pode abarcar vários sistemas, ou seja, as formas ideais de sua realização, a sua dinamicidade, o seu modo de fazer-se, pode também admitir várias normas, que representam modelos, escolhas que se consagraram dentro das possibilidades de realizações de um sistema lingüístico. Como pondera Coseriu (apud CUNHA,1986, p. 73) se "é um sistema de realizações obrigadas, consagradas social e culturalmente", a norma não corresponde, como pensam certos gramáticos, ao que se pode ou se deve dizer, mas "ao que já se disse e tradicionalmente se diz na comunidade considerada."

Os atos lingüísticos, enquanto atos de comunicação, são acima de tudo escolha, seleção. Tendo em vista a condição essencial da linguagem, que é a comunicação, esses atos pautam-se pela re-criação nos moldes de uma "língua anterior", sistema estabelecido na própria comunidade 
sobre a base dos atos lingüísticos precedentes ao ato com o qual nos deparamos. Ele oferece os modelos para esse mesmo ato e é ponto de referência em relação a uma inovação.

Em outras palavras, o falante utiliza, para a expressão de suas percepções inéditas, a repetição de modelos normais e já tradicionais na comunidade, e que constituem a norma. Assim sendo, no universo significante em que vivemos, cada comunidade escolhe, a cada época, certas significações e exclui outras.

Na perspectiva da Geolingüística, a seleção e uso de lexemas pelo conjunto de seus semas (sememas), pode caracterizar uma visão de mundo peculiar, relacionada à ocupação do espaço físico e ligada à história sócio-econômico-cultural da comunidade. Nesse sentido os atlas lingüísticos funcionam muito bem como "instantâneos" que captam o uso de uma língua numa determinada época e lugar.

Segundo Greimas e Courtés (1979, p. 253), os lexemas, enquanto configuração que reúne, de modo mais ou menos acidental, diferentes sememas, apresenta-se mais como o produto da história ou do uso que como o da estrutura.

É isso que pretendemos mostrar neste trabalho: que a norma compartilhada por uma comunidade lingüística reflete-se no léxico e varia, de época para época, de acordo com condicionantes que vão ampliar ou reduzir o espectro dos semas dos lexemas selecionados.

\subsection{Análise de traços semânticos}

Tendo em vista os objetivos acima, fazemos um estudo de traços semânticos, baseado em Pottier (1978) e Rastier (1987), das respostas às questões de nº 89 a 105 do Questionário Semântico-Lexical (QSL) do Projeto ALiB, correspondente à área Corpo Humano, aplicado a sujeitos naturais de Iguape, litoral sul do Estado de São Paulo.

Para abordar aspectos semântico-lexicais das respostas dadas, temos que começar pela designação diferenciada das unidades lexicais. Segundo Quemada (apud ALVES, 1999, p. 69- 
70) temos que levar em conta três planos, de acordo com a expansão da dicotomia saussuriana língua e fala, acrescida do conceito de norma. Trata-se dos planos do discurso, do código e do sistema, a que correspondem os lexes, as lexias e os lexemas, respectivamente.

\section{Quadro 4 - Lexes, lexias e lexemas}

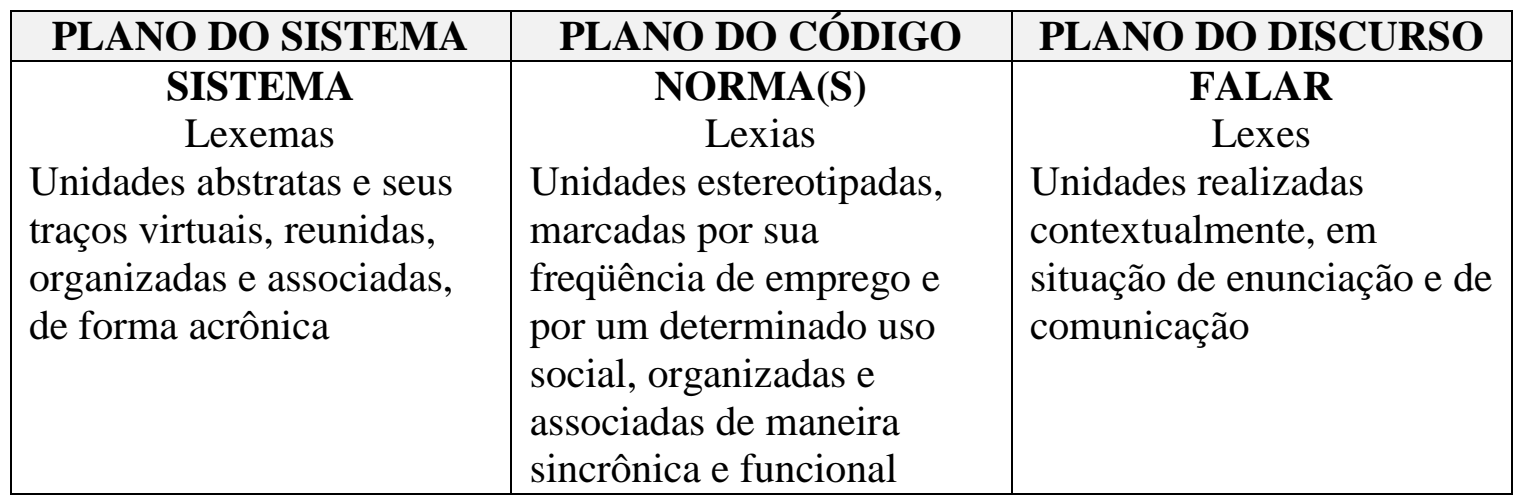

Trabalhamos no plano do código, em que se situam as lexias, as unidades lexicais por excelência. As lexias constituem as unidades de significação estereotipadas (lexicalizadas), que, em um estado de língua delimitado sincronicamente, e em um determinado universo sociocultural, permitem nomear um objeto, uma noção, uma qualidade ou uma ação. As lexias são os elementos do léxico, a soma organizada de todas as unidades da língua, conjunto sincronicamente estruturado por subconjuntos específicos, diassistemicamente marcados.

Pode ser explicada assim a origem do termo lexia:

Pottier (1978) escolheu o termo lexia para designar as unidades do conteúdo que têm
dimensões variáveis, indo de simples lexemas ("cão") aos sintagmas fixos ("pé-de-
moleque"), e para tentar assim substituir o termo palavra, ao qual parece impossível
se dar uma definição suficientemente geral. Ele propõe a distinção de três tipos de
lexias: lexias simples (lexemas e lexemas afixados, como "cavalo",
"anticonstitucional"), lexias compostas ("couve-flor", "guarda-roupa") e lexias
complexas ("pé-de-moleque", "Maria-vai-com-as-outras") (GREIMAS e
COURTÉS, 1979, p.254).

Concordamos com Biderman (1999, p. 89), quando diz que o termo lexia, proposto por Pottier (1978), é muito útil, por ser um termo técnico. Assim, no plano da língua, o termo lexema refere a unidade abstrata do léxico. As manifestações discursivas dos lexemas devem ser referidas tecnicamente como lexias. 
Para Pottier (apud VILELA,1979, p.22), é essencial a noção de semema, um dos possíveis "efeitos de sentido" contidos virtualmente no lexema (e na lexia) e realizados no discurso (na lexe). Ou seja, realizam-se no plano da "parole", mas são valores virtuais da "langue". O ponto de partida de nossa análise é o semema, entendido como conjunto de traços semânticos pertinentes ou os semas que entram na definição de substância do lexema.

Fundamentamos nossa concepção de lexema/semema em Pottier (1978), que Rastier (1987) desenvolveu posteriormente, distinguindo dois tipos de semas: (i) os inerentes, que são provenientes do sistema funcional da língua e são os traços específicos, denotativos. São classificados, ainda, como distintivos, definitórios e universais; e ii) os semas aferentes, que remetem a normas socializadas. Eles não são distintivos, não são definitórios e não são universais. Caracterizam-se como conotativos e podem ser produzidos por uma inferência, que traduz uma expectativa socializada.

Resumindo, segundo explica Greimas (1979, p. 253), o lexema empreende um percurso que vai desde o momento de sua semiose, quando da junção do formante com o núcleo sêmico que ele recobre, passa pela sua realização sintagmática e conseqüente inserção no enunciado, de onde ele recolhe os semas contextuais que lhe possibilitam constituir-se em semema, enquanto prepara o caminho para a manifestação da significação. Nesse processo, do mais abstrato para o mais concreto, do lexema para a lexia e em seguida para o lexe, pode ocorrer a atualização de semas subjacentes que venham agregar-se aos já existentes, ampliando, reduzindo ou provocando desvios eufóricos/disfóricos no inventário dos semas.

Esse percurso, nem sempre linear do lexema até sua manifestação no discurso, traduzse, na pesquisa da fala de comunidades lingüísticas, em variantes lexicais, isto é, em lexias muitas vezes inusitadas.

Atualmente, a simples elaboração de um rol de variantes lingüísticas, coletadas e lançadas num cartograma, não responde mais às necessidades de mapeamento da diversidade 
lingüística brasileira. Nem condiz com o modelo da nova Geolingüística, de caráter pluridimensional.

Nosso estudo busca englobar, além do registro da freqüência e distribuição da variedade lingüística própria da região, dimensionadas pelas variáveis sexo/gênero e faixa etária, a análise de aspectos semântico-lexicais das lexias recolhidas.

Jakobson (apud RASTIER, p. 17-18) foi o primeiro a tentar uma análise semântica estrutural das unidades lexicais, a partir das unidades mínimas fonológicas. Segundo Pottier (1972, p.42), o lexema (ou morfema lexical) pertence a um inventário aberto e muito extenso. No plano da língua, em disponibilidade permanente, esse lexema liga-se a um grande número de esferas semânticas possíveis. No ato da comunicação, no plano do discurso, somente algumas áreas são atualizadas, e então o lexema acontece num domínio específico.

Assim, 'são' pode pertencer ao domínio "religião ou "saúde". O dicionário procura abarcar todos esses domínios, mas só a situação de discurso atualiza um dos domínios, uma vez que a significação é relacional. E, muitas vezes, a ligação entre eles permanece subjacente.

A significação do lexema (morfema lexical), assim concebido, é seu semema. O semema, segundo Pottier (1972, p.43), é composto de três grupos de semas:

- os específicos - que permitem distinguir os morfemas mais próximos de um mesmo domínio. Eles são descritivos ou combinatórios;

- os genéricos - que indicam que o lexema pertence a um campo conceitual como /material/, /humano/, /contínuo/ etc. Podem ser descritivos ou combinatórios;

- virtuais - que correspondem às associações disponíveis na consciência dos locutores de uma comunidade homogênea (vermelho - /perigo/), e que podem ser atualizados facultativamente no discurso.

Segundo Lyons (1963, p. 267-268), a semântica lexical estrutural, apesar das críticas que lhe têm sido feitas (como a falta de formalização, etc), ainda não encontrou qualquer substituto nas correntes lingüísticas, mesmo nas chamadas semânticas provenientes da gramática transformacional. 
Trabalhamos com lexias da classe de designação que, segundo Barbosa (1978, p. 81), representam linguisticamente o mundo dos objetos biofísicos e socioculturais, e são, ao mesmo tempo, geradoras e reflexo da "realidade" sócio-lingüístico-cultural de uma comunidade.

Entendemos, no entanto, que entre o nome e a coisa designada, desenvolve-se toda uma rede ou sistema de relações, já desenvolvidas conceitualmente por Pottier (1978) e Rastier (1987) e aqui examinadas em capítulo anterior. Ora deparamos com lexias utilizadas na língua comum, ora com termos da linguagem de especialidade, usados por profissionais da área médica e odontológica.

A língua comum ou geral representa um subconjunto da língua entendida em sentido global. Ela se compõe de um conjunto de regras, unidades e restrições do conhecimento da maioria de seus usuários. As unidades da língua comum são utilizadas em situações que podem ser classificadas como "não marcadas”, como esclarece Cabré (1993, p.128).

Por linguagem de especialidade, designa-se um conjunto de subcódigos - parcialmente coincidentes com o subcódigo da língua comum - que se caracterizam por particularidades, próprias e específicas de cada um deles. As linguagens de especialidade são utilizadas em situações ditas “marcadas” (CABRÉ, 1993, id.).

O conjunto das unidades da linguagem de especialidade de uma determinada disciplina e também de um âmbito de atividade específica constituem a terminologia própria dessa especialidade. Os termos, que são a unidade de base da terminologia, designam os conceitos próprios de cada disciplina especializada (CABRÉ, 1993, id.).

Já dissemos em outra oportunidade que a linguagem é produto da cultura. E a cultura de um povo, afirma Cascudo (2004, p.39), pode formar e transformar: modificar uma cerimônia, uma técnica de produção agrícola, abandonar certos vocábulos por outros ou fazêlos ter significação diferente, entre outras coisas. 
Já dissemos, também, que não se pode dissociar o léxico de uma comunidade do contexto sócio-econômico-cultural que ele ao mesmo tempo gera e reflete. Nem dos grupos e indivíduos que dele se utilizam. As línguas delimitam aspectos de experiências únicas vividas por cada povo. Em face às demais formas de cultura, Câmara Jr (apud LOPES, p. 21) salienta que "uma língua é o seu resultado ou súmula; o meio para ela operar; a condição para ela existir".

A linguagem é patrimônio cultural de um povo. Blöndel (apud Câmara Jr.,1976, p.32) afirma que "a língua, como meio coletivo de representação e comunicação, traduz um ‘pensamento socializado"”. Cascudo (2004, p.239) discorre sobre a importância que o homem atribui ao corpo humano, refletida nos nomes dados em relação a ele na cultura de vários povos e civilizações.

O corpo humano foi para o próprio homem seu mundo inicial e continua sendo, instrumento miraculoso de adaptação e conquista, princípio e fim de todas as cousas circunjacentes, para ele viventes e úteis.

Tudo fora feito para o serviço humano e seu domínio, terras, águas, plantas e feras. Sol e lua eram suas lâmpadas e as estrelas deviam guiá-lo nas noites escuras. $\mathrm{O}$ mundo se organizou para o primeiro homem. Ele deu nome e função a tudo quanto existe. As civilizações, pelas suas culturas, são capitalizações desta herança milenar, acrescida na experiência dos tempos. O corpo humano foi, naturalmente, a medida de todas as dimensões. Cidades, estradas, aquedutos e pontes são projeções estáticas das proporções humanas. São necessidades, serviços indispensáveis e permanentes que ele planejou e construiu, com mão e pé. O módulo foi seu corpo. O edifício conserva o pé e a mão, e seus múltiplos e submúltiplos, como padrões incomparáveis.

O domínio da Semântica é de fundamental importância para a compreensão das relações entre língua e cultura.

Na primeira metade do século XX, abandonando a dimensão diacrônica das pesquisas em benefício de uma descrição sincrônica dos fatos de significação, a Semântica reserva para si a tarefa de reconhecimento e análise dos campos semânticos (ou nocionais, ou conceptuais). Rohlfs (1979, p. 46-47), como exemplo da rede de relações que se forma entre o nome e a coisa designada, relata que em certas regiões o homem, artesãos e aldeães, identifica toda e qualquer atividade com o ato sexual, e lhe dá sua correspondente expressão lingüística. $\mathrm{O}$ 
mesmo acontece entre as tribos primitivas do Pacífico: a exteriorização lingüística das idéias se reveste de imagens sexuais condicionadas; assim também nas línguas européias a fantasia sexual na formação de nomes de instrumentos tem um papel considerável.

A exteriorização lingüística de certas idéias, acreditam alguns, desencadeia forças sobrenaturais, maléficas ou benéficas. Daí algumas manifestações serem interditadas, evitando-se, assim, os efeitos maléficos desse poder. São os tabus lingüísticos.

Segundo Willems (apud GUÉRIOS, 1979, p. 1), tabu é “proibição ligada a certas representações mágicas ou religiosas. Existe uma infinidade de tabus cuja infração envolve automaticamente a aplicação de sanções naturais”.

O recurso que se usa para exteriorizar a idéia expressa por um tabu são os meios indiretos ou meios diretos dissimulados, isto é, expressões substitutas que encobrem o ser sagrado-proibido.

Conforme explica Guérios (1979, p. 12), vários são os processos de substituição do termo tabuizado: por gesticulação, por sinônimo, por expressão genérica, por antífrase, por disfemismo, por diminutivo, por deformação fonética, por mudança sintática, por plural, por gênero neutro, pronunciado em voz baixa, etc. Vamos encontrar alguns desses procedimentos em lexias recolhidas em nosso estudo do falar de Iguape.

Até hoje, pronunciar o nome de certas partes do corpo humano é alvo de tabu lingüístico, assim como o são o de doenças e defeitos físicos. Apesar de ser fenômeno universal e de todos os tempos, o tabu varia na intensidade e de povo para povo, isto é, o que é tabu numa comunidade, numa família, pode não ser em outra.

Além dos dados de frequiência e distribuição das lexias/respostas, analisamos o feixe de traços semânticos chamados semas que compõem os sememas. Buscamos relacionar a seleção e uso de certas lexias, pelo conjunto de seus semas (sememas), a uma visão de mundo compartilhada pela comunidade. 


\section{ANÁLISE DOS DADOS: A ÁREA CORPO HUMANO}

Quando eu morrer quero ficar,

Não contem aos meus inimigos,

Sepultado em minha cidade,

Saudade.

Meus pés enterrem na rua Aurora, No Paiçandu deixem meu sexo, Na Lopes Chaves a cabeça Esqueçam.

No Pátio do Colégio afundem O meu coração paulistano: Um coração vivo e um defunto Bem juntos.

Escondam no Correio o ouvido Direito, o esquerdo nos Telégrafos, Quero saber da vida alheia, Sereia.

O nariz guardem nos rosais, A língua no alto do Ipiranga Para cantar a liberdade.

Saudade ...

Os olhos lá no Jaraguá

Assistirão ao que há-de vir, Ojoelho na Universidade, Saudade ...

As mãos atirem por aí, Que desvivam como viveram, As tripas atirem pro Diabo, Que o espírito será de Deus. Adeus.

(MÁRIO de ANDRADE, 1987) (Obs.: grifos nossos)

No poema de Mário de Andrade, nossos grifos destacam partes não apenas do corpo humano como também elementos que compõem a área Corpo Humano, como a cabeça, que agora passamos a estudar.

Essa parte do corpo humano, a cabeça, sempre mereceu a atenção do homem por sua funcionalidade, por ser a matriz de todos os pensamentos e comandos do corpo, e ao mesmo tempo por sua fragilidade, por sua necessidade de proteção. 


\title{
Para Cascudo:
}

O caçador primitivo valorizou seus órgãos. Boa parte dos essenciais estava na cabeça, a visão, o olfato, o paladar, a audição. (...) Naquele tempo em que o mundo amanhecia para a espécie humana os órgãos significavam realmente o instrumental da vida diária e batalhada.

(...) Para apanhar o fruto ou abater a caça já estavam escolhidos e selecionados os gestos definitivos e próprios da ação. Mãos e pés cumpriam o desenho íntimo e precioso da arrancada. E tudo estava dentro da cabeça. A cabeça era a caixa da riqueza sensível e vital.

Era também a parte mais alta do corpo. De maior evidência e notoriedade. (...) Por isso a cabeça é o princípio, governo, disciplina. (...) A primeira insígnia de chefia só podia ser colocada na cabeça do aclamado. As formas distintivas da soberania ficam na cabeça dos reis e dos papas. (...) Cabeça é chefia, inteligência, astúcia, previsão, planejamento. É a sede do comando, da decisão, da vontade orientadora.

Exibir o crânio do inimigo vencido é a prova mais evidente de sua derrota inegável. (CASCUDO, 2004, p. 245-247)

Rohlfs (1979, p.200-202), em seu estudo sobre o léxico românico, inclui um capítulo para a diferenciação léxica das línguas românicas, de onde extraímos o seguinte subtítulo:

\section{CAPUT-CAPITIA}

\begin{abstract}
Vigorosas expressões o povo usa para designar a 'cabeça'. Assim como nos romances atuais, junto à palavra oficial se usam vozes mais expressivas. Em fr. pomme, poire, melon, citron, citrouille, boule, tronche; it. zucca, cucuzza, borella; esp. olla, calabaza; rum. diblã 'violino', tidvã 'calabaza', ciuturã 'cubo', etc.). O velho caput se conservou como cap na Romênia, como capo na Itália central e meridional, e em zonas muito limitadas da Itália superior (lomb. cò, friul, ciaf), em fr. merid. cap, em cat. cap e em réticochiauoucheu.

O espanhol e o português desde seus mais antigos textos só conhecem caput no sentido de (cabo, fim, mango, amarra), embora cabeza e cabeça tenham ocupado seu lugar para denominar a parte do corpo. A etimologia destas últimas formas é o latim capitium 'abertura que as túnicas tinham para a cabeça', significação com a qual se conhecia a palavra na França medieval, fr. ant. chavez, prov. cabetz. Outras acepções, como por exemplo, o it. cavezza 'cabresto', prov. ant. cabessa 'dossier d'un lit', gasc. cabessa 'parte do arado', prov. cabetz 'cabeceira o leito', permitem supor que a denominação hispanorromânica da palavra se tenha formado, passando ao homem a expressividade lingüística das designações animais ou do mundo inanimado.
\end{abstract}

A cabeça, uma das partes do corpo humano, é composta de "sete buracos", como diz

Caetano Veloso na canção "A Tua Presença Morena”: dois olhos, dois ouvidos, duas narinas

(nariz), uma boca.

A seguir, passamos à análise das respostas das questões relativas a cabeça, reagrupadas em questões sobre: olhos, boca, nariz e pescoço. 


\subsection{Olhos}

Dos olhos, Cascudo diz

Na cerâmica grega, desde o século VI a.C., em vasos da Ática, Corinto, Mileto, Rodes, pela Ásia Menor, pela Etrúria, aparece comumente a cabeça da Medusa que, petrificando quem a olhasse, tornou-se amuleto para deter a má sorte, as forças malfazejas, tudo quanto um olhar pode irradiar no sentido da potência adversa. A cabeça da Medusa que o herói Perseu decepara denominava-se "gorgoneion", e é encontrada nos vasos, na ombreira das portas, nos escudos, no punho dos gládios, nas túnicas, na proa dos barcos, na louça de uso diário, especialmente no vasilhame de beber, nas jóias, nos móveis, cadeiras, bisélios, leitos, nas colunas de mármore, na roda dos carros sagrados, nas liteiras, nos anfiteatros, aquedutos, marcos miliários. Nem sempre se depara o "gorgoneion" mas simplesmente os dois olhos ou em número bem maior. Há peças decoradas inteiramente pelos olhos.

A finalidade é a mesma: defender, afastar, evitar a influência maléfica do mauolhado, fascínio, olho-grande, olhão, mauvais oeil, malocchio, Evil eye, Böse blick, Jettatura, mal de ojo, daño de aojamiento.

Por isso, gregos e romanos gravavam, pintavam, esculpiam olhos nos túmulos para que os mortos repousassem em paz e livres do que o mau-olhar pode fazer. (...) Os deuses precisavam defender-se do olho-mau, tão poderoso quanto eles (CASCUDO, 2004, p.249-250).

\subsubsection{Pálpebras}

QUESTÃO 89 -... esta parte que cobre o olho? Apontar.

\section{Freqüência e distribuição}

A tabela a seguir reúne as respostas referentes à questão sobre pálpebra, colhidas em Iguape:

Tabela 1 - Freqüência geral da questão 89 - Iguape

\begin{tabular}{lrr}
\hline \multirow{2}{*}{ Lexia } & \multicolumn{2}{c}{ Freqüência } \\
\cline { 2 - 3 } & VA & \multicolumn{1}{c}{ VR (\%) } \\
\hline Pálpebra & 4 & 33,33 \\
Pipela & 2 & 16,67 \\
Pestana & 1 & 8,33 \\
Abstenções & 5 & 41,67 \\
$\quad$ Total & $\mathbf{1 2}$ & $\mathbf{1 0 0 , 0 0}$ \\
\hline
\end{tabular}


Um terço dos sujeitos ouvidos em Iguape emprega o termo técnico-científico pálpebra para se referir a essa parte do corpo humano.

Pequena parcela emprega a lexia pipela, que nos parece ser o pólo contrário da especialidade, próximo da banalização, segundo o sentido atribuído por Cabré (1993, p.136), quando afirma “(...) a menudo trasladamos los temas especializados, en el sentido más ortodoxo del término, a la vida cotidiana. Este fenómeno ha sido denominado, por autores como Galisson, banalización.”

Não encontramos lexicalizada, em dicionários de língua geral ou de especialidade, a variante registrada em Iguape. Mesmo em atlas regionais não se registra essa forma, apenas em Diegues (2005, p. 210) encontramos pipela na acepção única 'pálpebra'.

Assim como nos dois atlas regionais pesquisados, o ALPR (1984) e o ALMS (2007), a lexia pestana foi selecionada por um dos sujeitos como resposta à questão sobre pálpebra.

A maior parte dos sujeitos entrevistados, quase 50\% dos falantes/ouvintes, não conhece ou não conseguiu selecionar uma lexia que designasse o referente pálpebra.

Entre sujeitos do gênero feminino, é alta a frequiência, em valores absolutos e relativos, de uso do termo pálpebra. Vejamos os números:

\section{Tabela 2 - Freqüência da questão 89 por sexo/gênero}

\begin{tabular}{lrrrrrr}
\hline \multirow{2}{*}{ Lexia } & \multicolumn{6}{c}{ Sexo/Gênero } \\
\cline { 2 - 7 } & \multicolumn{2}{c}{ Homens } & \multicolumn{2}{c}{ Mulheres } & \multicolumn{2}{c}{ Total } \\
\cline { 2 - 7 } & \multicolumn{1}{c}{ VA } & VR (\%) & \multicolumn{1}{c}{ VA } & \multicolumn{1}{c}{ VR (\%) } & \multicolumn{1}{c}{ VA } & \multicolumn{1}{c}{ VR (\%) } \\
\hline Pálpebra & 1 & 16,67 & 3 & 50,00 & 4 & 33,33 \\
Pipela & 2 & 33,33 & 0 & 0,00 & 2 & 16,67 \\
Pestana & 0 & 0,00 & 1 & 16,67 & 1 & 8,33 \\
Abstenções & 3 & 50,00 & 2 & 33,33 & 5 & 41,67 \\
$\quad$ Total & $\mathbf{6}$ & $\mathbf{1 0 0 , 0 0}$ & $\mathbf{6}$ & $\mathbf{1 0 0 , 0 0}$ & $\mathbf{1 2}$ & $\mathbf{1 0 0 , 0 0}$ \\
\hline
\end{tabular}

Os gênero masculino apresentou baixo percentual de atualização da lexia pálpebra, ao passo que, no feminino, a lexia foi bem mais produtiva, atingindo $50 \%$ das respostas. $\mathrm{O}$ contrário aconteceu com a lexia pipela: nenhuma ocorrência foi registrada entre os sujeitos do 
gênero feminino, enquanto o índice percentual de uso entre os homens foi considerável: 33,3\%. Os dados apontam uma primeira conclusão em relação à variável sexo/gênero: em Iguape, os homens preferem os termos banalizados aos termos técnicos. As mulheres empregam a linguagem de especialidade.

Na tabela abaixo, podemos verificar o uso por faixa etária.

\section{Tabela 3 - Freqüência da questão 89 por faixa etária}

\begin{tabular}{lrrrrrr}
\hline \multirow{2}{*}{ Lexia } & \multicolumn{6}{c}{ Faixa Etária } \\
\cline { 2 - 7 } & \multicolumn{1}{c}{$\mathbf{1 8}$ a 30 anos } & \multicolumn{2}{c}{ 66 anos ou mais } & \multicolumn{2}{c}{ Total } \\
\cline { 2 - 7 } & VA & \multicolumn{1}{c}{ VR (\%) } & \multicolumn{1}{c}{ VA } & \multicolumn{1}{c}{ VR (\%) } & \multicolumn{1}{c}{ VA } & \multicolumn{1}{c}{ VR (\%) } \\
\hline Pálpebra & 4 & 66,67 & 0 & 0,00 & 4 & 33,33 \\
Pipela & 0 & 0,00 & 2 & 33,33 & 2 & 16,67 \\
Pestana & 0 & 0,00 & 1 & 16,67 & 1 & 8,33 \\
Abstenções & 2 & 33,33 & 3 & 50,00 & 5 & 41,67 \\
$\quad$ Total & $\mathbf{6}$ & $\mathbf{1 0 0 , 0 0}$ & $\mathbf{6}$ & $\mathbf{1 0 0 , 0 0}$ & $\mathbf{1 2}$ & $\mathbf{1 0 0 , 0 0}$ \\
\hline
\end{tabular}

O termo pálpebra foi empregado como resposta a esta questão pela maioria dos sujeitos da primeira faixa etária, revelando-se domínio de um repertório de maior grau de especificidade no continuum banalização $\leftrightarrow$ especialização. Os sujeitos da segunda faixa etária não fizeram uso do termo pálpebra, mas foi nessa faixa etária que apareceram as duas ocorrências da lexia pipela, sugerindo que a lexia só está memorizada pelos mais velhos e vem sendo preterida pelos mais jovens. Verifica-se, portanto, que os sujeitos da primeira faixa etária, em Iguape, têm maior domínio do vocabulário técnico-científico.

Vejamos agora como se distribui a lexia estudada nos pontos selecionados.

Tabela 4 - Distribuição das lexias da questão 89 pelos pontos

\begin{tabular}{|c|c|c|c|c|c|c|c|c|}
\hline \multirow{3}{*}{ LEXIA } & \multicolumn{8}{|c|}{ PONTO } \\
\hline & \multicolumn{2}{|c|}{ ICAPARA } & \multicolumn{2}{|c|}{ ROCIO } & \multicolumn{2}{|c|}{ JAIRÊE } & \multicolumn{2}{|c|}{ TOTAL } \\
\hline & VA & VR (\%) & VA & $\operatorname{VR}(\%)$ & VA & $\operatorname{VR}(\%)$ & VA & $\operatorname{VR}(\%)$ \\
\hline Pálpebra & 1 & 25,00 & 2 & 50,00 & 1 & 25,00 & 4 & 33,33 \\
\hline Pipela & 0 & 0,00 & 1 & 25,00 & 1 & 25,00 & 2 & 16,67 \\
\hline Pestana & 0 & 0,00 & 0 & 0,00 & 1 & 25,00 & 1 & 8,33 \\
\hline Abstenções & 3 & 75,00 & 1 & 25,00 & 1 & 25,00 & 5 & 41,67 \\
\hline TOTAL & 4 & 100,00 & 4 & 100,00 & 4 & 100,00 & 12 & 100,00 \\
\hline
\end{tabular}


O Rocio, o bairro mais próximo do centro de Iguape, mais populoso, mais movimentado, foi o que apresentou a maior freqüência de uso do termo pálpebra. Nos outros dois bairros, Icapara e Jairê, de arraigadas tradições caiçaras, bastante afastados do centro, apenas um quarto dos falantes emprega o termo pálpebra. Não por acaso, os moradores daquele bairro têm acesso ao Hospital Municipal de Iguape, enquanto os moradores destes contam apenas com um Posto Médico. Desse modo, concluímos que a realidade extralingüística influiu na vida dos moradores das áreas urbanas, que têm mais acesso a médicos e à rede hospitalar, e, conseqüentemente, refletiu- se no falar concreto, sob a forma de um maior domínio de termos da linguagem médica.

No quadro abaixo, comparamos a ocorrência das variantes em Iguape a outros dois atlas regionais: o Atlas Lingüístico do Paraná - ALPR (1994) e o Atlas Lingüístico de Mato Grosso do Sul - ALMS (2007), em que a questão aparece.

\section{Tabela 5 - Comparação da variação lexical da questão 89: Iguape - Outros atlas regionais}

\begin{tabular}{lcccc}
\hline \multirow{2}{*}{ Lexia } & \multirow{2}{*}{ Município de Iguape } & \multicolumn{2}{c}{ Atlas } & \multirow{2}{*}{ Total } \\
\cline { 3 - 4 } & & ALPR & ALMS & \\
\hline Pestana (dos olhos) & $\mathbf{X}$ & $\mathbf{X}$ & $\mathbf{X}$ & $\mathbf{3}$ \\
Pálpebra & $\mathbf{X}$ & $\mathbf{X}$ & $\mathbf{X}$ & $\mathbf{2}$ \\
Pestana & & $\mathbf{X}$ & $\mathbf{X}$ & $\mathbf{2}$ \\
Capela (do olho) & & $\mathbf{X}$ & $\mathbf{X}$ & $\mathbf{2}$ \\
Capa (do olho) & & $\mathbf{X}$ & $\mathbf{X}$ & $\mathbf{2}$ \\
Pele (do olho) & & $\mathbf{X}$ & $\mathbf{X}$ & $\mathbf{2}$ \\
Couro (do olho) & $\mathbf{X}$ & & & $\mathbf{1}$ \\
Pipela & & $\mathbf{X}$ & & $\mathbf{1}$ \\
Sobrancelha & $\mathbf{3}$ & $\mathbf{6}$ & $\mathbf{6}$ & \\
\hline \multicolumn{1}{c}{ Total } & & &
\end{tabular}

\section{Análise de traços semânticos}

Iniciamos a análise de traços semânticos pela pesquisa sobre a linguagem de especialidade, uma vez que pálpebra é um termo técnico-científico.

As características de uma linguagem de especialidade, resumidas por Cabré (1993, p.135) são: i) constituem conjuntos "especializados", seja pela temática, pela experiência, 
pelo âmbito de uso ou por seus usuários; ii) apresentam-se como um conjunto com características inter-relacionadas, não como fenômenos isolados; e iii) mantêm a função comunicativa como predominante, acima de outras funções complementares.

Guilbert (apud DUBOIS,1978, p.187) salienta que a relação semântica no vocabulário técnico é diferente da que está no vocabulário geral, pelo fato de muitas vezes nele ocorrer a polissemia, enquanto aquele é geralmente monossêmico.

Consultamos o dicionário de medicina de Braier (1964), em espanhol, e dicionários gerais de língua portuguesa, em que encontramos as seguintes acepções de pálpebra:

- párpado: m. Cada uno de los dos velos movibles, superior e inferior, formados de piel, músculo y cartilago, los cuales al aproximarse entre si cubren completamente la parte anterior del globo ocular (BRAIER, 1964, p. 973).

- pálpebra sf. (1670 cf AFLuz) ANAT véu musculomembranoso que recobre parcialmente o olho na parte superior e na parte inferior, destinado a protegê-lo (c) ETIM lat. pálpebra,ae e palpebrae, arum, 'id.', ver palp- NOÇÃO de 'pálpebra', usar antepos. blefar(o)- (HOUAISS, 2001, p. 2113).

- pálpebra [Do lat. pálpebra] sf. Anat. Cada uma das duas pregas móveis, uma superior e outra inferior, dotada de cílios, e que protege a superfície anterior de cada globo ocular. (FERREIRA, 2002, p. 1475).

- pálpebra sf. 'membrana móvel que cobre o globo ocular' 1813. Do lat. pálpebra,-ae// palpebr AL 1858. Do lat. tardio palpebralis. (CUNHA, 2000, p. 574).

Como termo técnico que é, 'pálpebra' pertence ao léxico da linguagem de especialidade médica. Segundo informa Cabré (1993, p.131), as linguagens de especialidade não têm, em teoria, termos polissêmicos. Na verdade, diremos que pálpebra é monossemêmico, ou seja, tem apenas uma acepção, um semema.

Do semema de pálpebra, definido de várias maneiras e por diversas combinações sêmicas, recolhido nos vários dicionários, destacamos, na definição de Ferreira (2004), o 
sema 'dotada de cílios' $\left(S_{1}\right)$. O sema inerente $S_{1}$ é proveniente do sistema funcional da língua, é denotativo, distintivo, definitório e universal, típico, portanto, de uma linguagem de especialidade (RASTIER, 1987, p.44).

O sema $S_{1}$ nos interessa porque vai ser alvo de uma atualização seletiva de traços que, por muitas estratégias de inferências possíveis, vai produzir a variante pestana. Segundo Houaiss (2003, p. 2201), pestana é o mesmo que cílio. De acordo com Rastier (1987, p.11), diversos leitores chegam a resultados diferentes quanto à produção/interpretação devido à disparidade de seus conhecimentos enciclopédicos. As inferências percorrem diferentes caminhos, de acordo com a competência interpretativa do sujeito ou a história da comunidade. Associando o referente (pestana) ao sema 'dotada de cílios', o sujeito (e toda a comunidade) realizou a variante pestana, neste caso, um item lexical de um socioleto.

As outras formas selecionadas pelos sujeitos são lexias geradas pelo próprio núcleo sêmico de pálpebra: capa, capela, pele e couro do olho, que remetem a véu, membrana, prega do olho, do globo ocular. Elas põem em relevo a função da pálpebra que é velar, cobrir o olho, expressa pelos semas 'que cobre o globo ocular', 'que recobre parcialmente o olho', 'cubren completamente (...) globo ocular'. Além disso, a pálpebra protege o olho, como indicam os traços ‘destinado a protegê-lo' e 'que protege a superfície anterior de cada globo ocular'.

A função que exerce a pálpebra ao velar, cobrir os olhos, identifica-se com o hábito de cobrir o rosto, ou toda a cabeça com um véu. Leia-se este trecho da Bíblia, recolhido por Cascudo (1979, p.241):

Fitar de frente os olhos tornou-se uso restrito na ambivalência amor e medo, amor pela atração da obediência e medo à contaminação maléfica. Moisés cobriu o rosto para não olhar Iavé (Êxodo, III, 6) e mesmo que Deus lhe falasse como amigo, cara a cara, avisou-o de que nenhum homem poderia ver-lhe o rosto sem morrer (Exodo, XXXIII, 20) e Moisés, tendo visto a divina face, ficou com a sua resplandecente e, para não atemorizar os hebreus, velou-se (Êxodo, XXXIV, 29-30, 33-35).

Recolhemos alguns comentários feitos pelos sujeitos entrevistados no Paraná, constantes do ALPR, referentes a esta questão: 
03 (inf. A): Hesitando, comentou: “a mãe fala o 'véu do olho', né”.

26 (inf. A): "é capela do zóio".

29 (inf. B): Na repergunta: “capelinha do zóio”.

30 (inf. A): "isso tem que sê o coro do zóio".

31 (inf. B): Inicialmente: "sombrancelha". No teste de identificação para capela registrou: "dizem capela mesmo, capela do olho mesmo".

65 (inf. A): A resposta completa foi: "esse aqui é cilo. Esse aqui não sei, é uma pele mas não sei o nome ... capela do zolho".

A lexia sobrancelha, tal como consta do ALPR, talvez tenha sido selecionada em Iguape por extensão, proximidade. Já para a forma pipela, registrada apenas em Iguape, não encontramos explicação. Será dissimilação de capela?

\subsubsection{Cisco}

QUESTÃO 90 - ... alguma coisinha que cai no olho e fica incomodando?

\section{Freqüiência e distribuição}

A tabela a seguir reúne as respostas à questão $\mathrm{n}^{\circ} 90$ :

\section{Tabela 6 - Freqüência geral da questão 90 - Iguape}

\begin{tabular}{lrr}
\hline \multirow{2}{*}{ Lexia } & \multicolumn{2}{c}{ Freqüência } \\
\cline { 2 - 3 } & \multicolumn{1}{c}{ VA } & \multicolumn{1}{c}{ VR (\%) } \\
\hline Cisco & 9 & 75,00 \\
Poeira & 1 & 8,33 \\
Abstenções & 2 & 16,67 \\
$\quad$ Total & $\mathbf{1 2}$ & $\mathbf{1 0 0 , 0 0}$ \\
\hline
\end{tabular}

É quase geral o uso da lexia cisco em Iguape, para referir a partícula que cai no olho e incomoda bastante. 
Os sujeitos de ambos os gêneros usam indistintamente a lexia cisco. Vejamos os números:

Tabela 7 - Freqüiência da questão 90 por sexo/gênero

\begin{tabular}{lrrrrrr}
\hline \multirow{2}{*}{ Lexia } & \multicolumn{6}{c}{ Sexo/Gênero } \\
\cline { 2 - 7 } & \multicolumn{2}{c}{ Homens } & \multicolumn{2}{c}{ Mulheres } & \multicolumn{2}{c}{ Total } \\
\cline { 2 - 7 } & \multicolumn{1}{c}{ VA } & \multicolumn{1}{c}{ VR (\%) } & \multicolumn{1}{c}{ VA } & \multicolumn{1}{c}{ VR (\%) } & \multicolumn{1}{c}{ VA } & \multicolumn{1}{c}{ VR (\%) } \\
\hline Cisco & 5 & 83,33 & 4 & 66,67 & 9 & 75,00 \\
Poeira & 0 & 0,00 & 1 & 16,67 & 1 & 8,33 \\
Abstenções & 1 & 16,67 & 1 & 16,67 & 2 & 16,67 \\
$\quad$ Total & $\mathbf{6}$ & $\mathbf{1 0 0 , 0 0}$ & $\mathbf{6}$ & $\mathbf{1 0 0 , 0 0}$ & $\mathbf{1 2}$ & $\mathbf{1 0 0 , 0 0}$ \\
\hline
\end{tabular}

Na tabela abaixo, podemos verificar o uso por faixa etária.

Tabela 8 - Freqüência da questão 90 por faixa etária

\begin{tabular}{lrrrrrr}
\hline \multirow{2}{*}{ Lexia } & \multicolumn{6}{c}{ Faixa Etária } \\
\cline { 2 - 7 } & \multicolumn{2}{c}{$\mathbf{1 8}$ a 30 anos } & \multicolumn{2}{c}{ 66 anos ou mais } & \multicolumn{2}{c}{ Total } \\
\cline { 2 - 7 } & \multicolumn{1}{c}{ VA } & \multicolumn{1}{c}{ VR (\%) } & \multicolumn{1}{c}{ VA } & \multicolumn{1}{c}{ VR (\%) } & \multicolumn{1}{c}{ VA } & \multicolumn{1}{c}{ VR (\%) } \\
\hline Cisco & 4 & 66,67 & 5 & 83,33 & 9 & 75,00 \\
Poeira & 0 & 0,00 & 1 & 16,67 & 1 & 8,33 \\
Abstenções & 2 & 33,33 & 0 & 0,00 & 2 & 16,67 \\
$\quad$ Total & $\mathbf{6}$ & $\mathbf{1 0 0 , 0 0}$ & $\mathbf{6}$ & $\mathbf{1 0 0 , 0 0}$ & $\mathbf{1 2}$ & $\mathbf{1 0 0 , 0 0}$ \\
\hline
\end{tabular}

A lexia cisco foi selecionada pela maioria dos sujeitos das duas faixas etárias, revelando bastante vitalidade entre os mais idosos, mas também boa aceitação entre os mais jovens. Ou seja, a lexia está memorizada por falantes/ouvintes de ambas as faixas etárias.

Vejamos agora como se distribui a lexia estudada nos pontos selecionados.

Tabela 9 - Distribuição das lexias da questão 90 pelos pontos

\begin{tabular}{lrrrrrrrr}
\hline \multirow{2}{*}{ LEXIA } & \multicolumn{8}{c}{ PONTO } \\
\cline { 2 - 9 } & \multicolumn{2}{c}{ ICAPARA } & \multicolumn{2}{c}{ ROCIO } & \multicolumn{2}{c}{ JAIR } & \multicolumn{2}{c}{ TOTAL } \\
\cline { 2 - 9 } & VA & VR (\%) & \multicolumn{1}{c}{ VA } & \multicolumn{1}{c}{ VR (\%) } & \multicolumn{1}{c}{ VA } & \multicolumn{1}{c}{ VR (\%) } & \multicolumn{1}{c}{ VA } & \multicolumn{1}{c}{ VR (\%) } \\
\hline Cisco & 3 & 75,00 & 3 & 75,00 & 3 & 75,00 & 9 & 75,00 \\
Poeira & 1 & 25,00 & 0 & 0,00 & 0 & 0,00 & 1 & 8,33 \\
Abstenções & 0 & 0,00 & 1 & 25,00 & 1 & 25,00 & 2 & 16,67 \\
TOTAL & $\mathbf{4}$ & $\mathbf{1 0 0 , 0 0}$ & $\mathbf{4}$ & $\mathbf{1 0 0 , 0 0}$ & $\mathbf{4}$ & $\mathbf{1 0 0 , 0 0}$ & $\mathbf{1 2}$ & $\mathbf{1 0 0 , 0 0}$ \\
\hline
\end{tabular}


Nos três bairros, Icapara, Rocio e Jairê, emprega-se majoritária e igualmente a forma cisco, constituindo-se em norma semântico-lexical da localidade.

No quadro abaixo, comparamos a ocorrência das variantes em Iguape com outro atlas regional: o Atlas Lingüístico da Paraíba - ALPB (1984), o único dos atlas pesquisados em que encontramos essa questão.

Tabela 10 - Comparação da variação lexical da questão 90: Iguape - Outros atlas regionais

\begin{tabular}{cccc}
\hline Lexia & Município de Iguape & Atlas ALPB & Total \\
\hline Cisco & $\mathbf{X}$ & $\mathbf{X}$ & $\mathbf{2}$ \\
Poeira & $\mathbf{X}$ & & $\mathbf{1}$ \\
Argueiro & & $\mathbf{X}$ & $\mathbf{1}$ \\
TOTAL & $\mathbf{2}$ & $\mathbf{2}$ & \\
\hline
\end{tabular}

Como podemos observar, a lexia cisco ocorre em Iguape e na Paraíba. A forma variante poeira ocorre somente em Iguape, e argueiro é variante lexical apenas na Paraíba.

\section{Análise de traços semânticos}

Partindo para a análise de traços semânticos relativos à lexia cisco, fomos procurar em dicionários gerais de língua portuguesa suas acepções:

- cisco 1 pó ou miudezas de carvão 2 lixo 3 material sólido e heterogêneo (gravetos, ramos, algas etc.) trazido pelas enxurradas 4 design. comum às aparas miúdas $5 \mathrm{~B}$ partícula ou grânulo (de poeira etc.) que entra acidentalmente no olho, argueiro 6 MNH m.q. CARUMA ('folha', 'certa quantidade') 7 MÚS conjunto de instrumentistas na folia de reis (HOUAISS, 2001, p. 730).

- cisco [De or. obscura] S.m. 1 pó ou miudezas de carvão 2 lixo, varredura 3 ramos, gravetos, etc., arrastados pelas enxurradas 4 Bras. Leve partícula de qualquer corpo caída especialmente no olho. [Sin.(No N e em Portugal): argueiro]*Como cisco. Em grande quantidade: gente como cisco (FERREIRA, dic. eletr.). 
- cisco 'pó, lixo, varredura' XVI. De origem controvertida // ciscar R vb. 'limpar, revolver (o cisco)’ 1844; ‘fugir, escapulir’ XVI (CUNHA, 1986, p. 186).

Dentre os vários sememas de cisco, o uso que nos interessa está contemplado na acepção 5, de Houaiss, e 4, de Ferreira. A começar pela própria pergunta, “... alguma coisinha que cai no olho e incomoda?", a rede semêmica de cisco apresenta uma série de semas inerentes que estabelecem relações de identidade entre os sememas, denotando a idéia recorrente do diminutivo, como 'coisinhas', 'miudezas', 'gravetos', 'aparas miúdas', 'partícula' e 'grânulo'.

A lexia coisinhas, apesar de se apresentar sob a forma diminutiva, é arquilexema de todas as outras formas citadas. Quer dizer, engloba todos os semas ou traços semânticos de 'miudezas', 'gravetos', 'aparas miúdas', 'partícula' e 'grânulo'.

As recorrências induzem a relações de equivalência entre os vários sememas de cisco, instaurando-se a isotopia. A isotopia é uma forma de combinatória sêmica, um efeito da combinação de semas, segundo Rastier (1987, p.11). Daí Houaiss registrar que "Corominas acha mais verossímil tratar-se de uma criação expressiva, lembrando comparações que se fazem com o lat. ciccus, $i$ 'coisa insignificante', tb relacionado (só indiretamente) com o esp. chico "de tamanho pequeno"”.

Uma minoria empregou a lexia poeira como resposta à questão. Como vemos na definição dada por Houaiss (2001), poeira é um dos semas aferentes de cisco, pode ficar latente e emergir a qualquer momento do processo da significação. Poeira emerge dentre os demais semas por inferência, por uma associação bastante previsível, desvelada pelo filólogo: 'partícula ou grânulo (de poeira etc)'. A isotopia que a revela provém de normas socioletais, isto é, traduz uma expectativa socializada.

Houaiss (p. 2245), quanto ao verbete poeira, dá a seguinte definição: “qualquer substância reduzida a pó muito fino". 
Cunha (p. 616), analisando etimologicamente a lexia pó, anota: do lat. *pulus, de *pulvus (cláss. pulvis,-veris) //poeira XVI//. Cisco é, na interpretação dos sujeitos que a selecionaram, qualquer substância pulverizada, ou seja, reduzida a pó muito fino, que se instala no olho (e causa grande incômodo).

Como pudemos constatar no ALPB, a forma argueiro é uma variante de cisco. Ferreira (2004) registra a variante, mas apenas assinala que é sinônimo de cisco no norte do Brasil (N), sem determinar a localidade, e em Portugal.

Cascudo (1979, p. 22) traz maiores informações sobre o argueiro, produto da história ou do uso popular:

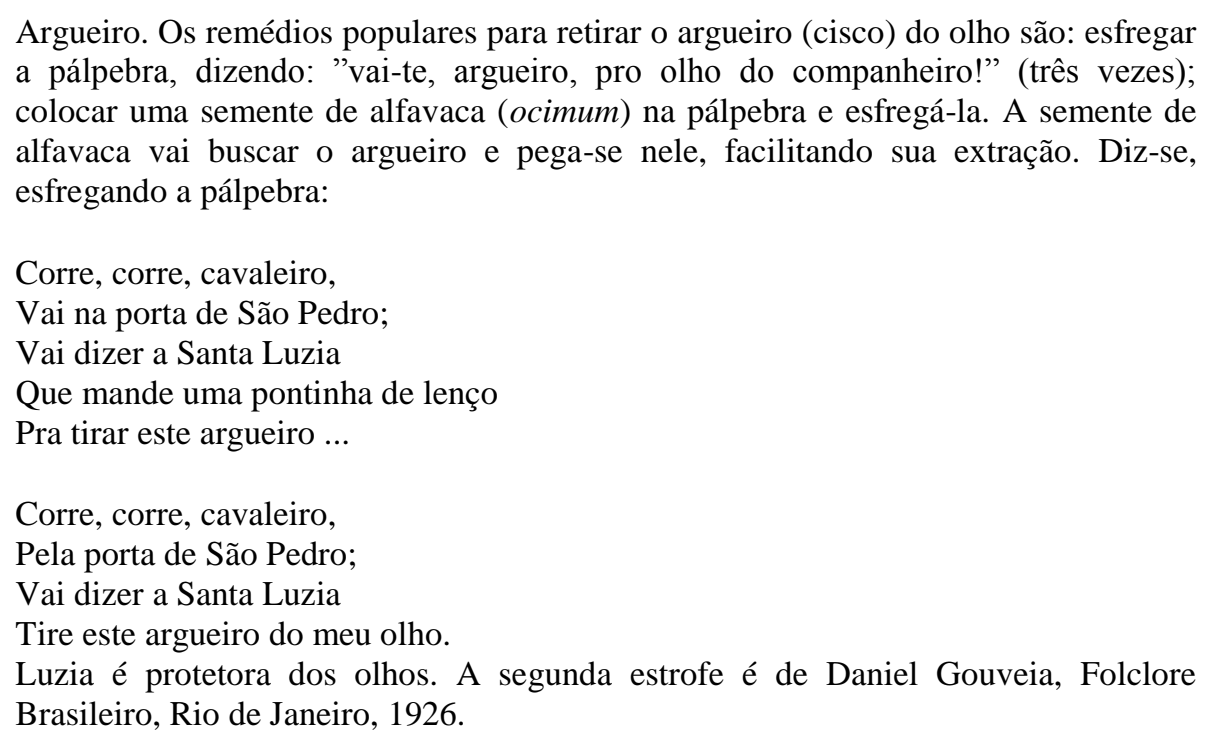

Para as moléstias de olhos, ou o desconforto causado aos olhos por um cisco, pode-se apelar para a proteção de um amuleto, como acrescenta Cascudo (1973, p.240): "Por uma convergência natural os olhos-de-santa-luzia, para as moléstias de olhos, representações dos glóbulos oculares da santa, em ouro ou prata, trazidos ao pescoço, significam amuleto contra o fascínio ou a má sorte.” 


\subsubsection{Cego de um Olho}

QUESTÃO 91 ... a pessoa que só enxerga com um olho?

\section{Freqüiência e distribuição}

A tabela a seguir reúne as respostas à questão sobre cego de um olho, colhidas em Iguape:

Tabela 11 - Freqüência geral da questão 91- Iguape

\begin{tabular}{lrr}
\hline \multirow{2}{*}{ Lexia } & \multicolumn{2}{c}{ Freqüência } \\
\cline { 2 - 3 } & \multicolumn{1}{c}{ VA } & \multicolumn{1}{c}{ VR (\%) } \\
\hline Caolho & 6 & 50,00 \\
Picego & 3 & 25,00 \\
Cego de um olho & 2 & 16,67 \\
Abstenções & 1 & 8,33 \\
\multicolumn{1}{c}{ TOTAL } & $\mathbf{1 2}$ & $\mathbf{1 0 0 , 0 0}$ \\
\hline
\end{tabular}

É alta a freqüência de uso da lexia caolho, em Iguape, para designar 'a pessoa que só enxerga com um olho'. Para metade dos iguapenses pesquisados, ela é de fácil decodificação, faz parte do vocabulário ativo. A lexia picego tem freqüência relativamente alta em Iguape, se considerarmos que ela não ocorre em nenhum outro atlas consultado.

Uma pequena parte empregou a lexia complexa cego de um olho para responder à questão n 91.

Em relação à variável sexo/gênero, há bastante equilíbrio entre homens e mulheres, como vemos na tabela abaixo: 
Tabela 12 - Freqüência da questão 91 por sexo/gênero

\begin{tabular}{lrrrrrr}
\hline \multirow{2}{*}{ Lexia } & \multicolumn{6}{c}{ Sexo/Gênero } \\
\cline { 2 - 7 } & \multicolumn{2}{c}{ Homens } & \multicolumn{2}{c}{ Mulheres } & \multicolumn{2}{c}{ Total } \\
\cline { 2 - 7 } & VA & \multicolumn{1}{c}{ VR (\%) } & \multicolumn{1}{c}{ VA } & VR (\%) & \multicolumn{1}{c}{ VA } & \multicolumn{1}{c}{ VR (\%) } \\
\hline Caolho & 3 & 50,00 & 3 & 50,00 & 6 & 50,00 \\
Picego & 2 & 33,33 & 1 & 16,67 & 3 & 25,00 \\
Cego de um & & & & & & \\
olho & 1 & 16,67 & 1 & 16,67 & 2 & 16,67 \\
Abstenções & 0 & 0,00 & 1 & 16,67 & 1 & 8,33 \\
$\quad$ & $\mathbf{6}$ & $\mathbf{1 0 0 , 0 0}$ & $\mathbf{6}$ & $\mathbf{1 0 0 , 0 0}$ & $\mathbf{1 2}$ & $\mathbf{1 0 0 , 0 0}$ \\
\hline
\end{tabular}

Na tabela abaixo, podemos verificar o uso por faixa etária.

Tabela 13 - Frequiência da questão 91 por faixa etária

\begin{tabular}{lrrrrrr}
\hline \multirow{2}{*}{ Lexia } & \multicolumn{5}{c}{ Faixa Etária } \\
\cline { 2 - 7 } & \multicolumn{1}{c}{$\mathbf{1 8}$ a 30 anos } & \multicolumn{6}{c}{ 66 anos ou mais } & \multicolumn{2}{c}{ Total } \\
\cline { 2 - 7 } & \multicolumn{1}{c}{ VA } & VR (\%) & \multicolumn{1}{c}{ VA } & VR (\%) & \multicolumn{1}{c}{ VA } & \multicolumn{1}{c}{ VR (\%) } \\
\hline Caolho & 4 & 66,67 & 2 & 33,33 & 6 & 50,00 \\
Picego & 1 & 16,67 & 2 & 33,33 & 3 & 25,00 \\
Cego de um & & & & & & \\
olho & 0 & 0,00 & 2 & 33,33 & 2 & 16,67 \\
Abstenções & 1 & 16,67 & 0 & 0,00 & 1 & 8,33 \\
$\quad$ & $\mathbf{6}$ & $\mathbf{1 0 0 , 0 0}$ & $\mathbf{6}$ & $\mathbf{1 0 0 , 0 0}$ & $\mathbf{1 2}$ & $\mathbf{1 0 0 , 0 0}$ \\
\hline
\end{tabular}

A lexia caolho foi empregada preferencialmente pelos sujeitos da primeira faixa etária, tendo a forma bastante vitalidade também entre os mais idosos. Ou seja, a lexia está memorizada por sujeitos das duas faixas etárias.

Vejamos agora como se distribui a lexia estudada nos pontos selecionados.

Tabela 14 - Distribuição das lexias da questão 91 pelos pontos

\begin{tabular}{|c|c|c|c|c|c|c|c|c|}
\hline \multirow{3}{*}{ Lexia } & \multicolumn{8}{|c|}{ Ponto } \\
\hline & \multicolumn{2}{|c|}{ Icapara } & \multicolumn{2}{|c|}{ Rocio } & \multicolumn{2}{|c|}{ Jairê } & \multicolumn{2}{|c|}{ Total } \\
\hline & VA & $\operatorname{VR}(\%)$ & VA & $\operatorname{VR}(\%)$ & VA & $\operatorname{VR}(\%)$ & VA & $\operatorname{VR}(\%)$ \\
\hline Caolho & 2 & 50,00 & 1 & 25,00 & 3 & 75,00 & 6 & 50,00 \\
\hline Picego & 2 & 50,00 & 0 & 0,00 & 1 & 25,00 & 3 & 25,00 \\
\hline Cego de um & & & & & & & & \\
\hline olho & 0 & 0,00 & 2 & 50,00 & 0 & 0,00 & 2 & 16,67 \\
\hline Abstenções & 0 & 0,00 & 1 & 25,00 & 0 & 0,00 & 1 & 8,33 \\
\hline Total & 4 & 100,00 & 4 & 100,00 & 4 & 100,00 & 12 & 100,00 \\
\hline
\end{tabular}


Nos bairros da zona rural, Icapara e Jairê, que, como já dissemos, são mais distantes do centro de Iguape, e conservam arraigadas tradições caiçaras, emprega-se majoritariamente a forma caolho. No Rocio, bairro da zona urbana, grande e populoso, na falta de uma forma socializada que contemplasse o significado contido na pergunta, a maioria optou pela lexia complexa transparente, 'cego de um olho', que descreve o referente. A variante picego, que foi atualizada nos dois bairros da zona rural, no Rocio não apresentou nenhuma ocorrência.

No quadro abaixo, comparamos a ocorrência das variantes em Iguape a outro atlas regional: o Atlas Lingüístico do Mato Grosso do Sul - ALMS, único dos atlas regionais pesquisados em que encontramos essa questão.

Tabela 15 - Comparação da variação lexical da questão 91: Iguape - Outros atlas regionais

\begin{tabular}{lccc}
\hline Lexia & Município de Iguape & Atlas ALMS & Total \\
\hline Caolho & $\mathbf{X}$ & $\mathbf{X}$ & $\mathbf{2}$ \\
Cego de um olho & $\mathbf{X}$ & $\mathbf{X}$ & $\mathbf{2}$ \\
Picego & $\mathbf{X}$ & $\mathbf{X}$ & $\mathbf{1}$ \\
Zarolho & & $\mathbf{X}$ & $\mathbf{1}$ \\
Vesgo & & $\mathbf{4}$ & \\
\multicolumn{1}{c}{ Total } & $\mathbf{3}$ &
\end{tabular}

Como podemos observar, as lexias caolho e cego de um olho ocorrem em Iguape e no Mato Grosso do Sul. A forma variante picego ocorre somente em Iguape, e zarolho e vesgo são variantes lexicais apenas no Mato Grosso do Sul.

\section{Análise de traços semânticos}

Buscando subsídios para a análise qualitativa nos dicionários gerais de língua portuguesa, encontramos as seguintes acepções para caolho:

- caolho (1899 cf CF) 1 que ou quem não tem um dos olhos 2 m.q. estrábico @ ETM segundo Nascentes e AGC, prov. voc. híbrido, formado do quimb. $k a$ 'pequeno' e do port. olho ¥ SIN/VAR ver sinonímia de estrábico (HOUAISS, 2001, p. 605). 
- caolho 1 cego de um olho ou estrábico: Começou a namorar a irmã caolha de seu amigo. S.m. 2 pessoa caolha ou estrábica: Como é que um caolho faz mira? (BORBA, 2002, p. 233).

- caolho [Do quimb. Ka, 'pequeno', + olho(ô) Adj. s.m. Bras. 1 v. estrábico (2 e 4) 2 v. zarolho[1 e 4] (FERREIRA, 2004, p. 605).

Neste caso, a pergunta foi muito bem formulada e contempla os semas do semema da definição de Houaiss e os de Borba: a pessoa que só enxerga com um olho, ou é porque só tem um olho, ou porque é cega de um dos olhos. O núcleo sêmico é exatamente esse: cego de um olho. O verbete estrábico tem tratamento de parassinônimo de caolho nas definições acima, mas não é assim interpretado pelo vulgo. Será motivo de estudo na questão sobre vesgo.

A lexia picego, de origem obscura, foi atualizada por inferência a partir dos semas inerentes de caolho: se só enxerga com um olho, infere-se que é uma "pessoa que enxerga mal, que é míope ou vesga", como se lê na definição dessa lexia em Houaiss (2001, p.2207). Encontramos a variante picega lexicalizada em Ferreira (dic. eletr.) e em Diegues (2005, p. 209), na acepção “pessoa que só enxerga com um olho”.

A lexia complexa cego de um olho é o núcleo sêmico do semema de caolho, definido acima em Borba. Para disjungir-se de caolho e daí alçar-se à condição de lexia, o traço sêmico cego de um olho depende apenas da competência interpretativa do falante. Ela emerge do conjunto de semas como o traço distintivo mais transparente e marcante, passando a nomear o referente diretamente, e não mais como qualidade in re, inerente ao objeto.

A significação original da lexia caolho, segundo sua origem etimológica, provavelmente hibridismo do quimbundo $k a$ + o português olho , resultado 'olho pequeno', parece ter sofrido contaminação semântica de outras lexias referentes a anomalias ou deficiência dos olhos. 
A importância dada aos olhos desde a Antigüidade, é destacada por Cascudo (1979, p. 281):

O mais atroz castigo e a maior tortura é o arrancamento dos olhos ${ }^{2}$, tornando o supliciado um infra-homem, dependente da vontade alheia.

As enfermidades e defeitos físicos não são bem-vindos pelos homens e, por isso, até mesmo as designações para essas doenças e deficiências são evitadas. Acredita-se que são estigmas lançados por Deus como castigo, provação.

Podem ser encontradas no Antigo Testamento, passagens que sustentam essa crença:

Deuteronômio, 5:9 - "Eu sou o Senhor teu Deus, Deus zeloso, que castigo a iniqüidade dos pais sobre os filhos até à terceira e quarta geração daqueles que me aborrecem". E no Novo Testamento - "E, passando Jesus, viu um homem cego de nascença; e os seus discípulos perguntaram-lhe: Mestre, quem pecou, este ou seus pais, para que nascesse cego?'(Jo, 9:12) (apud GUÉRIOS, 1979, p. 138).

Guérios (1979, p.143) sustenta que o lat. orbus, primit. "privado de" e ab oculis, 'sem olhos", são expressões eufemizantes que, em muitas regiões da România, vieram a substituir caecus. Ele acredita, ainda, que o eufemismo aplicado a um defeito físico consiste em se acrescentar um sufixo diminutivo ao nome da parte do corpo humano. E dá os seguintes exemplos: maneta, perneta, orelhote, nariguete, cegueta, manquitola, coxelas, beiçola, careca, cambeta ou cambotas, etc.

Em nenhuma das línguas românicas se sentiu a necessidade de substituir oculus por outra voz, afirma Rohlfs (1979, p.227), e ela se conservou com vitalidade.

$\begin{array}{llll}\text { Dalm. } & \text { vaclo } & \text { Prov. } & \text { olh } \\ \text { Sardo } & \text { ogru }(\text { ogu }) & \text { Cat. } & \text { ull } \\ \text { It. } & \text { occhio } & \text { Fr. } & \text { oeil } \\ \text { Rum. } & \text { ochiu } & \text { Esp. } & \text { ojo } \\ \text { Rét. } & \text { ögl } & \text { Port. } & \text { olho }\end{array}$

2 Segundo o autor cegar era pena clássica aos sacrílegos e adúlteros (gregos), perjuros, traidores, moedeiros falsos, entre os germânicos, ainda aplicada na Alemanha do século XV. Na Espanha o Fuero Juzgo destinava-a aos rebeldes traidores mas as Partidas aboliram (ley 6, tit. 31, Partida 7): porque la cara del home fizo Deus á su semejança. Completava a condenação, quando ligada aos crimes políticos e de traição ao rei, a castração. Corrente na Rússia asiática nos finais do século XIX e primeira década do XX. Comuníssimo na África no século XX, castigo de ambição política ou rebeldia. Faziam passar diante dos olhos uma lâmina ardente ou arrancavam os glóbulos oculares. Oriente. África Setentrional. 


\subsubsection{Vesgo}

QUESTÃO 92 - ... a pessoa que tem os olhos voltados para direções diferentes? Completar com um gesto dos dedos.

\section{Freqüência e distribuição}

A tabela a seguir reúne as respostas à questão nº 92 , registradas em Iguape:

Tabela 16 - Freqüência geral da questão 92- Iguape

\begin{tabular}{lrr}
\hline \multirow{2}{*}{ Lexia } & \multicolumn{2}{c}{ Freqüência } \\
\cline { 2 - 3 } & VA & \multicolumn{1}{c}{ VR (\%) } \\
\hline Vesgo & 10 & 83,33 \\
Estrábico & 1 & 8,33 \\
Abstenções & 1 & 8,33 \\
$\quad$ Total & $\mathbf{1 2}$ & $\mathbf{1 0 0 , 0 0}$ \\
\hline
\end{tabular}

Quase todos os falantes/ouvintes usaram a lexia vesgo, em Iguape, para referir a 'pessoa que tem os olhos voltados para direções diferentes'.

Os sujeitos de ambos os gêneros usam indistintamente a lexia vesgo. Vejamos os números:

Tabela 17 - Freqüiência da questão 92 por sexo/gênero

\begin{tabular}{lrrrrrr}
\hline \multirow{2}{*}{ Lexia } & \multicolumn{6}{c}{ Sexo/Gênero } \\
\cline { 2 - 7 } & \multicolumn{2}{c}{ Homens } & \multicolumn{2}{c}{ Mulheres } & \multicolumn{2}{c}{ Total } \\
\cline { 2 - 7 } & \multicolumn{1}{c}{ VA } & \multicolumn{1}{c}{ VR (\%) } & \multicolumn{1}{c}{ VA } & \multicolumn{1}{c}{ VR (\%) } & \multicolumn{1}{c}{ VA } & \multicolumn{1}{c}{ VR (\%) } \\
\hline Vesgo & 5 & 83,33 & 5 & 83,33 & 10 & 83,33 \\
Estrábico & 1 & 16,67 & 0 & 0,00 & 1 & 8,33 \\
Abstenções & 0 & 0,00 & 1 & 16,67 & 1 & 8,33 \\
$\quad$ Total & $\mathbf{6}$ & $\mathbf{1 0 0 , 0 0}$ & $\mathbf{6}$ & $\mathbf{1 0 0 , 0 0}$ & $\mathbf{1 2}$ & $\mathbf{1 0 0 , 0 0}$ \\
\hline
\end{tabular}

Na tabela abaixo, podemos verificar o uso por faixa etária. 
Tabela 18 - Frequiência da questão 92 por faixa etária

\begin{tabular}{lrrrrrr}
\hline \multirow{2}{*}{ Lexia } & \multicolumn{6}{c}{ Faixa Etária } \\
\cline { 2 - 7 } & \multicolumn{2}{c}{$\mathbf{1 8}$ a 30 anos } & \multicolumn{3}{c}{ 66 anos ou mais } & \multicolumn{2}{c}{ Total } \\
\cline { 2 - 7 } & \multicolumn{1}{c}{ VA } & \multicolumn{1}{c}{ VR $(\boldsymbol{\%})$} & \multicolumn{1}{c}{ VA } & \multicolumn{1}{c}{ VR (\%) } & \multicolumn{1}{c}{ VA } & \multicolumn{1}{c}{ VR (\%) } \\
\hline Vesgo & 4 & 66,67 & 6 & 100,00 & 10 & 83,33 \\
Estrábico & 1 & 16,67 & 0 & 0,00 & 1 & 8,33 \\
Abstenções & 1 & 16,67 & 0 & 0,00 & 1 & 8,33 \\
$\quad$ Total & $\mathbf{6}$ & $\mathbf{1 0 0 , 0 0}$ & $\mathbf{6}$ & $\mathbf{1 0 0 , 0 0}$ & $\mathbf{1 2}$ & $\mathbf{1 0 0 , 0 0}$ \\
\hline
\end{tabular}

A lexia vesgo também foi atualizada pela maioria dos sujeitos das duas faixas etárias, revelando bastante prestígio da forma entre os mais idosos, mas também boa aceitação entre os mais jovens.

Vejamos agora como se distribui a lexia estudada nos pontos selecionados.

Tabela 19 - Distribuição das lexias da questão 92 pelos pontos

\begin{tabular}{lrrrrrrrr}
\hline \multirow{2}{*}{ Lexia } & \multicolumn{10}{c}{ Ponto } \\
\cline { 2 - 10 } & \multicolumn{2}{c}{ Icapara } & \multicolumn{2}{c}{ Rocio } & \multicolumn{2}{c}{ Jairê } & \multicolumn{2}{c}{ Total } \\
\cline { 2 - 10 } & VA & \multicolumn{1}{c}{ VR (\%) } & \multicolumn{1}{c}{ VA } & \multicolumn{1}{c}{ VR (\%) } & VA & VR (\%) & \multicolumn{1}{c}{ VA } & \multicolumn{1}{c}{ VR (\%) } \\
\hline Vesgo & 4 & 100,00 & 3 & 75,00 & 3 & 75,00 & 10 & 83,33 \\
Estrábico & 0 & 0,00 & 1 & 25,00 & 0 & 0,00 & 1 & 8,33 \\
Abstenções & 0 & 0,00 & 0 & 0,00 & 1 & 25,00 & 1 & 8,33 \\
TOTAL & $\mathbf{4}$ & $\mathbf{1 0 0 , 0 0}$ & $\mathbf{4}$ & $\mathbf{1 0 0 , 0 0}$ & $\mathbf{4}$ & $\mathbf{1 0 0 , 0 0}$ & $\mathbf{1 2}$ & $\mathbf{1 0 0 , 0 0}$ \\
\hline
\end{tabular}

Nos três bairros, Icapara, Rocio e Jairê emprega-se majoritariamente a forma vesgo, constituindo-se a lexia em norma semântico-lexical da localidade. 


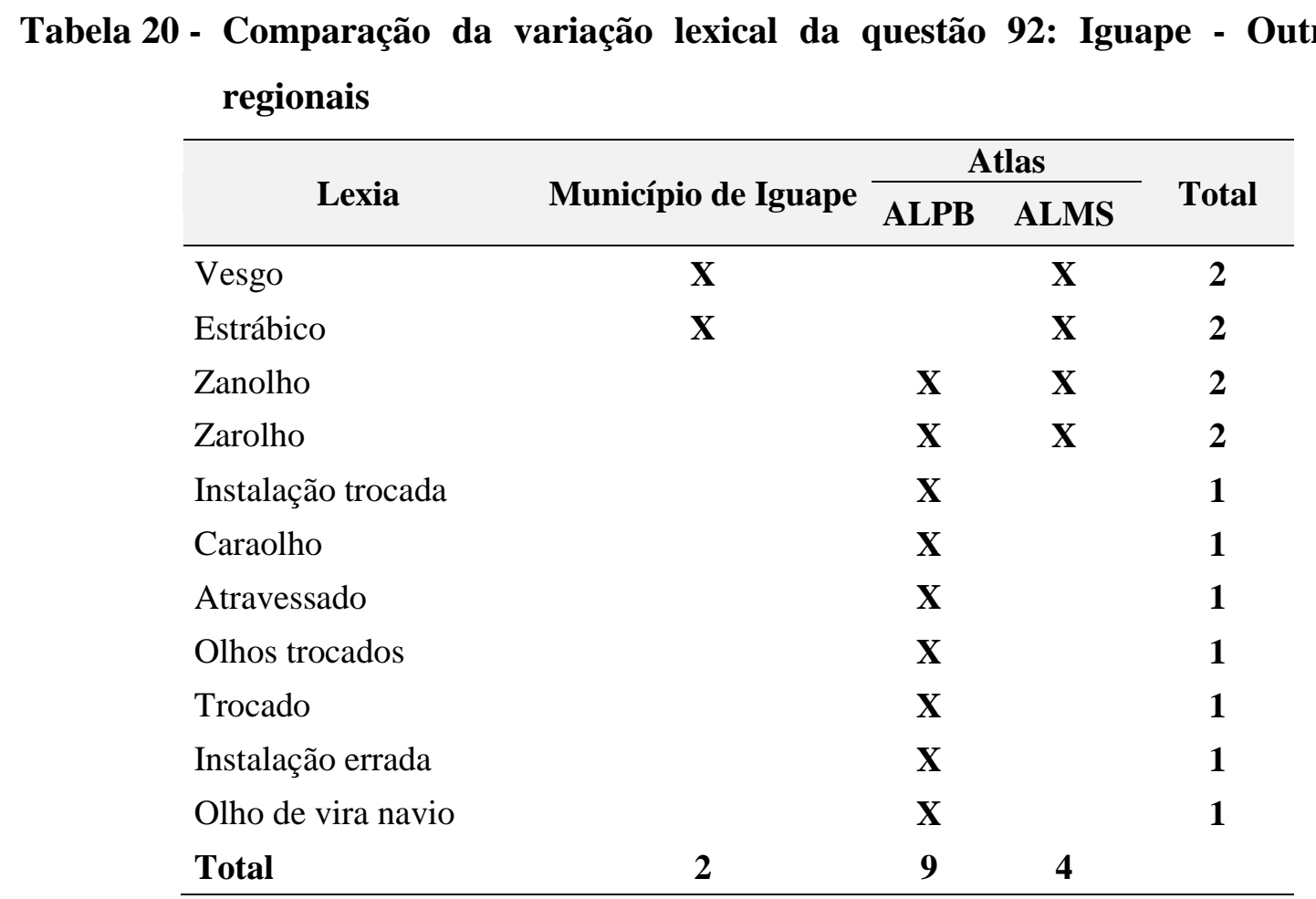

Como podemos observar nesta tabela comparativa, a sugestão/orientação de resposta da questão 92 para o pesquisador, vesgo, é uma das lexias de maior freqüência, ao lado de estrábico, zanolho e zarolho, com ocorrência em Iguape e em dois dos três atlas regionais consultados. Nota-se, também, uma grande variedade de formas, principalmente na Paraíba. O quadro dos dados acima constitui um bom exemplo do caráter da multidialetação no Brasil.

Fica notório, também, pelo léxico relativo ao estrabismo, o preconceito em relação ao portador dessa deficiência visual, e a criatividade das designações: 'olho de vira navio', ‘instalação trocada', 'atravessado', 'olhos trocados', 'trocado' e 'instalação errada'.

\section{Análise de traços semânticos}

Consultando a definição de vesgo nos dicionários gerais de língua portuguesa, e no de medicina de Coutinho (1977), encontramos:

- vesgo/ê/adj. (sXIV cf Fichl VPM) 1 que sofre de desvio de um ou ambos os olhos; que sofre de estrabismo; estrábico, vesgueiro (criança v.) sm. 4. indivíduo vesgo; 
estrábico $\Theta$ ETIM voc. expressivo, cp. esp. bisgo/bizco 'id'; f.hist. s XIV uizcos, s XV uesgo 1569 vesgo ${ }^{\circledR}$ SIN/VAR estrabão; ver tb sinonímia de estrábico (HOUAISS, 2001, p. 2852).

- vesgo (or duv) Adj 1 estrábico. Sm 2 pessoa estrábica. (BORBA, 2004, p.1426)

- vesgo - Estrábico[ver estrabismo] (COUTINHO, p.2414).

- estrábico [de estrab(o)+-ico] Adj 1 Relativo ao, ou próprio do estrabismo. 2 Diz-se de indivíduo atacado de estrabismo. [Sin.: caolho, caraolho, estrabão [este, desus.], mirolho, olhizaino, peto, tortelos, torto, vasqueiro, vesgo, vesgueiro, zãibo ou zãimbo, zambaio, zanaga, zanago, zanolho, zarolho, zerê] (FERREIRA, 2002, p.833).

- estrábico Adj que tem estrabismo; vesgo: um rapaz estrábico, de óculos. (estrabismo) Sm defeito de convergência dos eixos visuais, impossibilitando a fixação de um ponto com os dois olhos (BORBA, p. 560).

- estrabismo [gr. strabismós acção de entortar os olhos] - Estado em que os dois olhos não olham simultaneamente na mesma direcção. Os movimentos dos globos oculares dependem da acção de seis músculos, sendo quatro rectos e dois oblíquos [ver OLHO]. Destes músculos, os rectos externo e interno movem o globo ocular horizontalmente de um lado para o outro e fazem que os dois olhos actuem em conjunto. O músculo recto externo e o músculo recto interno são por isso os mais importantes dos seis, e os defeitos com eles relacionados são o estrabismo para dentro (convergente) ou para fora (divergente) (COUTINHO, p.892).

Vesgo e estrábico são parassinônimos. Como é um termo especializado, estrábico tem traço semântico /+ específico/, enquanto a lexia vesgo apresenta traço /-específico/ ou /+banal/. Portanto, a denominação vesgo é mais popular e seu uso, conseqüentemente, mais freqüente. Não são comutáveis em todos os contextos. 
O semema da lexia vesgo a insere no domínio dos males ou doenças que afetam o olho. Ela se define pela soma de seus predicados, representados pelos semas 'que sofre de desvio', 'que sofre de estrabismo', 'indivíduo atacado de estrabismo', que deixam claro que se trata de um problema de saúde.

O sema inerente 'defeito de convergência' da lexia estrabismo, encontrado em Borba, reporta-se ao indivíduo vesgo, neste caso adjetivo, como portador de uma deficiência. Apesar de não constar dos dicionários, o adjetivo vesgo é hoje em dia evitado, quase interditado, por não ser politicamente correto. A perspicácia do falante/ouvinte interpretou a anomalia e produziu variantes criativas a partir dos semas 'trocada(os)', 'atravessado', 'errada', reportando-se à deficiência de uma forma sutil e brincalhona. São criações como 'olho de vira navio', 'instalação trocada', 'atravessado', 'olhos trocados', 'trocado' e 'instalação errada'.

Já no dicionário de medicina de Coutinho (1977), o termo especializado não apresenta nenhuma conotação depreciativa. Ele é definido neutra e objetivamente por sua etimologia grega 'acção de entortar os olhos', como "estado em que os dois olhos (...)”.

Em Machado (1967, p. 968), a origem etimológica do termo estrábico faz referência a Estrabão, que é o adjetivo e substantivo do grego strabós, pelo latim strobone-, “estrábico; fig., invejoso, ciumento”. Esse semema contém um conjunto de virtualidades que, a qualquer momento, frente ao menor obstáculo que se interponha no processo linear da significação, estão prontas para se atualizar. 'Invejoso', 'ciumento' são semas aferentes de estrábico.

Em algum momento, os olhos foram relacionados à inveja, ao ciúme. Na citação que fazemos a seguir, de Cascudo (1973, p. 240), percebemos por quê:

O pavor, o medo de Fobos _ que era um deus _o receio de todos, é o olhar da deusa Inveja, in-vidia. A que-olha-com-olhos-maus, olha contrariamente para nós, invertendo a felicidade, fortuna, êxito, dissolvendo as alegrias alheias sob o ácido do ciúme e do ódio.

E mais: "A imagem da visão total induzia a uma quase onipotência. O sol é o olho do dia. Olho do tempo, dizia Estrabão ser a História. É a vigilância.” 
Em Diegues (2005, p.247), encontramos a forma virolho, na acepção 'pessoa vesga. Pessoa que enxerga com um olho só. É o mesmo que picega'.

Caolho, caraolho, zarolho, zanolho e bisolho, expressões populares para "vesgo", assentam-se visivelmente em olho, como aponta Guérios (1979, p.145).

Cumpre assinalar que o dicionário registra muitas das formas que aparecem nos atlas lingüísticos pesquisados, e outras até que não aparecem na pesquisa, sem, no entanto, indicar a localidade em que se usa tal variante, sua marca diatópica. Só indica a região.

\subsubsection{Míope}

QUESTÃO nº 93 ... a pessoa que não enxerga longe, e tem que usar óculos?

\section{Freqüência e distribuição}

A tabela a seguir reúne as respostas à questão nº 93, registradas em Iguape.

Tabela 21 - Frequiência geral da questão 93- Iguape

\begin{tabular}{lrr}
\hline \multirow{2}{*}{ Lexia } & \multicolumn{2}{c}{ Freqüência } \\
\cline { 2 - 3 } \multicolumn{1}{c}{ VA } & \multicolumn{1}{c}{ VR (\%) } \\
\hline Míope & 4 & 33,33 \\
Vista curta & 4 & 33,33 \\
Problema de vista & 1 & 8,33 \\
Abstenções & 3 & 25,00 \\
\multicolumn{1}{c}{ TOTAL } & $\mathbf{1 2}$ & $\mathbf{1 0 0 , 0 0}$ \\
\hline
\end{tabular}

Com relação à pergunta “... a pessoa que não enxerga longe, e tem que usar óculos?”, a amostra do falar de Iguape revela uma freqüência dividida igualmente entre duas lexias, míope e vista curta (ou curto da vista), seguida de muitas abstenções e, por último, da realização problema de vista, com pouca incidência. 
Tabela 22 - Frequiência da questão 93 por sexo/gênero

\begin{tabular}{lrrrrrr}
\hline \multirow{2}{*}{ Lexia } & \multicolumn{6}{c}{ Sexo/Gênero } \\
\cline { 2 - 7 } & \multicolumn{2}{c}{ Homens } & \multicolumn{2}{c}{ Mulheres } & \multicolumn{2}{c}{ Total } \\
\cline { 2 - 7 } & VA & \multicolumn{1}{c}{ VR (\%) } & \multicolumn{1}{c}{ VA } & \multicolumn{1}{c}{ VR (\%) } & \multicolumn{1}{c}{ VA } & \multicolumn{1}{c}{ VR (\%) } \\
\hline Míope & 1 & 16,67 & 3 & 50,00 & 4 & 33,33 \\
Vista curta & 2 & 33,33 & 2 & 33,33 & 4 & 33,33 \\
Problema de & & & & & & \\
vista & 1 & 16,67 & 0 & 0,00 & 1 & 8,33 \\
Abstenções & 2 & 33,33 & 1 & 16,67 & 3 & 25,00 \\
$\quad$ Total & $\mathbf{6}$ & $\mathbf{1 0 0 , 0 0}$ & $\mathbf{6}$ & $\mathbf{1 0 0 , 0 0}$ & $\mathbf{1 2}$ & $\mathbf{1 0 0 , 0 0}$ \\
\hline
\end{tabular}

Quanto ao gênero, os números reiteram o que já verificamos anteriormente em Iguape: com relação ao repertório técnico-científico, as mulheres têm maior domínio. Os homens preferem fazer uso de uma variante a atualizar o termo especializado míope. Muitos deles abstiveram-se de responder.

Na tabela abaixo, podemos verificar o uso por faixa etária.

Tabela 23 - Frequiência da questão 93 por faixa etária

\begin{tabular}{lrrrrrr}
\hline \multirow{2}{*}{ Lexia } & \multicolumn{6}{c}{ Faixa Etária } \\
\cline { 2 - 7 } & \multicolumn{2}{c}{$\mathbf{1 8}$ a 30 anos } & \multicolumn{6}{c}{ 66 anos ou mais } & \multicolumn{2}{c}{ Total } \\
\cline { 2 - 7 } & VA & VR (\%) & \multicolumn{1}{c}{ VA } & VR (\%) & \multicolumn{1}{c}{ VA } & \multicolumn{1}{c}{ VR (\%) } \\
\hline Míope & 4 & 66,67 & 0 & 0,00 & 4 & 33,33 \\
Vista curta & 0 & 0,00 & 4 & 66,67 & 4 & 33,33 \\
Problema de & & & & & & \\
vista & 1 & 16,67 & 0 & 0,00 & 1 & 8,33 \\
Abstenções & 1 & 16,67 & 2 & 33,33 & 3 & 25,00 \\
$\quad$ Total & $\mathbf{6}$ & $\mathbf{1 0 0 , 0 0}$ & $\mathbf{6}$ & $\mathbf{1 0 0 , 0 0}$ & $\mathbf{1 2}$ & $\mathbf{1 0 0 , 0 0}$ \\
\hline
\end{tabular}

A preferência de uso do termo técnico-científico pelos sujeitos da primeira faixa etária é patente, ao contrário do que ocorre com os sujeitos da segunda faixa etária. Essa geração, provavelmente, teve mais acesso aos programas de saúde do governo, refletindo-se essa situação no vocabulário, enriquecido desses termos. Também essa geração passou mais anos na escola, o que deve ter ampliado seu vocabulário vernáculo. 
Tabela 24 - Distribuição das lexias da questão 93 pelos pontos

\begin{tabular}{lrrrrrrrr}
\hline \multirow{2}{*}{ Lexia } & \multicolumn{9}{c}{ Ponto } \\
\cline { 2 - 9 } & \multicolumn{2}{c}{ Icapara } & \multicolumn{2}{c}{ Rocio } & \multicolumn{2}{c}{ Jairê } & \multicolumn{2}{c}{ Total } \\
\cline { 2 - 10 } & \multicolumn{1}{c}{ VA } & VR (\%) & \multicolumn{1}{c}{ VA } & \multicolumn{1}{c}{ VR (\%) } & \multicolumn{1}{c}{ VA } & \multicolumn{1}{c}{ VR (\%) } & VA & VR (\%) \\
\hline Míope & 1 & 25,00 & 2 & 50,00 & 1 & 25,00 & 4 & 33,33 \\
Vista curta & 0 & 0,00 & 2 & 50,00 & 2 & 50,00 & 4 & 33,33 \\
Problema de vista & 1 & 25,00 & 0 & 0,00 & 0 & 0,00 & 1 & 8,33 \\
Abstenções & 2 & 50,00 & 0 & 0,00 & 1 & 25,00 & 3 & 25,00 \\
\multicolumn{1}{c}{ Total } & $\mathbf{4}$ & $\mathbf{1 0 0 , 0 0}$ & $\mathbf{4}$ & $\mathbf{1 0 0 , 0 0}$ & $\mathbf{4}$ & $\mathbf{1 0 0 , 0 0}$ & $\mathbf{1 2}$ & $\mathbf{1 0 0 , 0 0}$ \\
\hline
\end{tabular}

A distribuição do termo míope e da lexia complexa vista curta está mais concentrada no Rocio.

\section{Análise de traços semânticos}

A pergunta do QSL está bem formulada, contemplando os semas que figuram nas definições dos dicionários, e favorecendo a interpretação/produção da resposta do sujeito pesquisado. Míope e miopia são termos da linguagem de especialidade médica e, por isso, além dos dicionários gerais de língua portuguesa, consultamos o de medicina, de Coutinho (1977), para analisarmos a combinação de seus semas:

- míope 1 afetado por miopia, 2 que ou aquele que sofre de miopia (indivíduo ou pessoa m.) (o m. vê mal o que está longe) e a etimologia gr. myóps,opos 'que pisca os olhos para ver melhor', pelo lat. tar. myopis,opis 'que tem a vista curta, que pisca os olhos', com recuo da tônica; (...) (HOUAISS, 2001, p.1929).

- miopia [de míope+-ia] s.f. 1 Oftalm.Vício de refração em que os raios luminosos que entram em cada olho, paralelamente ao eixo óptico, são levados a um foco aquém da retina, dado o alongamento ântero-posterior que existe nesse olho. (Sin., pop.: vista curta, cf. hipermetropia) (FERREIRA, 2002, p.1336).

- miopia [gr. myopia vista curta] (Sin.: vista curta) - Anomalia da refracção que consiste na convergência dos raios luminosos provenientes dos objetos colocados a certa distância, num ponto situado à frente da retina. A sua correcção faz-se com lentes divergentes (côncavas) (COUTINHO, p. 1504-1505). 
A lexia complexa vista curta, registrada como resposta à questão 93, é bem mais popular que míope e, no entanto, tem origem tão erudita quanto ela. Como vemos nos três dicionários pesquisados, o núcleo sêmico da lexia míope, é o sema inerente 'vista curta'. Ele sofre um processo de atualização seletiva e, de núcleo sêmico da lexia, passa a explorar as possibilidades semântico-lexicais do sistema, e disjungindo da lexia-mãe, torna-se um lexema autônomo para, em seguida, ser atualizado no discurso como a lexia complexa vista curta. Trata-se de um processo por aferência que, segundo definição de Borba (2004, p.30) para esse termo, quer dizer "condução ou transporte de um ponto qualquer para um centro".

A sabedoria popular, em mais este caso, optou pela designação do referente pela sua descrição e encontrou a mesma fórmula da origem etimológica grega: vista curta/curto da vista é a forma mais transparente e mais direta. Isso nos levou a pensar na possibilidade de existirem, realmente, universais semânticos. Segundo Martin (apud RASTIER, 1987, p. 26): “certos dados do mundo, físicos, fisiológicos, antropoculturais, exercem sobre a vida dos homens uma tão forte influência que é impossível que eles não deixem alguma marca na língua. E esses traços, de fato, têm toda chance de ser universais." Completa Hagège (apud RASTIER, 1987, p. 27) que todas as línguas podem, não sem dificuldade, se traduzir e que "a tradução é a única garantia que nós temos de uma substância semântica ao menos em parte comum a todas as línguas.”

A lexia estudada, míope, assim como as lexias cego de um olho (questão 91) e vesgo (questão 92), designam deficiências ou anomalias, neste caso do domínio da oftalmologia, passíveis, portanto, de tratamento e, por outro lado, de preconceito. Os semas 'afetado por miopia', 'que ou aquele que sofre de miopia' e 'anomalia da refracção' se reportam à patologia da doença. Neste caso, o tratamento faz parte dos semas inerentes: "sua correcção faz-se com lentes divergentes (côncavas)". 
Já o preconceito não tem cura. Apesar de não constar dos dicionários, existe um preconceito velado com relação às pessoas que usam óculos, que desde crianças são chamadas de "quatro olhos". Guérios (1979, p. 146) acredita ser caso de tabuísmo o uso no diminutivo de nomes de deficiências físicas como cegueta, para “míope’, “pisca-pisca”, que encontramos no sema inerente 'que pisca os olhos'.

À parte a conotação disfórica dos olhos míopes, os olhos são tema de muita reverência e curiosidade: Cascudo (1973), em dois momentos, destaca alguns desses aspectos:

“(...) Olho significa onde a vida principia, o começo, olho-da-planta, o rebento, o botão, olho-d'água, a nascente, a fonte.(...)” (p.240-241).

"Para que os olhos reunissem tanto crédito a explicação seria de que eles impressionaram pelo brilho inusitado, pela fixidez enérgica, pelo poder magnético inconsciente. O olhar de chefe, olhar de comando, deve ser tão antigo quanto a própria chefia. De todos os órgãos é o único a agir sem contato imediato, determinando o estranho ambiente sugestionante, espécie de halo ao perfil voluntarioso do dominador. Como outrora e hoje ninguém sabe explicar o poder dos olhos pela simples mecânica muscular, e a "eloqüência" ou intenção têm poderes reais que a física não compreende quando expressos num olhar rápido, decisivo, fulminante, ao primitivo pareceria presença mágica a cintilância e penetração de certos olhos privilegiados." (id., ibidem) 


\subsubsection{Terçol}

QUESTÃO 94 -. a bolinha que nasce na (cf. item 89), fica vermelha e incha?

\section{Freqüiência e distribuição}

A tabela a seguir reúne as respostas à questão ${ }^{\circ} 94$ :

Tabela 25 - Freqüiência geral da questão 94- Iguape

\begin{tabular}{lrr}
\hline \multirow{2}{*}{ Lexia } & \multicolumn{2}{c}{ Freqüiência } \\
\cline { 2 - 3 } & \multicolumn{1}{c}{ VA } & \multicolumn{1}{c}{ VR $(\boldsymbol{\%})$} \\
\hline Viúva & 10 & 83,33 \\
Terçol & 1 & 8,33 \\
Abstenções & 1 & 8,33 \\
$\quad$ Total & $\mathbf{1 2}$ & $\mathbf{1 0 0 , 0 0}$ \\
\hline
\end{tabular}

Do total de sujeitos ouvidos em Iguape, a expressiva maioria emprega a lexia viúva para se referir à 'bolinha que nasce na pálpebra, fica vermelha e incha'. Trata-se de uma norma semântico-lexical da localidade. E uma minoria emprega a lexia terçol.

A resposta a essa pergunta foi quase categórica, revelando ser Também se observa alta freqüência da lexia, tanto absoluta quanto relativa, para os sujeitos entrevistados de ambos os sexos/gêneros. O uso da lexia viúva é norma entre os iguapenses, não se limitando a um dos sexos/gêneros. Vejamos os números:

Tabela 26 - Freqüência da questão 94 por sexo/gênero

\begin{tabular}{lrrrrrr}
\hline \multirow{2}{*}{ Lexia } & \multicolumn{6}{c}{ Sexo/Gênero } \\
\cline { 2 - 7 } & \multicolumn{2}{c}{ Homens } & \multicolumn{2}{c}{ Mulheres } & \multicolumn{2}{c}{ Total } \\
& VA & VR (\%) & \multicolumn{1}{c}{ VA } & VR (\%) & \multicolumn{1}{c}{ VA } & \multicolumn{1}{c}{ VR (\%) } \\
\hline Viúva & 5 & 83,33 & 5 & 83,33 & 10 & 83,33 \\
Terçol & 1 & 16,67 & 0 & 0,00 & 1 & 8,33 \\
Abstenções & 0 & 0,00 & 1 & 16,67 & 1 & 8,33 \\
$\quad$ Total & $\mathbf{6}$ & $\mathbf{1 0 0 , 0 0}$ & $\mathbf{6}$ & $\mathbf{1 0 0 , 0 0}$ & $\mathbf{1 2}$ & $\mathbf{1 0 0 , 0 0}$ \\
\hline
\end{tabular}

Na tabela abaixo, podemos verificar o uso por faixa etária. 


\section{Tabela 27 - Freqüiência da questão 94 por faixa etária}

\begin{tabular}{lrrrrrr}
\hline \multirow{2}{*}{ Lexia } & \multicolumn{6}{c}{ Faixa Etária } \\
\cline { 2 - 7 } & \multicolumn{2}{c}{$\mathbf{1 8}$ a 30 anos } & \multicolumn{2}{c}{ 66 anos ou mais } & \multicolumn{2}{c}{ Total } \\
\cline { 2 - 7 } & VA & \multicolumn{1}{c}{ VR (\%) } & \multicolumn{1}{c}{ VA } & VR (\%) & \multicolumn{1}{c}{ VA } & \multicolumn{1}{c}{ VR (\%) } \\
\hline Viúva & 6 & 100,00 & 4 & 66,67 & 10 & 83,33 \\
Terçol & 0 & 0,00 & 1 & 16,67 & 1 & 8,33 \\
Abstenções & 0 & 0,00 & 1 & 16,67 & 1 & 8,33 \\
Total & $\mathbf{6}$ & $\mathbf{1 0 0 , 0 0}$ & $\mathbf{6}$ & $\mathbf{1 0 0 , 0 0}$ & $\mathbf{1 2}$ & $\mathbf{1 0 0 , 0 0}$ \\
\hline
\end{tabular}

Para nossa surpresa, a única ocorrência da lexia terçol aparece na segunda faixa etária: foi empregada por um único sujeito de idade mais avançada, que supúnhamos desse preferência a uma lexia normalizada na comunidade, como é o caso de viúva. Por outro lado, a primeira faixa etária apresentou $100 \%$ de uso da lexia viúva, ignorando o termo da área médica terçol.

Vejamos agora como se distribui a lexia estudada nos pontos selecionados.

Tabela 28 - Distribuição das lexias da questão 94 pelos pontos

\begin{tabular}{lrrrrrrrr}
\hline \multirow{2}{*}{ Lexia } & \multicolumn{1}{c}{ Icapara } & \multicolumn{2}{c}{ Rocio } & \multicolumn{2}{c}{ Jairê } & \multicolumn{2}{c}{ Total } \\
\cline { 2 - 10 } & VA & \multicolumn{1}{c}{ VR (\%) } & \multicolumn{1}{c}{ VA } & \multicolumn{1}{c}{ VR (\%) } & \multicolumn{1}{c}{ VA } & \multicolumn{1}{c}{ VR (\%) } & \multicolumn{1}{c}{ VA } & \multicolumn{1}{c}{ VR (\%) } \\
\hline Viúva & 3 & 75,00 & 3 & 75,00 & 4 & 100,00 & 10 & 83,33 \\
Terçol & 0 & 0,00 & 1 & 25,00 & 0 & 0,00 & 1 & 8,33 \\
Abstenções & 1 & 25,00 & 0 & 0,00 & 0 & 0,00 & 1 & 8,33 \\
$\quad$ Total & $\mathbf{4}$ & $\mathbf{1 0 0 , 0 0}$ & $\mathbf{4}$ & $\mathbf{1 0 0 , 0 0}$ & $\mathbf{4}$ & $\mathbf{1 0 0 , 0 0}$ & $\mathbf{1 2}$ & $\mathbf{1 0 0 , 0 0}$ \\
\hline
\end{tabular}

Como era de se esperar, o bairro mais isolado, e por isso mesmo menos exposto a influências resultantes do contato com o centro urbano de Iguape, o Jairê, apresenta $100 \%$ de atualização da variante viúva, levando-nos a crer que o uso desta lexia seja mais antigo e que ela seja mais motivada semanticamente para o falante local do que terçol. A lexia viúva também é norma semântico-lexical de Iguape. 


Tabela 29 - Comparação da variação lexical da questão 94: Iguape - O
\begin{tabular}{llccc} 
regionais & & & \\
\hline Lexia & Município de Iguape & Atlas ALPB & Total \\
\hline Terçol & $\mathbf{X}$ & $\mathbf{X}$ & $\mathbf{2}$ \\
Viúva & $\mathbf{X}$ & & 1 \\
$\quad$ TOTAL & $\mathbf{2}$ & $\mathbf{1}$ & \\
\hline
\end{tabular}

Não registramos a ocorrência da variante viúva no atlas que consultamos.

\section{Análise de traços semânticos}

Vamos, então, aos dicionários para procurar a relação entre as duas formas, os semas inerentes em comum e, se houver, o núcleo sêmico ou os semas aferentes que justifiquem o uso lingüístico local viúva. Pesquisamos em dicionários gerais de língua portuguesa e nos dicionários de medicina de Coutinho (1977) e Braier (1964), e no dicionário de Cascudo (1979).

Apesar de ser mais usual a forma lematizada da lexia no masculino, encontramos primeiro a entrada viúva e, três entradas depois, viúvo. Seguem-se as definições:

- viúva. Do lat. vidua, com deslocamento do acento para o $u$ e desdobramento do $u$ em hiato, dando uma forma *viduva (cf. caule-couve, loar-louvar, audire-ouvir). Há duas plantas com esse nome: falta a relação. Há um pássaro africano de plumagem escura (Fulica atra). Há pássaros da família Tyrannidae, como o Copurus colonus, de cor preta com algum ornato branco bem destacado. O macho da espécie Lichenops perspicillata, da mesma família, é inteiramente preto, com espelho branco no meio das asas. Há um peixe dos Açores,; falta a relação (NASCENTES, 1966, p. 779).

- viúva 1 mulher cujo marido morreu, e ainda não casou de novo, 'que perdeu o marido; separada do marido; solteira.' Em viúvo, o mesmo autor apresenta, na $2^{\mathrm{a}}$. acepção, o sentido figurado 'que está ou se sente em desamparo, desconsolo, privação, solidão’ (HOUAISS, 2001, p. 2874). 
- viuvez 1. estado de quem é viúvo; e 2. Fig. Desconsolo por desamparo; solidão, privação (FERREIRA, 2002, p. 2081).

Por fim, em Cascudo (1979), selecionamos as seguintes passagens da definição do verbete viúva.

Era entidade de alto respeito, (...). Representava a idéia viva da morte e quase um sobrevivente. A mulher viúva usava vestes pretas, o resto de sua existência. (...) Liga-se à viúva a imagem da mulher desprotegida e fraca, à mercê de qualquer violência e sem possibilidade de defesa. (...) $\mathrm{O}$ voto instintivo e popular é para a viúva, e não o viúvo, conservar-se no seu estado de eterna esposa, como defendem os positivistas" (p.794-795).

Vamos considerar a lexia viúva, na acepção "mulher cujo marido morreu" como viúva ${ }^{l}$. A forma homônima, registrada em Iguape como parassinônimo de terçol, será viúva ${ }^{2}$. Somente a lexia viúva ${ }^{1}$ consta dos dicionários consultados. Vamos tentar, para justificar a associação entre as duas lexias, estabelecer uma relação. Entre os semas de viúva e de terçol, deve ter se dado uma inferência, remetendo a normas socializadas na região, produzindo a variante lexical viúva ${ }^{2}$.

Os semas inerentes de viúva ${ }^{1}$, recorrentes, relativos à solidão, 'que perdeu o marido', 'solteira', 'separada do marido', identificaram-se com o núcleo sêmico de terçol, aproximadamente 'uma bolinha solitária no olho' e tornaram-se produtivos a ponto de criar a variante lexical em estudo viúva ${ }^{2}$, não lexicalizada nos dicionários, mas encontrada em nossa pesquisa em Iguape. Os semas aferentes que subjazem ao processo da significação podem ter sido evocados por inferência, ou por analogia, e ter sido atualizados no discurso por meio dessa variante lexical. Parece ter sido esse o caso da lexia viúva.

Encontramos apenas em Diegues (2005, p. 247) a lexia viúva registrada como "o mesmo que terçol. Inflamação dos olhos; conjuntivite.”

A outra resposta registrada quanto à questão 94, terçol, é um termo da linguagem de especialidade médica. Fomos pesquisar sua origem e rede semêmica: 
- terçol, terçolho, treçolho ou terçogo [lat. triticeolus] (sin. hordéolo) inflamação das glândulas sebáceas da pálpebra; espécie de furúnculo do olho (COUTINHO, p. 2199).

- terçol, sm. (1721cf.RB) OFT infrm m.q. hordéolo \& ETIM orig. contrv., e a explicação etimológica: "Corominas deriva do lat. hordeolus, $i$, diminutivo de hordeum, $i$ 'cevada', através de um arcaísmo orçoo que uma etimologia popular interpretara como 'torce olho'; explicar-se-iam por processo semelhante as formas 'terçó, treçó, treçol ou terçogo, terçolho, torçol, torçolho'. (...) Carolina de Michaëlis aponta o lat. triticeolum,, derivado de triticelus, a,um 'relativo ao trigo', este de triticum, $i$ 'trigo'; essa hipótese explicaria o significado, dada a possibilidade de comparação entre o terçol e um grãozinho de trigo, mas, quanto à forma, cai-se no mesmo impasse já visto para *tertiolus (HOUAISS, 2001, p. 2700).

- terçol o lat. tinha hordeolu "grãozinho de cevada", que é o étimo do esp. orzuelo, do it. orzaiulo e do fr. orgelet. Mas, para hordeolu ser o étimo do port. há duas dificuldades: o $t$ inicial, e o final -olu não dando ó (NASCENTES, 1966, p.725).

Voltamos para um dicionário de Medicina, em espanhol, e encontramos na entrada orzuelo:

- (del lat. ordeolus, pequeño grano de cebada) m. inflamación aguda purulenta circunscrita del borde del párpado (...), especialmente en niños y adultos jóvenes. Se caracteriza por tumefacción roja en el borde palpebral, edema considerable, dolor y aparición de um punto amarillento em el sitio de la supuración. Presenta notable tendencia a la recidiva y a la complicación com blefaritis” (BRAIER, 1964, p. 943).

Nos dicionários de língua geral, consultando Aulete (1958, p. 4922), sob a rubrica med., lemos: "pequeno tumor inflamatório que nasce no bordo das pálpebras." Em Ferreira (2002, p.1947), rubrica oftalm.: "pequeno abscesso na borda das pálpebras; hordéolo.” 
Ao examinar melhor os sememas de terçol, vemos que não há traços em comum conjugando essa lexia e viúva ${ }^{l}$. Pelo menos em termos dos semas inerentes. Destaquemos dentre os sememas de viúval, o sema inerente 'solteira'; e dentre os semas de terçol, o traço distintivo inerente 'dolor'. Ao que parece, operou-se uma atualização seletiva de traços, potencializando o traço aferente da fragilidade do sexo feminino, inferido pela recorrência dos adjetivos 'desprotegida', 'fraca', sobressaindo o sema aferente 'solitária', conotado por "solteira", subjacente à viuvez, e relacionando-o, em terçol, a um 'pequeno grão de trigo ou cevada', 'uma bolinha solitária’ na pálpebra.

Outros semas, virtuais, podem fazer outros percursos possíveis. Dentre vários fatores que podem condicionar essa variação, está a cultura de um povo, suas crenças, valores e visão de mundo, que a norma semântico-lexical compartilhada pela comunidade reflete.

Além do sema aferente 'solitária', que motiva sobremaneira a produção da variante lexical viúva, um dos semas inerentes de terçol, 'dolor', está presente implicitamente nos semas da lexia viúva ${ }^{l}$, é sema aferente, conotando perda, privação. Acreditamos que assim se justifique a associação entre as lexias viúva ${ }^{l}$ e terçol: elas têm em comum os semas aferentes 'solitária' e 'dolor'.

Tanto é verdade que o traço mais marcante de viúva é a solidão, que o vulgo instintivamente deseja que a viúva mantenha seu estado de solidão e de dor, e reprova um novo casamento, ficando-lhe o papel de eterna esposa, como anotou Cascudo em sua última citação. No entanto, a 'mulher cujo marido morreu, e ainda não casou de novo' faz crer que não ficará por muito tempo solitária, casando com outro homem. E com outro, se tornar a enviuvar. O que lembra o sema inerente da lexia terçol 'presenta notable tendência a la recidiva'. E também a estória típica que corre no Brasil, recolhida por Cascudo (1979): 
Um amigo de Jesus Cristo convidou-o para suas bodas. Nosso Senhor compareceu e abençoou o casal. Tempos depois, o homem enviuvou e deliberou casar-se novamente. Foi convidar Nosso Senhor, que lhe disse: "Não vou, mas mando" (um representante). E mandou. O homem enviuvou pela segunda vez, contratou núpcias e voltou à presença de Jesus Cristo para o convite. Nosso Senhor declarou: "Nem vou, nem mando". Era a reprovação total (p. 794).

Às doenças também se dão nomes de parentela, com o que se evitam os verdadeiros nomes. Trata-se, segundo Guérios (1979, p.14), de um tipo de tabu lingüístico substituído por uma expressão de carinho ou louvor, um hipocorístico. Com isto, pretende-se transformar o inimigo em amigo, ou neutralizar-lhe as forças malignas. Guérios (1979, p.140) comenta que, no francês, o terçol é denominado compère-loriot, isto é, "compadre terçol".

\subsubsection{Conjuntivite}

Questão 95 - ... a inflamação no olho que faz com que o olho fique vermelho e amanheça grudado?

A tabela a seguir reúne as respostas à questão nº 95 :

\section{Tabela 30 - Frequiência geral da questão 95- Iguape}

\begin{tabular}{lrr}
\hline \multirow{2}{*}{ Lexia } & \multicolumn{2}{c}{ Freqüência } \\
\cline { 2 - 3 } & \multicolumn{1}{c}{ VA } & \multicolumn{1}{c}{ VR (\%) } \\
\hline Conjuntivite & 5 & 41,67 \\
Dordolhos & 3 & 25,00 \\
Abstenções & 4 & 33,33 \\
Total & $\mathbf{1 2}$ & $\mathbf{1 0 0 , 0 0}$ \\
\hline
\end{tabular}

$\mathrm{O}$ uso da lexia conjuntivite, em Iguape, para referir a inflamação que dá no olho e incomoda bastante, representa quase 50\% das respostas colhidas. Dordolhos ainda é empregada, mas até mesmo em comparação às abstenções, tem menor freqüência.

Os sujeitos de ambos os gêneros usam indistintamente a lexia conjuntivite, como podemos observar na tabela abaixo: 
Tabela 31 - Frequiência da questão 95 por sexo/gênero

\begin{tabular}{lrrrrrr}
\hline \multirow{2}{*}{ Lexia } & \multicolumn{6}{c}{ Sexo/Gênero } \\
\cline { 2 - 7 } & \multicolumn{2}{c}{ Homens } & \multicolumn{2}{c}{ Mulheres } & \multicolumn{2}{c}{ Total } \\
& VA & \multicolumn{1}{c}{ VR (\%) } & \multicolumn{1}{c}{ VA } & VR (\%) & \multicolumn{1}{c}{ VA } & \multicolumn{1}{c}{ VR (\%) } \\
\hline Conjuntivite & 2 & 33,33 & 3 & 50,00 & 5 & 41,67 \\
Dordolhos & 3 & 50,00 & 0 & 0,00 & 3 & 25,00 \\
Abstenções & 1 & 16,67 & 3 & 50,00 & 4 & 33,33 \\
$\quad$ Total & $\mathbf{6}$ & $\mathbf{1 0 0 , 0 0}$ & $\mathbf{6}$ & $\mathbf{1 0 0 , 0 0}$ & $\mathbf{1 2}$ & $\mathbf{1 0 0 , 0 0}$ \\
\hline
\end{tabular}

É interessante notar que são os homens que conservam mais a lexia dordolhos, usadas em situações 'não-marcadas'. As mulheres, reiteradamente, dominam melhor o léxico de termos especializados, preferindo abster-se a atualizar a variante dordolhos.

Na tabela abaixo, podemos verificar o uso por faixa etária.

Tabela 32 - Freqüiência da questão 95 por faixa etária

\begin{tabular}{lrrrrrr}
\hline \multirow{2}{*}{ Lexia } & \multicolumn{6}{c}{ Faixa Etária } \\
\cline { 2 - 7 } & \multicolumn{2}{c}{$\mathbf{1 8}$ a 30 anos } & \multicolumn{2}{c}{ 66 anos ou mais } & \multicolumn{2}{c}{ Total } \\
\cline { 2 - 7 } & VA & VR (\%) & \multicolumn{1}{c}{ VA } & VR (\%) & \multicolumn{1}{c}{ VA } & \multicolumn{1}{c}{ VR (\%) } \\
\hline Conjuntivite & 5 & 83,33 & 0 & 0,00 & 5 & 41,67 \\
Dordolhos & 0 & 0,00 & 3 & 50,00 & 3 & 25,00 \\
Abstenções & 1 & 16,67 & 3 & 50,00 & 4 & 33,33 \\
$\quad$ Total & $\mathbf{6}$ & $\mathbf{1 0 0 , 0 0}$ & $\mathbf{6}$ & $\mathbf{1 0 0 , 0 0}$ & $\mathbf{1 2}$ & $\mathbf{1 0 0 , 0 0}$ \\
\hline
\end{tabular}

A lexia conjuntivite foi selecionada pela maioria dos sujeitos da primeira faixa etária, revelando-se bastante produtiva entre os mais jovens, e pelo contrário, de realização nula entre os mais velhos. Provavelmente o uso dessa lexia é novo na comunidade, daí conviver em paralelo com a variante mais antiga, usada pelos mais velhos, dordolhos, sem ocorrer comutação das formas entre as gerações. Observe-se que nenhum dos sujeitos da primeira faixa etária atualizou a forma dordolhos, enquanto, na segunda faixa, nenhum sujeito empregou conjuntivite.

Vejamos agora como se distribui a lexia estudada nos pontos selecionados. 
Tabela 33 - Distribuição das lexias da questão 95 pelos pontos

\begin{tabular}{lrrrrrrrr}
\hline \multirow{2}{*}{ Lexia } & \multicolumn{8}{c}{ Ponto } \\
\cline { 2 - 9 } & \multicolumn{2}{c}{ Icapara } & \multicolumn{2}{c}{ Rocio } & \multicolumn{2}{c}{ Jairê } & \multicolumn{2}{c}{ Total } \\
\cline { 2 - 9 } & \multicolumn{1}{c}{ VA } & \multicolumn{1}{c}{ VR (\%) } & \multicolumn{1}{c}{ VA } & \multicolumn{1}{c}{ VR (\%) } & \multicolumn{1}{c}{ VA } & \multicolumn{1}{c}{ VR (\%) } & \multicolumn{1}{c}{ VA } & \multicolumn{1}{c}{ VR (\%) } \\
\hline Conjuntivite & 2 & 50,00 & 2 & 50,00 & 1 & 25,00 & 5 & 41,67 \\
Dordolhos & 1 & 25,00 & 1 & 25,00 & 1 & 25,00 & 3 & 25,00 \\
Abstenções & 1 & 25,00 & 1 & 25,00 & 2 & 50,00 & 4 & 33,33 \\
TOTAL & $\mathbf{4}$ & $\mathbf{1 0 0 , 0 0}$ & $\mathbf{4}$ & $\mathbf{1 0 0 , 0 0}$ & $\mathbf{4}$ & $\mathbf{1 0 0 , 0 0}$ & $\mathbf{1 2}$ & $\mathbf{1 0 0 , 0 0}$ \\
\hline
\end{tabular}

Em dois bairros, Icapara e Rocio, emprega-se majoritariamente a forma conjuntivite, enquanto no Jairê a relação se inverte: metade dos sujeitos não sabe como se designa essa doença dos olhos, e a outra metade está dividida entre as denominações conjuntivite e dordolhos.

Tabela 34 - Comparação da variação lexical da questão 95: Iguape - Outros atlas regionais

\begin{tabular}{|c|c|c|c|c|}
\hline \multirow[b]{2}{*}{ Lexia } & \multirow[b]{2}{*}{ Município de Iguape } & \multicolumn{2}{|c|}{ Atlas } & \multirow[b]{2}{*}{ Total } \\
\hline & & APFB & ALPB & \\
\hline Dordolhos & $\mathbf{X}$ & $\mathbf{X}$ & $\mathbf{X}$ & 3 \\
\hline Sapiranga & & $\mathbf{X}$ & $\mathbf{X}$ & 2 \\
\hline Conjuntivite & $\mathbf{X}$ & & & 1 \\
\hline Doença de olhos & & & $\mathbf{X}$ & 1 \\
\hline Constipação & & & $\mathbf{X}$ & 1 \\
\hline $\begin{array}{l}\text { Carregação nos } \\
\text { olhos }\end{array}$ & & & $\mathbf{X}$ & 1 \\
\hline Remelência & & & $\mathbf{X}$ & 1 \\
\hline Total & 2 & 2 & 6 & \\
\hline
\end{tabular}

Como podemos notar, a sugestão/orientação de provável resposta para o pesquisador, conjuntivite, não está presente no APFB nem no ALPB. A única lexia que aparece nos três atlas é dordolhos. Segue-se outra variante com ocorrência em dois dos atlas, sapiranga e, com apenas uma ocorrência, temos conjuntivite, em Iguape. Estes e outros dados quantitativos que seguem subsidiarão a análise de traços semânticos da lexia conjuntivite e suas variantes em Iguape. 


\section{Análise de traços semânticos}

De novo temos um termo da área médica, referente ainda à região dos olhos. Vamos apresentar a seguir as definições de conjuntivite que encontramos nos dicionários gerais de língua portuguesa e de medicina de Coutinho (1977):

- conjuntivite [conjuntiva+-ite] Processo inflamatório da conjuntiva. Ver OLHO (DOENÇAS DO) (COUTINHO, p. 562).

- OLHO (DOENÇAS DO) Nas inflamações da conjuntiva, e, especialmente na conjuntivite aguda, há uma supuração abundante, e por isso deve evitar-se a oclusão do olho, que reteria o pus. Aplicar um antibiótico em pomada ou colírio. Evitar a cortisona (...) (COUTINHO, p. 1636).

- conjuntivite [De conjuntiva+-ite ${ }^{1}$ S Substantivo feminino. 1. Patol. Inflamação da conjuntiva. [Sin. bras., pop.: carregação dos olhos.] (FERREIRA, dic. eletr.).

- conjuntiva [Do lat. cient. conjunctiva]. Substantivo feminino. 01. Anat. Membrana que reveste internamente as pálpebras (conjuntiva palpebral), e a porção exposta da esclerótica (conjuntiva ocular); adnata. 2.Lóg. Cada uma das proposições [v. proposição (6)] numa relação de conjunção (7) (FERREIRA, dic. eletr.).

- conjuntivite OFT inflamação da conjuntiva, ger. com hiperemia nessa mucosa e a produção de secreções. ETIM conjuntiva+ite, prov. sob infl. do fr. conjonctivite (1832) 'id'; ver jug-; f.hist. 1873 conjunctivite (HOUAISS, 2001, p.804).

- (conjuntiva) sf membrana transparente que cobre a parte branca dos olhos e a parte interna das pálpebras (BORBA, 2004, p. 326).

Temos praticamente um único semema do verbete conjuntivite. Exceto pela inclusão que Ferreira (dic. eletr.) faz de uma acepção da Lógica, ele se inclui no domínio da “oftalmologia” ou “doenças do olho". 
Os semas inerentes 'inflamação', 'processo inflamatório', 'supuração', 'pus', 'secreções' justificam e motivam semanticamente a produção das variantes constipação e remelência, que são registradas pelo ALPB, assim como, também, doença de olhos e carregação nos olhos, que aparece em Ferreira (dic. eletr.) com a marca [Sin. bras., pop.:].

Encontramos muitas variantes relativas à anatomia do olho, como vimos em pálpebra, assim como para as doenças dos olhos, como em vesgo, caolho, míope, terçol e conjuntivite, e vamos ver em catarata; ou simplesmente relacionadas ao olho, como cisco.

Essas questões do QSL, oito no total, pertencem à classe semântica olho. Sobre os olhos, encontramos em Cascudo (1973):

Há peças decoradas inteiramente pelos olhos. Outras em que o friso é constituído por uma fieira simples ou dupla de olhos. São os vasos chamados Occhiale. Há ornamentação de olhos na cerâmica dos maias na América Central. Vem de Tróia à Escandinávia, pelo Mediterrâneo, Atlântico, Mar do Norte, Báltico. É presente pela África, Oceania, nas ilhas distantes do sul, entre indígenas sul-americanos, numa espantosa difusão apotropaica (p.240).

Voltando a pesquisar sobre a importância dos olhos, constatamos que desde há muito que a humanidade reconhece seu poder e fascínio:

Na cerâmica grega, desde o século VI a.C., em vasos da Ática, Corinto, Mileto, Rodes, pela Ásia Menor, pela Etrúria, aparece comumente a cabeça da Medusa que, petrificando quem a olhasse, tornou-se amuleto para deter a má sorte, as forças malfazejas, tudo quanto um olhar pode irradiar no sentido da potência adversa. A cabeça da Medusa que o herói Perseu decepara denominava-se "gorgoneion", e é encontrada nos vasos, na ombreira das portas, nos escudos, no punho dos gládios, nas túnicas, na proa dos barcos, na louça de uso diário, especialmente no vasilhame de beber, nas jóias, nos móveis, cadeiras, bisélios, leitos, nas colunas de mármore, na roda dos carros sagrados, nas liteiras, nos anfiteatros, aquedutos, marcos miliários. Nem sempre se depara o "gorgoneion" mas simplesmente os dois olhos ou em número bem maior (CASCUDO, 1973, p.239).

Como vimos, a simples inscrição de um desenho da cabeça da Medusa ou de seus

olhos bastava para afastar as forças do mal. E mais:

A finalidade é a mesma: defender, afastar, evitar a influência maléfica do mauolhado, fascínio, olho-grande, olhão, mauvais oeil, malocchio, Evil eye, Böse blick, Jettatura, mal de ojo, daño de aojamiento.

Por isso, gregos e romanos gravavam, pintavam, esculpiam olhos nos túmulos para que os mortos repousassem em paz e livres do que o mau-olhar pode fazer. (...) Os deuses precisavam defender-se do olho-mau, tão poderoso quanto eles (CASCUDO, 1973, p.239-240). 
A presença de tantas variantes relacionadas a olhos e doenças dos olhos só pode refletir a importância que se dava/dá em todas as civilizações e culturas a essa parte do corpo humano, associado sempre a poder:

\begin{abstract}
Para que os olhos reunissem tanto crédito a explicação seria de que eles impressionaram pelo brilho inusitado, pela fixidez enérgica, pelo poder magnético inconsciente. (...) De todos os órgãos é o único a agir sem contato imediato, determinando o estranho ambiente sugestionante, espécie de halo ao perfil voluntarioso do dominador. (...) Fitar de frente os olhos tornou-se uso restrito na ambivalência amor e medo, amor pela atração da obediência e medo à contaminação maléfica (CASCUDO, 1973, p. 240).
\end{abstract}

\title{
5.1.8 Catarata
}

QUESTÃO 96 -... aquela pele branca no olho que dá em pessoas mais idosas?

\section{Freqüiência e distribuição}

A tabela a seguir reúne as respostas à questão $n^{\circ} 96$ :

\section{Tabela 35 - Freqüência geral da questão 96- Iguape}

\begin{tabular}{lrr}
\hline \multirow{2}{*}{ Lexia } & \multicolumn{2}{c}{ Freqüência } \\
\cline { 2 - 3 } & \multicolumn{1}{c}{ VA } & \multicolumn{1}{c}{ VR (\%) } \\
\hline Catarata & 5 & 41,67 \\
Abstenções & 7 & 58,33 \\
Total & $\mathbf{1 2}$ & $\mathbf{1 0 0 , 0 0}$ \\
\hline
\end{tabular}

A lexia catarata é pouco utilizada, em Iguape. Menos da metade dos sujeitos ouvidos conhece a denominação dessa doença do olho.

Vejamos se há observações dignas de nota no emprego da lexia para cada um dos dois gêneros: 
Tabela 36 - Freqüência da questão 96 por sexo/gênero

\begin{tabular}{crrrrrr}
\hline \multirow{3}{*}{ Lexia } & \multicolumn{6}{c}{ Sexo/Gênero } \\
\cline { 2 - 7 } & \multicolumn{2}{c}{ Homens } & \multicolumn{2}{c}{ Mulheres } & \multicolumn{2}{c}{ Total } \\
\cline { 2 - 7 } & \multicolumn{1}{c}{ VA } & \multicolumn{1}{c}{ VR (\%) } & \multicolumn{1}{c}{ VA } & \multicolumn{1}{c}{ VR (\%) } & \multicolumn{1}{c}{ VA } & \multicolumn{1}{c}{ VR (\%) } \\
\hline Catarata & 2 & 33,33 & 3 & 50,00 & 5 & 41,67 \\
Abstenções & 4 & 66,67 & 3 & 50,00 & 7 & 58,33 \\
Total & $\mathbf{6}$ & $\mathbf{1 0 0 , 0 0}$ & $\mathbf{6}$ & $\mathbf{1 0 0 , 0 0}$ & $\mathbf{1 2}$ & $\mathbf{1 0 0 , 0 0}$ \\
\hline
\end{tabular}

As mulheres apresentaram um índice maior de atualização do termo especializado catarata em relação aos homens. Como o uso desta comunidade não contempla uma variante 'não-marcada', alternativa para o termo especializado, foi muito grande o número de abstenções.

Na tabela abaixo, podemos verificar o uso por faixa etária.

Tabela 37 - Frequiência da questão 96 por faixa etária

\begin{tabular}{crrrrrr}
\hline \multirow{3}{*}{ Lexia } & \multicolumn{5}{c}{ Faixa Etária } \\
\cline { 2 - 7 } & \multicolumn{2}{c}{$\mathbf{1 8}$ a 30 anos } & \multicolumn{2}{c}{ 66 anos ou mais } & \multicolumn{2}{c}{ TOTAL } \\
\cline { 2 - 7 } & VA & VR (\%) & \multicolumn{1}{c}{ VA } & VR (\%) & \multicolumn{1}{c}{ VA } & \multicolumn{1}{c}{ VR (\%) } \\
\hline Catarata & 2 & 33,33 & 3 & 50,00 & 5 & 41,67 \\
Abstenções & 4 & 66,67 & 3 & 50,00 & 7 & 58,33 \\
Total & $\mathbf{6}$ & $\mathbf{1 0 0 , 0 0}$ & $\mathbf{6}$ & $\mathbf{1 0 0 , 0 0}$ & $\mathbf{1 2}$ & $\mathbf{1 0 0 , 0 0}$ \\
\hline
\end{tabular}

Com relação à variável faixa etária, contrariamente à tendência que vimos observando, os sujeitos da segunda faixa etária, de idade mais avançada, que estão passando ou que já passaram por este problema, conhecem a forma estudada. Portanto, a maior incidência do termo especializado catarata foi nessa faixa etária. Os sujeitos da primeira faixa não souberam identificar o referente, ou não souberam atualizar sua designação. Apresentaram um índice maior de abstenção.

Vejamos agora como se distribui a lexia estudada nos pontos selecionados. 
Tabela 38 - Distribuição das lexias da questão 96 pelos pontos

\begin{tabular}{crrrrrrrr}
\hline \multirow{2}{*}{ Lexia } & \multicolumn{9}{c}{ Ponto } \\
\cline { 2 - 9 } & \multicolumn{2}{c}{ Icapara } & \multicolumn{2}{c}{ Rocio } & \multicolumn{2}{c}{ Jairê } & \multicolumn{2}{c}{ Total } \\
\cline { 2 - 9 } & \multicolumn{1}{c}{ VA } & \multicolumn{1}{c}{ VR (\%) } & \multicolumn{1}{c}{ VA } & \multicolumn{1}{c}{ VR (\%) } & \multicolumn{1}{c}{ VA } & \multicolumn{1}{c}{ VR (\%) } & \multicolumn{1}{c}{ VA } & \multicolumn{1}{c}{ VR (\%) } \\
\hline Catarata & 2 & 50,00 & 1 & 25,00 & 2 & 50,00 & 5 & 41,67 \\
Abstenções & 2 & 50,00 & 3 & 75,00 & 2 & 50,00 & 7 & 58,33 \\
Total & $\mathbf{4}$ & $\mathbf{1 0 0 , 0 0}$ & $\mathbf{4}$ & $\mathbf{1 0 0 , 0 0}$ & $\mathbf{4}$ & $\mathbf{1 0 0 , 0 0}$ & $\mathbf{1 2}$ & $\mathbf{1 0 0 , 0 0}$ \\
\hline
\end{tabular}

Os bairros Icapara e Jairê encontram-se igualmente divididos entre o emprego do termo especializado catarata e o desconhecimento do termo ou de uma variante para nomear a doença. No Rocio, a grande maioria - 3/4 dos entrevistados -, não conhece o termo que designa essa doença do olho.

Não encontramos esta questão tratada nos atlas regionais que consultamos.

\section{Análise de traços semânticos}

Para a análise da rede semêmica de catarata, recorremos aos dicionários gerais de língua portuguesa e, também aos dicionários de medicina de Coutinho (1977) e Braier (1964):

- catarata 1 queda d'água, cachoeira 2 (1670) OFT opacidade parcial ou total do cristalino ou de sua cápsula ETM lat. cataracta,ae ou cataractes,ae 'grande volume de água que se precipita do alto; catadupa', do gr. katarrhãktes,ou 'que se precipita que se atira para baixo'; f. hist. S XIV cataracta SIN/VAR ver sinonímia de queda d'água (HOUAISS, 2001, p. 650).

- catarata [Do gr. kataraktes, 'que se lança para baixo'; 'queda d'água', pelo lat. cataracta] sf. 1. queda-d'água 2. Oftalm. Perda da transparência do cristalino ou da sua cápsula (FERREIRA, 2002, p. 424).

- catarata 1 grande massa de um rio ou de um lago que se precipita de grande altura; cachoeira 2 doença ocular que torna o cristalino opaco, impedindo a chegada dos raios luminosos à retina (BORBA, 2004, p.253). 
- catarata [lat. cataracta, do gr. kata (r)áktes que cai, queda de água, taipal, dique] Opacidade parcial ou total do cristalino, estructura ocular normalmente transparente (COUTINHO, p. 423).

Em Braier (1964, p. 216), além dos semas encontrados nas definições acima, lemos:

- catarata. La forma más común es la senil, que aparece generalmente después de los cincuenta años, con mayor frecuencia en individuos alcohólicos, diabéticos, renales, etc. Kulezyka (1954) atribuye la catarata senil a una disminución del ácido ascórbico en el cristalino. La catarata diabética suele ser blanca, voluminosa y bilateral. Se ha observado la aparición de catarata en pacientes con insuficiencia paratiroidea, en caso de intoxicación por dinitrofenol y en ciertas profesiones (fogoneros, obreros de altos hornos) por la acción del calor o de la luz viva.

Catarata é mais um termo da linguagem de especialidade médica para designar uma doença do olho. De sua origem grega, herdada pelo latim, traz a noção 'que se precipita, que se atira para baixo', relativo ao referente 'queda d'água'. Portanto, trata-se de dois signos, com dois sememas: catarata $^{1}$ queda d'água, e catarata $^{2}$ doença do olho.

Aqui, num primeiro momento, enfocaremos catarata $^{2}$, cujos semas inerentes referemse recorrentemente ao cristalino, definido pelo sema "estructura ocular normalmente transparente", que é seu núcleo sêmico. O cristalino é diretamente afetado pela doença: “doença ocular que torna o cristalino opaco". O semas que se referem a perda, diminuição indicam o caráter de patologia, de doença, que se observa: "Perda da transparência do cristalino", "disminución del ácido ascórbico en el cristalino" e, como resultado, "impedindo a chegada dos raios luminosos à retina”.

Um dos semas inerentes de catarata $^{l}$ se refere à cor branca: "la catarata diabética suele ser blanca, voluminosa y bilateral”. Outro sema inerente contextualiza a faixa etária em que mais comumente se manifesta a doença: "que aparece generalmente después de los cincuenta años". 
O semema de catarata $^{1}$ reúne os semas 'grande volume de água que se precipita do alto; catadupa'; 'grande massa de um rio ou de um lago que se precipita de grande altura; cachoeira'. Podemos perceber que alguns semas inerentes de catarata $^{2}$, muito se aproximam dos de catarata $^{1}$ : o cristalino (das águas e dos olhos), o volume (referência às águas da cachoeira e à catarata ${ }^{2}$, volumosa) e branca (referência à espuma que embaça o cristalino das águas da catarata ${ }^{1}$ e à pele branca que cobre o cristalino do olho).

Essas relações de equivalência fazem aflorar, no processo interpretativo do falante/ouvinte, semas aferentes que até então permaneciam ocultos, subjacentes. De acordo com Pottier (apud SANTOS, 2005, p.2), os semas podem sofrer profundas alterações em seu estatuto, na dinâmica do discurso. Enquanto uns podem ser realizados, outros podem permanecer ocultos, devido a processos metafóricos; outros, ainda, podem ter seu espectro ampliado. Dessa forma o semema, como fato de língua que é, pode ser ampliado ou reduzido, em termos de seu espectro, ao ser atualizado no discurso.

É o que parece ter acontecido neste caso: vemos que o sema 'branca', que aparece na pergunta do QSL (“aquela pele branca no olho”), permanece oculto nas definições dos dicionários e só vai se materializar na definição de Braier: "la catarata diabética suele ser blanca, voluminosa y bilateral". O sema 'branca', que permanece subjacente ao processo de significação, e se reporta à espuma branca que se forma nas cachoeiras, é a intersecção que permite conjugar os dois sememas e gerar a metáfora, criando por neologismo semântico o termo catarata - 'doença do olho'. Pelo que se pode perceber, esse neologismo semântico ocorre quando a lexia catarata $^{1}$ migra para o universo do discurso médico, disjungindo-se e gerando o termo técnico catarata ${ }^{2}$.

Cada realização pontual deixa em aberto um conjunto de virtualidades semêmicas inexploradas, prontas para se atualizarem ao menor obstáculo que o processo linear da significação possa encontrar (GREIMAS e COURTÉS,1979, p. 253). 


\subsection{Boca}

Analisaremos a seguir as questões de $\mathrm{n}^{\circ} 97$ a 100, referentes a boca, parte integrante da cabeça. Na verdade, essas questões dizem respeito apenas aos dentes.

Essa classe semântica, como Rastier (1987) denomina uma esfera semântica, relativa aos dentes reflete, como não poderia deixar de ser, a cultura e os costumes de vários povos e civilizações.

De acordo com pesquisa de Cascudo (1973, p. 248), os dentes eram limados, arrancados:

Os dentes começaram a sofrer mutilações (ornamento, luto, iniciação) desde o neolítico; Argélia, Egito, Lancashire e País de Gales, constatadas nos crânios fósseis. Para a África Central e Austral, golfo da Guiné, arquipélago malaio, Filipinas, México, Equador, Peru, Argentina, Brasil, Chaco boliviano e paraguaio aparecem aguçados, arrancados (tipicamente africanos), limados lateral ou triangularmente, com blocos de ouro ou prata em forma de placas ou bastões. (...) Foi costume de alto gosto, europeu e americano, o dente de ouro, incisivos, caninos, molares, cobertos de folhas de ouro. (...)

Os dentes também sempre foram usados para proteger e dar sorte:

Os dentes são amuleto e os do tubarão fóssil serviam na Idade Média de pierre d'épreuve, denunciando a existência do veneno nas iguarias aristocráticas. São ainda utilizados na Península Ibérica e América Latina como protetores da dentição infantil, encastoados em ouro, pendentes do pescoço. O primeiro dente-de-leite arrancado deve ser atirado para trás, por cima do ombro, para o alto do telhado, propiciando dente novo e são. É assunto estudado pelos folcloristas.

Como ornamento, até hoje os dentes são usados em pingentes:

O colar de dentes de felídeos, ursídeos e mesmo humanos foi desde o aurinhacense um ornamento preferido e encontrado nos depósitos arqueológicos mais distantes. Continua popular na Polinésia, Melanésia, Américas Central e do Sul e as velhas famílias indígenas dos Estados Unidos e Canadá têm a mesma predileção por eles.

Para punir um infrator ou ficar com um símbolo do inimigo abatido, uma tradição

Já velhíssima no século X pela Europa (e anterior no Oriente) era arrancar os dentes a quem prestava depoimento falso. Faziam ablação de 1/5, 1/4, 1/3 dos dentes segundo a gravidade da culpa. "Mentir por todos os dentes" é uma alusão. Santa Rita Durão informa que os grandes guerreiros faziam colares dos dentes dos inimigos devorados (Caramuru, IV, 15):

Devora vivos na batalha ardente;

À roda do pescoço um fio enlaça,

Onde, de quantos come, enfia um dente. 
Na pena de talião mosaica (Êxodo, XXI, 24), continua Cascudo (1973, p.248), aludese ao "olho por olho, dente por dente". Por outro lado, entre os ainos do norte do Japão, a dentada é a mais expressiva demonstração amorosa.

Era tabu ver o outro comendo:

A mastigação caracteriza o ato de comer e era nesse momento que o tabu incidia, proibindo-se olhar quem se alimentava, especialmente os soberanos africanos, asiáticos, ameríndios.

Uma aura de magia envolve os dentes e a mordida. Há magias terapêuticas:

Morder é também um processo da magia terapêutica. Os feiticeiros africanos, Guiné, Congo, Nigéria, do Senegal ao Cabo da Boa Esperança, entre os remédios para reduzir inchações, incluem a dentada. Em Portugal os lobinhos (quistos subcutâneos) são curados quando mordidos por uma donzela de nome Maria. Os mestres, pais de terreiro, babalorixás dos candomblés, macumbas, xangôs, catimbós do Brasil preparam certos amuletos mordendo-os ao final.

\subsubsection{Dentes Caninos}

QUESTÃO 97 - ... esses dois dentes pontudos? Apontar.

\section{Freqüência e distribuição}

A tabela a seguir reúne as respostas à questão nº 97 :

\section{Tabela 39 - Freqüência geral da questão 97- Iguape}

\begin{tabular}{lrr}
\hline \multirow{2}{*}{ Lexia } & \multicolumn{2}{c}{ Freqüência } \\
\cline { 2 - 3 } & \multicolumn{1}{c}{ VA } & \multicolumn{1}{c}{ VR (\%) } \\
\hline Presas & 6 & 50,00 \\
Caninos & 3 & 25,00 \\
Abstenções & 3 & 25,00 \\
\multicolumn{1}{c}{ Total } & $\mathbf{1 2}$ & $\mathbf{1 0 0 , 0 0}$ \\
\hline
\end{tabular}

A lexia presas foi selecionada por metade dos entrevistados em Iguape. A outra metade dos sujeitos ficou dividida entre a forma caninos e a abstenção. 
Tabela 40 - Freqüiência da questão 97 por sexo/gênero

\begin{tabular}{lrrrrrr}
\hline \multirow{2}{*}{ Lexia } & \multicolumn{6}{c}{ Sexo/Gênero } \\
\cline { 2 - 7 } & \multicolumn{2}{c}{ Homens } & \multicolumn{2}{c}{ Mulheres } & \multicolumn{2}{c}{ Total } \\
\cline { 2 - 7 } & \multicolumn{1}{c}{ VA } & \multicolumn{1}{c}{ VR (\%) } & \multicolumn{1}{c}{ VA } & \multicolumn{1}{c}{ VR (\%) } & \multicolumn{1}{c}{ VA } & \multicolumn{1}{c}{ VR (\%) } \\
\hline Presas & 2 & 33,33 & 4 & 66,67 & 6 & 50,00 \\
Caninos & 1 & 16,67 & 2 & 33,33 & 3 & 25,00 \\
Abstenções & 3 & 50,00 & 0 & 0,00 & 3 & 25,00 \\
TOTAL & $\mathbf{6}$ & $\mathbf{1 0 0 , 0 0}$ & $\mathbf{6}$ & $\mathbf{1 0 0 , 0 0}$ & $\mathbf{1 2}$ & $\mathbf{1 0 0 , 0 0}$ \\
\hline
\end{tabular}

Contrariamente à tendência assinalada em outras questões, quanto ao emprego de termo da linguagem de especialidade ou da língua comum, as mulheres não deram preferência ao termo especializado dente canino para designar essa parte do corpo. Dessa vez, elas fizeram uso da variante não-marcada, mais popular, presas. Quanto aos sujeitos do gênero masculino, o maior percentual foi de abstenções, depois vem a variante não-marcada, e, por último o termo especializado.

Na tabela abaixo, podemos verificar o uso por faixa etária.

\section{Tabela 41 - Freqüência da questão 97 por faixa etária}

\begin{tabular}{lrrrrrr}
\hline \multirow{2}{*}{ Lexia } & \multicolumn{5}{c}{ Faixa Etária } \\
\cline { 2 - 7 } & \multicolumn{2}{c}{$\mathbf{1 8}$ a 30 anos } & \multicolumn{3}{c}{ 66 anos ou mais } & \multicolumn{2}{c}{ Total } \\
\cline { 2 - 7 } & \multicolumn{1}{c}{ VA } & \multicolumn{1}{c}{ VR $(\boldsymbol{\%})$} & \multicolumn{1}{c}{ VA } & \multicolumn{1}{c}{ VR $(\boldsymbol{\%})$} & \multicolumn{1}{c}{ VA } & \multicolumn{1}{c}{ VR (\%) } \\
\hline Presas & 1 & 16,67 & 5 & 83,33 & 6 & 50,00 \\
Caninos & 3 & 50,00 & 0 & 0,00 & 3 & 25,00 \\
Abstenções & 2 & 33,33 & 1 & 16,67 & 3 & 25,00 \\
$\quad$ Total & $\mathbf{6}$ & $\mathbf{1 0 0 , 0 0}$ & $\mathbf{6}$ & $\mathbf{1 0 0 , 0 0}$ & $\mathbf{1 2}$ & $\mathbf{1 0 0 , 0 0}$ \\
\hline
\end{tabular}

Pelos dados da tabela, podemos ver que os responsáveis pelo uso e conservação da lexia presas, em Iguape, são os sujeitos de mais de 66 anos. A metade dos jovens da $1^{\text {a }}$ faixa etária emprega o termo da linguagem de especialidade da anatomia odontológica.

Tabela 42 - Distribuição das lexias da questão 97 pelos pontos

\begin{tabular}{lrrrrrrrr}
\hline \multirow{2}{*}{ Lexia } & \multicolumn{9}{c}{ Ponto } \\
\cline { 2 - 9 } & \multicolumn{2}{c}{ Icapara } & \multicolumn{2}{c}{ Rocio } & \multicolumn{2}{c}{ Jairê } & \multicolumn{2}{c}{ Total } \\
\cline { 2 - 9 } & \multicolumn{1}{c}{ VA } & \multicolumn{1}{c}{ VR (\%) } & \multicolumn{1}{c}{ VA } & \multicolumn{1}{c}{ VR (\%) } & \multicolumn{1}{c}{ VA } & \multicolumn{1}{c}{ VR (\%) } & \multicolumn{1}{c}{ VA } & \multicolumn{1}{c}{ VR (\%) } \\
\hline Presas & 2 & 50,00 & 2 & 50,00 & 2 & 50,00 & 6 & 50,00 \\
Caninos & 1 & 25,00 & 1 & 25,00 & 1 & 25,00 & 3 & 25,00 \\
Abstenções & 1 & 25,00 & 1 & 25,00 & 1 & 25,00 & 3 & 25,00 \\
$\quad$ Total & $\mathbf{4}$ & $\mathbf{1 0 0 , 0 0}$ & $\mathbf{4}$ & $\mathbf{1 0 0 , 0 0}$ & $\mathbf{4}$ & $\mathbf{1 0 0 , 0 0}$ & $\mathbf{1 2}$ & $\mathbf{1 0 0 , 0 0}$ \\
\hline
\end{tabular}


A distribuição das lexias se dá exatamente da mesma maneira nos três pontos selecionados para a pesquisa, em Iguape. Dos quatro sujeitos de cada um dos bairros, Icapara, Rocio e Jairê, metade usou a lexia presas, um quarto usou caninos e outro tanto absteve-se.

Não encontramos esta questão tratada nos atlas regionais que consultamos.

\section{Análise de traços semânticos}

Selecionamos abaixo os sememas da lexia presas, pesquisadas em dicionários gerais de língua portuguesa e o de medicina, de Coutinho (1977):

- canino ANAT ODONT dente pontudo e perfurante, situado entre o incisivo lateral e o pré-molar, em número de dois em cada maxilar, que permite rasgar os alimentos $\leftrightarrow$ tb se diz apenas canino (HOUAISS, 2001, p. 939).

- canino [Do lat. caninu] Adjetivo.1. Referente a, ou próprio de cão ${ }^{1}$ (1). V. dente - e fome -a.Substantivo masculino. 2.V. dente(1):“- Como é, doutor, não reconhece? - perguntou o José da Estação com dois caninos risonhos na gengiva vermelha." (Ribeiro Couto, Cabocla, p. 16.) (FERREIRA, dic. eletr.).

- canino (DENTE) [lat. caninus de cão] - cada um dos quatro dentes situados entre os incisivos laterais e os quatro primeiros pré-molares (COUTINHO, p. 400)

- canino 1 relativo a cão 2 próprio, típico de cão 3 voraz Sm. 4 cada um dos quatro dentes laterais dos mamíferos, mais compridos que os demais e pontiagudos (BORBA, 2004, p. 231).

- presa sf. 1 bem apreendido do inimigo; espólio, despojo 2 animal ou pessoa arrebatados ou apreendidos com violência 3 prisioneiro; vítima; 4 dente canino (BORBA, 2004, p. 1115).

Dente canino é termo da linguagem de especialidade da Anatomia Odontológica, segundo lemos na rubrica usada por Houaiss. Como termo, ele é monossemêmico, sua definição é unívoca: seus semas inerentes 'dente pontudo e perfurante' e 'mais compridos que 
os demais e pontiagudos', particularizam e distinguem esse dente dos demais. E justificam a associação do nome deste dente, pelas suas características e morfologia, ao dente dos cães. Aliás, são os dentes dos 'mamíferos', inclua-se aí o homem, e também dos carnívoros, pois entre suas funções está a expressa pelo sema 'que permite rasgar os alimentos', que nos permite supor que o alimento em questão é a carne. O dente canino é, então, uma ferramenta natural dos animais carnívoros.

Por fim, vemos que canino é parassinônimo de $\operatorname{presa}(s)$, sendo que esta lexia pertence à língua comum, e talvez por isso mesmo seja muito mais transparente, evidencie mais o traço 'animal', /+voraz/. Mais que a própria lexia dente canino, que traz acoplado o adjetivo derivado de cão. Elas não são comutáveis em todos os contextos.

Um capítulo notadamente importante da Semântica envolve as comparações metafóricas. São valiosas as indicações que ela oferece sobre a ação da fantasia (entenda-se inferência) sobre o inconsciente coletivo. No caso de dente canino, como falamos, explica-se a comparação pela forma e função dessa parte do corpo humano. Abaixo temos exemplos de comparações que refletem interessantes pontos de vista de cada povo ao nomear seus objetos de trabalho, por exemplo. São figuras de animais associadas a ferramentas criadas pelo homem.

Se observarmos atentamente a língua dos artesãos e dos aldeães, encontraremos nela uma tendência a comparar suas ferramentas de trabalho com figuras de animais. Assim, os "morillos del fuego" na França têm o nome de cachorro (chenet), da cabra (chevrette), do asno (provençal ase), do gato (minet), da cabra (landier). (...) A chave para dar saída à água de um tubo, em espanhol se chama grifo, em francês robinet 'carneiro', na Sicília, aceddu 'pássaro', em alemão Hahn 'galo'. O disparador das armas de fogo para os espanhóis é gatillo, ou perrillo, para os italianos e franceses é cachorro (cane, chien), para os gregos um lobo, para os alemães, iugoslavos e bascos um galo (Hahn, òroz, ollar) (ROHLFS, 1979, p. 46).

Às animalizações se associam personificações nas quais se pode reconhecer o mesmo princípio da denominação. Em Viena se designa com Mandeln ('homenzinhos') $e$ Weibeln ('mulherzinhas') $a$ 'corchete' $e$ 'corcheta'. Em alemão, Mönch 'monje' e Nonne 'monja' são 'uma espécie de ladrilhos ocos que encaixam um no outro'. 


\subsubsection{Dentes do siso/do juízo}

QUESTÃO 98 - ... os últimos dentes, que nascem depois de todos os outros, em geral quando a pessoa já é adulta?

\section{Freqüência e distribuição}

A Tabela 43 reúne as respostas à questão $n^{\circ} 98$.

Tabela 43 - Freqüiência geral da questão 98- Iguape

\begin{tabular}{lrr}
\hline \multirow{2}{*}{ Lexia } & \multicolumn{2}{c}{ Freqüência } \\
\cline { 2 - 3 } & VA & \multicolumn{1}{c}{ VR (\%) } \\
\hline Dente do siso & 9 & 75,00 \\
Dente do juízo & 1 & 8,33 \\
Abstenções & 2 & 16,67 \\
TOTAL & $\mathbf{1 2}$ & $\mathbf{1 0 0 , 0 0}$ \\
\hline
\end{tabular}

A lexia complexa dente do siso é de uso massivo em Iguape.

Tabela 44 - Freqüiência da questão 98 por sexo/gênero

\begin{tabular}{lrrrrrr}
\hline \multirow{2}{*}{ Lexia } & \multicolumn{6}{c}{ Sexo/Gênero } \\
\cline { 2 - 7 } & \multicolumn{2}{c}{ Homens } & \multicolumn{2}{c}{ Mulheres } & \multicolumn{2}{c}{ Total } \\
\cline { 2 - 8 } & \multicolumn{1}{c}{ VA } & \multicolumn{1}{c}{ VR (\%) } & \multicolumn{1}{c}{ VA } & \multicolumn{1}{c}{ VR (\%) } & \multicolumn{1}{c}{ VA } & \multicolumn{1}{c}{ VR (\%) } \\
\hline Dente do siso & 4 & 66,67 & 5 & 83,33 & 9 & 75,00 \\
Dente do juízo & 0 & 0,00 & 1 & 16,67 & 1 & 8,33 \\
Abstenções & 2 & 33,33 & 0 & 0,00 & 2 & 16,67 \\
TOTAL & $\mathbf{6}$ & $\mathbf{1 0 0 , 0 0}$ & $\mathbf{6}$ & $\mathbf{1 0 0 , 0 0}$ & $\mathbf{1 2}$ & $\mathbf{1 0 0 , 0 0}$ \\
\hline
\end{tabular}

As mulheres apresentam um índice pouco maior em termos da utilização da lexia dente do siso, em relação aos homens. Entre elas, nenhuma se absteve de responder, e uma usou o parassinônimo dente do juízo. Os homens, por sua vez, não selecionaram a variante dente do juízo. 
Tabela 45 - Freqüiência da questão 98 por faixa etária

\begin{tabular}{lrrrrrr}
\hline \multirow{2}{*}{ Lexia } & \multicolumn{6}{c}{ Faixa Etária } \\
\cline { 2 - 7 } & \multicolumn{1}{c}{$\mathbf{1 8}$ a 30 anos } & \multicolumn{6}{c}{ 66 anos ou mais } & \multicolumn{2}{c}{ Total } \\
\cline { 2 - 7 } & \multicolumn{1}{c}{ VA } & VR (\%) & \multicolumn{1}{c}{ VA } & VR (\%) & \multicolumn{1}{c}{ VA } & \multicolumn{1}{c}{ VR (\%) } \\
\hline Dente do siso & 4 & 66,67 & 5 & 83,33 & 9 & 75,00 \\
Dente do & & & & & & \\
juízo & 0 & 0,00 & 1 & 16,67 & 1 & 8,33 \\
Abstenções & 2 & 33,33 & 0 & 0,00 & 2 & 16,67 \\
$\quad$ & $\mathbf{6}$ & $\mathbf{1 0 0 , 0 0}$ & $\mathbf{6}$ & $\mathbf{1 0 0 , 0 0}$ & $\mathbf{1 2}$ & $\mathbf{1 0 0 , 0 0}$ \\
\hline
\end{tabular}

O maior índice de atualização da lexia dente do siso encontra-se na segunda faixa etária, o que significa que a lexia está memorizada pelos mais idosos. Também os mais jovens utilizam-na bastante, o que significa vitalidade da forma.

Tabela 46 - Distribuição das lexias da questão 98 pelos pontos

\begin{tabular}{lrrrrrrrr}
\hline \multirow{2}{*}{ Lexia } & \multicolumn{8}{c}{ Ponto } \\
\cline { 2 - 9 } & \multicolumn{2}{c}{ Icapara } & \multicolumn{2}{c}{ Rocio } & \multicolumn{2}{c}{ Jairê } & \multicolumn{2}{c}{ Total } \\
\cline { 2 - 9 } & \multicolumn{1}{c}{ VA } & \multicolumn{1}{c}{ VR (\%) } & \multicolumn{1}{c}{ VA } & \multicolumn{1}{c}{ VR (\%) } & VA & \multicolumn{1}{c}{ VR (\%) } & \multicolumn{1}{c}{ VA } & \multicolumn{1}{c}{ VR (\%) } \\
\hline Dente do siso & 2 & 50,00 & 2 & 50,00 & 2 & 50,00 & 6 & 50,00 \\
Dente do juízo & 1 & 25,00 & 1 & 25,00 & 1 & 25,00 & 3 & 25,00 \\
Abstenções & 1 & 25,00 & 1 & 25,00 & 1 & 25,00 & 3 & 25,00 \\
\multicolumn{1}{c}{ TOTAL } & $\mathbf{4}$ & $\mathbf{1 0 0 , 0 0}$ & $\mathbf{4}$ & $\mathbf{1 0 0 , 0 0}$ & $\mathbf{4}$ & $\mathbf{1 0 0 , 0 0}$ & $\mathbf{1 2}$ & $\mathbf{1 0 0 , 0 0}$ \\
\hline
\end{tabular}

Percebe-se que nos três pontos, Icapara, Rocio e Jairê, as variantes lexicais têm exatamente a mesma distribuição.

Tabela 47 - Comparação da variação lexical da questão 98: Iguape - Outros atlas regionais

\begin{tabular}{|c|c|c|c|c|c|c|}
\hline \multirow{2}{*}{ Lexia } & \multirow{2}{*}{ Município de Iguape } & \multicolumn{4}{|c|}{ Atlas } & \multirow{2}{*}{ Total } \\
\hline & & ALPR & APFB & ALS & ALMS & \\
\hline Dente queiro & & $\mathbf{X}$ & $\mathbf{X}$ & $\mathbf{X}$ & $\mathbf{X}$ & 4 \\
\hline Dente do siso & $\mathbf{X}$ & $\mathbf{X}$ & & & $\mathbf{X}$ & 3 \\
\hline Dente do juízo & $\mathbf{X}$ & $\mathbf{X}$ & & & $\mathbf{X}$ & 3 \\
\hline Dente de leite & & $\mathbf{X}$ & & & & 1 \\
\hline Curnio & & $\mathbf{X}$ & & & & 1 \\
\hline Pilão & & & & & $\mathbf{X}$ & 1 \\
\hline Quexa(l) & & & & & $\mathbf{X}$ & 1 \\
\hline Total & 2 & 5 & 1 & 1 & 5 & \\
\hline
\end{tabular}


Como podemos observar, a questão sobre dente do siso reuniu diversas variantes lexicais, em várias regiões do Brasil, registradas nos atlas pesquisados. A lexia dente queiro, de maior freqüência no confronto com as demais regiões, não foi registrada em Iguape.

\section{Análise de traços semânticos}

Selecionamos abaixo as acepções do verbete dente e dente do siso em vários dicionários gerais de língua portuguesa:

- Dente s.m. 'cada um dos órgãos duros que guarnecem as maxilas do homem e outros animais'. XIII. Do lat. dens,-entis; desdentado, XVI (CUNHA, 1986, p. 247).

- Dente [Do lat. dente.] Substantivo masculino. 1. Anat. Cada uma das peças duras, semelhantes a osso, que guarnecem os maxilares e mandíbula do homem e doutros animais, e servem especialmente para morder e triturar alimentos (FERREIRA, dic. eletr.).

- Siso - 1 bom senso; juízo; 2 prudência; 3 jogo popular em que duas pessoas se fixam atentamente, perdendo aquela que rir primeiro 4 o último dos dentes molares que nasce na idade adulta (BORBA, 2004, p. 1293).

- dente de siso ANAT ODONT cada um dos terceiros dentes molares que surgem ger. entre os 17 e os 21 anos de idade; dente do juízo $\rightarrow$ tb se diz apenas siso./ Dente queiro B NE m.q. dente de siso (HOUAISS, 2001, p. 939).

- siso [Do lat. sensu, 'sentido', pelo arc. seso.] Substantivo masculino. 1. Bom senso; juízo, tino, prudência, circunspeção: "Muito riso, pouco siso" (prov.) 2.V. dente de siso. De siso. 1. Sensatamente (FERREIRA, dic. eletr.).

O termo técnico da linguagem de especialidade da odontologia, dente do siso, é parassinônimo de dente do juízo, variante dialetal da língua comum.

Os semas inerentes de dente do siso, e também de dente do juízo, definem sua função 'servem especialmente para morder e triturar alimentos' e, mais que isso, descrevem sua 
característica principal: o fato de 'que surgem ger. entre os 17 e os 21 anos de idade', ou seja, 'que nasce na idade adulta', daí a designação dente do siso conduzir à inferência de que esse dente nasce quando a pessoa já tem juízo. As variantes, quanto ao continuum cientificidade, de um lado, e banalização, de outro, devem se encontrar no meio do caminho, no meio termo.

Encontramos a seguinte explicação para a variante queiro, encontrada nos atlas regionais consultados e constantes da Tabela 48: em Ferreira (dic. eletr.) queiro-“[Talvez de queixeiro, com síncope.]". Encontrada em todo o nordeste brasileiro, como registra Houaiss, a lexia dente queiro também é selecionada para referir o dente molar, localizados, ambos, lado a lado, no fundo da boca, na região do queixo. Daí ser possível a hipótese de Ferreira de queiro ser derivado de queixo > queixeiro, com síncope.

\subsubsection{Dentes molares/dente queiro}

QUESTÃO 99 - ... esses dentes grandes no fundo da boca, vizinhos dos item 98)? Apontar.

\section{Freqüiência e distribuição}

Tabela 48 - Freqüência geral da questão 99- Iguape

\begin{tabular}{lrr}
\hline \multirow{2}{*}{ Lexia } & \multicolumn{2}{c}{ Freqüência } \\
\cline { 2 - 3 } & VA & \multicolumn{1}{c}{ VR (\%) } \\
\hline Queixal & 3 & 25,00 \\
Molar & 3 & 25,00 \\
Mastigador & 1 & 8,33 \\
Abstenções & 5 & 41,67 \\
\multicolumn{1}{c}{ Total } & $\mathbf{1 2}$ & $\mathbf{1 0 0 , 0 0}$ \\
\hline
\end{tabular}

O que se conclui pelos dados da Tabela 49 é que o iguapense utiliza outras designações para referir os dentes grandes e chatos no fundo da boca. Novamente temos a seleção de uma lexia, mastigador, mais motivada semanticamente para o falante /ouvinte. 
Tabela 49 - Frequiência da questão 99 por sexo/gênero

\begin{tabular}{lrrrrrr}
\hline \multirow{3}{*}{ Lexia } & \multicolumn{6}{c}{ Sexo/Gênero } \\
\cline { 2 - 7 } & \multicolumn{2}{c}{ Homens } & \multicolumn{2}{c}{ Mulheres } & \multicolumn{2}{c}{ Total } \\
\cline { 2 - 7 } & \multicolumn{1}{c}{ VA } & \multicolumn{1}{c}{ VR (\%) } & \multicolumn{1}{c}{ VA } & \multicolumn{1}{c}{ VR (\%) } & \multicolumn{1}{c}{ VA } & \multicolumn{1}{c}{ VR (\%) } \\
\hline Queixal & 1 & 16,67 & 2 & 33,33 & 3 & 25,00 \\
Molar & 0 & 0,00 & 3 & 50,00 & 3 & 25,00 \\
Mastigador & 1 & 16,67 & 0 & 0,00 & 1 & 8,33 \\
Abstenções & 4 & 66,67 & 1 & 16,67 & 5 & 41,67 \\
\multicolumn{1}{r}{ Total } & $\mathbf{6}$ & $\mathbf{1 0 0 , 0 0}$ & $\mathbf{6}$ & $\mathbf{1 0 0 , 0 0}$ & $\mathbf{1 2}$ & $\mathbf{1 0 0 , 0 0}$ \\
\hline
\end{tabular}

As mulheres assimilam bem melhor que os homens os termos especializados, é o que mais uma vez se verifica. Neste caso não se trata nem de os homens optarem pelo banal ou vulgar, mas de não responderem à questão, se considerarmos o índice elevado de abstenções.

Tabela 50 - Freqüência da questão 99 por faixa etária

\begin{tabular}{lrrrrrr}
\hline \multirow{2}{*}{ Lexia } & \multicolumn{6}{c}{ Faixa Etária } \\
\cline { 2 - 7 } & \multicolumn{1}{c}{$\mathbf{1 8}$ a 30 anos } & \multicolumn{6}{c}{ 66 anos ou mais } & \multicolumn{2}{c}{ Total } \\
\cline { 2 - 7 } & VA & VR (\%) & \multicolumn{1}{c}{ VA } & VR (\%) & \multicolumn{1}{c}{ VA } & \multicolumn{1}{c}{ VR (\%) } \\
\hline Queixal & 0 & 0,00 & 3 & 50,00 & 3 & 25,00 \\
Molar & 3 & 50,00 & 0 & 0,00 & 3 & 25,00 \\
Mastigador & 1 & 16,67 & 0 & 0,00 & 1 & 8,33 \\
Abstenções & 2 & 33,33 & 3 & 50,00 & 5 & 41,67 \\
\multicolumn{1}{r}{ Total } & $\mathbf{6}$ & $\mathbf{1 0 0 , 0 0}$ & $\mathbf{6}$ & $\mathbf{1 0 0 , 0 0}$ & $\mathbf{1 2}$ & $\mathbf{1 0 0 , 0 0}$ \\
\hline
\end{tabular}

Novamente se confirma: os jovens empregam mais o termo técnico científico, no caso molar, e os mais velhos dão preferência pelo termo banalizado queixal.

Tabela 51 - Distribuição das lexias da questão 99 pelos pontos

\begin{tabular}{lrrrrrrrr}
\hline \multirow{2}{*}{ Lexia } & \multicolumn{9}{c}{ Ponto } \\
\cline { 2 - 9 } & \multicolumn{2}{c}{ Icapara } & \multicolumn{2}{c}{ Rocio } & \multicolumn{2}{c}{ Jairê } & \multicolumn{2}{c}{ Total } \\
\cline { 2 - 10 } & VA & \multicolumn{1}{c}{ VR (\%) } & \multicolumn{1}{c}{ VA } & \multicolumn{1}{c}{ VR (\%) } & VA & \multicolumn{1}{c}{ VR (\%) } & \multicolumn{1}{c}{ VA } & \multicolumn{1}{c}{ VR (\%) } \\
\hline Queixal & 2 & 50,00 & 0 & 0,00 & 1 & 25,00 & 3 & 25,00 \\
Molar & 1 & 25,00 & 1 & 25,00 & 1 & 25,00 & 3 & 25,00 \\
Mastigador & 0 & 0,00 & 1 & 25,00 & 0 & 0,00 & 1 & 8,33 \\
Abstenções & 1 & 25,00 & 2 & 50,00 & 2 & 50,00 & 5 & 41,67 \\
Total & $\mathbf{4}$ & $\mathbf{1 0 0 , 0 0}$ & $\mathbf{4}$ & $\mathbf{1 0 0 , 0 0}$ & $\mathbf{4}$ & $\mathbf{1 0 0 , 0 0}$ & $\mathbf{1 2}$ & $\mathbf{1 0 0 , 0 0}$ \\
\hline
\end{tabular}

O termo banalizado queixal, de maior incidência em Iguape, concentrou mais ocorrências em Icapara, depois no Jairê, e, no Rocio, não houve registro de ocorrência. 


\section{Análise de traços semânticos}

Abaixo relacionamos as acepções de queixal e molar em dicionários gerais de língua portuguesa e de especialidade:

- Queixal 1 dente molar inferior: O dentista botou óleo-de-cravo no último queixal. 2. queixo (BORBA, 2004, p. 1157).

- Queixal [De queixo+-al ${ }^{1}$.] Adjetivo de dois gêneros. 1. Do, ou pertencente ou relativo ao queixo. Substantivo masculino. 2.Dente molar (FERREIRA, dic. eletr.).

- molar ANAT ODONT cada um dos dentes situados nas partes média e posterior dos maxilares, que permitem esmagar os alimentos, em número de seis em cada maxilar, divididos em primeiro, segundo e terceiro molar $\rightarrow$ tb se diz apenas molar (HOUAISS, 2001, p. 939).

- molar [Do lat. molare, 'de moinho'.] Adjetivo de dois gêneros. 1. Próprio para moer; que mói: pedras molares. $\sim \mathrm{V}$. dente - Substantivo masculino. 2.V. dente (1) (FERREIRA, dic. eletr.).

- molar [lat. molaris mó, dente molar] Que mói, que serve para moer. Dente molar _ Cada um dos três últimos dentes de cada lado dos maxilares (COUTINHO, p. 1508)

A princípio, pensamos que queixal e molar não fossem parassinônimos, que não fossem comutáveis em todos os contextos, pois o sema inerente de queixal apresentado por Borba, 'dente molar inferior', é elemento diferencial, que disjunge os dois sememas. Entende-se por essa definição que queixal só se refere ao dente molar do maxilar inferior, associado a queixo. Mas, por isso mesmo, eles são parassinônimos. As definições encontradas nos dicionários recolocam a questão nos trilhos: queixal e molar são variantes diatópicas do mesmo conceito. Enquanto o núcleo sêmico de queixal é 'relativo ao queixo', o de molar é ‘que mói’, ‘que serve para moer', '(dentes) que permitem esmagar os alimentos'. 
A lexia complexa dente molar também pertence à linguagem de especialidade da odontologia. Já queixal pertence à língua comum e se revela bastante transparente, muito mais motivada semanticamente para o falante/ouvinte do que molar. Difícil para o falante/ouvinte seguir a linha, o processo da significação que o leva a interpretar molar, a associar molar a ‘que mói’ e à função ‘próprio para moer’. Demanda muito esforço para a busca, no banco de memória. Quando ela não resulta inútil!

Mais motivada ainda é a lexia mastigador, que o vulgo deve ter criado para designar o molar e se fazer entender diretamente.

\subsubsection{Desdentado/banguela}

QUESTÃO 100 - ... a pessoa que não tem dentes?

\section{Freqüiência e distribuição}

Tabela 52 - Freqüência geral da questão 100- Iguape

\begin{tabular}{lrr}
\hline \multirow{2}{*}{ Lexia } & \multicolumn{2}{c}{ Freqüência } \\
\cline { 2 - 3 } & VA & \multicolumn{1}{c}{ VR (\%) } \\
\hline Banguela & 9 & 75,00 \\
Desdentado & 1 & 8,33 \\
Gengiva & 1 & 8,33 \\
Abstenções & 1 & 8,33 \\
$\quad$ Total & $\mathbf{1 2}$ & $\mathbf{1 0 0 , 0 0}$ \\
\hline
\end{tabular}

Em Iguape, a freqüência da lexia banguela é bem representativa. Ela constitui uma norma semântico-lexical da localidade. 
Tabela 53 - Freqüência da questão 100 por sexo/gênero

\begin{tabular}{lrrrrrr}
\hline \multirow{2}{*}{ Lexia } & \multicolumn{6}{c}{ Sexo/Gênero } \\
\cline { 2 - 7 } & \multicolumn{2}{c}{ Homens } & \multicolumn{2}{c}{ Mulheres } & \multicolumn{2}{c}{ Total } \\
\cline { 2 - 7 } & VA & \multicolumn{1}{c}{ VR (\%) } & \multicolumn{1}{c}{ VA } & \multicolumn{1}{c}{ VR (\%) } & \multicolumn{1}{c}{ VA } & \multicolumn{1}{c}{ VR (\%) } \\
\hline Banguela & 5 & 83,33 & 4 & 66,67 & 9 & 75,00 \\
Desdentado & 1 & 16,67 & 0 & 0,00 & 1 & 8,33 \\
Gengiva & 0 & 0,00 & 1 & 16,67 & 1 & 8,33 \\
Abstenções & 0 & 0,00 & 1 & 16,67 & 1 & 8,33 \\
Total & $\mathbf{6}$ & $\mathbf{1 0 0 , 0 0}$ & $\mathbf{6}$ & $\mathbf{1 0 0 , 0 0}$ & $\mathbf{1 2}$ & $\mathbf{1 0 0 , 0 0}$ \\
\hline
\end{tabular}

Homens e mulheres usam indistintamente a lexia banguela com freqüência, apresentando os homens ligeira vantagem sobre as mulheres.

\section{Tabela 54 - Frequiência da questão 100 por faixa etária}

\begin{tabular}{lrrrrrr}
\hline \multirow{2}{*}{ Lexia } & \multicolumn{6}{c}{ Faixa Etária } \\
\cline { 2 - 7 } & \multicolumn{2}{c}{$\mathbf{1 8}$ a 30 anos } & \multicolumn{2}{c}{ 66 anos ou mais } & \multicolumn{2}{c}{ Total } \\
\cline { 2 - 7 } & VA & VR (\%) & \multicolumn{1}{c}{ VA } & VR (\%) & \multicolumn{1}{c}{ VA } & \multicolumn{1}{c}{ VR (\%) } \\
\hline Banguela & 5 & 83,33 & 4 & 66,67 & 9 & 75,00 \\
Desdentado & 1 & 16,67 & 0 & 0,00 & 1 & 8,33 \\
Gengiva & 0 & 0,00 & 1 & 16,67 & 1 & 8,33 \\
Abstenções & 0 & 0,00 & 1 & 16,67 & 1 & 8,33 \\
$\quad$ Total & $\mathbf{6}$ & $\mathbf{1 0 0 , 0 0}$ & $\mathbf{6}$ & $\mathbf{1 0 0 , 0 0}$ & $\mathbf{1 2}$ & $\mathbf{1 0 0 , 0 0}$ \\
\hline
\end{tabular}

Também quanto à variável faixa etária a frequiência de uso da lexia banguela está bastante equilibrada. Há uma leve predominância de uso pelos sujeitos da primeira faixa etária.

Tabela 55 - Distribuição das lexias da questão 100 pelos pontos

\begin{tabular}{|c|c|c|c|c|c|c|c|c|}
\hline \multirow{3}{*}{ Lexia } & \multicolumn{8}{|c|}{ Ponto } \\
\hline & \multicolumn{2}{|c|}{ Icapara } & \multicolumn{2}{|c|}{ Rocio } & \multicolumn{2}{|c|}{ Jairê } & \multicolumn{2}{|c|}{ Total } \\
\hline & VA & VR (\%) & VA & VR (\%) & VA & $\operatorname{VR}(\%)$ & VA & VR (\%) \\
\hline Banguela & 2 & 50,00 & 4 & 100,00 & 3 & 75,00 & 9 & 75,00 \\
\hline Desdentado & 1 & 25,00 & 0 & 0,00 & 0 & 0,00 & 1 & 8,33 \\
\hline Gengiva & 0 & 0,00 & 0 & 0,00 & 1 & 25,00 & 1 & 8,33 \\
\hline Abstenções & 1 & 25,00 & 0 & 0,00 & 0 & 0,00 & 1 & 8,33 \\
\hline Total & 4 & 100,00 & 4 & 100,00 & 4 & 100,00 & 12 & 100,00 \\
\hline
\end{tabular}

A lexia banguela é amplamente utilizada no Rocio e bem freqüente no Jairê. Dos sujeitos pesquisados em Icapara, 50\% fez uso dessa lexia. 
Tabela 56 - Comparação da variação lexical da questão 100: Iguape - Outros atlas regionais

\begin{tabular}{lccccc}
\hline \multirow{2}{*}{ Lexia } & \multirow{2}{*}{ Município de Iguape } & \multicolumn{3}{c}{ Atlas } & \multirow{2}{*}{ Total } \\
\cline { 3 - 5 } & & ALPR & ALS II & ALMS & \\
\hline Banguelo (a) & $\mathbf{X}$ & $\mathbf{X}$ & $\mathbf{X}$ & $\mathbf{X}$ & $\mathbf{4}$ \\
Desdentado & $\mathbf{X}$ & $\mathbf{X}$ & & $\mathbf{X}$ & $\mathbf{3}$ \\
Sem dente & & $\mathbf{X}$ & & $\mathbf{X}$ & $\mathbf{2}$ \\
Boca murcha & & $\mathbf{X}$ & & $\mathbf{X}$ & $\mathbf{2}$ \\
Gengiva & $\mathbf{X}$ & & & & $\mathbf{1}$ \\
\multicolumn{1}{c}{ TOTAL } & $\mathbf{3}$ & $\mathbf{4}$ & $\mathbf{1}$ & $\mathbf{4}$ & \\
\hline
\end{tabular}

Sem dúvida a lexia banguela é bastante freqüente e tem distribuição regular em várias regiões do Brasil.

\section{Análise de traços semânticos}

A pesquisa em dicionários gerais de língua portuguesa teve como resultado as seguintes acepções:

- banguela 1 (Coloq) sem um ou mais dentes da frente; desdentado, S 2 (Coloq) pessoa sem um ou mais dentes; $\rightarrow$ na b. com o veículo em ponto morto $\&$ Do Top. Benguela, em Angola (África). Os benguelas, no passado, tinham o hábito de limar os incisivos (BORBA, 2004, p. 160).

- benguela 1 m.q. BENGUELA ('indivíduo, povo e acp adjetivas') 2 que ou quem se ressente da falta de um ou mais dentes na parte frontal de uma ou de ambas as arcadas, banguelo $¥$ f. menos us: benguela 3 que ou quem pronuncia mal as palavras, como se não possuísse dentes na parte frontal da arcada; que ou quem fala incorretamente, banguelo $¥ \mathrm{f}$. menos us: benguela $\rightarrow$ na $\mathrm{b}$. B infrm. em ponto morto, desengrenado. (diz-se de caixa de marcha de automóvel) (descer uma ladeira na b.) (C) ETIM top. Benguela (Angola), tomado como subst. Com a mesma orig. da f. divg. benguela; as acp. 2 e 3 ligam-se ao fato de os benguelas, na África, no passado, usarem limar os 
dentes incisivos $\&$ SIN/VAR banguelo, benguela, canhanha, caxinxa, desdentado (HOUAISS, 2001, p.396).

- Desdentado adj.sm. 1 que ou quem não possui alguns ou todos os dentes *adj. 2 relativo ao desdentado $¥$ f. menos us: edentado; ver dent- $\iota$ SIN/VAR como adj: agonfo, anodonte; como adj sm: ver sinonímia de banguela. $\varnothing$ ANT. dentado (HOUAISS, 2001, p.973).

- desdentado [De des- + dentado ${ }^{1}$.] Adjetivo. 1.Sem dentes. [Sin. (p. us.): edentado.] 2.Que deixa ver a falta de dentes: "seus cândidos olhos cor do céu, seu sorriso desdentado, e seu ar simples, ingênuo" (Malu de Ouro Preto, Siri na Noite de Lua, p. 13) (FERREIRA, dic. eletr.).

A origem etimológica de banguela, como vemos, explica a forma completamente diferente da lexia relativa a dente. Nesse ponto recaiu em erro nosso primeiro dialetólogo, Amaral (1920), ao supor que dos africanos herdáramos apenas a influência na fonética. A lexia banguela, originária do topônimo Benguela (Angola), é uma contribuição dos africanos para o nosso léxico.

As marcas 'coloquial' ou 'informal' apontam para uma variante de grande vitalidade em Iguape e, provavelmente, em muitas regiões do Brasil. Não encontramos questão sobre esse tema nos atlas consultados.

Pela lógica, a lexia desdentado, muito mais transparente por ser derivada de dente, deveria ser a mais difundida. De novo percebe-se a influência da cultura, da história de um povo, inscrita na língua. Note-se também que o povo flexiona a forma original terminada em -a, comum aos dois gêneros, criando o masculino banguelo.

Sobre a lexia banguelo, Cascudo (2004, p. 47) anota: pessoa sem dentes; sem os incisivos. 
Benguelo.

Acho ser coragem sua

Me convidar pra “martelo',

Que eu não respeito outro homem

Quanto mais um amarelo,

Que, além de amarelo, é torto,

E, além de torto, banguelo.

Leonardo Mota (Cantadores, Rio de Janeiro, 1921)

Cascudo (2004) completa a explicação:

O costume de limar os dentes, por motivos estéticos ou religiosos, é encontrado em diversos lugares. Letourneau e Topinard registram essa tradição na Austrália, onde as crianças tinham os incisivos arrancados e outros limados em ponta. $\mathrm{O}$ vocábulo interessa à etnografia brasileira por estar ligado a uma fonte exportadora de escravos em Angola. Os negros banguelas ou ganguelas, luimbas, loenas cortavam os dentes (...) ( p. 47).

\subsection{Nariz}

Analisaremos, a seguir, as questões 101 e 102, referentes a nariz.

Mais uma vez é Cascudo (1973) quem citamos para falar sobre a simbologia e os costumes associados ao nariz.

O nariz, órgão essencial da respiração (os orifícios têm em português o nome de ventas, ventana, por onde passa o vento), marca a fisionomia, dando-lhe a característica. La regione anatômica del naso è uma di quelle che più contribuiscono allá varietà dei tipi fisionomici _ escreve Biasutti. "Antes fanhoso do que sem nariz". Qui coupe son nez dègarnit son visage. Cortá-lo era castigo aos traidores e assim Afonso de Albuquerque usou e abusou em Ormuz (1507), Goa (1510) e Málaca (1511) e os espanhóis e portugueses divulgaram o processo nas terras americanas. Amputavam-no às adúlteras na Índia (Panchatantra, I, IV, Hitopadexa, II, VI) e mundo oriental. (p. 244-245)

Em outro trecho:

O nariz, ou as ventas, fossas nasais, é símbolo da vergonha e respeito: "dizer verdades nas ventas é desafio. 'Você não tem vergonha nessas ventas?' Meter o dedo na venta de alguém é desmentir, contrariar, opor negativa formal"(CASCUDO, 1973, p.245). 
Os ornamentos nasais são muito usados, atravessados no septo nasal ou nas asas, em várias partes do mundo, como nos conta Cascudo:

(...) são de ampla geografia funcional, Melanésia, Polinésia, África Equatorial, região dos lagos, austral, toda América. Era jóia privativa do imperador asteca. $\mathrm{Na}$ Índia contemporânea ainda resiste ornamento de ouro pendendo do tabique nasal. $\mathrm{O}$ nédzem, anel nasal, era egípcio e bíblico (CASCUDO, 1973, p. 245).

Por fim, há que se falar da importância do nariz, conjugado com a boca, no processo da respiração:

O nariz e a cavidade bucal aliam-se no processo respiratório. O sopro, hálito, bafo, é a essência da vida organizada, símbolo mais expressivo de sua presença vital. Alma, anima latina, anemos grega, significa o sopro. Soprar é um poderoso transmissor na técnica das feitiçarias urbanas e rurais e renomada terapêutica indígena universal. Não há tratamento entre povos "selvagens" sem o sopro, impondo a saúde e afastando a doença (CASCUDO, 1973, p.247).

\subsubsection{Fanhoso}

QUESTÃO 101 - ... a pessoa que parece falar pelo nariz? Imitar

\section{Freqüência e distribuição}

Tabela 57 - Freqüiência geral da questão 101- Iguape

\begin{tabular}{lrr}
\hline \multirow{2}{*}{ Lexia } & \multicolumn{2}{c}{ Freqüiência } \\
\cline { 2 - 3 } & \multicolumn{1}{c}{ VA } & \multicolumn{1}{c}{ VR (\%) } \\
\hline Fanhoso & 7 & 58,33 \\
Fanho & 5 & 41,67 \\
Total & $\mathbf{1 2}$ & $\mathbf{1 0 0 , 0 0}$ \\
\hline
\end{tabular}

Os dados da tabela acima indicam que os falantes/ouvintes de Iguape dão leve preferência à lexia fanhoso, pouca coisa mais atualizada que a forma fanho.

Tabela 58 - Freqüência da questão 101 por sexo/gênero

\begin{tabular}{lrrrrrr}
\hline \multirow{2}{*}{ Lexia } & \multicolumn{6}{c}{ Sexo/Gênero } \\
\cline { 2 - 7 } & \multicolumn{2}{c}{ Homens } & \multicolumn{2}{c}{ Mulheres } & \multicolumn{2}{c}{ Total } \\
\cline { 2 - 7 } & \multicolumn{1}{c}{ VA } & \multicolumn{1}{c}{ VR (\%) } & \multicolumn{1}{c}{ VA } & VR (\%) & \multicolumn{1}{c}{ VA } & \multicolumn{1}{c}{ VR (\%) } \\
\hline Fanhoso & 3 & 50,00 & 4 & 66,67 & 7 & 58,33 \\
Fanho & 3 & 50,00 & 2 & 33,33 & 5 & 41,67 \\
\multicolumn{1}{c}{ total } & $\mathbf{6}$ & $\mathbf{1 0 0 , 0 0}$ & $\mathbf{6}$ & $\mathbf{1 0 0 , 0 0}$ & $\mathbf{1 2}$ & $\mathbf{1 0 0 , 0 0}$ \\
\hline
\end{tabular}


Não há diferenças significativas na comparação entre os sexos/gêneros quanto ao uso das variantes fanho e fanhoso, apenas uma pequena predominância de atualização da lexia fanhoso por parte das mulheres.

Tabela 59 - Freqüência da questão 101 por faixa etária

\begin{tabular}{lrrrrrr}
\hline \multirow{2}{*}{ Lexia } & \multicolumn{5}{c}{ Faixa Etária } \\
\cline { 2 - 7 } & \multicolumn{2}{c}{$\mathbf{1 8}$ a 30 anos } & \multicolumn{2}{c}{ 66 anos ou mais } & \multicolumn{2}{c}{ Total } \\
\cline { 2 - 7 } & \multicolumn{1}{c}{ VA } & \multicolumn{1}{c}{ VR (\%) } & \multicolumn{1}{c}{ VA } & \multicolumn{1}{c}{ VR (\%) } & \multicolumn{1}{c}{ VA } & \multicolumn{1}{c}{ VR (\%) } \\
\hline Fanhoso & 1 & 16,67 & 6 & 100,00 & 7 & 58,33 \\
Fanho & 5 & 83,33 & 0 & 0,00 & 5 & 41,67 \\
$\quad$ Total & $\mathbf{6}$ & $\mathbf{1 0 0 , 0 0}$ & $\mathbf{6}$ & $\mathbf{1 0 0 , 0 0}$ & $\mathbf{1 2}$ & $\mathbf{1 0 0 , 0 0}$ \\
\hline
\end{tabular}

Nesta tabela percebe-se nitidamente que a segunda faixa etária dá preferência absoluta à forma fanhoso, e o contrário acontece com a forma fanho, que é opção amplamente utilizada na primeira faixa etária.

Tabela 60 - Distribuição das lexias da questão 101 pelos pontos

\begin{tabular}{|c|c|c|c|c|c|c|c|c|}
\hline \multirow{3}{*}{ Lexia } & \multicolumn{8}{|c|}{ Ponto } \\
\hline & \multicolumn{2}{|c|}{ Icapara } & \multicolumn{2}{|c|}{ Rocio } & \multicolumn{2}{|c|}{ Jairê } & \multicolumn{2}{|c|}{ Total } \\
\hline & VA & VR (\%) & VA & VR (\%) & VA & $\operatorname{VR}(\%)$ & VA & VR (\%) \\
\hline Fanhoso & 2 & 50,00 & 3 & 75,00 & 2 & 50,00 & 7 & 58,33 \\
\hline Fanho & 2 & 50,00 & 1 & 25,00 & 2 & 50,00 & 5 & 41,67 \\
\hline Total & 4 & 100,00 & 4 & 100,00 & 4 & 100,00 & 12 & 100,00 \\
\hline
\end{tabular}

No bairro do Rocio dá-se preferência à lexia fanhoso, enquanto nos outros dois bairros há equilíbrio entre as duas formas.

\section{Análise de traços semânticos}

- fanhoso [De fanha+-oso.] Adjetivo. 1.Que fala ou parece falar pelo nariz. [Sin.: fanha (bras.,S.,e prov. lus.).F.red.: fanho (bras.).] 2.Diz-se da voz de quem fala assim, ou de som que lembra essa voz.[Sin.ger.:roufenho, rouquenho.]Advérbio.3.Com voz fanhosa: falar fanhoso (FERREIRA, dic. eletr.). 
- Fanho adj. b m.q. fanhoso ('que parece falar pelo nariz’) (C) ETIM voc. tido como expressivo (HOUAISS, 2001, p.1306).

- Fanhoso adj 1 que parece falar pelo nariz ou como se estivesse com o nariz apertado. 2 diz-se da voz de quem fala dessa maneira (C) ETIM fanha+-oso (HOUAISS, 2001, p.1306).

- Fanha adj $2 \mathrm{~g}$ s $2 \mathrm{~g}$ B s. p diz-se de ou pessoa fanhosa (C) ETIM voc. tido como expressivo (HOUAISS, 2001, p.1306).

A rede sêmica do semema de fanho, comum a fanhoso, conjuga as duas lexias. Um dos traços sêmicos, 'que parece falar pelo nariz', é sema inerente de ambos. Aliás, parece que temos, na verdade, só uma forma: fanho, segundo Ferreira, é forma reduzida de fanhoso. O núcleo sêmico do semema de fanhoso/fanho remete à parte do corpo nariz e, como já aconteceu anteriormente com outras partes do corpo humano, temas das questões aqui analisadas, o enfoque é o desvio. A questão é formulada de modo a abordar uma anomalia ou defeito físico relativo ao nariz. Falar pelo nariz, ou como se o nariz estivesse apertado, não é o normal.

A origem etimológica da lexia indica que ela é tida como "vocábulo expressivo", o que não diz muito. Seu significado remete ao som da pessoa que fala assim, ou seja, E = C. O plano da expressão se identifica ao plano do conteúdo.

Para evitar nomear a dificuldade, prefere-se a perífrase lexical "que parece falar pelo nariz”. Um eufemismo, que é um dos modos de se contornar o tabu lingüístico.

O fanho ou fanhoso é um dos personagens mais explorados no anedotário popular. 


\subsubsection{Meleca/tatu}

QUESTÃO 102 - ... a sujeirinha dura que se tira do nariz com o dedo?

\section{Freqüência e distribuição}

Tabela 61 - Frequiência geral da questão 102- Iguape

\begin{tabular}{lrr}
\hline \multirow{2}{*}{ Lexia } & \multicolumn{2}{c}{ Freqüência } \\
\cline { 2 - 3 } & VA & \multicolumn{1}{c}{ VR (\%) } \\
\hline Tatu (do nariz) & 9 & 75,00 \\
Cera (do nariz) & 2 & 16,67 \\
Pelanca (do nariz) & 1 & 8,33 \\
$\quad$ Total & $\mathbf{1 2}$ & $\mathbf{1 0 0 , 0 0}$ \\
\hline
\end{tabular}

Em Iguape, é bastante alto o índice de atualização da lexia tatu (do nariz).

Tabela 62 - Freqüência da questão 102 por sexo/gênero

\begin{tabular}{|c|c|c|c|c|c|c|}
\hline \multirow{3}{*}{ Lexia } & \multicolumn{6}{|c|}{ Sexo/Gênero } \\
\hline & \multicolumn{2}{|c|}{ Homens } & \multicolumn{2}{|c|}{ Mulheres } & \multicolumn{2}{|c|}{ Total } \\
\hline & VA & VR (\%) & VA & VR (\%) & VA & VR (\%) \\
\hline Tatu (do nariz) & 5 & 83,33 & 4 & 66,67 & 9 & 75,00 \\
\hline Cera (do nariz) & 1 & 16,67 & 1 & 16,67 & 2 & 16,67 \\
\hline $\begin{array}{l}\text { Pelanca (do } \\
\text { nariz) }\end{array}$ & 0 & 0,00 & 1 & 16,67 & 1 & 8,33 \\
\hline Total & 6 & 100,00 & 6 & 100,00 & 12 & 100,00 \\
\hline
\end{tabular}

Homens e mulheres usam indistintamente a lexia tatu para nomear a sujeirinha que se tira do nariz.

\section{Tabela 63 - Frequiência da questão 102 por faixa etária}

\begin{tabular}{lrrrrrr}
\hline \multirow{2}{*}{ Lexia } & \multicolumn{6}{c}{ Faixa Etária } \\
\cline { 2 - 7 } & \multicolumn{2}{c}{$\mathbf{1 8}$ 30 anos } & \multicolumn{2}{c}{ 66 anos ou mais } & \multicolumn{2}{c}{ Total } \\
\cline { 2 - 8 } & VA & \multicolumn{1}{c}{ VR (\%) } & \multicolumn{1}{c}{ VA } & \multicolumn{1}{c}{ VR (\%) } & \multicolumn{1}{c}{ VA } & \multicolumn{1}{c}{ VR (\%) } \\
\hline Tatu (do nariz) & 5 & 83,33 & 4 & 66,67 & 9 & 75,00 \\
Cera (do nariz) & 1 & 16,67 & 1 & 16,67 & 2 & 16,67 \\
Pelanca (do & & & & & & \\
nariz) & 0 & 0,00 & 1 & 16,67 & 1 & 8,33 \\
\multicolumn{1}{c}{ Total } & $\mathbf{6}$ & $\mathbf{1 0 0 , 0 0}$ & $\mathbf{6}$ & $\mathbf{1 0 0 , 0 0}$ & $\mathbf{1 2}$ & $\mathbf{1 0 0 , 0 0}$ \\
\hline
\end{tabular}


Quanto à variável faixa etária, exatamente da mesma maneira que apontado na tabela anterior, a variante tatu é usada indistintamente entre jovens da primeira faixa e os mais idosos, da segunda faixa.

Tabela 64 - Distribuição das lexias da questão 102 pelos pontos

\begin{tabular}{lrrrrrrrr}
\hline \multirow{2}{*}{ Lexia } & \multicolumn{9}{c}{ Ponto } \\
\cline { 2 - 9 } & \multicolumn{2}{c}{ Icapara } & \multicolumn{1}{c}{ Rocio } & \multicolumn{2}{c}{ Jairê } & \multicolumn{2}{c}{ Total } \\
\cline { 2 - 10 } & \multicolumn{1}{c}{ VA } & \multicolumn{1}{c}{ VR (\%) } & \multicolumn{1}{c}{ VA } & VR (\%) & VA & \multicolumn{1}{c}{ VR (\%) } & \multicolumn{1}{c}{ VA } & \multicolumn{1}{c}{ VR (\%) } \\
\hline Tatu (do nariz) & 4 & 100,00 & 2 & 50,00 & 3 & 75,00 & 9 & 90,00 \\
Cera (do nariz) & 0 & 0,00 & 2 & 50,00 & 0 & 0,00 & & 0,00 \\
Pelanca (do nariz) & 0 & 0,00 & 0 & 0,00 & 1 & 25,00 & 1 & 10,00 \\
TOTAL & $\mathbf{4}$ & $\mathbf{1 0 0 , 0 0}$ & $\mathbf{4}$ & $\mathbf{1 0 0 , 0 0}$ & $\mathbf{4}$ & $\mathbf{1 0 0 , 0 0}$ & $\mathbf{1 0}$ & $\mathbf{1 0 0 , 0 0}$ \\
\hline
\end{tabular}

Em Icapara é massivo o uso da variante lexical tatu (do nariz). No Rocio, a variante estudada divide a preferência do falante/ouvinte com a forma cera (do nariz). E no Jairê, a preferência é pela realização da lexia tatu (do nariz).

Tabela 65 - Comparação da variação lexical da questão 102: Iguape - Outros atlas regionais

\begin{tabular}{|c|c|c|c|c|}
\hline \multirow{2}{*}{ Lexia } & \multirow{2}{*}{ Município de Iguape } & \multicolumn{2}{|c|}{ Atlas } & \multirow{2}{*}{ Total } \\
\hline & & Alse II & Alms & \\
\hline Tatu (do nariz) & $\mathbf{X}$ & & $\mathbf{X}$ & 2 \\
\hline Cera (do nariz) & $\mathbf{X}$ & & $\mathbf{X}$ & 2 \\
\hline Pelanca (do nariz) & $\mathbf{X}$ & & & 1 \\
\hline Catarro & & & $\mathbf{X}$ & 1 \\
\hline Sujeira & & & $\mathbf{X}$ & 1 \\
\hline Cateto & & & $\mathbf{X}$ & 1 \\
\hline Meleca & & & $\mathbf{X}$ & 1 \\
\hline Caca & & & $\mathbf{X}$ & 1 \\
\hline Cacaca & & & $\mathbf{X}$ & 1 \\
\hline Cacaraca & & $\mathbf{X}$ & & 1 \\
\hline Cacareca & & $\mathbf{X}$ & & 1 \\
\hline Caraca & & $\mathbf{X}$ & & 1 \\
\hline Careca & & $\mathbf{X}$ & & 1 \\
\hline Carne seca & & & $\mathbf{X}$ & 1 \\
\hline Quereca & & $\mathbf{X}$ & & 1 \\
\hline Ranho & & & $\mathbf{X}$ & 1 \\
\hline Catoto & & & $\mathbf{X}$ & 1 \\
\hline Total & 3 & 5 & 11 & \\
\hline
\end{tabular}


Como podemos notar, há grande variação quanto à designação para a 'sujeirinha dura que se tira do nariz com o dedo'. As duas lexias de maior incidência, tatu (do nariz) e cera (do nariz), aparecem em Iguape e no Mato Grosso do Sul.

\section{Análise de traços semânticos}

Para a análise dos aspectos semântico-lexicais das variantes encontradas, consultamos os dicionários gerais de língua portuguesa.

- Tatu sm. 11 infrm. ranho seco (HOUAISS, 2001, p. 2678).

- Tatu [Do tupi.] Substantivo masculino. 1.Bras. Zool. Designação comum aos mamíferos desdentados, dasipodídeos, com seis gêneros no Brasil e aproximadamente 11 espécies. Noctívagos, alimentam-se de raízes, frutos, insetos, e até de carniça. Os tatus reproduzem-se por poliembrionia, e todos os indivíduos de um mesmo parto têm o mesmo sexo (FERREIRA, dic. eletr.).

- Ranho [Der. regress. de ranhoso, alter. de ronhoso, de ronha.] Substantivo masculino. 1. Pleb. V. тисо: "Escondido perto do tanque, ficou chorando baixinho e engolindo o ranho que lhe descia do nariz." (Macedo Miranda, Pequeno Mundo Outrora, p. 42.) (FERREIRA, dic. eletr.).

- Tatu sm. 1 mamífero desdentado, que mora em toca escavada no chão, de hábitos noturnos, corpo coberto por uma carapaça formada por faixas de pequenas placas ósseas, cauda fina e comprida; (...) (BORBA, 2004, p.1339).

- Cera sf substância amarelada e mole, produzida pelas abelhas, com que se fazem os favos; 2 substância vegetal com essas características: cera de carnaúba (...) 4 secreção do conduto auditivo externo; cerume (...) (BORBA, 2004, p. 264).

- Meleca [De mel ${ }^{1}+$-eca.] Substantivo feminino. 1. Bras. Pop. Secreção nasal ressequida. [Sin.: (bras. N.E.): catota e (lus.) caco e monca.] (FERREIRA, dic. eletr.). 
A lexia tatu (do nariz) que encontramos em nossa pesquisa em Iguape, já aparece no dicionário Houaiss (2001) como uma das acepções do verbete tatu, o mamífero desdentado, que chamaremos de $t a t u{ }^{1}$. Ou seja, já está lexicalizada a acepção de tatu como 'sujeirinha dura que se tira do nariz com o dedo', que vamos identificar como $t a t u^{2}$. O semema de $t a t u^{2}$ reúne os semas 'ranho seco' e 'secreção nasal ressequida'. Isso nos faz pensar que, por inferência, o sema inerente 'que mora em toca escavada no chão', de tatu', tenha se associado aos semas citados, resultando num semema novo, ampliado desses semas subjacentes: 'muco ou secreção que se forma dentro das fossas nasais' de tatu².

Por analogia, ou por inferência, semas aferentes atualizam-se, relacionando 'ranho seco' a tatu', porque assim como ele, o tatu' 'mora em toca escavada (...)'. O sema inerente 'corpo coberto por uma carapaça formada (...) placas ósseas', pela realização dinâmica do discurso, atualiza o sema aferente 'duro'. Raciocinando por analogia, temos: o tatu está para 'toca escavada no chão', assim como o 'ranho seco' está para as fossas nasais. Ou: 'ranho seco': nariz :: tatu': toca; ou, tatu ${ }^{1}:$ toca $:: \operatorname{tatu}^{2}$ : nariz. Os semas aferentes que se apreendem, portanto, são 'escondido em buraco', 'difícil de buscar'e 'duro’.

Procurando uma explicação para a denominação da 'sujeirinha dura que se tira do nariz com o dedo', em Iguape, lembramos que Rohlfs (1979), pesquisador do léxico românico, já identificara esse processo de comparação metafórica das línguas românicas com animais, fator de grande produtividade.

Tatu tem origem etimológica na língua tupi, como assinala Ferreira (dic. eletr.). A explicação do que aconteceu em Iguape deve ser a mesma de Mato Grosso do Sul, onde a variante $t a t u^{2}$ também ocorre: as condições do espaço geográfico devem ter sido determinantes para a associação das formas. Iguape foi fundada à época do Descobrimento do Brasil e ocupa a faixa do litoral ao longo da qual se distribuíam os 
índios da costa - genericamente chamados tupis. O contato entre os colonizadores portugueses e os índios deixou marcas indeléveis no léxico da língua portuguesa falada no Brasil. Não podemos deixar de mencionar a relação estreita entre o homem americano e a natureza brasileira, a Mata Atlântica, em Iguape, refletida nos inúmeros topônimos, de todos os tipos, e nas metáforas, como é este caso. Os índios, primeiros habitantes do Brasil, deram o primeiro nome a tudo: fauna, flora, acidentes geográficos e tudo o mais.

A lexia cera, que também aparece em Iguape, deve ter sido produzida por ativação de um de seus semas, por uma atualização seletiva, que fez emergir 'secreção do conduto auditivo externo; cerume'. Isto é, por analogia a 'cera do ouvido', 'cerume'.

Fomos procurar em Ferreira (dic. eletr.) a remissiva de ranho, [Der. regress. de ranhoso, alter. de ronhoso, de ronha.] mas não encontramos uma ligação clara entre as lexias.

ronha- [Do lat. vulg. *ronea, alter. de aranea.] Substantivo feminino. 1.Sarna que ataca ovelhas e cavalos. 2.P. ext. Doença de plantas. 3.Pop. Malícia, manha, astúcia, solércia: "Onde pensavas que existia amabilidade, havia ronha e muita!" (Coelho Neto, $A$ Conquista, p. 195). 


\subsection{Pescoço}

Esta parte do corpo humano é a ligação entre a cabeça e as demais partes do corpo humano, tronco e membros. É a última das subdivisões da subárea cabeça.

\subsubsection{Soluço}

QUESTÃO 103 - ... este barulhinho que se faz? Soluçar.

\section{Freqüiência e distribuição}

Tabela 66 - Freqüência geral da questão 103- Iguape

\begin{tabular}{lrr}
\hline \multirow{2}{*}{ Lexia } & \multicolumn{2}{c}{ Freqüência } \\
\cline { 2 - 3 } & \multicolumn{1}{c}{ VA } & \multicolumn{1}{c}{ VR (\%) } \\
\hline Soluço & 9 & 75,00 \\
Jojoca & 3 & 25,00 \\
Total & $\mathbf{1 2}$ & $\mathbf{1 0 0 , 0 0}$ \\
\hline
\end{tabular}

Ao lado da lexia soluço, em Iguape usa-se também a variante jojoca, item lexical de base indígena.

Tabela 67 - Freqüência da questão 103 por sexo/gênero

\begin{tabular}{crrrrrr}
\hline \multirow{3}{*}{ Lexia } & \multicolumn{6}{c}{ Sexo/Gênero } \\
\cline { 2 - 7 } & \multicolumn{2}{c}{ Homens } & \multicolumn{2}{c}{ Mulheres } & \multicolumn{2}{c}{ Total } \\
\cline { 2 - 7 } & \multicolumn{1}{c}{ VA } & \multicolumn{1}{c}{ VR (\%) } & \multicolumn{1}{c}{ VA } & \multicolumn{1}{c}{ VR (\%) } & \multicolumn{1}{c}{ VA } & \multicolumn{1}{c}{ VR (\%) } \\
\hline Soluço & 6 & 100,00 & 3 & 50,00 & 9 & 75,00 \\
Jojoca & 0 & 0,00 & 3 & 50,00 & 3 & 25,00 \\
Total & $\mathbf{6}$ & $\mathbf{1 0 0 , 0 0}$ & $\mathbf{6}$ & $\mathbf{1 0 0 , 0 0}$ & $\mathbf{1 2}$ & $\mathbf{1 0 0 , 0 0}$ \\
\hline
\end{tabular}

Constatamos absoluta preferência em relação ao uso da lexia soluço por parte dos homens, enquanto as mulheres estão divididas igualmente entre a lexia jojoca e soluço. 
Tabela 68 - Freqüiência da questão 103 por faixa etária

\begin{tabular}{lrrrrrr}
\hline \multirow{3}{*}{ Lexia } & \multicolumn{5}{c}{ Faixa Etária } \\
\cline { 2 - 7 } & \multicolumn{2}{c}{$\mathbf{1 8}$ a 30 anos } & \multicolumn{2}{c}{ 66 anos ou mais } & \multicolumn{2}{c}{ Total } \\
\cline { 2 - 7 } & \multicolumn{1}{c}{ VA } & \multicolumn{1}{c}{ VR (\%) } & \multicolumn{1}{c}{ VA } & VR (\%) & \multicolumn{1}{c}{ VA } & \multicolumn{1}{c}{ VR (\%) } \\
\hline Soluço & 6 & 100,00 & 3 & 50,00 & 9 & 75,00 \\
Jojoca & 0 & 0,00 & 3 & 50,00 & 3 & 25,00 \\
$\quad$ Total & $\mathbf{6}$ & $\mathbf{1 0 0 , 0 0}$ & $\mathbf{6}$ & $\mathbf{1 0 0 , 0 0}$ & $\mathbf{1 2}$ & $\mathbf{1 0 0 , 0 0}$ \\
\hline
\end{tabular}

Como era de se esperar, os jovens da primeira faixa etária têm preferência total pela lexia soluço. Os sujeitos da segunda faixa etária, no entanto, estão divididos entre as variantes soluço e jojoca.

Tabela 69 - Distribuição das lexias da questão 103 pelos pontos

\begin{tabular}{lrrrrrrrr}
\hline \multirow{2}{*}{ Lexia } & \multicolumn{9}{c}{ Ponto } \\
\cline { 2 - 9 } & \multicolumn{2}{c}{ Icapara } & \multicolumn{2}{c}{ Rocio } & \multicolumn{2}{c}{ Jairê } & \multicolumn{2}{c}{ Total } \\
\cline { 2 - 9 } & \multicolumn{1}{c}{ VA } & \multicolumn{1}{c}{ VR (\%) } & \multicolumn{1}{c}{ VA } & \multicolumn{1}{c}{ VR (\%) } & \multicolumn{1}{c}{ VA } & \multicolumn{1}{c}{ VR (\%) } & \multicolumn{1}{c}{ VA } & \multicolumn{1}{c}{ VR (\%) } \\
\hline Soluço & 2 & 50,00 & 4 & 100,00 & 3 & 75,00 & 9 & 75,00 \\
Jojoca & 2 & 50,00 & 0 & 0,00 & 1 & 25,00 & 3 & 25,00 \\
Total & $\mathbf{4}$ & $\mathbf{1 0 0 , 0 0}$ & $\mathbf{4}$ & $\mathbf{1 0 0 , 0 0}$ & $\mathbf{4}$ & $\mathbf{1 0 0 , 0 0}$ & $\mathbf{1 2}$ & $\mathbf{1 0 0 , 0 0}$ \\
\hline
\end{tabular}

Rocio, Jairê e Icapara mostram preferência, nessa ordem, decrescente, pela forma soluço, enquanto que, em ordem inversa crescente, a segunda opção é jojoca.

Tabela 70 - Comparação da variação lexical da questão 103: Iguape - Outros atlas regionais

\begin{tabular}{lcccc}
\hline \multirow{2}{*}{ Lexia } & \multirow{2}{*}{ Município de Iguape } & \multicolumn{2}{c}{ Atlas } & \multirow{2}{*}{ Total } \\
\cline { 3 - 4 } & $\mathbf{X L P R}$ & ALS II & \\
\hline Soluço & $\mathbf{X}$ & $\mathbf{X}$ & $\mathbf{X}$ & $\mathbf{3}$ \\
Jojoca & & $\mathbf{X}$ & $\mathbf{2}$ & $\mathbf{2}$ \\
\multicolumn{1}{l}{\begin{tabular}{l} 
Saluço \\
\multicolumn{1}{c}{ Total }
\end{tabular}} & $\mathbf{2}$ & $\mathbf{2}$ & $\mathbf{2}$ & $\mathbf{1}$ \\
\hline
\end{tabular}

A lexia soluço aparece atualizada em várias regiões brasileiras, e assim como em Iguape, é selecionada e usada pela maioria dos falantes/ouvintes. 


\section{Análise de traços semânticos}

Além dos dicionários gerais de língua portuguesa, para a análise desta questão, especificamente, consultamos o dicionário especializado de Drumond (1953):

- Soluço s.m. 2 FISIOL fenômeno reflexo que se manifesta por contração espasmódica e involuntária do diafragma, seguido de movimentos de distensão e de relaxamento, pelo qual o pouco de ar que a contração forçara a entrar no peito é expulso com ruído característico [Ocorre às vezes após a ingestão de líquiido ou de sólido] (a mãe estava aflita com os s. do bebê) (C ETIM lat. vulg. sugglutium < lat. cl. singultus,us 'soluço, suspiro', sob infl. de subgluctire 'engolir com dificuldade'; f. hist. s XIV soluço, s XV soluços (HOUAISS, 2001, p. 2604).

- Soluço Aspiração espasmódica de ar para os pulmões, que termina com um som característico devido à oclusão brusca das cordas vocais. O soluço é provocado por irritação dos nervos do diafragma, com produção de contracções rápidas deste músculo. A maior parte dos casos, em especial aqueles em que o soluço se repete habitualmente à mesma hora do dia, devem-se à indigestão (COUTINHO, 1977, p. 2130).

- Saluçar como de frio - Xejejoc (DRUMOND, p.112).

- Saluço assi - Jejoca (DRUMOND, p.112).

Encontramos em Diegues (2005, p. 183) a variante lexical jororoca, substantivo masculino, assim definido: "soluço, jojoca. Prenúncio de morte, suspiro final. Ex.: "O coitado não escapa desta noite, já está com a jororoca”.

O semema de soluço, termo técnico-científico da fisiologia e, por isso mesmo monossemêmico, apresenta os semas específicos 'contração espasmódica' e 'contracções rápidas' do diafragma, nos dois dicionários de língua geral, e semas que remetem ao barulho típico, inconfundível, do soluçar: 'ruído característico' e ‘som característico'. Para fazer a 
pergunta ao falante/ouvinte, bastava que fizéssemos a mímica, aliando movimentos repetidos e som hic...hic, para que ele identificasse o fenômeno e respondesse: jojoca, soluço. Ou soluço, jojoca. Freqüentemente, nesta questão, ao lado da lexia soluço, obtivemos uma segunda resposta, jojoca. Ou vice-versa.

Jojoca é uma lexia de base tupi - e aqui usamos a nomenclatura adotada por Aguilera (2007, p. 99-125), assim como a justificativa da autora de que é a denominação constante dos dicionários da Língua Portuguesa mais conhecidos no Brasil. Assim como no Paraná, cuja presença de tupinismos está ligada diretamente à ocupação do litoral nos séculos iniciais da colonização, também em Iguape temos as mesmas condições geográficas e histórico-sociais. Sem falar da proximidade das duas regiões, o que permite supor que muitas das lexias encontradas em Iguape componham com as do litoral paranaense uma mesma isoglossa.

Outro fator apontado também por Aguilera no ALPR, aplica-se a Iguape:

(...), temos um segundo grupo com nove lexias tupis (e variantes fônicas) que conseguiram ampliar o seu raio de ação: saindo do litoral, chegaram ao Planalto de Curitiba e acompanharam o homem na sua caminhada, primeiramente rumo ao $2^{\circ}$ Planalto e logo após seguindo a rota dos tropeiros, já no final do século XVIII e início do XIX. São elas boitatá/baetatá/baitatá; caburé; curica; guamirim; incõel inconha; jojoca/jejoca; peca/pequinha/guapeca/guapequinha; pinhé e urupê.

Ficamos surpresos e ao mesmo tempo satisfeitos por encontrar, ainda, em Iguape, resquícios da língua geral ou brasílica falada no Brasil no início da colonização, uma língua de intercurso, como apontara Amaral (1920) e Elia (1954), conforme citação abaixo, entre outros:

A respeito da difusão da língua geral, já observava Teodoro Sampaio:

Ao europeu, porém, ou aos seus descendentes cruzados, que realizaram as conquistas dos sertões, é que se deve a maior expansão do tupi, como língua geral, dentro das raias atuais do Brasil. As levas, que partiam do litoral, a fazerem descobrimentos, falavam, no geral, o tupi; pelo tupi designavam os novos descobrimentos, os rios, as montanhas, o próprios povoados que fundavam e que eram outras tantas colônias, espalhadas nos sertões, falando também o tupi e encarregando-se naturalmente de difundi-lo.

O português era, sim, a língua oficial, como ainda hoje o espanhol no Paraguai; a língua do comércio nos portos do litoral, nas cidades e vilas de mais importância e no seio das famílias, propriamente portuguesas; mas, ainda aí, aparecia o tupi, falado pelos fâmulos, quase todos índios ou de descendência índia (apud ELIA, p. 188). 
Também ficamos surpresos com a resistência dessa lexia, jojoca, que chegou até nós depois de mais de três séculos de transmissão oral, de geração em geração, constituindo-se em verdadeiro patrimônio cultural brasileiro e americano. Isso mostra que itens lexicais de base indígena foram preservados por comunidades caiçaras como as de Icapara, por exemplo.

\subsubsection{Nuca}

QUESTÃO $104-\ldots$ isto? Apontar.

A análise da frequiência e distribuição da questão 104, em Iguape, apontou a unanimidade de uso da lexia nuca pelos iguapenses. Foi a única lexia, dentre as questões selecionadas para esta pesquisa, que não apresentou variação. Vamos passar, em vista desse resultado, para a análise qualitativa de aspectos semântico-lexicais.

\section{Análise de traços semânticos}

Consultamos o dicionário de medicina de Coutinho (1977) o dicionário de Houaiss (2001) e o de mitologia, de Grimal (2005):

- Nuca [lat. nucha] _ região posterior e superior do pescoço (COUTINHO, p. 1610).

- Nuca s.f. ANAT região ínfero-posterior da cabeça que corresponde à vértebra cervical denominada atlas (C) ETIM lat. medv. nucha 'medula espinhal'< ar. nuhã; nesta acp. o t. foi introduzido no lat. medv. pelos técnicos italianos da Escola de Salermo liderados por Constantino de Cartago no s XI, no s XIII, o mantuano Mateo Silvático introduziu outro t. técnico no lat. medv. nucra(ti) 'nuca'<ar. nugra 'id'; ao saírem do âmbito de uso dos técnicos e se difundirem por meio de curandeiros e práticos veterinários na língua comum, os dois t. foram fruto de uma confusão, ao cabo da qual, nuca se deslocou do seu significado original para o de 
nucra, caindo este em desuso. $¥$ SIN/VAR cubata; ver tb sinonímia de cogote (HOUAISS, p. 2033).

- Cogote s.m. parte posterior da cabeça, nuca, cachaço (C ETIM esp. cogote (1490) 'parte superior e posterior do pescoço'; 'penacho que se colocava na parte posterior do capacete que protege o cogote’, prov. der. de coca ‘cabeça’ ¥ SIN/VAR atuá, cachaço, cangote, cocota, congote, gogote, nuca, quecote, quetote (HOUAISS, p.754).

- Atlas s.m. 2n. 3 ANAT a primeira vértebra cervical, que se articula com a região occipital do crânio e o sustenta (HOUAISS, p. 335).

- Atlant(o)- el. comp. antepositivo do gr. atlas,antos, alat. atlas,antis, deus da teogonia primitiva dos gregos, que sustentava as colunas do céu e detinha o oceano, dito por isso Atlântico; além dessa antiga conexão com esse oceano, aparente em vários der., há em osteologia e em biociências o seu emprego, já em f. greco-latinas primitivas, já em neologias do s XIX em diante (HOUAISS, p. 335).

No dicionário de mitologia citado encontramos a seguinte história, que interpreta os fatos do mundo e se reflete no léxico:

\begin{abstract}
Atlas. Gigante, filho de Jápeto e da Oceânide Clímene (por vezes, da Oceânide Ásia), é irmão de Menécio, Prometeu e Epimeteu, os "homens violentos". Certas tradições dão-no como filho de Urano e, por conseguinte, irmão de Crono. Atlas pertence à geração divina anterior à dos Olímpicos, a dos seres monstruosos e desproporcionados. Participou na luta dos Gigantes e dos Deuses e a punição que Zeus lhe infligiu consistiu em sustentar sobre os seus ombros a abóbada celeste. Situam geralmente a sua morada no Extremo Ocidente, no país das Hespérides. Por vezes, também o colocam "entre os Hiperbóreos". Heródoto é o primeiro a falar de Atlas como sendo uma montanha situada no norte de África. Terá sido Perseu quem, após matar a Górgona, transformara Atlas em rochedo, ao apresentar-lhe a cabeça de Medusa. Atribuem-se-lhe vários filhos: de Plêione, teve as Plêiades e as Híades; de Hespéride, as Hespérides. Díone também é considerada sua filha. Como filhos teve Hias e Héspero. As especulações tardias consideram Atlas como um astrónomo que ensinou aos homens as leis do céu e que, por essa razão, foi divinizado. Por vezes, distinguem-se três Atlas: o da África, um Atlas italiano e um Atlas da Arcádia, pai de Maia e, por conseguinte, avô de Hermes. Em relação a Atlas, epónimo de Atlântida, ver este nome. (GRIMAL,2005, p. 55)
\end{abstract}

A lexia nиса, de acordo com os semas que compõem seu semema, articula-se com o crânio e o sustenta. Na mitologia grega, a nuca é representada simbolicamente pelo gigante Atlas, que sustenta em seu ombro a abóbada celeste, ou seja, o crânio, a cabeça. 
Dessas metáforas infere-se a força e importância da nuca e o peso e a grandeza da cabeça, em sentido figurado. E o seu incomensurável limite, dado pelo adjetivo à abóbada: 'celeste'. A nuca é a ligação entre a cabeça e as outras partes do corpo: tronco e membros.

A lexia nиса, assim como seu referente, é bastante resistente. Em Iguape, como vimos, a lexia não concorre com outra variante, é norma semântico-lexical incontestável. Em outras regiões, de acordo com as indicações constantes do dicionário Houaiss (2001), aparecem outras variantes lexicais.

\subsubsection{Pomo-de-adão/gogó}

QUESTÃO 105 - ... esta parte alta do pescoço do homem? Apontar.

\section{Freqüiência e distribuição}

A tabela a seguir reúne as respostas à questão ${ }^{\circ} 105$, colhidas em Iguape:

\section{Tabela 71 - Freqüência geral da questão 105- Iguape}

\begin{tabular}{lrr}
\hline \multirow{2}{*}{\multicolumn{1}{c}{ Lexia }} & \multicolumn{2}{c}{ Freqüiência } \\
\cline { 2 - 3 } & \multicolumn{1}{c}{ VA } & \multicolumn{1}{c}{ VR (\%) } \\
\hline Gogó & 4 & 33,33 \\
Gago & 1 & 8,33 \\
Garganta & 1 & 8,33 \\
Pomo-de-Adão & 1 & 8,33 \\
Fruta do pecado & 1 & 8,33 \\
Abstenções & 4 & 33,33 \\
$\quad$ TOTAL & $\mathbf{1 2}$ & $\mathbf{1 0 0 , 0 0}$ \\
\hline
\end{tabular}

A lexia usada para designar a parte mais alta no pescoço dos homens, em Iguape é, sem dúvida, gogó, só com desempenho comparável às abstenções.

Entre sujeitos do gênero feminino, é alta a frequiência, tanto absoluta quanto relativa, de uso do termo gogó. Vejamos os números: 
Tabela 72 - Frequiência da questão 105 por sexo/gênero

\begin{tabular}{|c|c|c|c|c|c|c|}
\hline \multirow{3}{*}{ Lexia } & \multicolumn{6}{|c|}{ Sexo/Gênero } \\
\hline & \multicolumn{2}{|c|}{ Homens } & \multicolumn{2}{|c|}{ Mulheres } & \multicolumn{2}{|c|}{ Total } \\
\hline & VA & VR (\%) & VA & VR (\%) & VA & VR (\%) \\
\hline Gogó & 3 & 50,00 & 1 & 16,67 & 4 & 33,33 \\
\hline Gago & 1 & 16,67 & 0 & 0,00 & 1 & 8,33 \\
\hline Garganta & 1 & 16,67 & 0 & 0,00 & 1 & 8,33 \\
\hline Pomo-de-Adão & 0 & 0,00 & 1 & 16,67 & 1 & 8,33 \\
\hline Fruta do pecado & 0 & 0,00 & 1 & 16,67 & 1 & 8,33 \\
\hline Abstenções & 1 & 16,67 & 3 & 50,00 & 4 & 33,33 \\
\hline Total & 6 & 100,00 & 6 & 100,00 & 12 & 100,00 \\
\hline
\end{tabular}

A grande maioria dos homens selecionou a lexia gogó para designar essa parte de seu corpo. Já as mulheres, em sua grande maioria, abstiveram-se de nomear essa parte da anatomia masculina.

Na tabela abaixo, podemos verificar o uso por faixa etária.

Tabela 73 - Frequiência da questão 105 por faixa etária

\begin{tabular}{lrrrrrr}
\hline \multirow{2}{*}{ Lexia } & \multicolumn{6}{c}{ Faixa Etária } \\
\cline { 2 - 7 } & \multicolumn{2}{c}{$\mathbf{1 8}$ a 30 anos } & \multicolumn{6}{c}{ 66 anos ou mais } & \multicolumn{2}{c}{ Total } \\
\cline { 2 - 7 } & VA & \multicolumn{1}{c}{ VR (\%) } & \multicolumn{1}{c}{ VA } & VR (\%) & VA & \multicolumn{1}{c}{ VR (\%) } \\
\hline Gogó & 3 & 50,00 & 1 & 16,67 & 4 & 33,33 \\
Gago & 0 & 0,00 & 1 & 16,67 & 1 & 8,33 \\
Garganta & 0 & 0,00 & 1 & 16,67 & 1 & 8,33 \\
Pomo-de-Adão & 1 & 16,67 & 0 & 0,00 & 1 & 8,33 \\
Fruta do & & & & & & \\
pecado & 0 & 0,00 & 1 & 16,67 & 1 & 8,33 \\
Abstenções & 2 & 33,33 & 2 & 33,33 & 4 & 33,33 \\
$\quad$ Total & $\mathbf{6}$ & $\mathbf{1 0 0 , 0 0}$ & $\mathbf{6}$ & $\mathbf{1 0 0 , 0 0}$ & $\mathbf{1 2}$ & $\mathbf{1 0 0 , 0 0}$ \\
\hline \multicolumn{1}{c}{} & & & & & &
\end{tabular}

Foram os jovens, os sujeitos da primeira faixa etária, que deram preferência ao uso de gogó. As respostas dos sujeitos de 66 anos em diante dividiram-se entre quatro outras lexias e a maior parte não respondeu.

Vejamos agora como se distribui a lexia estudada nos pontos selecionados. 
Tabela 74 - Distribuição das lexias da questão 105 pelos pontos

\begin{tabular}{lrrrrrrrr}
\hline \multirow{2}{*}{ Lexia } & \multicolumn{1}{c}{ Ponto } \\
\cline { 2 - 9 } & \multicolumn{2}{c}{ Icapara } & \multicolumn{1}{c}{ Rocio } & \multicolumn{2}{c}{ Jairê } & \multicolumn{2}{c}{ Total } \\
\cline { 2 - 9 } & VA & \multicolumn{1}{c}{ VR (\%) } & \multicolumn{1}{c}{ VA } & \multicolumn{1}{c}{ VR (\%) } & \multicolumn{1}{c}{ VA } & \multicolumn{1}{c}{ VR (\%) } & VA & VR (\%) \\
\hline Gogó & 2 & 50,00 & 1 & 25,00 & 1 & 25,00 & 4 & 33,33 \\
Gago & 0 & 0,00 & 0 & 0,00 & 1 & 25,00 & 1 & 8,33 \\
Garganta & 0 & 0,00 & 1 & 25,00 & 0 & 0,00 & 1 & 8,33 \\
Pomo-de-adão & 0 & 0,00 & 0 & 0,00 & 1 & 25,00 & 1 & 8,33 \\
Fruta-do-pecado & 0 & 0,00 & 0 & 0,00 & 1 & 25,00 & 1 & 8,33 \\
Abstenções & 2 & 50,00 & 2 & 50,00 & 0 & 0,00 & 4 & 33,33 \\
$\quad$ Total & $\mathbf{4}$ & $\mathbf{1 0 0 , 0 0}$ & $\mathbf{4}$ & $\mathbf{1 0 0 , 0 0}$ & $\mathbf{4}$ & $\mathbf{1 0 0 , 0 0}$ & $\mathbf{1 2}$ & $\mathbf{1 0 0 , 0 0}$ \\
\hline
\end{tabular}

Em Icapara é que encontramos o maior índice de emprego da lexia gogó e também o de abstenções. O Rocio apresenta $50 \%$ de índice de abstenção. O Jairê não apresenta abstenções: as respostas dos falantes/ouvintes estão divididas igualmente entre quatro lexias gogó, gago, pomo-de-adão e fruta do pecado.

\section{Análise de traços semânticos}

Consultando a definição e as remissivas de gogó e pomo-de-adão nos dicionários gerais de língua portuguesa, e no de medicina de Coutinho (1977), encontramos:

- gogó [alteração de goela] s.m. brasileirismo familiar 1 v. pomo-de-adão (FERREIRA, dic. eletr.).

- pomo-de-adão (remissiva de gogó) s.m. A saliência da cartilagem tireóide. [Tb. Se diz apenas adão; sin. nó-de-adão, nó da garganta, nó da goela, gogó. Pl. pomos-deadão.] (FERREIRA, dic. eletr.).

- pomo-de-adão s.m. ANAT ver proeminência laríngea * tb se diz apenas adão $($ ) ETIM os nomes populares pomo-de-adão e maçã-de-adão, para a acp. de ANAT 'parte superior da cartilagem tireóidea, mais acentuada nos homens', são alusões à lenda, citada por Nascentes, segundo a qual Adão se engasgou com um pedaço de maçã que ficou preso em sua garganta; ver ETIM de pomo (HOUAISS, 2001, p. 2256). 
- gogó s.m. regionalismo: Brasil 1 mesmo que pomo-de-adão 2 proposta ou promessa que não se tem intenção de cumprir 3 indivíduo arrotador, alardeador (HOUAISS, 2001, p. 1462).

- gogó go-gó (Or duv) Sm (Coloq) [Co] 1 saliência da cartilagem tireóide, no pescoço; pomo-de-adão: (ex.) 2 pescoço: (ex.) 3 órgão produtor da voz; garganta: (ex.) 4 fala envolvente; lábia (BORBA, 2004, p.682).

- maçã-de-adão (sin.: nó-de-adão) - Nome com que vulgarmente se conhece uma saliência mediana da região anterior do pescoço, que não é mais do que uma parte da cartilagem tiróide. É mais pronunciada no homem do que na mulher (COUTINHO, p.1410).

Recolhemos todas essas informações a respeito das lexias gogó e pomo-de-adão para chegar, em seguida, à explicação da forma "fruta do pecado", não lexicalizada nos dicionários.

Pelo inventário dos semas, vemos que as lexias pomo-de-adão, maçã-de-adão e nó-deadão têm os mesmos traços semânticos. São, portanto, parassinônimas. Elas são lexias compostas, cujo segundo elemento - adão - remete ao personagem da histórica bíblica, Adão. Em A Bíblia Vida Nova (1990, p.8-9), lemos no Gênesis:

Gênesis 2

"15 Tomou, pois, o SENHOR Deus ao homem e o colocou no jardim do Éden para o cultivar e o guardar. $16 \mathrm{E}$ lhe deu esta ordem: De toda árvore do jardim comerás livremente, 17 mas, da árvore do conhecimento do bem e do mal não comerás; porque no dia em que dela comeres, certamente morrerás. (...)

\section{Gênesis 3}

Mas a serpente, mais sagaz que todos os animais selváticos que o SENHOR Deus tinha feito, disse à mulher: É assim que Deus disse: Não comereis de toda árvore do jardim? 2 Respondeu-lhe a mulher: Do fruto das árvores do jardim podemos comer, 3 mas do fruto da árvore que está no meio do jardim, disse Deus: Dele não comereis, nem tocareis nele, para que não morrais. 4 Então a serpente disse à mulher: É certo que não morrereis. 5 Por que deus sabe que no dia em que dele comerdes se vos abrirão os olhos e, como Deus, sereis conhecedores do bem e do mal. 6 Vendo a mulher que a árvore era boa para se comer, agradável aos olhos, e árvore desejável para dar entendimento, tomou-lhe do fruto e comeu, e deu também ao marido, e ele comeu. 7 Abriram-se, então, os olhos de ambos; e, percebendo que estavam nus, coseram folhas de figueira, e fizeram cintas para si." 
Vejamos o comentário que faz um articulista de $O$ Estado de São Paulo, a respeito da passagem bíblica transcrita acima e da "lenda", "citada por Nascentes", como diz Houaiss (2001) na definição de pomo-de-adão:

\begin{abstract}
No episódio do Gênesis se encontra a primeira referência da Bíblia ao alimento, associado não só ao sentido de pecado, mas à idéia de que o ato de comer envolve conhecimento. No Jardim do Éden, o primeiro casal humano vivia em inocência e felicidade. Relacionava-se afetuosamente, sem culpa nem pecado (Gênesis 2.25). Entretanto, Eva cedeu à tentação da serpente, em cujo corpo se disfarçava o diabo, e ingeriu o fruto proibido, dividindo-o com Adão. O efeito da desobediência foi a perda da inocência e o conhecimento do pecado, da sexualidade e do mal. "Abriramse, então, os olhos de ambos; e, percebendo que estavam nus, coseram folhas de figueira e fizeram cintas para si" (Gênesis 3.7). A partir daquele momento, os dois se tornaram mortais, precisaram trabalhar e a mulher passou a sofrer as dores do parto.

(...) Já a voz do povo continua a relacioná-la com o pomo-de-adão, aquela saliência que os homem exibem no pescoço, devida à cartilagem tireóide. Conta-se uma história divertida. Deus teria surpreendido Adão no momento em que ele comia a maçã vetada. Assustado, o primeiro homem a engoliu sem mastigar e a fruta entalou na garganta. O "problema" foi transmitido a todos os seus descendentes masculinos. (www.estadao.com.br, 13/12/2007, artigo A inocente maçã de Adão e Eva).
\end{abstract}

Maçã-de-adão ou pomo-de-adão são lexias que têm no sema inerente 'mais acentuada nos homens', a referência ao primeiro homem, Adão, o qual remete à crença do pecado original, difundida mundialmente. O "fruto proibido", qualquer que tenha sido ele, associouse à idéia de pecado, de transgressão. Daí o vulgo associar a 'saliência da cartilagem tireóide, no pescoço', 'mais pronunciada no homem do que na mulher' ao pecado de Adão. Essa inferência tornou-se tão consistente a ponto de criar a variante não lexicalizada 'fruta do pecado', encontrada em nossa pesquisa em Iguape e, também, registrada no ALPR.

Segundo relata Rohlfs (1979, p.145-147), para designar a maçã o latim, em época muito antiga, aceitou a forma grega malum, introduzida com um tipo de maçã enxertada que se cultivava nos países helenos do Mediterrâneo. Mais tarde a forma jônico-ática melum se consagrou na boca do povo, enquanto malum se conservou como voz literária. Na Galorromânia, em vez de melum se impôs pomum, que era a designação mais corrente da fruta em geral: fr. pomme, provenzal pouma o, masculino, poum. Um tipo de maçã muito apreciada era a mala Mattiana, que deveria ser muito difundida na Península Ibérica, já que neste nome se apóiam as designações atuais: esp. manzana, astur. mazana, esp. ant. maçana, port. maçã. 
Guérios (1979, p. 161) completa a pesquisa sobre a lexia com a seguinte informação: pomo-de-adão é adaptação portuguesa do latim pomum Adami, e remonta aos israelitas, pois é traducão do hebreu tappuah ha Adam. Dizia-se também em latim morsum Adami, i. é, "pedaço mordido (da fruta) de Adão".

Gogó tem outras acepções, outros sememas, além daquele que o identifica com pomode-adão. Garganta, uma dessas acepções, é uma das variantes que aparece em nossa pesquisa. Gago, com certeza, foi atualizada por engano pelo falante/ouvinte.

Em sentido conotativo, ou seja, ativando os semas aferentes de gogó, temos a acepção "fala envolvente; lábia" e "indivíduo arrotador, alardeador". Ou seja, operou-se um deslocamento do foco da 'proeminência laríngea' para a garganta, para o 'órgão produtor da voz', e daí para 'fala envolvente', 'lábia', resultando em um indivíduo - traço 'mais acentuada nos homens' neutralizado - arrotador, alardeador.

Reproduzimos alguns comentários de sujeitos entrevistados, que constam do ALPR, referentes a esta questão. Lá eles também inferiram que o gogó é um 'sinal' do pecado original:

_ “( ... ) eles fala que é a fruta do pecado, né. Adão (en)guliu e parô aqui”.

_ "eis fala que só home tem por causo da fruta do Adão".

_ "é a fruitinha do pecado, né”.

_ "é fruito do pecado".

_ “Adão”. Referiu-se a seguir à história bíblica, completando: “diz que é o pecado, né”.

Os semas aferentes que subjazem ao processo da significação são evocados por inferência e atualizados no discurso sob a forma 'fruta do pecado'. Assim, temos que:

Pomo: fruta : : Adão: pecado

O que sobressai ao processo produção/interpretação do mundo fenomenológico, biosocial, subjacente ao processo da significação, neste caso, é um traço cultural da região estudada, a religiosidade. 
Encerramos por aqui a análise de alguns aspectos semântico-lexicais de variantes encontradas em Iguape, colhidas em pesquisa direta feita com sujeitos da região, a quem aplicamos parte do QSL do Projeto ALiB.

Iniciamos este capítulo da dissertação pela organização dos dados sob forma de tabelas, registrando os valores absolutos das respostas e calculando, por meio do programa Excel, as porcentagens de sua ocorrência. O resultado desse tratamento dos dados, do recorte selecionado em Iguape, já nos deu uma boa idéia da freqüência de cada lexia, uma pequena amostra da norma semântico-lexical da região.

Em seguida, tabulamos os dados referentes à variável faixa etária. Como a escolha destas recaiu sobre faixas etárias colocadas em pólos extremos, de um lado sujeitos de 18 a 30 anos e, de outro, sujeitos com 66 anos ou mais, pudemos ter uma visão clara da relação entre as variantes, sob a perspectiva diacrônica, ainda que a pesquisa, geolingüística, seja um recorte sincrônico do falar dos iguapenses.

Após finalizar a tabulação dos dados, a primeira conclusão que visualizamos foi que a única lexia a ter $100 \%$ de uso em Iguape, é nuca. Trata-se, indubitavelmente, de norma semântico-lexical da localidade.

\section{Quadro 5 - Lexia com $100 \%$ de freqüência}

\begin{tabular}{|l|l|l|}
\hline Questão & Lexia & Uso (\%) \\
\hline$\ldots$ isto? Apontar. & NUCA & $100 \%$ \\
\hline
\end{tabular}

Catarata foi também a única resposta à questão “... aquela pele branca ...”. Entretanto, atingiu o valor relativo de 41,67\%, tendo sido suplantada por um índice elevado de abstenções: 58,33\%.

Certas questões tiveram respostas com duas variantes para o mesmo conceito. Vejamos o quadro abaixo: 
Quadro 6 - Respostas com até duas variantes

\begin{tabular}{|l|l|}
\hline \multicolumn{2}{|c|}{ Variantes } \\
\hline cisco & poeira \\
conjuntivite & dordolhos \\
viúva & terçol \\
dentes caninos & presas \\
dente do siso & dente do juízo \\
fanhoso & fanho \\
soluço & jojoca \\
vesgo & estrábico \\
\hline
\end{tabular}

Algumas respostas apresentaram muitas variantes, como é o caso das lexias do quadro abaixo:

\section{Quadro 7 - Respostas com três ou mais variantes}

\begin{tabular}{|l|l|l|l|l|}
\hline LEXIA & \multicolumn{3}{|c|}{ VARIANTES } \\
\hline pomo-de-adão & gogó & gago & garganta & fruta do pecado \\
pálpebra & pipela & pestana & & \\
caolho & picego & cego de um olho & & \\
míope & vista curta & problema de vista & & \\
dente molar & queixal & gengiva & & \\
tatu & cera & pelanca & & \\
\hline
\end{tabular}

Outras lexias, que apresentaram mais de $50 \%$ de uso, também podem ser consideradas norma de Iguape. São elas:

\section{Quadro 8 - Norma semântico-lexical de Iguape}

\begin{tabular}{lll}
\hline Questão & Lexia & Uso (\%) \\
\hline$\ldots$ isto? Apontar. & NUCA & 100,00 \\
$\begin{array}{l}\text {... a pessoa que tem os olhos voltados para direções diferentes? } \\
\text { Completar com um gesto dos dedos. }\end{array}$ & VESGO & 83,33 \\
$\ldots$... a bolinha que nasce na ............(cf. item 89 ), fica vermelha e incha? & VIÚVA & 83,33 \\
$\ldots$... alguma coisinha que cai no olho e fica incomodando? & CISCO & 75,00 \\
$\ldots$ os últimos dentes, que nascem depois de todos os outros, em & DENTE DO SISO & 75,00 \\
geral quando a pessoa já é adulta? & BANGUELA & 75,00 \\
$\ldots$ a pessoa que não tem dentes? & TATU & 75,00 \\
$\ldots$ a sujeirinha dura que se tira do nariz com o dedo? & SOLUÇO & 75,00 \\
$\ldots$ este barulhinho que se faz? Soluçar. & FANHOSO & 58,33 \\
\hline
\end{tabular}


Passamos a tratar os dados de distribuição das lexias pelos pontos selecionados na localidade, os bairros Icapara, Rocio e Jairê, como se verifica no quadro abaixo.

\section{Quadro 9 - Distribuição das lexias pelos pontos}

\begin{tabular}{|l|c|c|c|}
\hline \multicolumn{1}{|c|}{ Lexia - \% } & Icapara & Rocio & Jairê \\
\hline pálpebra & 25 & 50 & 25 \\
cisco & 75 & 75 & 75 \\
caolho & 50 & 25 & 75 \\
vesgo & 100 & 75 & 75 \\
míope & 25 & 50 & 25 \\
viúva & 75 & 75 & 100 \\
conjuntivite & 50 & 50 & 25 \\
catarata & 50 & 25 & 50 \\
presas & 50 & 50 & 50 \\
dente do siso & 25 & 50 & 25 \\
queixal & 50 & 0 & 25 \\
banguela & 50 & 100 & 75 \\
fanhoso & 50 & 75 & 50 \\
tatu & 100 & 50 & 75 \\
soluço & 50 & 100 & 75 \\
nuca & 100 & 100 & 100 \\
gogó & 50 & 25 & 25 \\
\hline
\end{tabular}

Como podemos observar pelo quadro acima, as variantes têm distribuição bem regular entre os pontos, bairros de Iguape.

A área CORPO HUMANO, quanto às questões relativas a cabeça, envolve muitos termos técnicos, da linguagem de especialidade médica, que convivem com termos banalizados relativos ao mesmo conceito. Vejamos no quadro abaixo as preferências de uso de sexo/gênero. 
Quadro 10 - Comparação sexo/gênero x uso de termo especializado

\begin{tabular}{|l|c|c|}
\hline \multicolumn{1}{|c|}{ Lexia } & Termo Espec. & Termo Espec. \\
\hline pálpebras & 16,67 & 50,00 \\
míope & 16,67 & 50,00 \\
conjuntivite & 33,33 & 50,00 \\
Dente canino & 33,33 & 66,67 \\
dente do siso & 66,67 & 83,33 \\
Dente molar & 0,00 & 50,00 \\
\hline
\end{tabular}

\section{Quadro 11 - Comparação faixa etária x uso de termo especializado}

\begin{tabular}{|l|l|l|}
\hline \multirow{2}{*}{ Lexia } & \multicolumn{1}{|c|}{$\mathbf{1 8}-\mathbf{3 0}$ anos } & \multicolumn{1}{c|}{ 66 anos ou + } \\
\cline { 2 - 3 } permo Espec. & Termo Espec. \\
\hline estrábico & 66,67 & 0,00 \\
míope & 16,67 & 0,00 \\
conjuntivite & 66,67 & 0,00 \\
Dente canino & 50,00 & 0,00 \\
Dente molar & 50,00 & 0,00 \\
& & 0,00 \\
\hline
\end{tabular}

As mulheres e os jovens da $1^{\text {a }}$ faixa etária selecionam termos da linguagem de especialidade. Por fim, comparamos as lexias encontradas em Iguape com as registradas em outros atlas consultados.

Quadro 12 - Comparação Iguape com outros atlas

\begin{tabular}{|c|c|c|c|c|c|c|}
\hline \multirow{2}{*}{ Lexia } & \multirow{2}{*}{$\begin{array}{l}\text { Município de } \\
\text { Iguape }\end{array}$} & \multicolumn{4}{|c|}{ Atlas } & \multirow{2}{*}{ Total } \\
\hline & & ALPR & ALPB & ALS & ALMS & \\
\hline pálpebra & $\mathbf{X}$ & & & & $\mathbf{X}$ & 2 \\
\hline cisco & $\mathbf{X}$ & & $\mathbf{X}$ & & & 2 \\
\hline caolho & $\mathbf{X}$ & & & & $\mathbf{X}$ & 2 \\
\hline vesgo & $\mathbf{X}$ & & & & $\mathbf{X}$ & 2 \\
\hline viúva & $\mathbf{X}$ & & & & & 1 \\
\hline conjuntivite & $\mathbf{X}$ & & $\mathbf{X}$ & & $\mathbf{X}$ & 3 \\
\hline dente do siso & $\mathbf{X}$ & $\mathbf{X}$ & & & $\mathbf{X}$ & 3 \\
\hline banguela & $\mathbf{X}$ & $\mathbf{X}$ & & $\mathbf{X}$ & $\mathbf{X}$ & 4 \\
\hline & $\mathbf{X}$ & & & & $\mathbf{X}$ & 1 \\
\hline soluço & $\mathbf{X}$ & $\mathbf{X}$ & & $\mathbf{X}$ & & 3 \\
\hline
\end{tabular}


Antes de proceder à análise qualitativa dos dados, com base nas teorias de Pottier (1978) e Rastier (1987), fizemos a pesquisa intensiva em dicionários gerais de língua portuguesa, em dicionários de medicina, de folclore e de mitologia. Consultamos as definições das lexias/respostas mais empregadas, questão por questão, para podermos subsidiar a análise de aspectos semântico-lexicais das variantes.

Analisamos, então, cada lexia/resposta, sua rede semêmica, seus semas inerentes e aferentes, a isotopia que por ventura se instalara no interior dos sememas daquela realização pontual, e procuramos, finalmente, ligar as duas pontas das análises, quantitativa e qualitativa, concluindo pela pertinência, ou não, da relação variação semântico-lexical versus espaço geográfico.

Verificamos que algumas questões têm sememas constituídos de semas inerentes e de semas aferentes. É o caso de: cisco, terçol, catarata, tatu e pomo-de-adão.

Quadro 13 - Lexias compostas de semas inerentes e aferentes

\begin{tabular}{|c|c|c|}
\hline Isotopia & $\begin{array}{c}\text { Cisco } \\
\text { Semas Inerentes }\end{array}$ & Sema Aferente \\
\hline $\begin{array}{l}\text { recorrência do diminutivo: } \\
\text { miudezas } \\
\text { partícula } \\
\text { grânulo } \\
\text { gravetos }\end{array}$ & $\begin{array}{l}\text { pó, material sólido e heterogêneo } \\
\text { miudezas de carvão, partícula ou grânulo, } \\
\text { gravetos, } \\
\text { trazido pelas enxurradas, arrastado pelas } \\
\text { enxurradas } \\
\text { lixo, varredura } \\
\text { entra acidentalmente no olho, caída } \\
\text { especialmente no olho }\end{array}$ & poeira, pulverizada \\
\hline
\end{tabular}

Outros sememas são constituídos de semas inerentes, sofrem um processo de inferência, tornam-se produtivos e associam-se a outras lexias. 
Quadro 14 - Semas inerentes de terçol e viúva

\begin{tabular}{|c|c|c|c|}
\hline \multirow{2}{*}{$\begin{array}{l}\text { Lexia } \\
\text { Terçol }\end{array}$} & \multicolumn{2}{|c|}{ Semas Inerentes } & Lexia - Viúva ${ }^{1}$ \\
\hline & $\begin{array}{l}\text { diminutivo de hordeum, } i \text { 'cevada', } \\
\text { grãozinho de trigo } \\
\text { espécie de furúnculo do olho } \\
\text { inflamación aguda purulenta } \\
\text { circunscrita del borde del párpado } \\
\text { Presenta notable tendencia a la } \\
\text { recidiva } \\
\text { pequeno tumor inflamatório que } \\
\text { nasce no bordo das pálpebras }\end{array}$ & $\begin{array}{c}\text { separada do marido; } \\
\text { solteira } \\
\text { que perdeu o marido; } \\
\text { mulher cujo marido morreu } \\
\text { desamparo, desconsolo, } \\
\text { privação, solidão } \\
\text { e ainda não casou de novo } \\
\text { dolor }\end{array}$ & \\
\hline
\end{tabular}

Quadro 15 - Semas aferentes comuns a terçol e viúva ${ }^{2}$

\begin{tabular}{|c|c|c|}
\hline $\begin{array}{c}\text { Lexia } \\
\text { Terçol }\end{array}$ & Semas Aferentes & $\begin{array}{c}\text { Lexia } \\
\text { Viúva }^{2}\end{array}$ \\
\hline & solidão & \\
& tendencia a la recidiva & \\
& dolor & \\
\hline
\end{tabular}

Às vezes, é uma lexia que tem dois sememas que se cruzam, por evocarem semas aferentes. É o caso das lexias catarata e tatu, abaixo:

\section{Quadro 16 - Sememas de catarata: semas inerentes e aferentes}

\begin{tabular}{|c|c|}
\hline \multicolumn{2}{|c|}{ Sememas de Catarata } \\
\hline $\begin{array}{c}\text { Catarata }^{1} \\
\text { (queda d'água) }\end{array}$ & $\begin{array}{c}\text { Catarata }^{2} \\
\text { (doença dos olhos) }\end{array}$ \\
\hline \multicolumn{2}{|c|}{ Semas Inerentes } \\
\hline $\begin{array}{l}\text { queda d'água, cachoeira } \\
\text { grande volume de água que se precipita } \\
\text { do alto }\end{array}$ & $\begin{array}{l}\text { opacidade parcial ou total do cristalino; } \\
\text { torna o cristalino opaco } \\
\text { "voluminosa y bilateral" } \\
\text { "blanca" } \\
\text { "aparece generalmente después de los } \\
\text { cincuenta años" }\end{array}$ \\
\hline $\begin{array}{r}\text { Semas } \\
\mathrm{cr} \\
\mathrm{vol} \\
\mathrm{b}\end{array}$ & $\begin{array}{l}\text { ferentes } \\
\text { alino } \\
\text { linosa } \\
\text { nca }\end{array}$ \\
\hline
\end{tabular}


Quadro 17 - Sememas de tatu: semas inerentes e aferentes

\begin{tabular}{|c|c|}
\hline \multicolumn{2}{|c|}{ Lexias Tatu $^{1}$ e Tatu ${ }^{2}$} \\
\hline Tatu $^{1}$ & Tatu $^{2}$ \\
\hline \multicolumn{2}{|c|}{ Semas Inerentes } \\
\hline $\begin{array}{l}\text { mamíferos desdentados } \\
\text { que mora em toca escavada no chão } \\
\text { corpo coberto por uma carapaça formada por faixas } \\
\text { de pequenas placas ósseas }\end{array}$ & $\begin{array}{l}\text { ranho; muco } \\
\text { Nasal } \\
\text { Secreção ressequida; seco }\end{array}$ \\
\hline Aferência (relação) & Semas Aferentes \\
\hline Tatu : sujeirinha & Escondido em buraco \\
\hline Toca escavada : nariz & Duro \\
\hline Carapaça : ranho seco & Difícil de buscar \\
\hline
\end{tabular}

Quadro 18 - Sememas de pomo-de-adão: semas inerentes e aferentes

\begin{tabular}{|l|l|}
\hline \multicolumn{2}{|c|}{ Lexia Pomo-de-Adão } \\
\hline Semas Inerentes & Semas Aferentes \\
nó daência da cartilagem tireóide & nó-de-adão, maçãa-de-adão \\
mais acentuada nó da goela, gogó homens & Adão \\
Pescoço; órgão produtor da voz; garganta: & $\begin{array}{l}\text { fala envolvente; lábia. } \\
\text { proposta ou promessa que não se tem intenção de } \\
\text { cumprir 3 indivíduo arrotador, alardeador. }\end{array}$ \\
\hline
\end{tabular}




\section{CARTOGRAMAS}

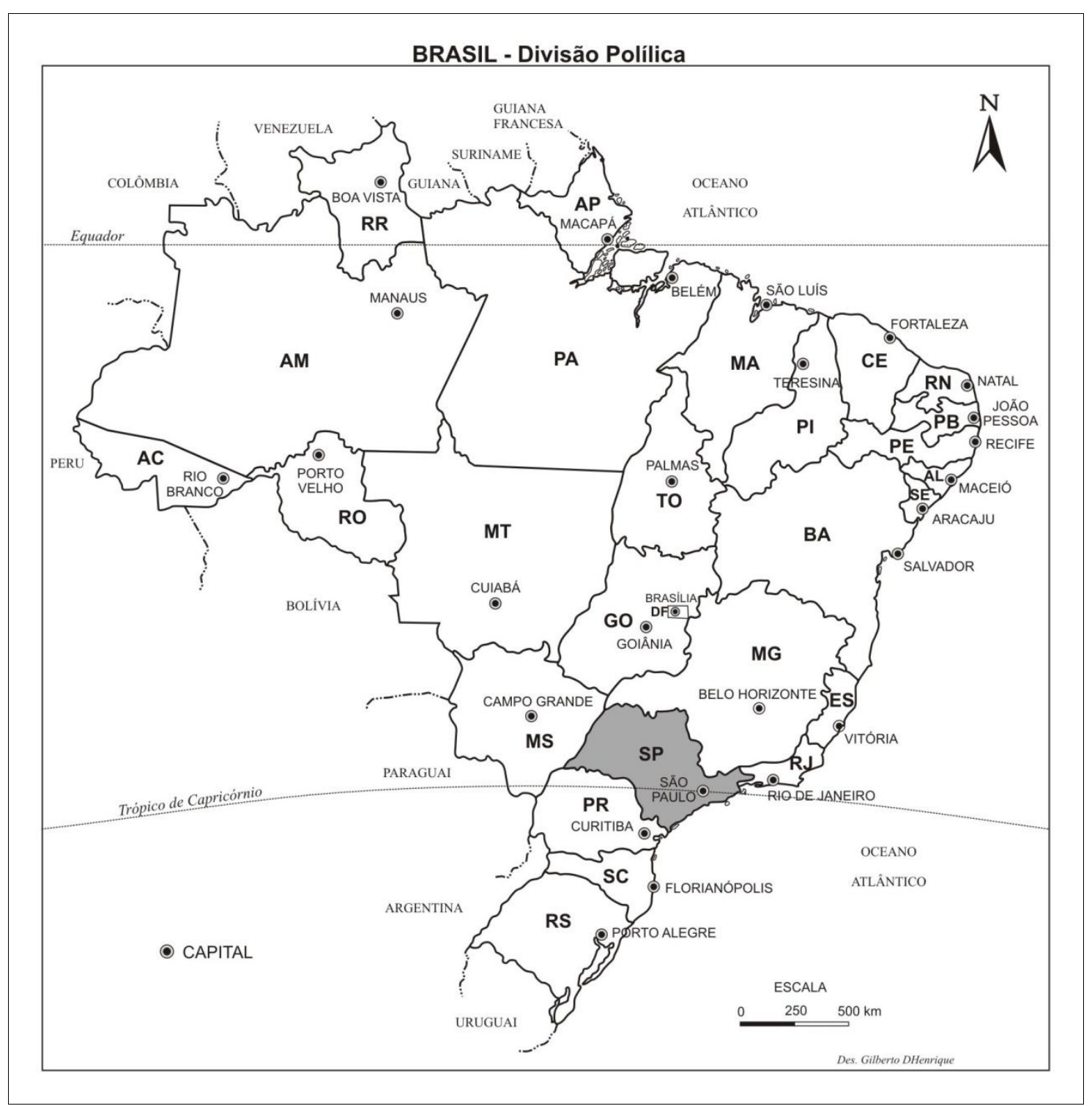




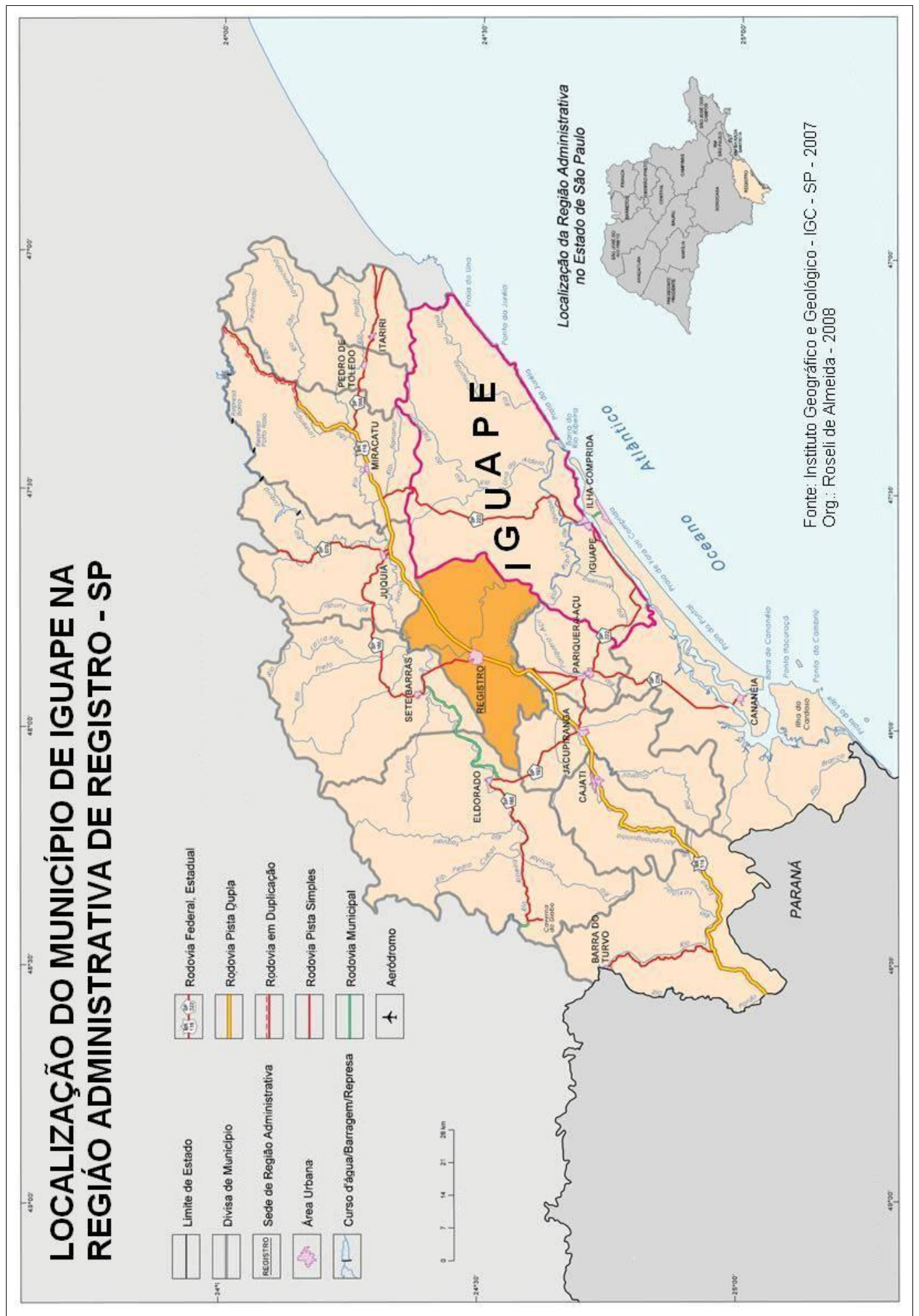


149

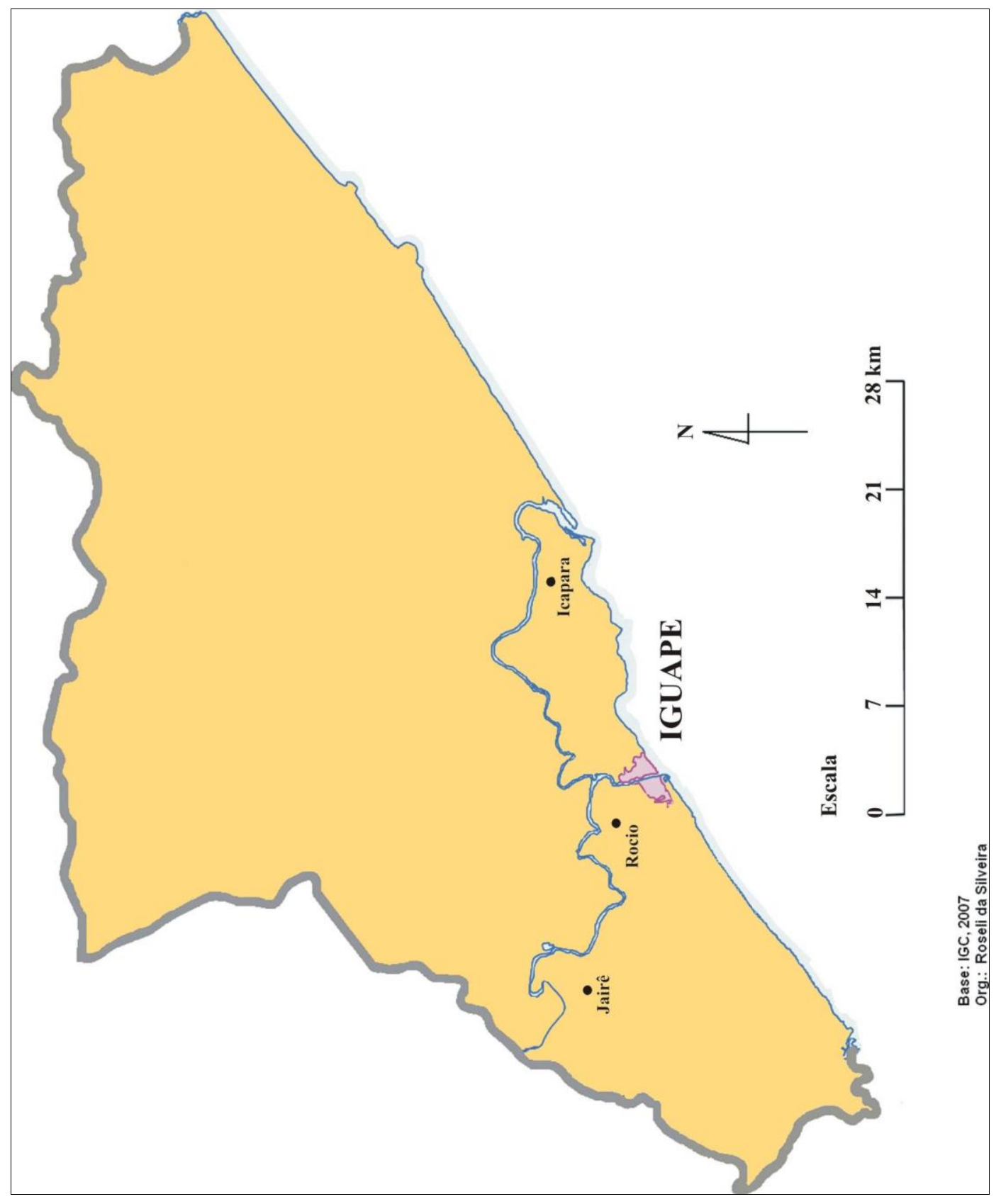




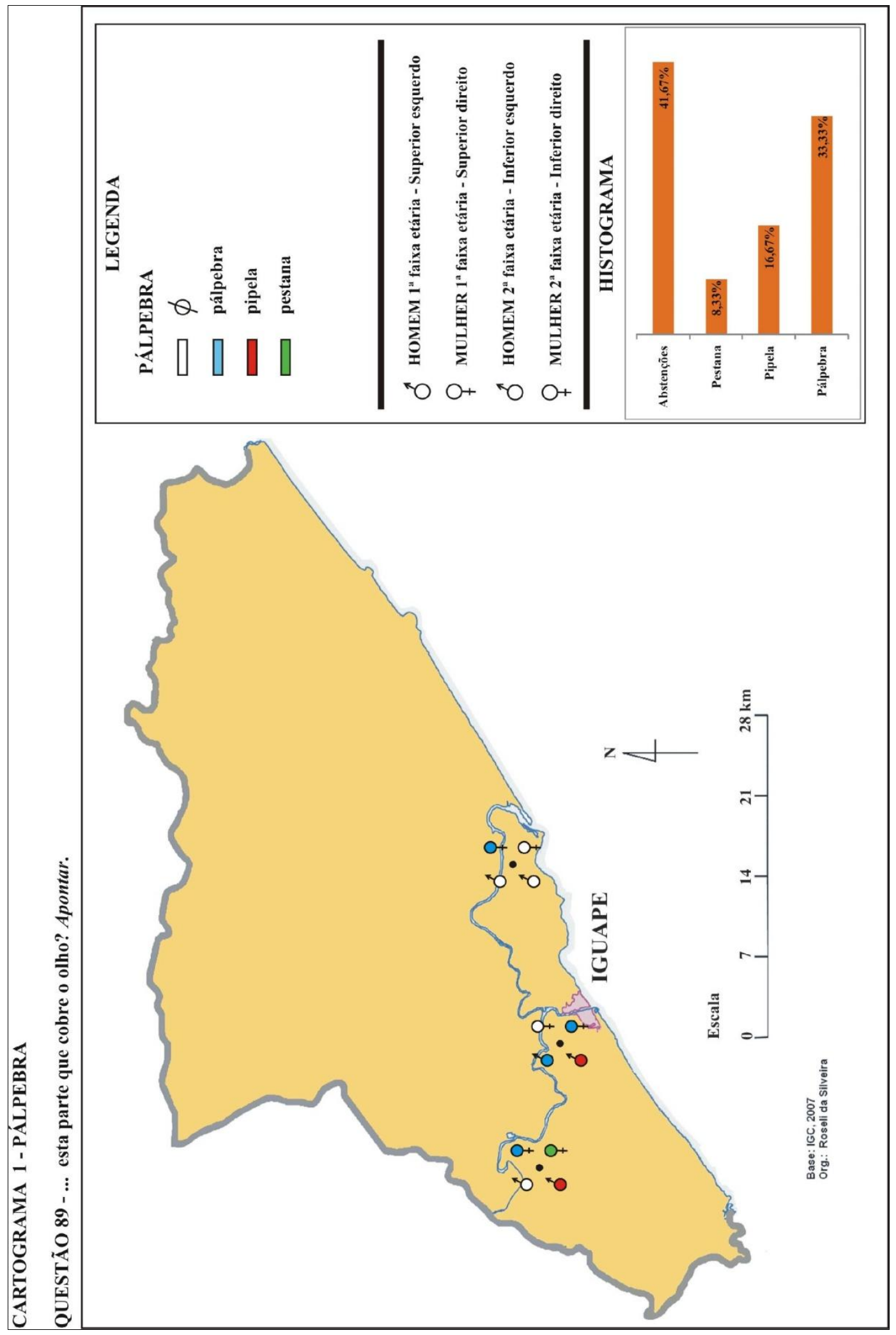




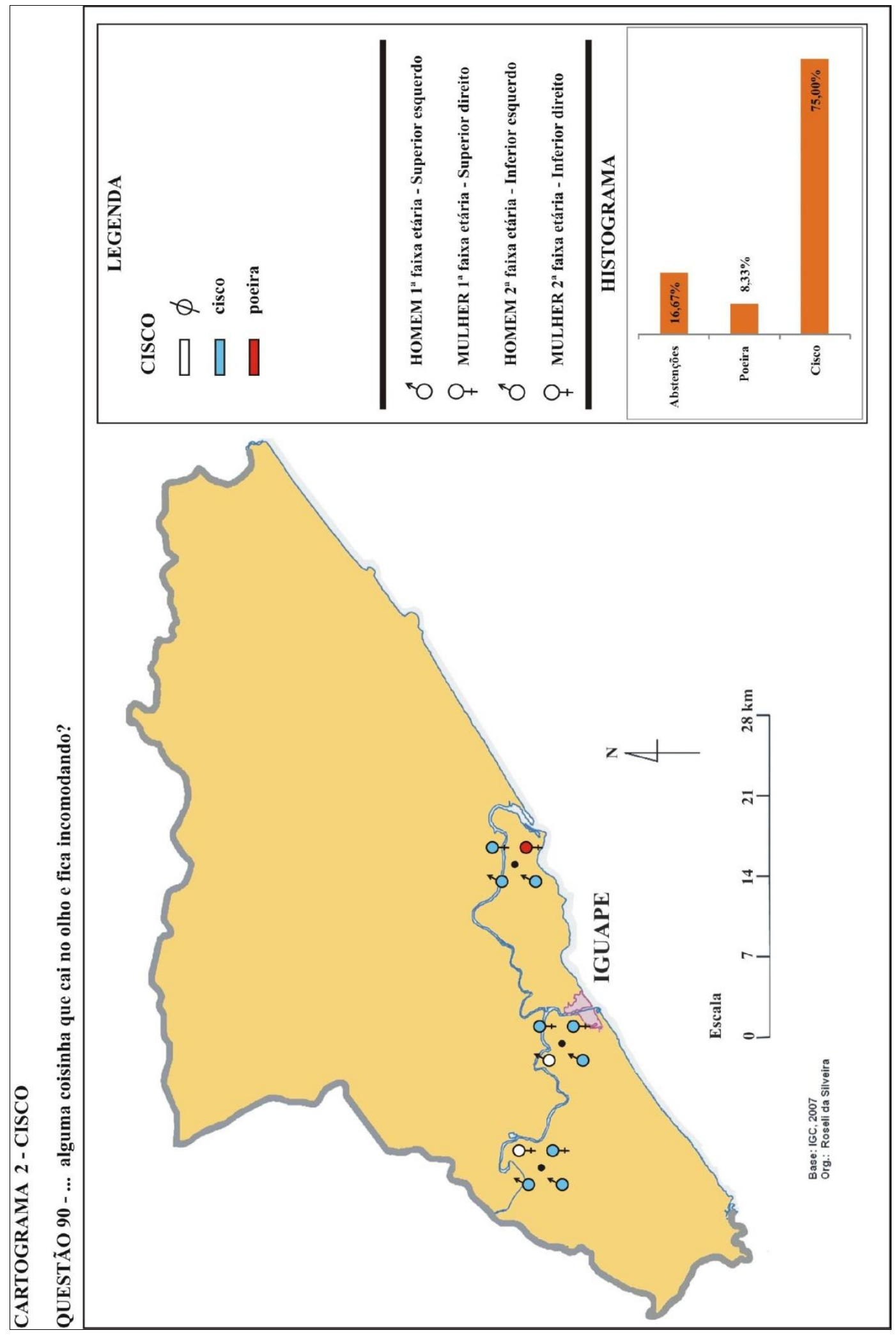




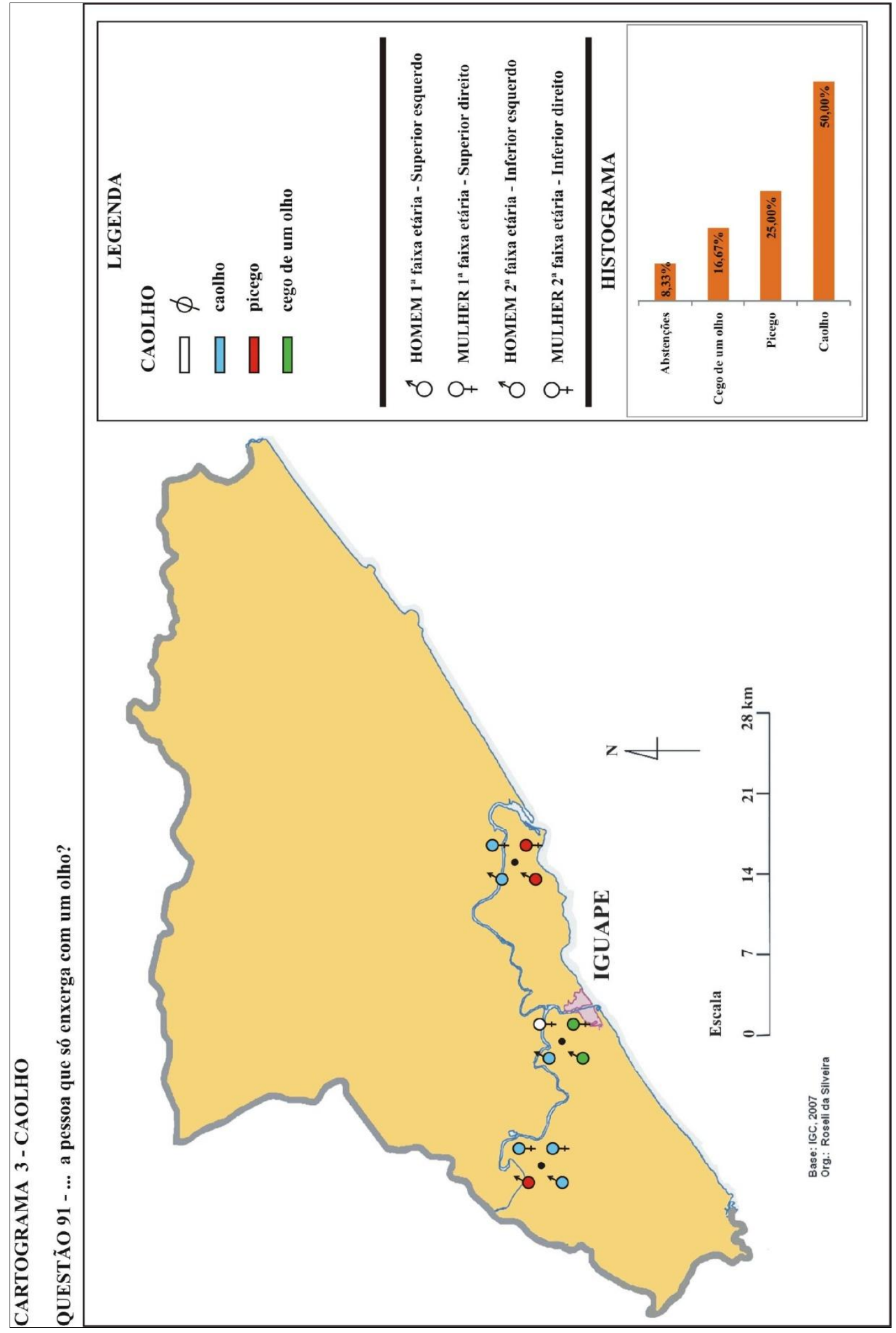




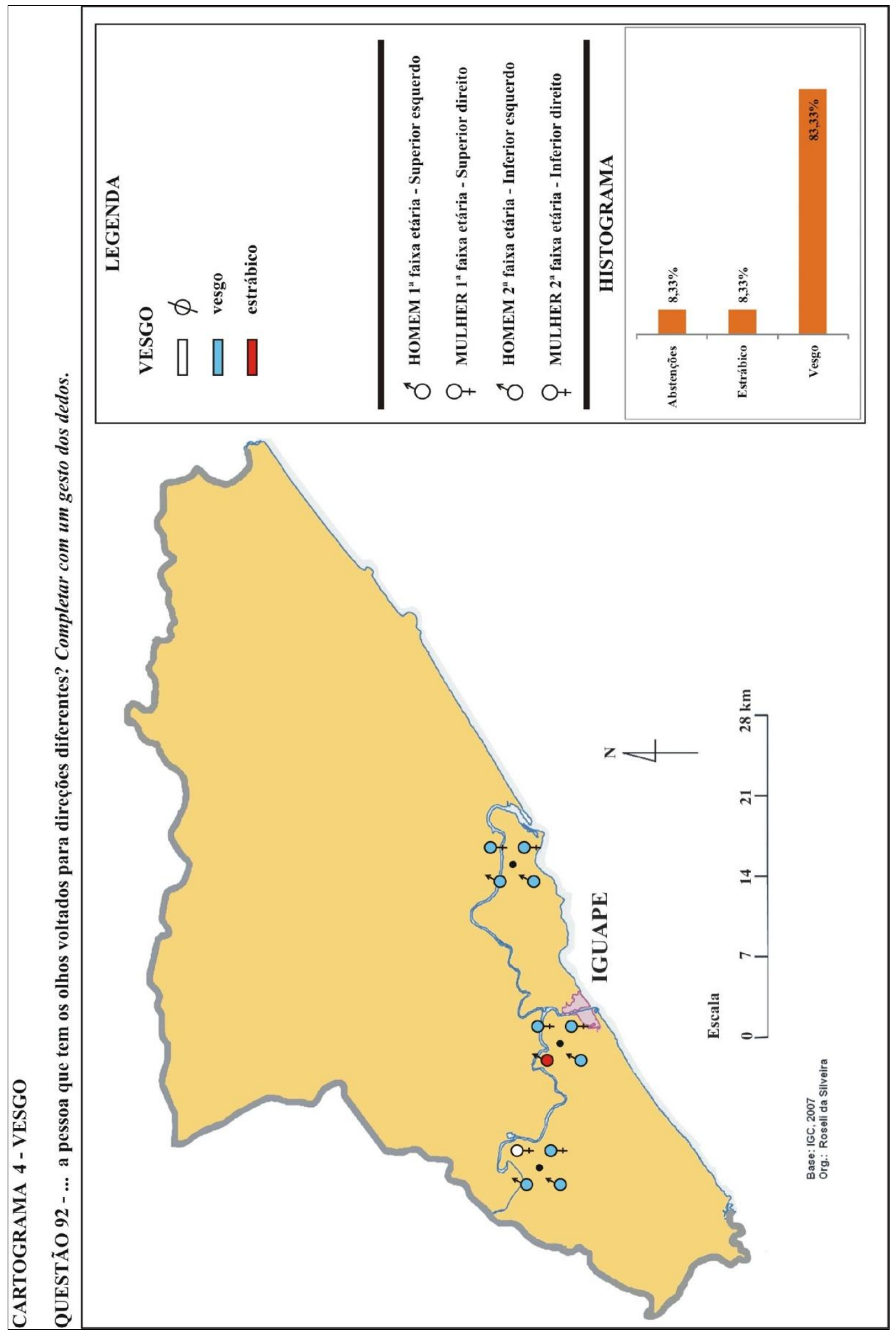




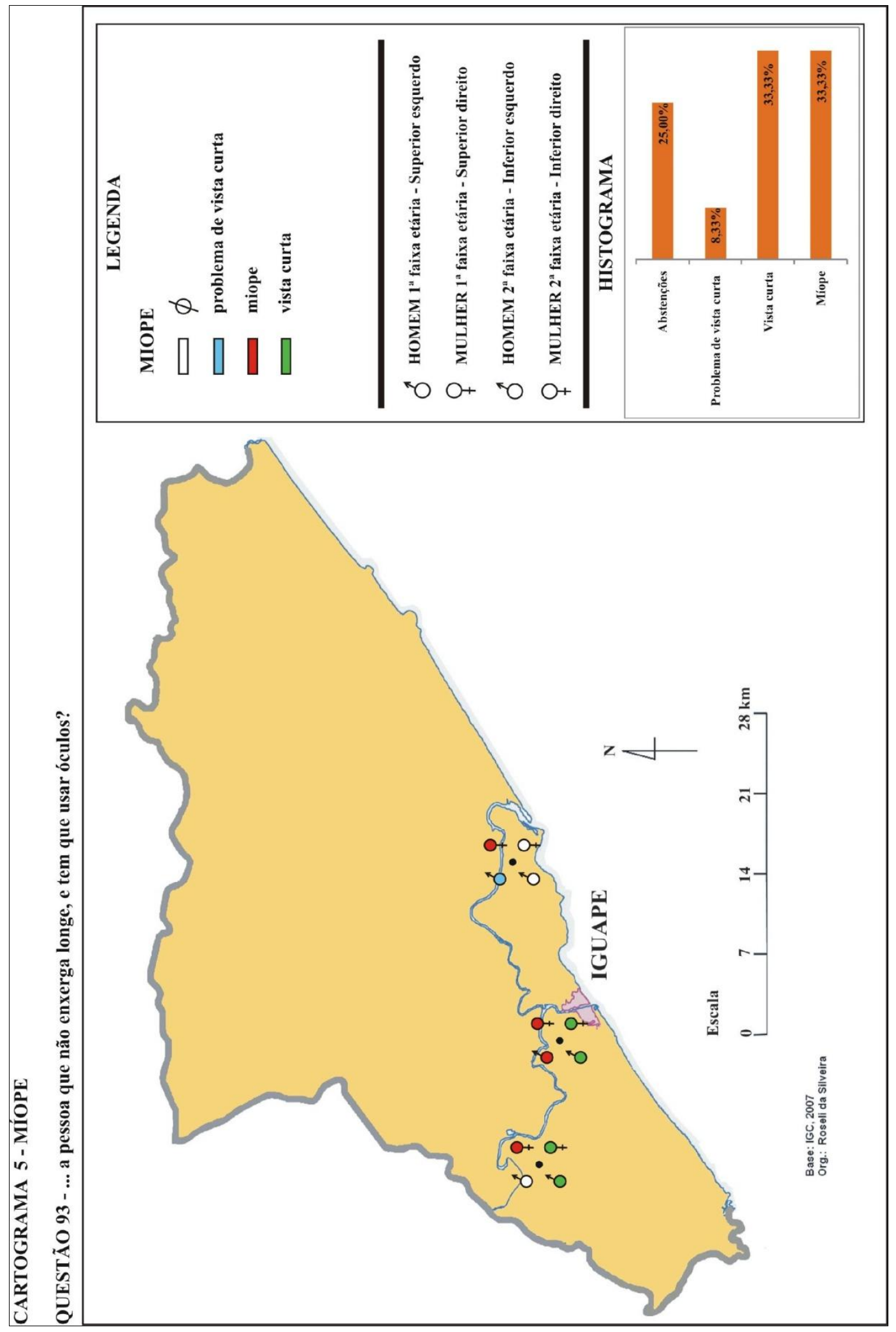




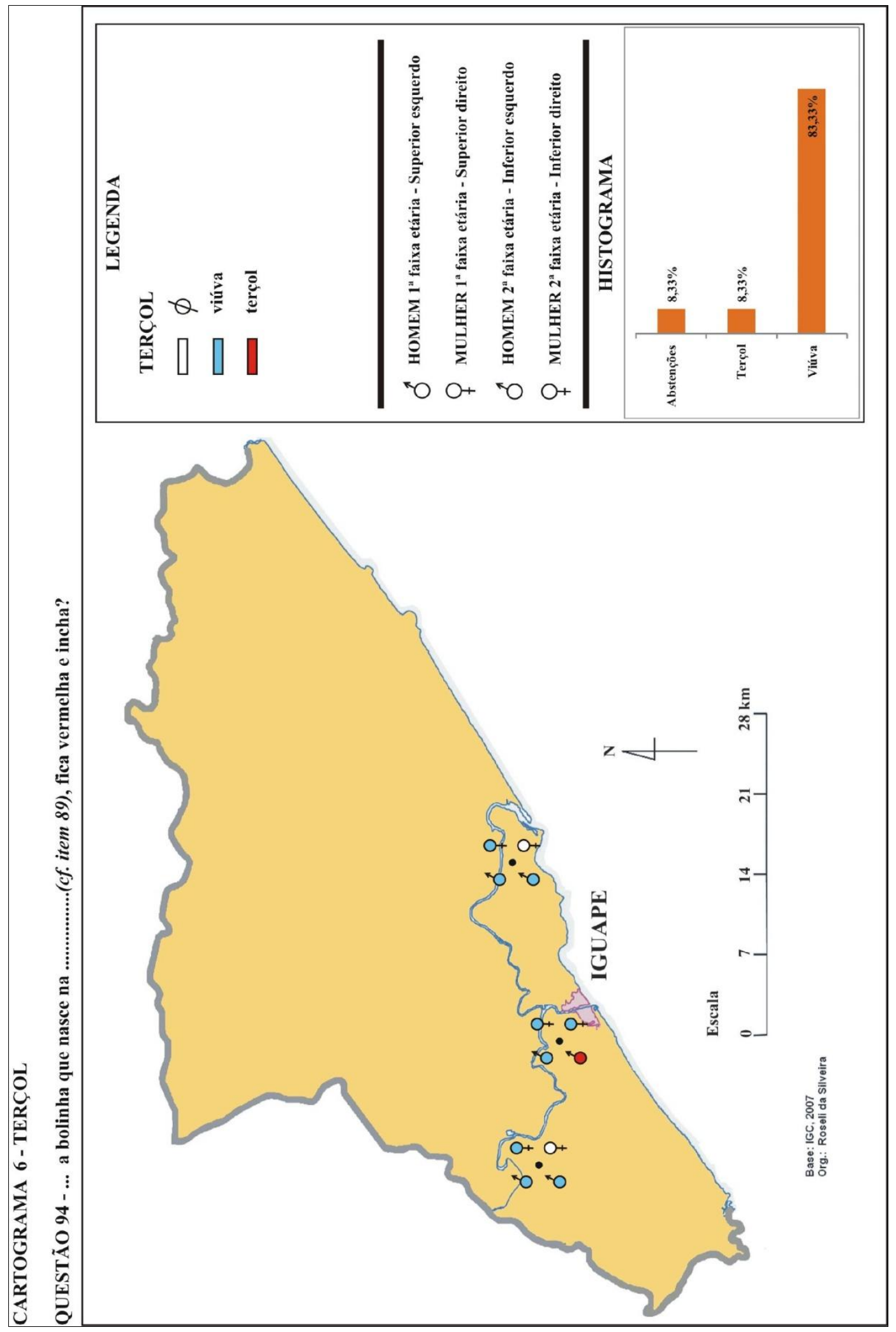




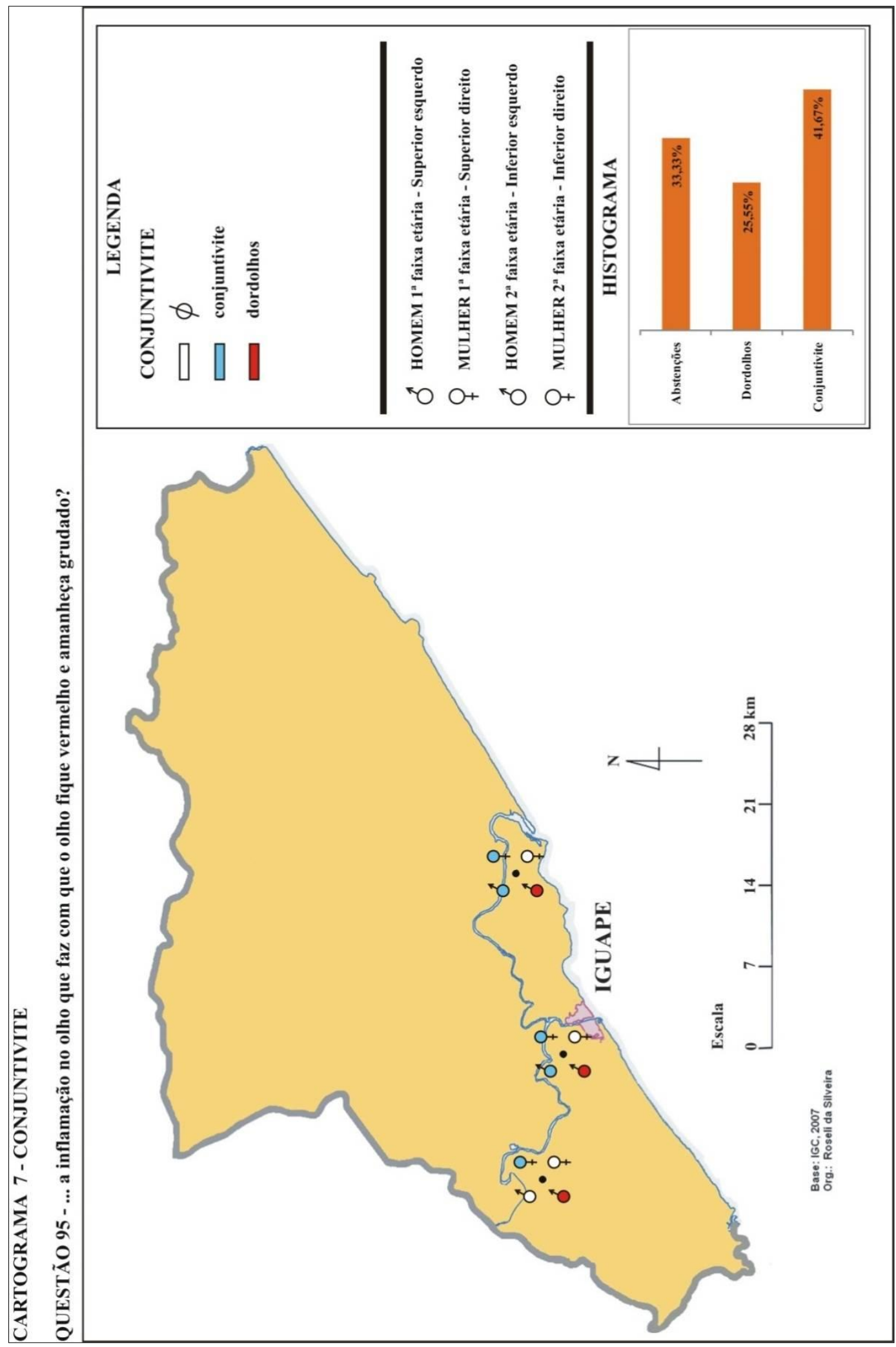




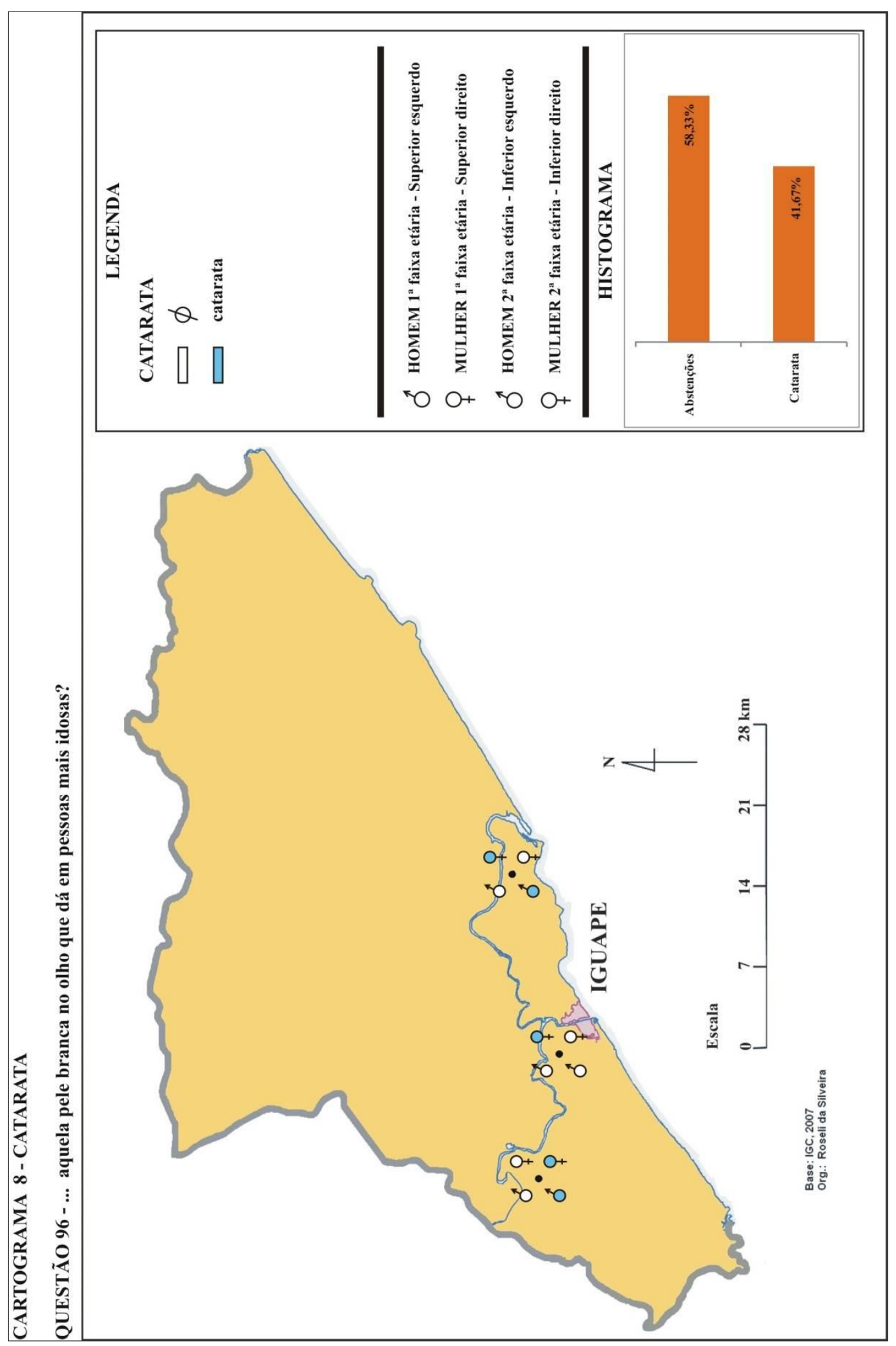




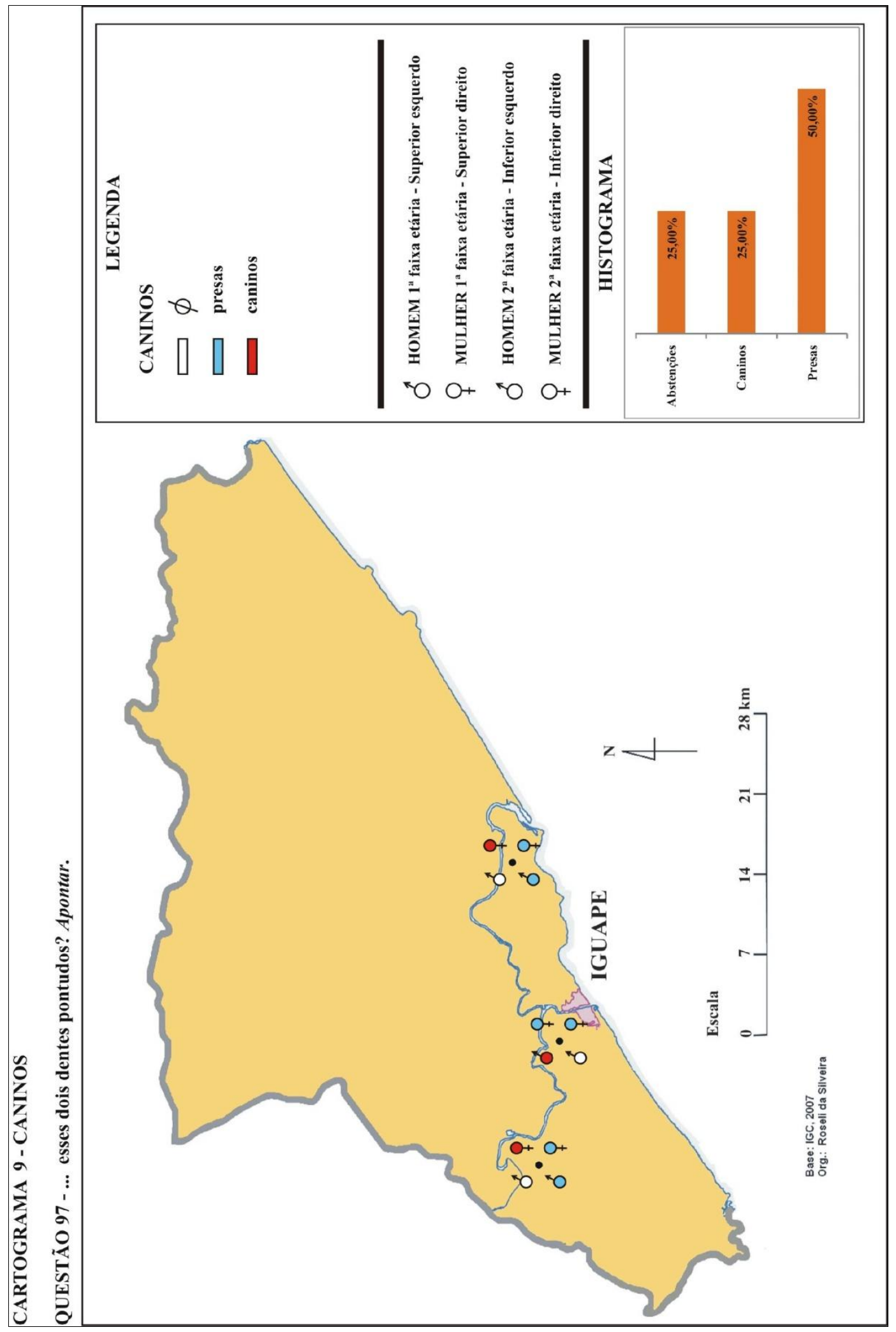




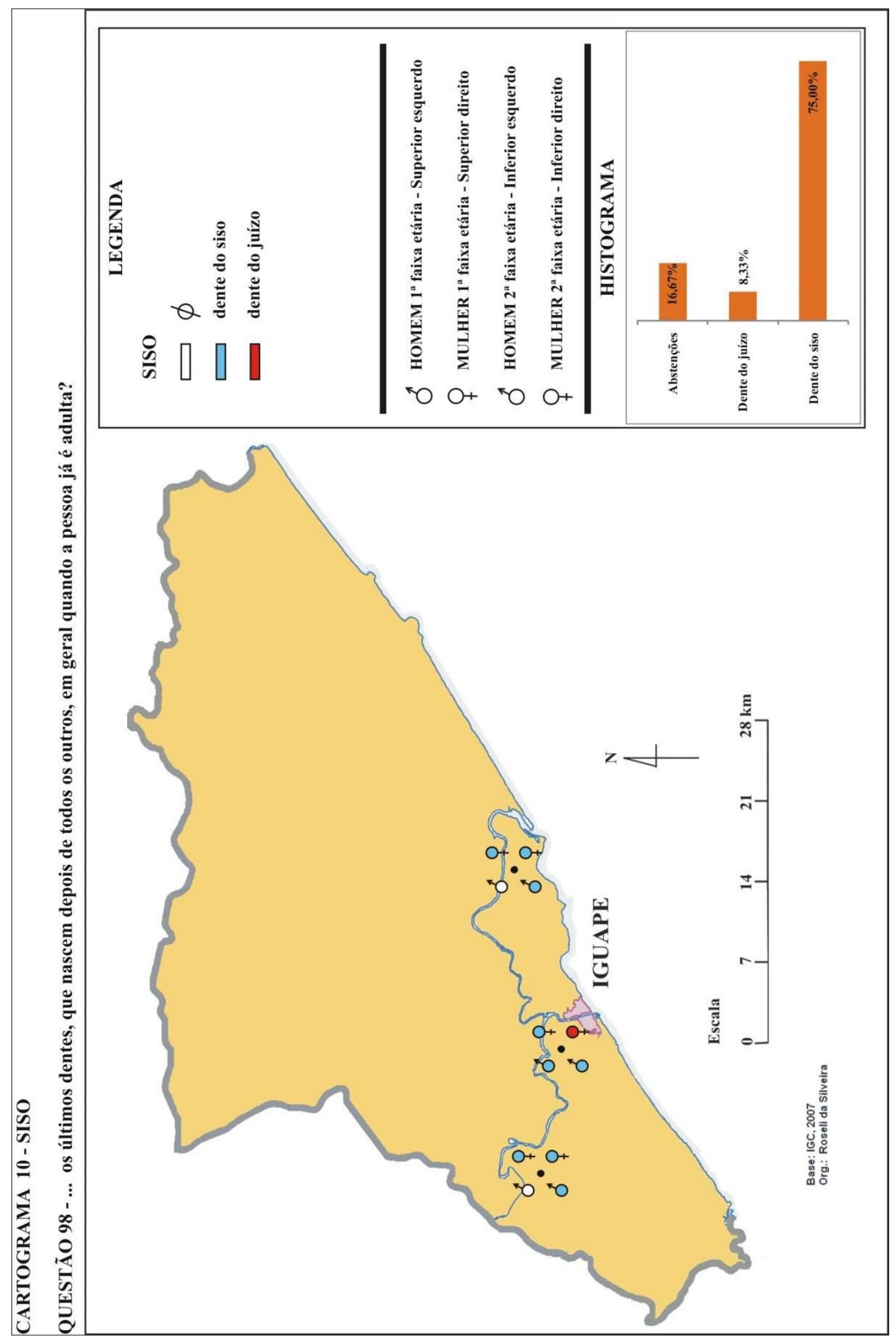




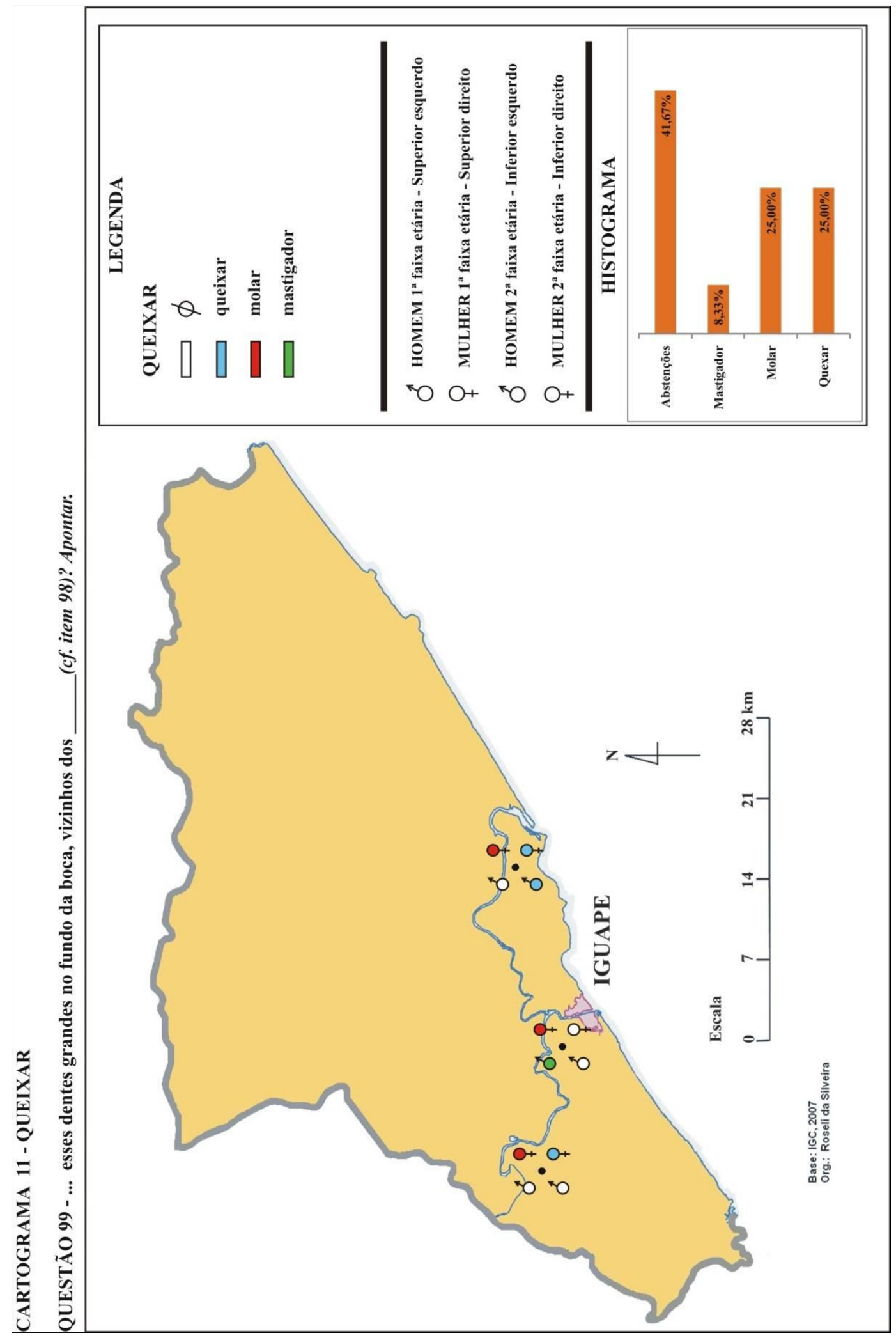




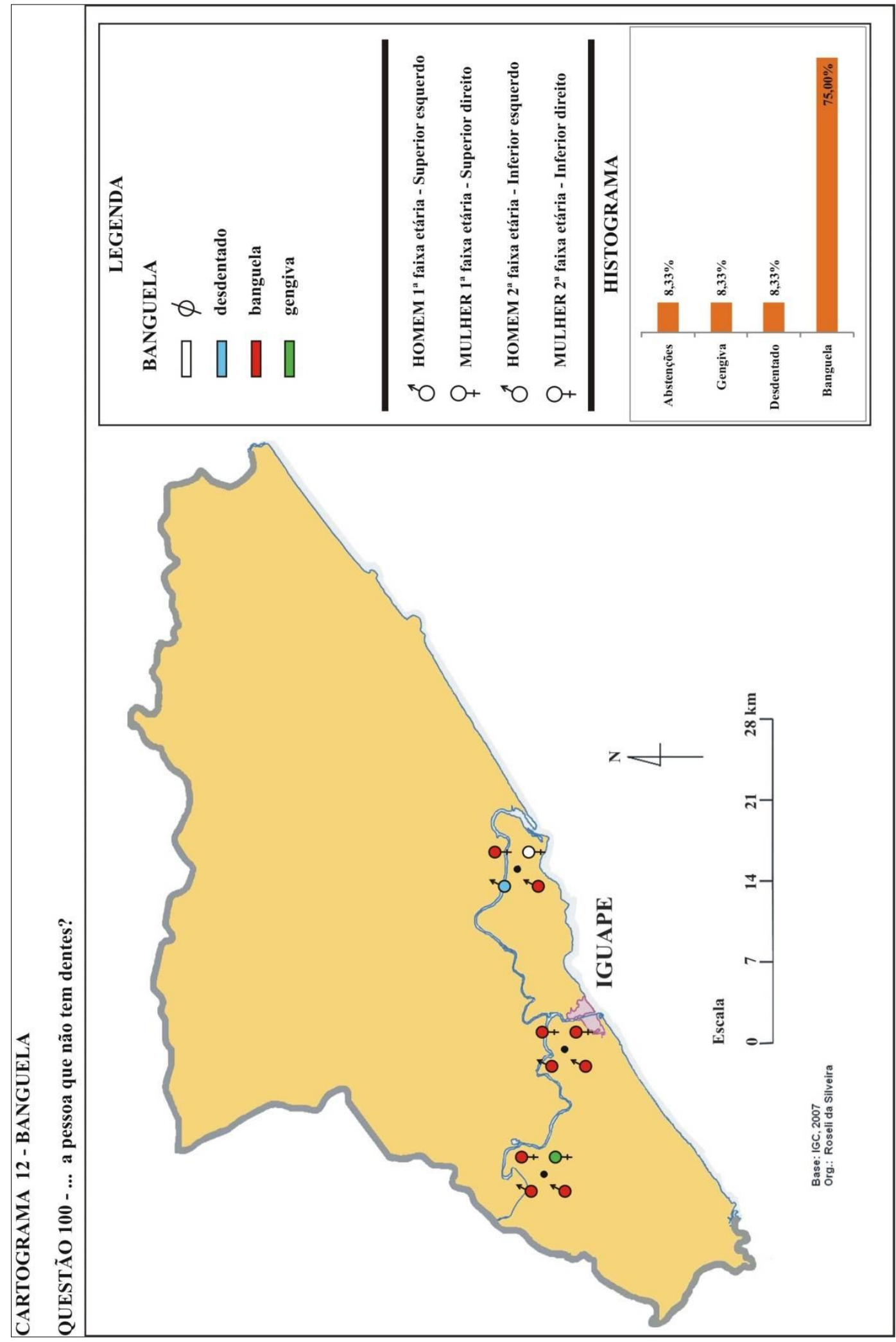




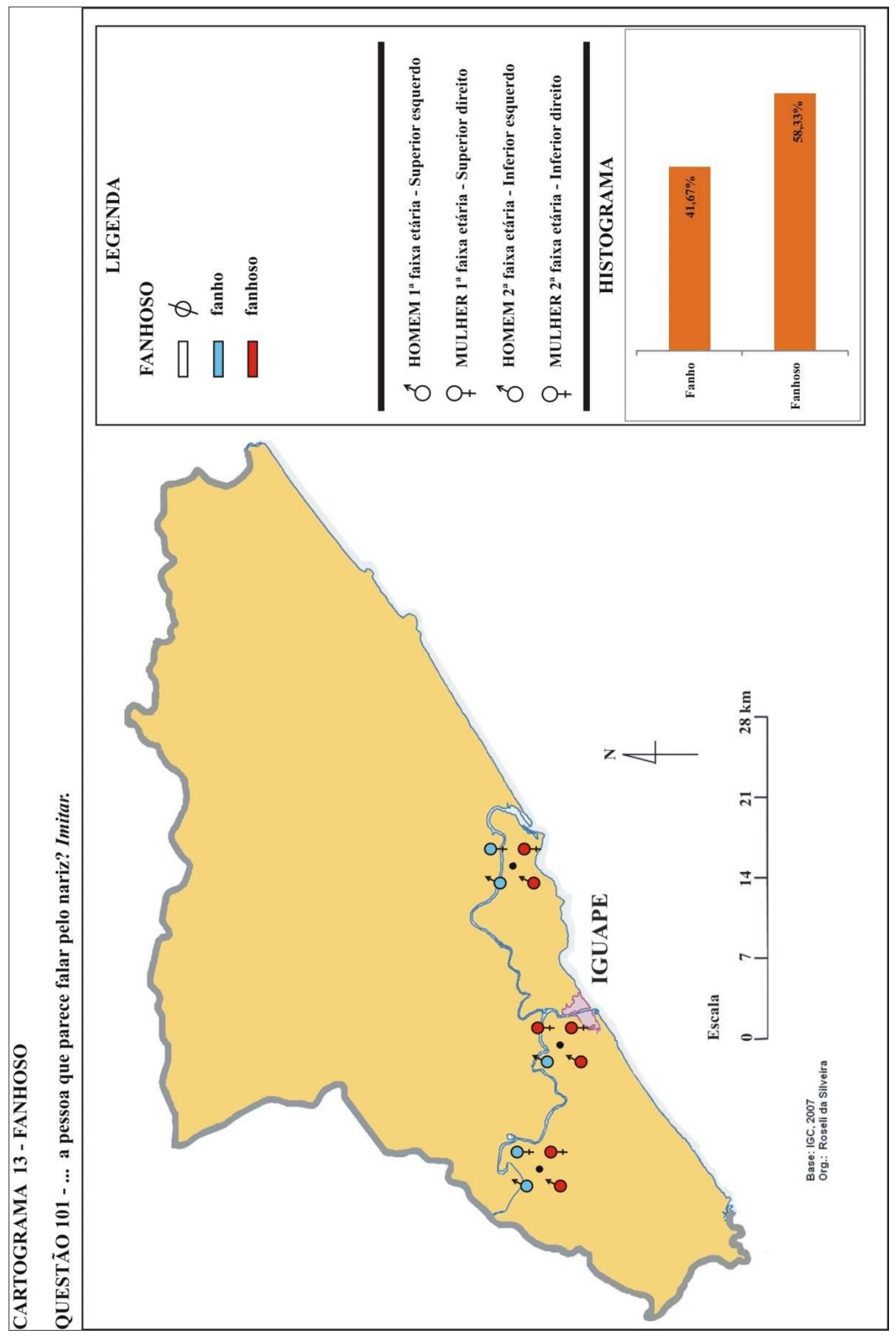




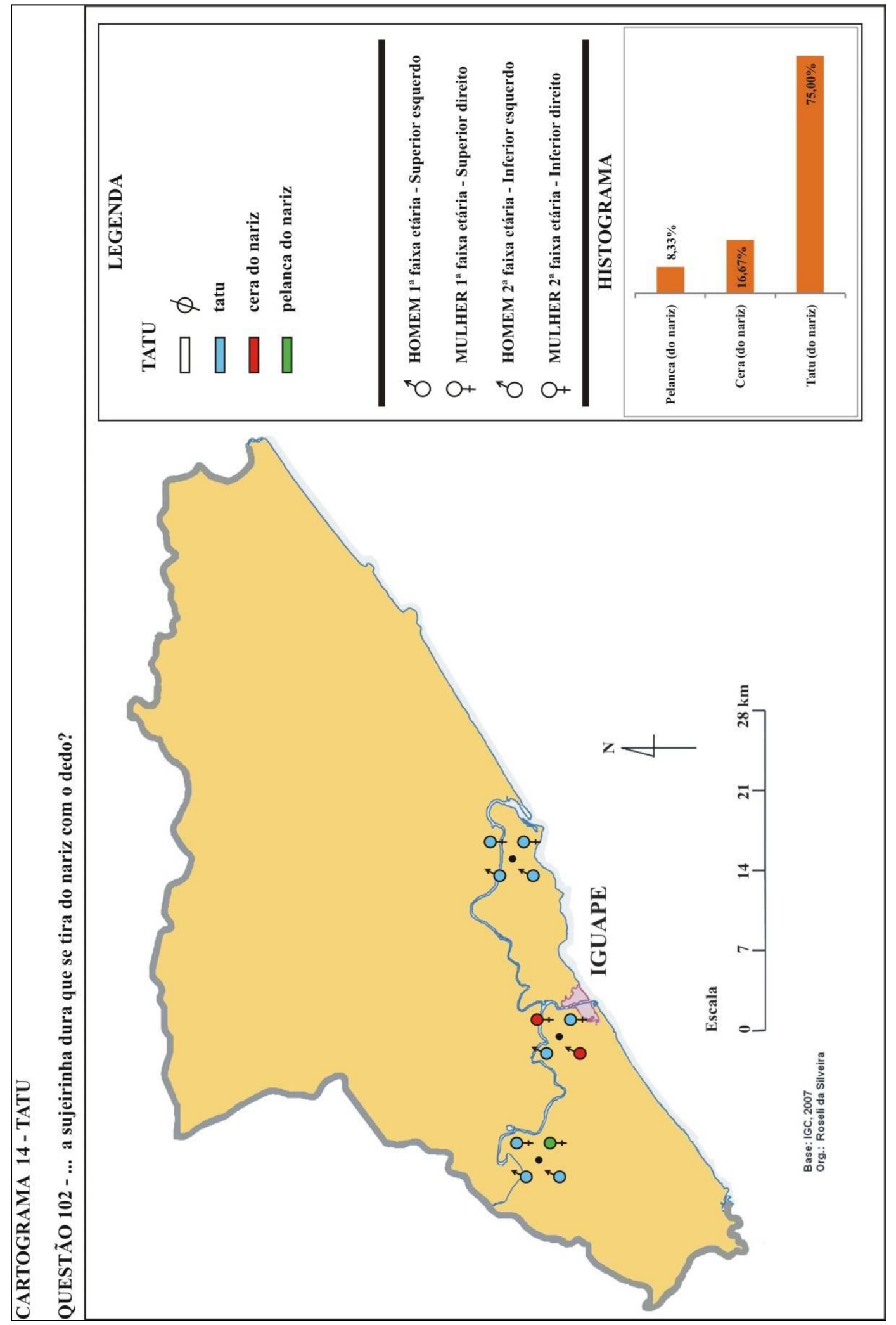




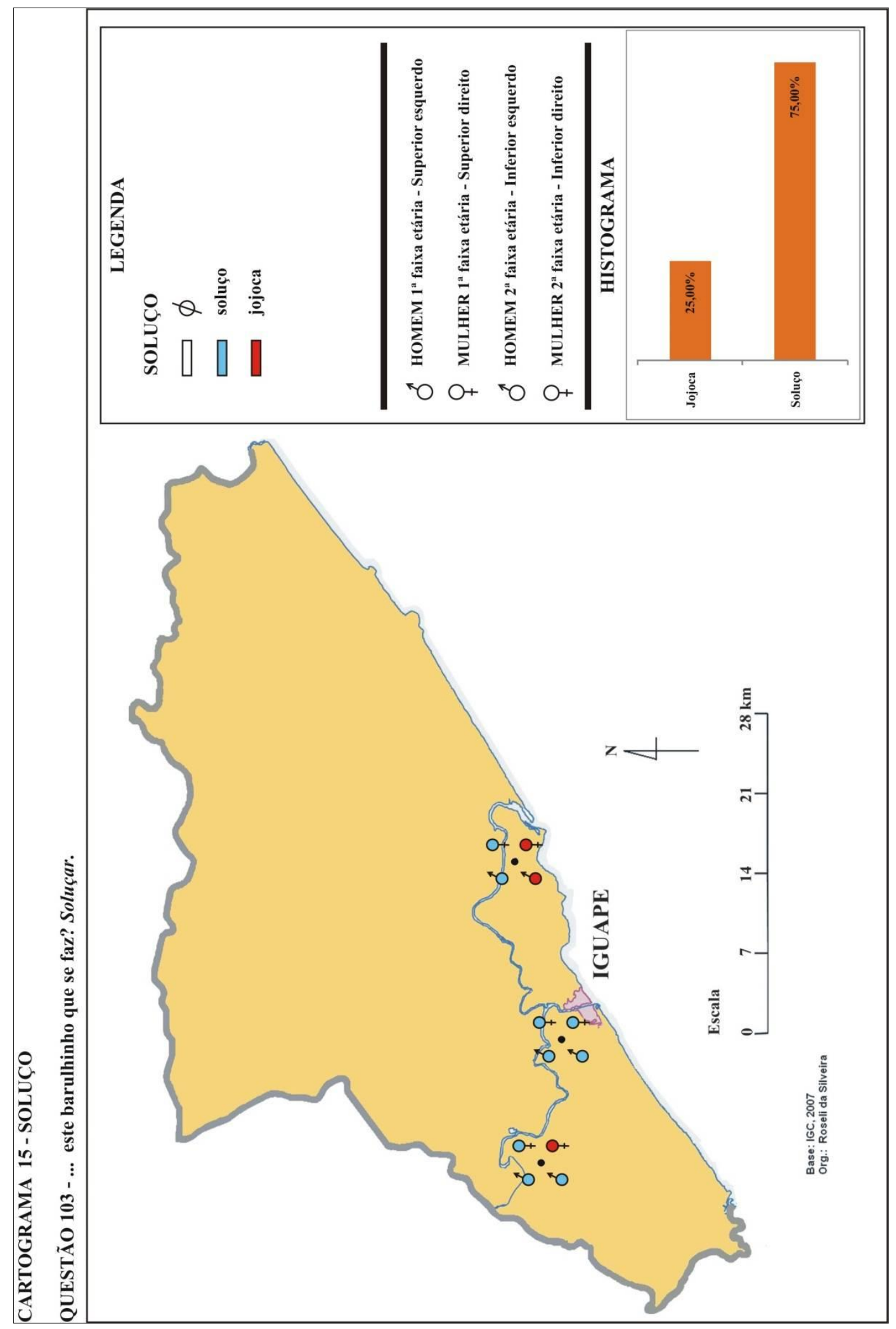




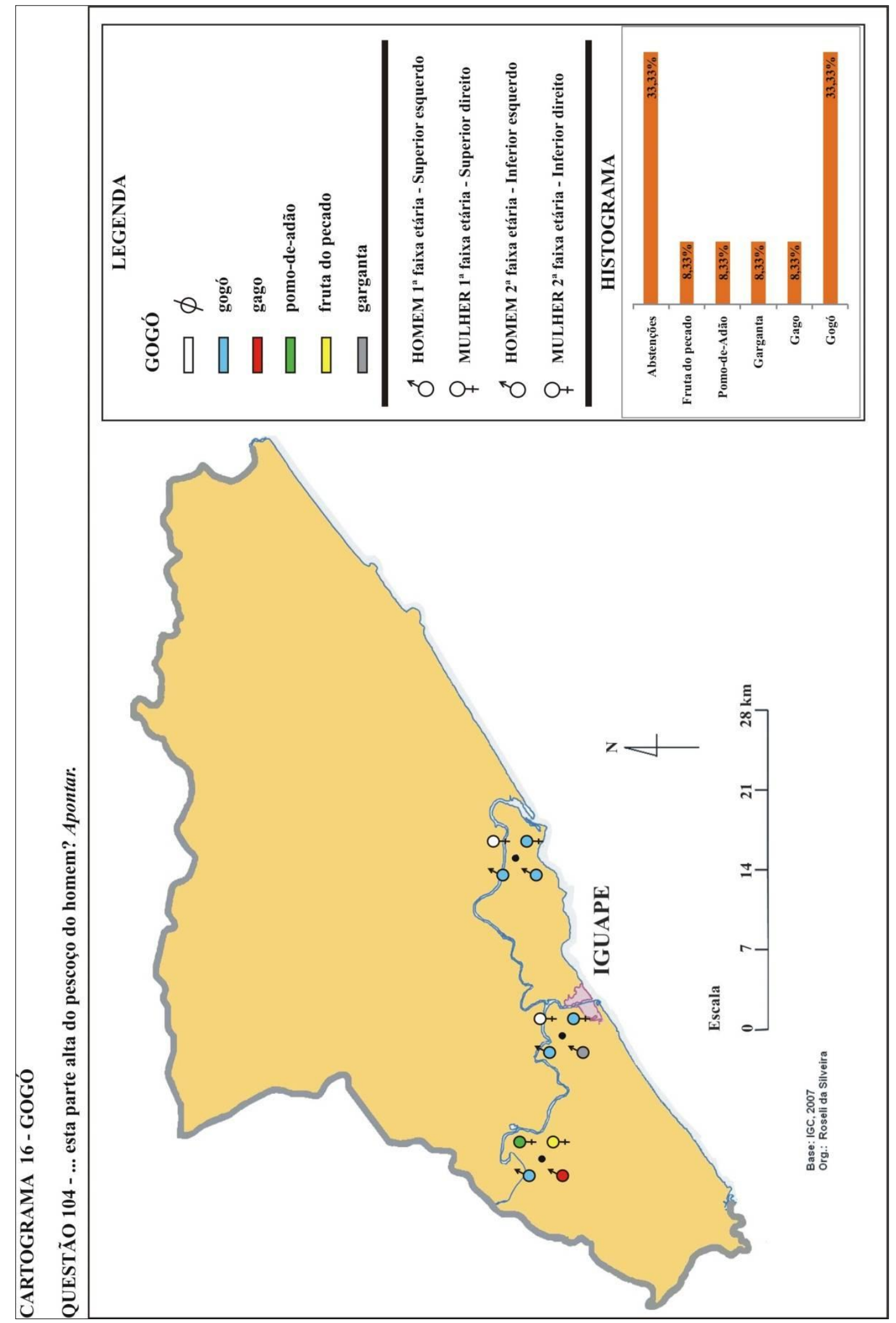




\section{CONCLUSÃO}

A ação corrosiva e homogeneizadora das modernas tecnologias de comunicação de massa tem infligido mudanças irreversíveis às línguas naturais. A constatação dessa triste realidade tem, nos últimos anos, propiciado uma expansão das pesquisas geolingüísticas, visando registrar o falar de comunidades linguiísticas ainda pouco afetadas.

As línguas são patrimônio cultural da humanidade. Elas registram toda a história sócio-político-econômico-cultural de um povo. O léxico de uma língua reúne as unidades que são a representação extralingüística da realidade. Fazer o inventário das realizações normais de uma comunidade lingüística, no sentido que lhe dá Coseriu (1982), é resgatar a sua história, a sua cultura.

O município de Iguape tem, tanto em seu passado quanto em seu presente, motivos de sobra para ser objeto de uma pesquisa sociogeolingüística. No passado, porque Iguape nasceu e cresceu com o Brasil - ela é uma cidade histórica que teve muita importância no período colonial brasileiro - e é, portanto, depositária de variantes diatópicas que revelam aspectos peculiares, ligados a sua história. No presente, porque Iguape, esquecida na região do Vale do Ribeira, possuidora de um dos mais importantes ecossistemas costeiros, por meio de sua comunidade, conservou as tradições caiçaras.

Iguape é um "bolsão de linguagem caiçara". Habitado pelos índios que ocupavam toda a faixa do litoral à época do Descobrimento, registrou a permanência, na forma de topônimos e de um léxico variado, da cultura indígena. E essas unidades lexicais, somadas às trazidas pelos africanos, foram conservadas até os dias de hoje na fala do iguapense. Em nosso trabalho, não pudemos deixar de abordar essa influência no léxico, apesar de não ser esse o objetivo central de nosso estudo.

Escolhemos Iguape para nossa pesquisa por ser a última região do litoral paulista a ser estudada, a ter registrada pelo menos parte de sua norma semântico-lexical. Além, como já 
dissemos, de essa riqueza lingüística, conservada há séculos, estar na iminência de se perder face às mudanças vertiginosas do mundo moderno. Escolhida a localidade para a pesquisa, dedicamo-nos à escolha do questionário.

A maneira consagrada pela Sociolingüística para recolher a fala de moradores de uma comunidade lingüística é a pesquisa de campo, por meio de entrevista direta. A escolha de um questionário adequado para aplicação aos sujeitos selecionados deve ser a primeira preocupação do pesquisador. Para a recolha dos dados de fala que viriam a se constituir no corpus de nossa pesquisa, escolhemos um questionário previamente elaborado e que abrangia um leque de questões sobre vários temas relativos ao homem e a sua vida diária. À semelhança de outros estudos geolingüísticos do litoral paulista, também nos utilizamos do questionário semântico-lexical do Projeto ALiB, o QSL. Optamos por ele, a fim de, assim, ser possível a comparação entre esses estudos, ainda que o questionário tenha sido modificado em um ou outro.

A escolha dos sujeitos seguiu a tendência dos atlas pluridimensionais, que inclui quatro sujeitos por localidade, distribuídos por sexo/gênero e por duas faixas etárias. O nível de escolaridade abrangeu desde o sujeito não alfabetizado até aquele com ensino fundamental completo.

Experimentalmente, aplicamos o QSL a dois sujeitos em Icapara, um dos pontos selecionados para nossa pesquisa. A aplicação dos demais questionários, doze no total, foi ao mesmo tempo desgastante e muito prazeroso. A experiência do contato direto com o povo da região, com a cultura local, foi muito enriquecedora. Deixávamos bem claro para o sujeito que queríamos registrar o nome que ele usava para o conceito que vinha formulado sob forma de pergunta. Com as respostas do questionário, referentes a apenas uma parcela da área escolhida para análise, CORPO HUMANO, compusemos o corpus de nosso estudo. 
Podemos dizer que, de posse das respostas coletadas, conseguimos radiografar parte do uso lingüístico dos falantes/ouvintes de Iguape, o falar concreto de seus moradores, a norma semântico-lexical da região, segundo a perspectiva de norma de Coseriu e utilizando os critérios da estatística lexical de Muller. Usamos norma, aqui, como o terceiro elemento da tricotomia Sistema, Norma e Fala de Coseriu, aquilo que se realiza efetivamente, e analisamos alguns de seus aspectos semântico-lexicais.

E aquilo que se realiza e se tem realizado efetivamente em Iguape, atestado pelos critérios da freqüência e da distribuição regular das lexias pelos pontos pesquisados, obtidos pela estatística lexical, resultou na norma semântico-lexical. Com referência ao corpus com o qual trabalhamos, bem entendido, aquele pequeno recorte que fizemos.

Observamos que, das dezessete lexias estudadas, apenas nиса foi realizada por $100 \%$ dos falantes, constituindo-se em norma semântico-lexical. Da mesma forma, catarata, apesar de ser realizada apenas por 41,67\% dos falantes, foi a única lexia selecionada para responder à questão “... aquela pele branca no olho que dá em pessoas mais idosas?”, sendo que as demais respostas foram abstenções.

Em muitas das questões, observamos duas ou mais variantes para o mesmo conceito, como vimos nos Quadros 6 e 7 da análise. A norma semântico-lexical, constituída de lexias de freqüência superior a $50 \%$ das respostas colhidas, constante do Quadro 8, é formada das lexias: cisco, vesgo, viúva, dente do siso, banguela, fanhoso, tatu, soluço, além de nuca.

Quanto à distribuição das lexias que constituem o inventário da norma semânticolexical pelos pontos pesquisados, concluímos que, além de freqüentes, as lexias têm distribuição regular pelos pontos selecionados.

Como já dissemos, a área semântica escolhida é composta de muitos termos especializados relativos à cabeça, que convivem com outros termos banalizados, lexias da 
língua comum. Comparando o uso destes termos quanto à variável sexo/gênero, concluímos que as mulheres dominam melhor o repertório de termos técnicos.

Quanto à variável faixa etária, verificou-se a tendência de os sujeitos jovens, de 18 a 30 anos, dominarem melhor o vocabulário técnico.

$\mathrm{Na}$ comparação das lexias encontradas em Iguape com as de outros atlas regionais, concluímos que as lexias comuns são: banguela, em quatro pesquisas; conjuntivite, dente do siso, soluço, em três; as outras lexias têm duas ocorrências; viúva, como se vê pelo Quadro 12 só aparece em Iguape. Percebemos, também, que o ALMS tem o maior número de ocorrências em comum com Iguape.

Mas, como dissemos várias vezes, nosso propósito maior era analisar aspectos semântico-lexicais das lexias de uso normalizado na localidade. Lançamo-nos a essa tarefa, procurando nos valer de ensinamentos de todas as disciplinas afins da Geolingüística, como a Lexicologia, a Lexicografia, a Terminologia, a Sociolingüística, a Etnolingüística, a Historiografia e a Geografia. A abordagem dos aspectos semânticolexicais aliou a teoria de Pottier à de Rastier, para chegarmos aos elementos mínimos diferenciais da significação.

Por fim, tentamos explicar o uso lingüístico em Iguape, e, partindo dos dados recolhidos, fizemos a relação com a análise semêmica das lexias. O resultado foi constatar o que parece óbvio: a variação está ligada diretamente à ocupação do espaço geográfico e às condições sócio-histórico-culturais da comunidade.

Apesar do caráter sincrônico próprio dos estudos geolingüísticos, o resultado obtido mostra uma visão pancrônica do falar característico da região.

Logicamente não pretendíamos esgotar o assunto nem apresentar um novo modelo de análise do léxico. Também sabemos que deve haver lacunas. Novas abordagens da variação lexical, sob outros prismas teórico-metodológicos, podem levar a melhores resultados. 
Acreditamos que, a partir dessa nossa tentativa, outros estudos venham somar-se ao nosso esforço no sentido de contribuir com a pesquisa da realidade multidialetal da língua portuguesa falada no Brasil.

A língua é dinâmica, está sempre em movimento. Essas mudanças refletem-se, sobretudo, no léxico, visto que essa é a parte do sistema lingüístico mais suscetível a mudanças por constituir um conjunto aberto. 


\section{REFERÊNCIAS}

A BÍBLIA VIDA NOVA. Tradução João Ferreira de Almeida. 14. ed. São Paulo: Sociedade Religiosa Edições Vida Nova, 1990.

AGUILERA, V. A. A geolingüística no Brasil: trilhas seguidas, caminhos a percorrer. Londrina: EDUEL, 2005.

Atlas lingüístico do Paraná. Curitiba: Imprensa Oficial do Paraná, 1994.

Os tupinismos na linguagem rural paranaense. Línguas \& Letras (UNIOESTE), v. 7, p. 99-125, 2007.

ALiB. Disponível em: <http://www.alib.ufba.br>. Acesso em 14 set. 2007.

ALINEI, M. Atlas linguistique roman (ALiR). Roma: Instituto Poligrafico e Zecca Dello Stato, Libreria Dello Stato, 1993.

ALVAR, M. Estúdios de geografia lingüística. Madri: Paraninfo, 1991.

ALVES, I. M. A delimitação da unidade lexical nas línguas de especialidade. In: BASÍLIO, M (org.). A delimitação de unidades lexicais. Série Linguagem, v. temático I. Rio de Janeiro: Grypho, 1999.

AMARAL, A. O dialeto caipira. São Paulo: Casa Editora O Livro, 1920.

ANDRADE, M. de. Poesias completas. São Paulo: Editora da Universidade de São Paulo, 1987.

ARAGÃo, M. S. S.; MENEZES, C. B. Atlas lingüístico da Paraíba: v. 1: cartas léxicas e fonéticas. Brasília: UFPB/CNPq, $1985 a$. 
AULETE, F. J. C. Dicionário contemporâneo da língua portuguesa. 5. ed. Rio de Janeiro: Delta, 1970.

BARBOSA. M. A. Léxico, produção e criatividade: processos do neologismo. São Paulo: Global, 1981.

Lexicologia: aspectos estruturais e semântico-sintáticos. In: Pais, C. T. Manual de lingüística. Petrópolis: Vozes, 1978.

BIDERMAN, M. T. C. Conceito lingüístico de palavra In: BASÍLIO, M (org.). A delimitação de unidades lexicais. Série Linguagem, v. temático I. Rio de Janeiro: Grypho, 1999.

BORBA, F. S. (org.) Dicionário UNESP do português contemporâneo. São Paulo: UNESP, 2004.

BRAIER, L. Diccionario enciclopédico de medicina. 2. ed. Buenos Aires: Lopez Libreros Editores S.R.L., 1964.

BRANDÃO, S. F. A Geografia linguiística no Brasil. São Paulo: Ática, 1991.

CABRÉ, M. T. La terminología. Teoría, metodología, aplicaciones. Barcelona: Antártida/Empunes, 1993.

CÂMARA JR., J. M. Princípios de Lingüística Geral: como introdução aos estudos superiores da língua portuguesa. $4^{\text {a }}$ ed., Rio de Janeiro: Livraria Acadêmica, 1976.

CASCUDO, L. C. Civilização e cultura: pesquisas e notas de etnografia geral. São Paulo: Global, 2004. 
Civilização e cultura: pesquisas e notas de etnografia geral. Rio de Janeiro: José Olympio, 1973.

Dicionário do folclore brasileiro. 5. ed. rev. São Paulo: Companhia Melhoramentos de São Paulo, 1979.

COMITÊ NACIONAL DO PROJETO ALiB. Atlas lingüístico do Brasil: questionário 2001. Londrina: UEL, 2001.

COSERIU, E. A Geografia Lingüística. In: COSERIU, E. O homem e a sua linguagem. Estudos de teoria e metodologia lingüística. Tradução Carlos Alberto da Fonseca e Mário Ferreira. Rio de Janeiro: Presença; São Paulo: Editora da Universidade de São Paulo, 1982.

_. Competencia linguiística: elementos de la teoría del hablar. Versión española de Francisco Meno Blanco. Madrid: Gredos, 1992.

_. Sistema, norma e fala. In: Teoria da linguagem e lingüística geral. Cinco estudos. Tradução Agostinho Dias Carneiro. Rio de Janeiro: Presença, 1979.

COSTA, F. A. P. Vocabulário pernambucano. Recife: Secretaria da Educação e Cultura, 1976.

COUTINHO, A. C. Dicionário enciclopédico de medicina. 3. ed. Lisboa: Argo, 1977.

CRISTIANINI, A. C. Atlas semântico-lexical da região do grande ABC. Tese (Doutorado), Universidade de São Paulo, São Paulo, 2008.

CUNHA, A. G. Dicionário etimológico Nova Fronteira da língua portuguesa. Rio de Janeiro: Nova Fronteira, 1986. 
CUNHA, C. Língua portuguesa e realidade brasileira. Rio de Janeiro: Tempo Brasileiro, 1968.

DIAS LOPES. A inocente maçã de Adão e Eva. Disponível em: <http://www.estadao.com.br>. Acesso em 10/10/2008.

DIEGUES, A.C. (org.). Enciclopédia caiçara, v. 2. São Paulo: HUCITEC: NUPAUB: CEC/USP, 2005a.

Enciclopédia caiçara, v. 5. São Paulo: HUCITEC: NUPAUB: CEC/USP, $2005 b$.

DRUMOND, C. Vocabulário na língua brasílica. $2^{\circ}$ vol (I-Z), $2^{\mathrm{a}}$ ed., rev. São Paulo (Brasil), 1953.

DUBOIS, J. et alii. Dicionário de linguiística. Trad. de São Paulo: Cultrix, 1978.

ELIA, S. A unidade lingüística do Brasil. Rio de Janeiro: Padrão, 1979.

ENCARNAÇÃO, M. R. T. Estudo geolingüístico de aspectos semântico-lexicais nas comunidades tradicionais do município de Ilhabela. Dissertação (Mestrado), Universidade de São Paulo, São Paulo, 2005.

FERREIRA, A. B. H. Novo Aurélio século XXI: o dicionário da língua portuguesa. 3. ed. rev.e aum. Rio de Janeiro: Nova Fronteira, 2002.

FERREIRA, A. B. H. Novo Dicionário Eletrônico-Aurélio. Versão 5.0. Positivo, 2004. 1 [CD-ROM]

FERREIRA, C.; MOTA, J.; FREITAS, J.; ANDRADE, N.; CARDOSO, S.; ROLLEMBERG, V.; ROSSI, N. Atlas lingüístico de Sergipe (ALS). Salvador: UFBA-FUNDESC, 1987. 
FORTES, R. Iguape ... Nossa História. Iguape: Editora Aa, 2000.

GARDETTE, P. Atlas linguistique et ethnographique du Lyonnais. Paris: Centre National de la Recherche Scientifique, 1968.

GREIMAS, A. J.; Courtés, J. Dicionário de semiótica. São Paulo: Cultrix, 1979.

GRIMAL, P. Dicionário da mitologia grega e romana. Tradução Victor Jabouille, 5. ed. Rio de Janeiro: Bertrand Brasil, 2005.

GUÉRIOS, R. F. M. Dicionário etimológico. Paraná: Ed.UFPR, 1979.

. Tabus lingüísticos. 2. ed. São Paulo: Companhia Editora Nacional/Editora da UFPR, 1979.

GUIA DE IGUAPE. Disponível em: <http://www.guiadeiguape.com.br >. Acesso em 11 dez. 2006.

HOUAISS, A.; VILLAR, M. S. Dicionário Houaiss da língua portuguesa. Rio de Janeiro: Objetiva, 2001.

IBAMA. Disponível em: <http://www.ibama.gov.br/apacip/index.php?id_menu=45>. Acesso em 28 out. 2007.

IBGE. Disponível em:

<http://www.ibge.gov.br/cidadesat/xtras/SINTESE.php?nomemun=Iguape\&codmun=3>. Acesso em 5 ago. 2007.

IORDAN, I. Lingüística românica. Reelaboración parcial y notas de Manuel Alvar. Madri: Ediciones Alcalá, 1967. 
LACERDA, R. C. de et alii. Dicionário de provérbios: francês-português-inglês. 2 ed. São Paulo: UNESP, 2004.

LOPES, E. Fundamentos da lingüística contemporânea. São Paulo: Cultrix, 1993.

LYONS, J. Semântica estrutural. Lisboa: Presença, 1963.

MACHADO, J. P. Dicionário etimológico da língua portuguesa. Lisboa: Editorial Confluência, 1967.

MARROQUIM, M. A língua do nordeste. São Paulo: Companhia Editora Nacional, 1945.

MELO, G. C. A língua do Brasil. Rio de Janeiro: AGIR, 1946.

MULLER, C. Principes et méthodes de statistique lexicale. Paris: Champion, 1992.

NASCENTES, A. Bases para a elaboração do atlas lingüístico do Brasil I e II. Rio de Janeiro: Ministério da Educação e Cultura, Casa de Rui Barbosa, 1958.

Bases para a elaboração do atlas lingüístico do Brasil I e II. Rio de Janeiro:

Ministério da Educação e Cultura, Casa de Rui Barbosa, 1961.

Dicionário etimológico resumido. Instituto Nacional do Livro, Ministério da Educação e Cultura, 1966.

O Linguajar carioca. Rio de Janeiro: Organização Simões, 1935.

OLIVEIRA, D. P. (org.) Atlas lingüístico de Mato Grosso do Sul. Campo Grande: UFMS, 2007. 
PEREIRA JR., C. A. (org.). Iguape: princesa do litoral, Terra do Bom Jesus, bonita por natureza! São Paulo: Noovha América, 2005.

POTTIER, B. Estrutura lingüística do português. São Paulo: Difusão Européia, 1972.

Lingüística geral: teoria e descrição. Tradução Walmírio Macedo. Rio de Janeiro: Presença, 1978.

RASTIER, F. Sémantique interpretative. Paris: Presses Universitaires de France, 1987.

RIBEIRO, J. et al. Esboço de um atlas lingüístico de Minas Gerais. v. 1. Rio de Janeiro: Fundação Casa Rui Barbosa, 1977.

ROBERTO FONTES. Disponível em: <http://www.robertofortes.fotoblog.com.br >. Acesso em 24 jun 2007.

ROHLFS, G. Estúdios sobre el léxico românico. Reelaboração parcial e notas de Manuel Alvar. Madri: Gredos, 1979.

ROSSI, N.; FERREIRA, C.; INSENSEE, D. Atlas prévio dos falares baianos. Rio de Janeiro: INL- MEC, 1963.

Atlas prévio dos falares baianos: introdução, questionário comentado e elenco das respostas transcritas. Rio de Janeiro: INL; MEC, 1965.

SANTOS, I. P. Proposta de análise das designações de estrela cadente em atlas lingüísticos brasileiros. In: SEMINÁRIO DO CENTRO DE ESTUDOS LINGÜÍSTICOS E LITERÁRIOS DO PARANÁ, 27, 2005 [CD-ROM]. 
Proposta de análise do aspecto semântico-lexical em atlas linguísticos regionais brasileiros. In: CUNHA, C. S. (org.). Estudos geo-sociolingüísticos. Rio de Janeiro: UFRJ: Pós-Graduação em Letras Vernáculas, 2006, p. 83-97.

SAUSSURE, F. Curso de lingüística geral. São Paulo: Cultrix/Edusp, 1972.

SILVA NETO, S. Guia para estudos Dialectológicos. 2. ed. Belém: Instituto Nacional de Pesquisas da Amazônia, 1957.

VALE DO RIBEIRA. Disponível em: <http://www.valedoribeira.gov.br>. Acesso em 15 out 2006.

VILELA, M. Estruturas léxicas do português. Coimbra: Livraria Almedina, 1979.

WEINREICH, U; LABOV, W. ; HERZOG, I. Fundamentos empíricos para uma teoria da mudança lingüística. Trad. de Marcos Bagno, rev. técn. de Carlos Alberto Faraco.São Paulo: Parábola Editorial, 2006. 


\section{ANEXOS}

\section{ANEXO A - Questionário semântico-lexical do Projeto ALiB - Área Semântica CORPO HUMANO}

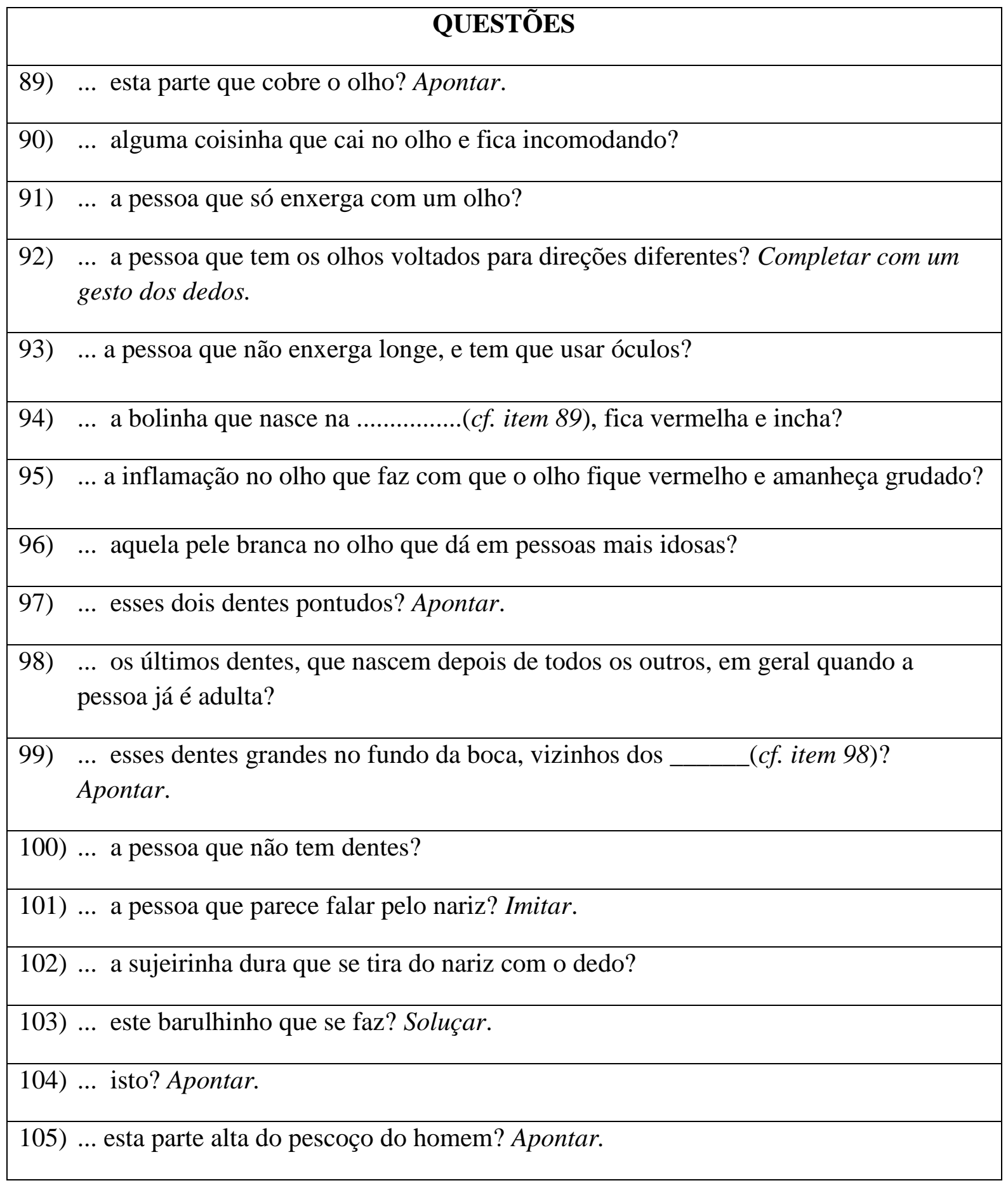


ANEXO B - Ficha do sujeito - Modelo do Projeto ALiB

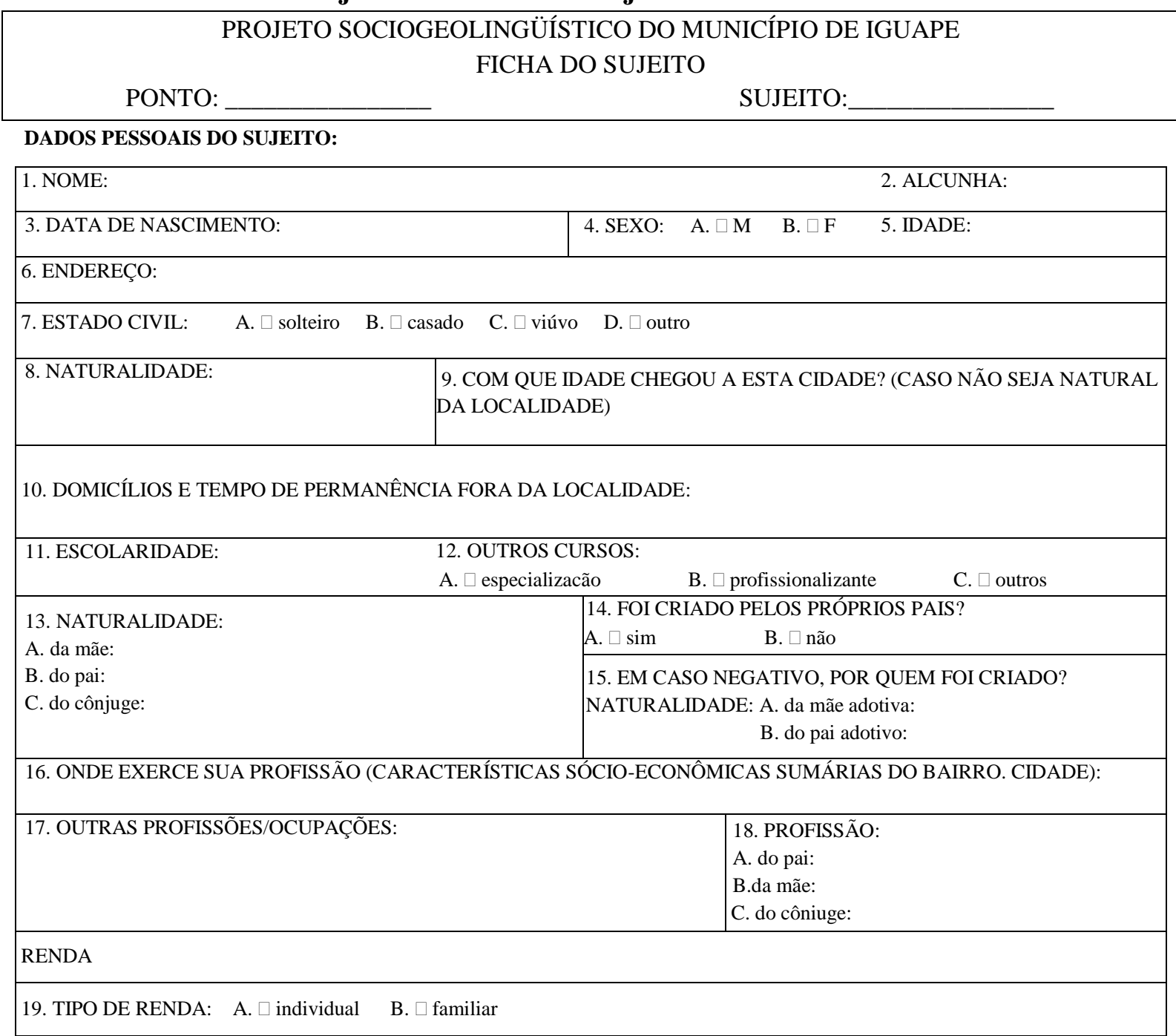

CONTATO COM OS MEIOS DE COMUNICAÇÃO:

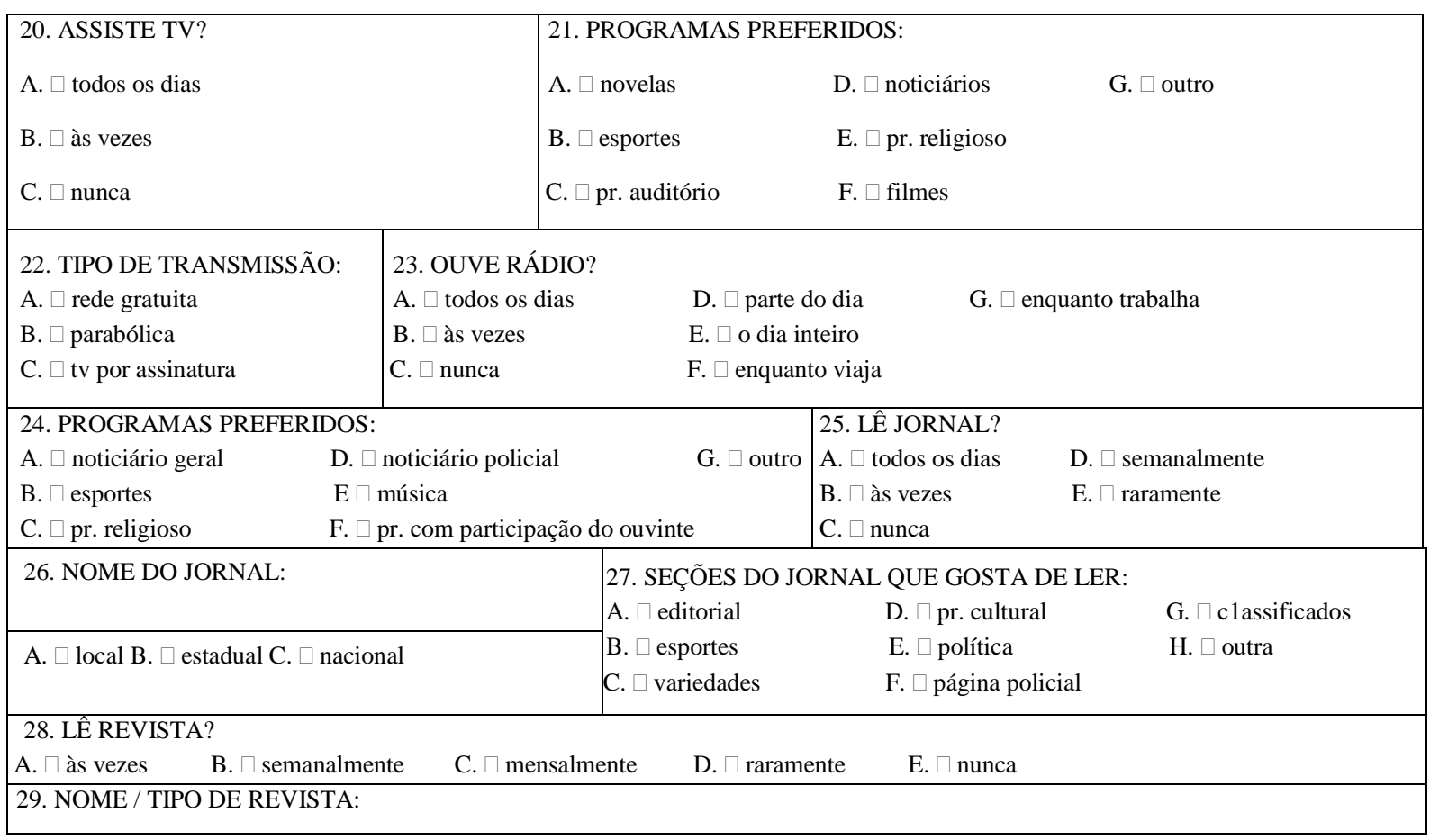


PARTICIPAÇÃO EM DIVERSÕES

\begin{tabular}{|lcrrr|}
\hline & FREQUENTEMENTE & ÀS VEZES & RARAMENTE & NUNCA \\
30. CINEMA & A. $\square$ & B. $\square$ & C. $\square$ & D. $\square$ \\
31. TEATRO & A. $\square$ & B. $\square$ & C. $\square$ & D. $\square$ \\
32. SHOWS & A. $\square$ & B. $\square$ & C. $\square$ & D. $\square$ \\
33. MAN. FOLCLÓRICAS & A. $\square$ & B. $\square$ & C. $\square$ & D. $\square$ \\
34. FUTEBOL & A. $\square$ & B. $\square$ & C. $\square$ & D. $\square$ \\
35. OUTROS ESPORTES & A. $\square$ & B. $\square$ & C. $\square$ & D. $\square$ \\
36. OUTROS & A. $\square$ & B. $\square$ & C. $\square$ & D. $\square$ \\
\hline 37. QUE RELIGIÃO OU CULTO PRATICA? & & & & \\
\end{tabular}

PARA PREENCHIMENTO APÓS A ENTREVISTA

38. CARACTERÍSTICAS PSICOLÓGICAS DO SUJEITO:

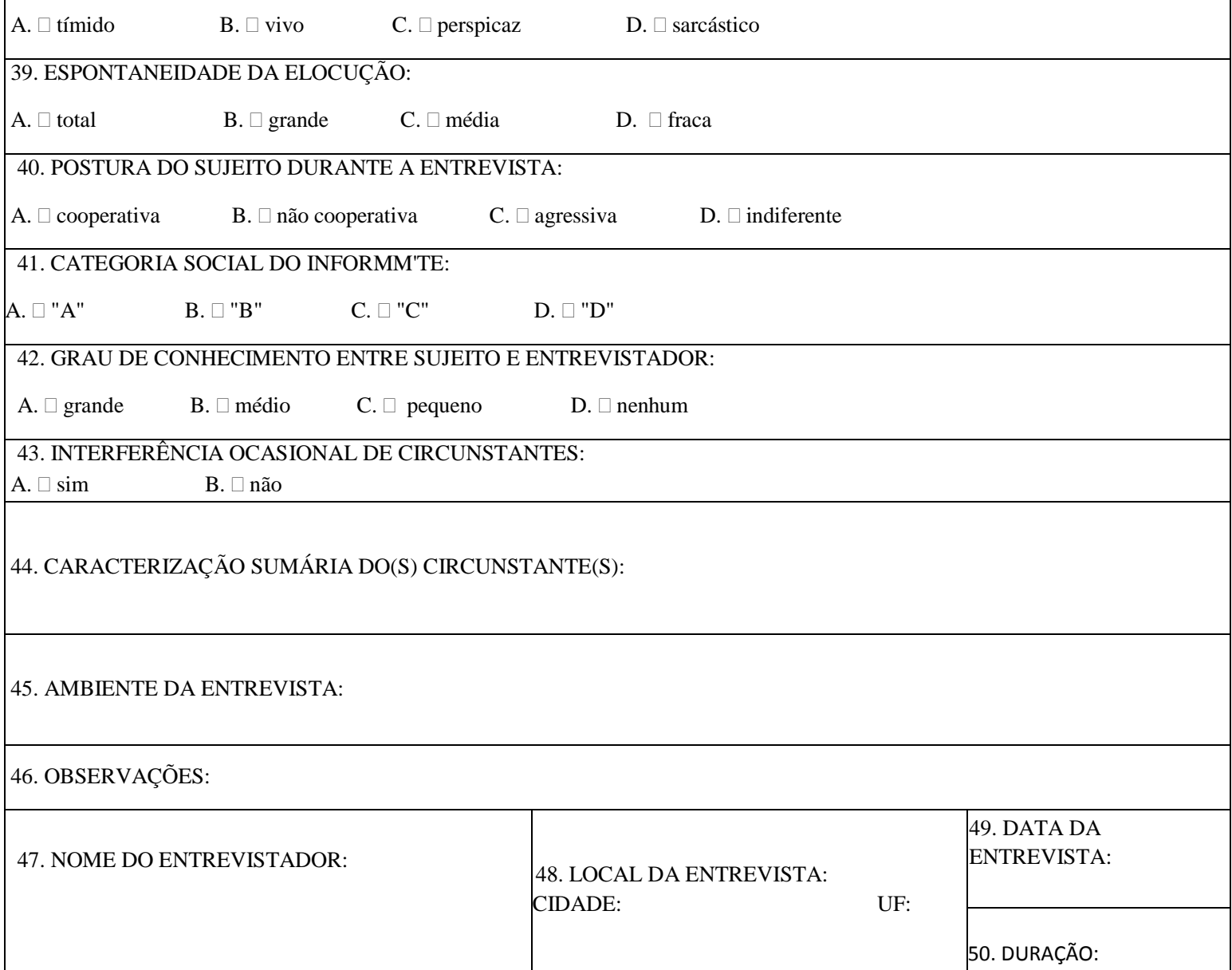




\section{ANEXO C - Pesquisa Complementar}

\section{A. OLHOS}

\section{Ce que les YEUX ne voient pas ne fait pas mal au coeur}

'la vision est le sens par lequel la réalité nous convainc le plus violemment'

mal que se ignora, coração que não chora

o que os olhos não vêem o coração não sente

pena que não se vê não se sente

unminded, unmoaned

what the eye doesn't see, the heart doesn't grieve over

what the eye sees not, the heart rues not

what you don't know won't hurt you

- Cf. o latim medieval quod non videt oculus cor non dolet.

O provérbio tem correspondents em italiano: occhio non mira, cuore non sospira (ou ainda: occhio non vede, cuore non duole) e em espanhol: ojos que no ven, corazón que no siente.

\section{Les YEUX sont le miroir de l'âme}

'les yeux sont un moyen d'expression tellement subtil qu' on y peut deviner des reflets de la richesse de l'âme'

na face e nos olhos se lê a letra do coração

o mal e o bem à face vêm

os olhos são o espelho da alma

the eye is the window of the heart

the eye is the window of the mind

the eyes are the window of the soul

the heart's letter is read in the eyes

- Lê-se em Cícero (De oratore, 3, 59, 221): imago animi vultus, índices oculi (o rosto é a imagem da alma assim como os olhos são os seus delatores). Há provérbio paralelo em italiano: gli occhi sono lo specchio dell'anima (ou ainda: gli occhi sono la spia del cuore). 


\section{B. DENTE}

Do dicionário de provérbios francês-português-inglês, selecionamos os seguintes provérbios:

\section{Oeil pour oeil, DENT pour DENT (1690)}

'la vengeance veut un assouvissement intégral'

espada por espada, lança por lança

olho por olho, dente por dente

an eye for an eye, a tooth for a tooth

tip for tap

tit for tat

Le Hupain de Laon me fit fort grise mine et il oublia - « OUBLI POUR OUBLI, OEIL POUR OEIL ET DENT POUR DENT »- de venir me chercher au lycée trois dimanches de suite. (M. Blacpain, FA, p.65)

O Hupain de Laon me olhou de cara feia e se esqueceu - «esquecimento por esquecimento, OLHO POR OLHO, DENTE POR DENTE » - de vir buscar-me no liceu nos três domingos seguintes.

- A fonte é Êxodo 21, 24 (fórmula da lei de talião): oculum pro óculo, et dentem pro dente. Há equivalentes em italiano: occhio per occhio, dente per dente, em espanhol: ojo por ojo, diente por diente e em alemão: Auge um Auge, Zahn um Zahn. (LACERDA, 2004, p. 346)

\section{Bonnes sont les DENTS qui retiennent la langue (sXVII)}

'il faut se mordre la langue pour se retenir de parler inconsidérément (sinon, on se la mordra pour se repentir d'avoir trop parlé)'

de calar ninguém se arrepende e de falar sempre

não fales mais que a boca

quem mal fala sua língua suja

good that the teeth guard the tongue

the tongue walks where the teeth speed not 


\section{Si vous ne pouvez pas mordre, ne montrez pas les DENTS (s XVII)}

'rien ne sert de menacer si l'on n'a pas les moyens d'agir'

não se ladra se não se pode morder

quem não pode morder não mostra os dentes

quem não puder morder não mostre os dentes

quem não tem pé não dá coice

quem pés não tem coices não promete

if you cannot bite, never show your teeth

kindle not a fire that you cannot extinguish

never bite, unless you make your teeth meet

raise no more devils than you can lay

- Diz-se em espanhol: el que no puede morder, que no enseñe los dientes.

2. Il ne sert à rien de montrer les DENTS lorsqu'on / (quando on) est édenté

$=\mathrm{Si}$ vous ne pouvez pas mordre, ne montrez pas les DENTS

\section{BOCA}

Do dicionário de provérbios francês-português-inglês, selecionamos o seguinte provérbio:

\section{Au RIRE connâit-on le fol et le niais (1568)}

'le rire inopportun trahit l'imbécile'

é freqüente o riso na boca de quem não tem siso

muito riso é sinal de pouco siso

muito riso, pouco siso

onde há muito riso há pouco siso

risinho pronto, miolo chocho

laughter is the hiccup of a fool

too much laughter discovers folly 
- Cf. o monóstico de Menandro: o tolo ri mesmo quando não há do que rir. Cf. também Catulo $(39,15)$, que comenta a respeito de alguém que está sempre a rir: risu inepto res ineptior nulla est (nada mais inoportuno do que o riso inoportuno). Há correspondentes em italiano: i matti si connoscono dal molto ridere, em espanhol: es muy frecuente la risa en la boca del necio e em alemão: an vielem Lachen erkennt man den Narren. (LACERDA, 2004, p. 423) 
ANEXO D - Dados do IBGE

Iguape - SP

\section{Síntese das Informações}

\section{Contagem da População 2007}

Pessoas residentes

\section{habitantes}

\section{Morbidades Hospitalares 2007}

Óbitos hospitalares - Homens

Obitos hospitalares-Homens

Óbitos hospitalares - Mulheres

Óbitos hospitalares - doenças- infecciosas e parasitária

Óbitos hospitalares - causas externas de morbidade e mortalidade

Serviços de Saúde 2005

Estabelecimentos de Saúde total

45 óbitos

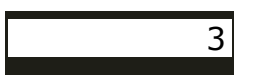

\section{óbitos}

0 óbitos
6

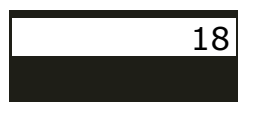

18 leitos

(1)

leitos

Leitos para internação em Estabelecimentos de Saúde público total

Leitos para internação em Estabelecimentos de Saúde total

estabelecimentos

estabelecimentos

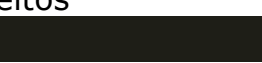

Leitos para internação em Estabelecimentos de Saúde privado total
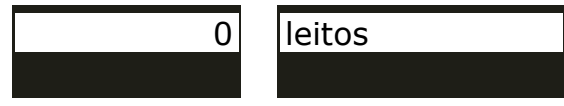

Leitos para internação em Estabelecimentos de Saúde privado SUS

$0 \quad$ leitos

Ensino - matrículas, docentes e rede escolar 2007 


\section{Estatísticas do Registro Civil 2007}

Nascidos vivos - registrados no ano - lugar do registro

Casamentos - registrados no ano - lugar do registro

Separações judiciais - concedidas no ano - em 1a instância - lugar da ação do processo

Divórcios - concedidos no ano - em 1a instância - lugar da ação do processo

\section{Representação Política 2004}

Eleição municipal - Partido do candidato eleito

Eleição municipal - Número de votos do candidato eleito

Eleição municipal - Número de eleitores

Produto Interno Bruto dos Municípios 2006

PIB per capita

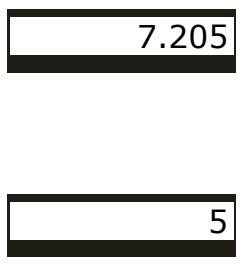

Número de Agências

Finanças Públicas 2006

Valor do Fundo de Participação dos Municípios - FPM

$6.989 .258,95$

Reais

$27.960,48 \quad$ Reais

cias

\section{Estrutura Empresarial 2006}


Indústrias de transformação - Número de unidades locais

Produção e distribuição de eletricidade, gás e água Número de unidades locais

Construção - Número de unidades locais

Base Territorial

Área da unidade territorial
32 unidade

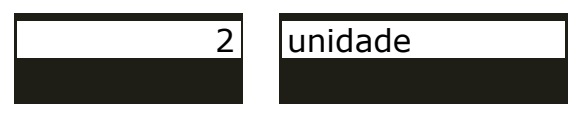

8 unidade

$\mathrm{Km}^{2}$ 